UNIVERSIDADE DE SÃO PAULO

INSTITUTO DE GEOCIÊNCIAS

\title{
HDROGEOQUÍMICA DO GRUPO UNA (BACIAS DE IRECÊ E SALITRE): UM EXEMPLO DA AÇÃO DE ÁCIDO SULFÚRICO NO SISTEMA CÁRSTICO
}

\author{
MURILO ADRADE VALLE
}

Orientador: Prof. Dr. Ivo Karmann

TESE DE DOUTORAMENTO

COMISSÃO JULGADORA

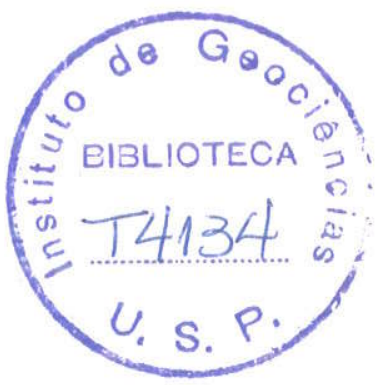

Nome

Presidente: Prof. Dr. Ivo Karmann

Examinadores: Prof. Dr. Joel Barbujiani Sígolo

Prof. Dr. Augusto Sarreiro Auler

Prof. Dr. José Antonio Ferrari

Prof $^{\mathrm{a}}$. Dr ${ }^{\mathrm{a}}$. Vivian Helena Pellizari

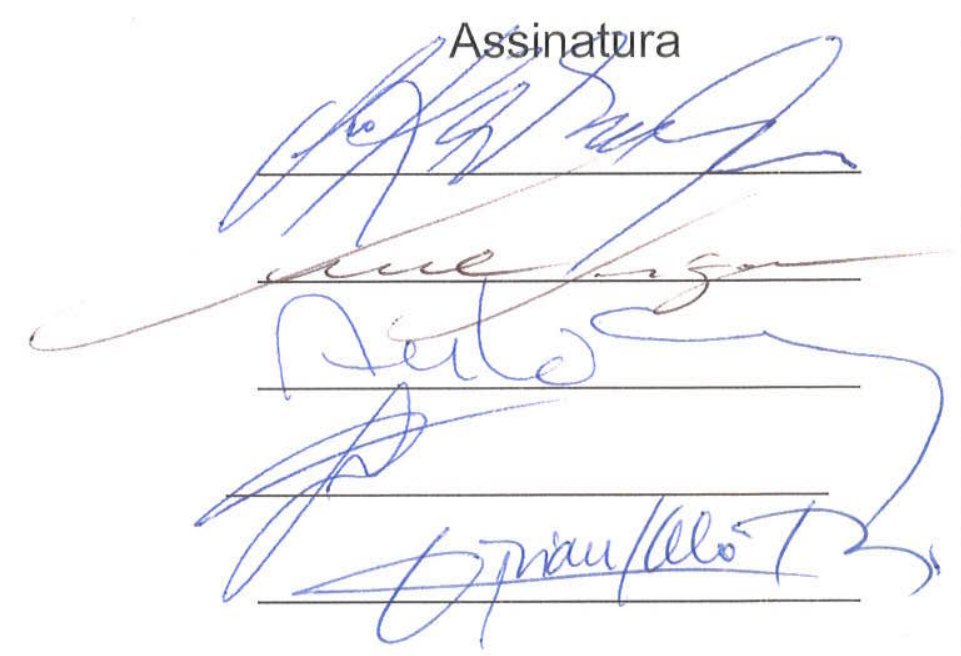

$$
\begin{aligned}
& \text { SÃO PAULO } \\
& 2004
\end{aligned}
$$




\section{UNIVERSIDADE DE SÃO PAULO \\ INSTITUTO DE GEOCIÊNCIAS}

\section{HIDROGEOQUÍMICA DO GRUPO UNA (BACIAS DE IRECÊ E SALITRE): UM EXEMPLO DA AÇÃO DE ÁCIDO SULFÚRICO NO SISTEMA CÁRSTICO}

Murilo Andrade Valle

Orientador: Prof. Dr. Ivo Karmann

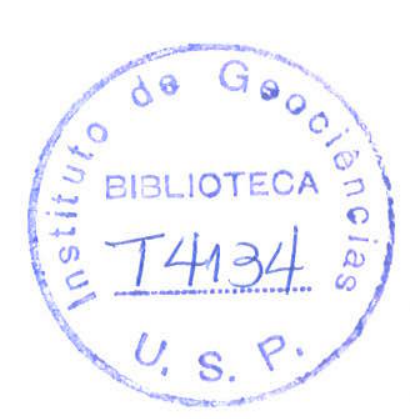

TESE DE DOUTORAMENTO

Programa de Pós-Graduação em Recursos Minerais e Hidrogeologia

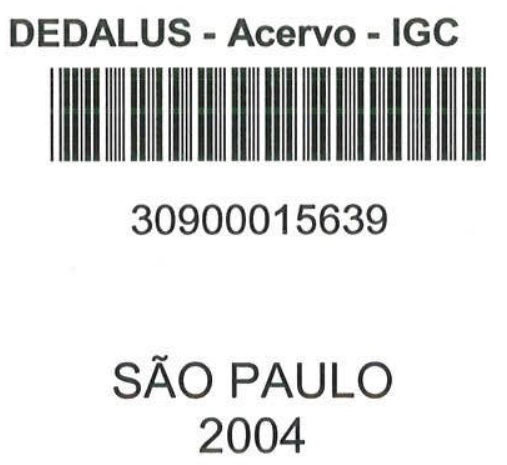


À minha familia e amigos, pelo apoio constante. 


\section{AGRADECIMENTOS}

Ao Prof. Dr. Ivo Karmann pela orientação segura durante a elaboração desta tese e pelo apoio, companheirismo e amizade, condições essenciais para um trabalho em equipe.

Aos colegas William Sallum Filho e Francisco William da Cruz pelos debates, críticas e sugestões sempre valiosas;

Ao amigo Augusto Auler, pelo incentivo e pelas discussões geológicas referentes ao tema da pesquisa.

A prof ${ }^{a}$ Dr $^{a}$ Vivian Helena Pellizari, ICB/USP, por ter aceito o desafio da pesquisa e ter colocado o laboratório de microbiologia, sob sua coordenação, à disposição; a prof ${ }^{a} \mathrm{Dr}^{\mathrm{a}}$ Márcia Xirakawa pelo apoio e incentivo; À Eveline Farias, ICB/USP, pelo apoio em atividades de campo e discussões sobre microbiologia e aos técnicos Marcelo, Rosa e Marcia; À Maira Andrea Costa pelo apoio na discussão de bibliografia relativa à microbiologia.

Ao prof. Dr. José Antonio Ferrari, pelas informações sobre controle hidrológico de sistemas cársticos.

Ao Prof. Dr. Aroldo Misi, pela discussão sobre a origem de sulfetos no Grupo Una.

A Luiz Mancini e Maria Helena, por apoio no Laboratório de Isótopos Estáveis do CEPEGEO/IGc/USP.

A Alexandre Lobo e Rogério Padial pelo suporte prestado em atividades de campo e laboratório; À leda R.P.Valle e Rosangela Rodrigues pelo apoio em atividades de laboratório; À Gisele Martins, Fabiana Dias, Letícia Rocha e Aymoré Cunha, Carlos "Guâno" e Zélio Augusto "Hermann" pelo apoio nos trabalhos de campo.

Aos colegas Heron Dominguez e Hamilton Viana pelas discussões químicas;

À leda R.P. Valle, Cristina Andrade Valle e Daniel Andrade Valle pelo auxilio em trabalhos de formatação.

A Eduardo Figueiredo, família e guias, pelo apoio nas atividades de coleta na Gruta da Torrinha e permissão de instalação de equipamento em sua propriedade; $A$ Admir Brunelli e Ana Malone, pelo apoio em atividades de coleta em Iraquara; $\grave{A}$ Simpliciano Lima e família pelo apoio nas atividades na Gruta Lapa Doce e permissão de instalação de equipamento em sua propriedade; À Raimundo Sólon, Silvio Arruda e Junior, pelo apoio nas atividades no Sistema Gruta Azul-Pratinha e pela permissão de instalação de equipamento em suas propriedades.

À Prefeitura Municipal de Barro Alto, pela cessão de espaço para instalação de equipamento; À Prefeitura de Iraquara por apoio logístico no empréstimo de ferramentas.

À CERB (Companhia de Eng ${ }^{a}$ Rural da Bahia) pela concessão de informações de poços, e em especial ao geólogo Francisco Inácio Negrão pela cessão de informações precisas e discussões sobre a área de trabalho; À Companhia Baiana de Pesquisa Mineral pela cessão de relatórios técnicos.

Ao Sr. José Brusaka, CECAV-CD e equipe, pelo apoio em etapas do trabalho de campo;

A João Regis e família, pelo apoio nas instalações do laboratório de campo e facilidade de hospedagem em Iraquara.

Ao Curso de Pós-Graduação do Instituto de Geociências da Universidade de São Paulo por toda infra-estrutura colocada à disposição. À Ana Paula e Magali, da secretaria de pós-graduação, pelos diversos serviços essenciais prestados e pelo 
apoio. Aos técnicos do IGc/USP: Sandra Andrade (ICP), Maria Inês (ICP) José Paulo (LTA), Lucia Helena (CEPAS), Vasco (CEPEGEO), Flávio Machado(DRX), Paulo Mori (FRX) pelo apoio nas atividades de laboratório. Ao "Argilito", do setor de transportes, pela prestatividade durante saídas de campo.

À Rosa Maria Fontes, Carlos Grandi, Januária Dani, Silvia Mendes e Elaine Pilão pelo suporte em atividades laboratoriais na Fundação Santo André.

Ao Prof. Dr. Marcelo Rocha e Eduardo Jacomassi, pelas discussões sobre métodos estatísticos.

Aos professores Drs. Joel Sígolo e José Antonio Ferrari, pelas contribuições na ocasião do exame de qualificação.

Ao Prof. Dr.Mori e técnicos Sandro e Cristina, do IQ/USP, pela permissão de uso de equipamento.

Ao prof.Dr. Marcelo Moreira, CENA-USP, pela oportunidade e presteza na utilização do Laboratório de Isótopos sob sua coordenação.

Ao Grupo Bambui de Pesquisas Espeleológicas pela cessão de mapas e informações relativas às cavernas da área de estudo.

Aos amigos José Luis e Márcia pelo apoio e incentivo. Aos demais amigos pelo incentivo. Aos meus pais, Francisco e Marly e irmãos, Cristina e Otávio pelo incentivo e apoio constante.

À minha esposa leda Regina Paixão Valle e meus filhos, Luiza e André, pelo apoio, incentivo e paciência constante, sem os quais seria impossivel concluir esta etapa.

À Fundação de Amparo à Pesquisa do Estado de São Paulo - FAPESP, pelo auxílio financeiro do projeto (Processo $n^{\circ}$ 01-09615-0) e a Fundação Santo André, por oferecer condições para a realização da pesquisa.

A todas as pessoas que direta ou indiretamente contribuiram de alguma maneira para que este trabalho pudesse ser realizado. 


\section{SUMÁRIO}

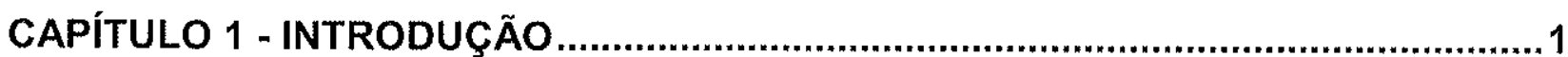

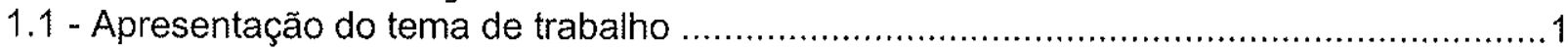

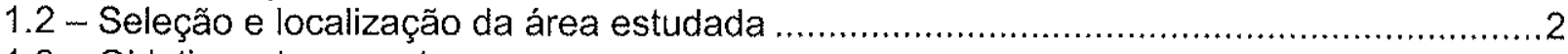

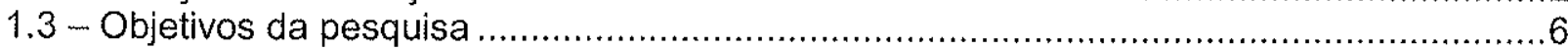

\section{CAPÍTULO 2 - CARACTERÍTICAS GEOLÓGICAS E GEOMORFOLÓGICAS DA ÁREA DE ESTUDO}

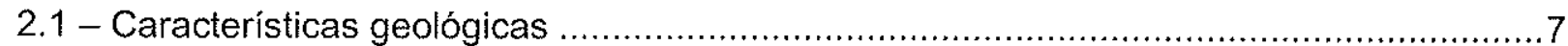

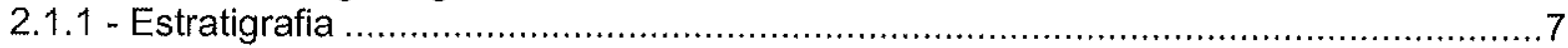

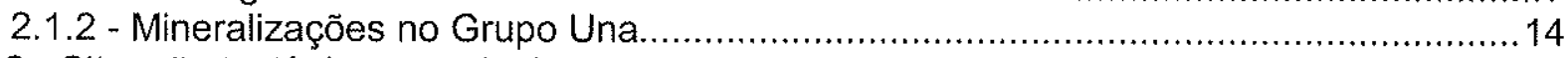

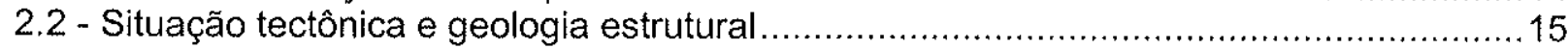

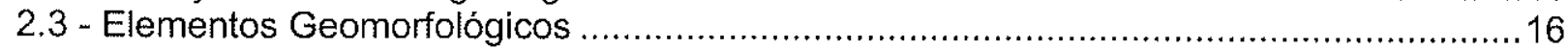

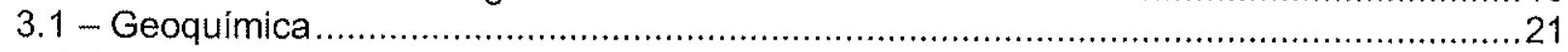

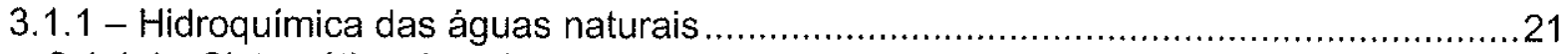

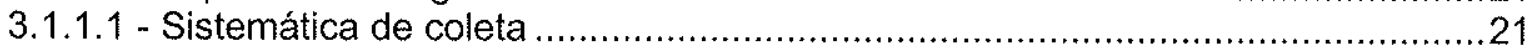

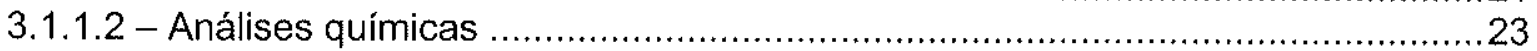

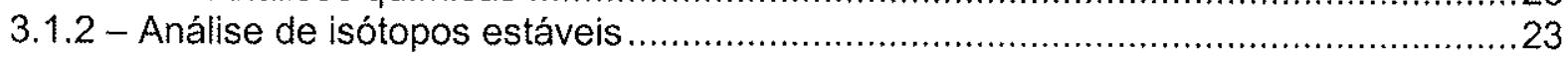

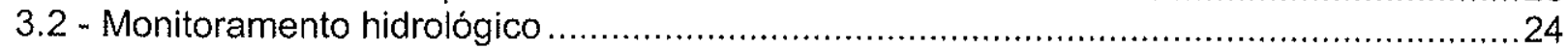

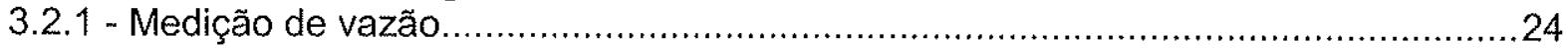

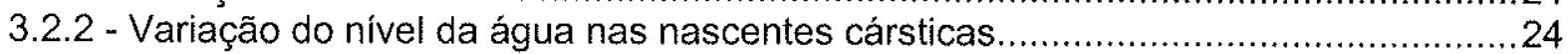

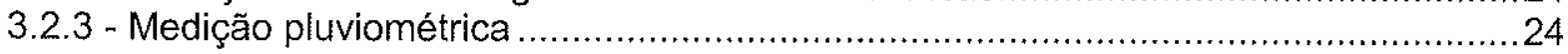

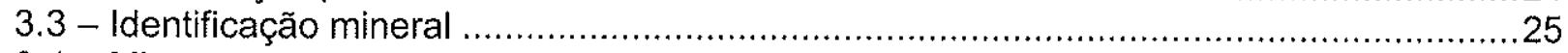

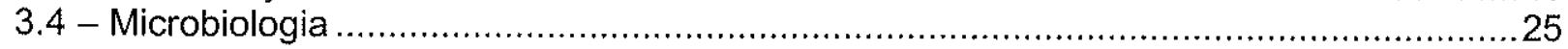

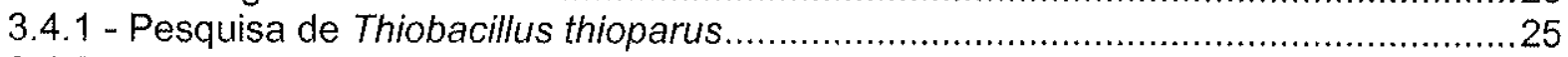

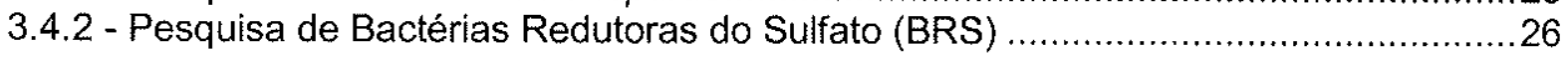

CAPÍTULO 4 - HIDROQUÍMICA DAS ÁGUAS NATURAIS - DINÂMICA ATUAL .....28

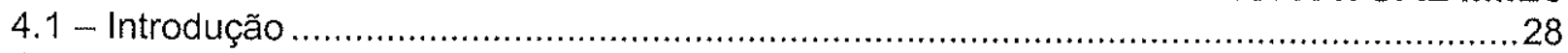

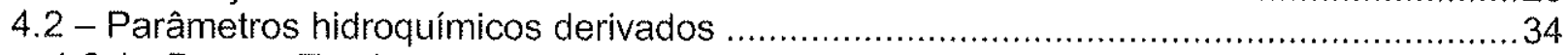

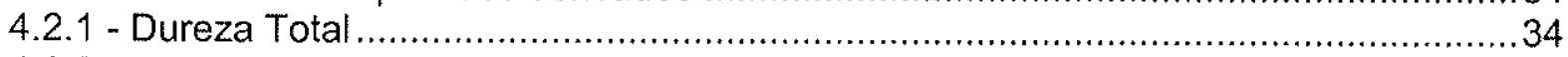

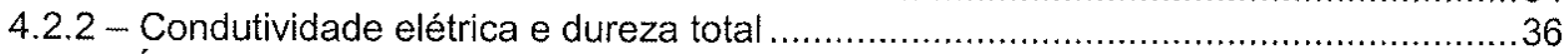

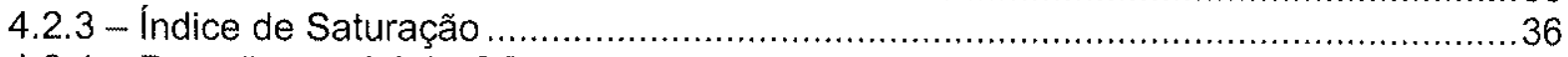

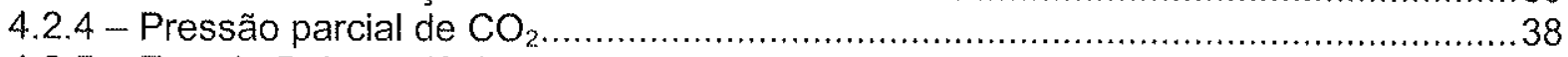

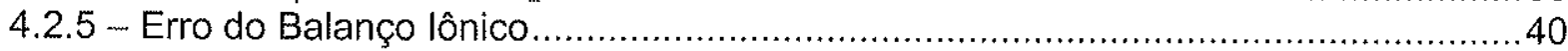

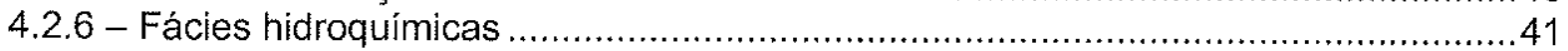

Fácies 1 - escoamento superficial alogênico.....................................................42

Fácies 2 - Fluxo freático profundo não carbonático …….......................................42

Fácies 3 - fluxo freático profundo carbonático ......................................................42

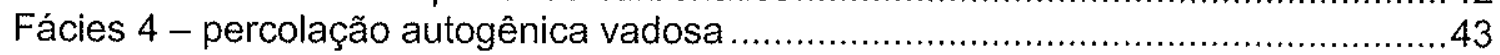

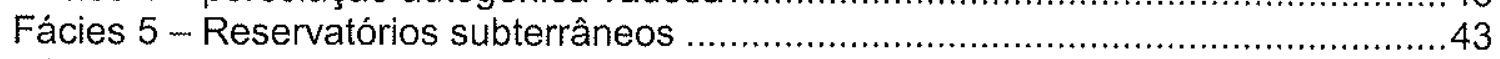

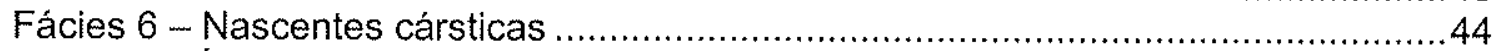

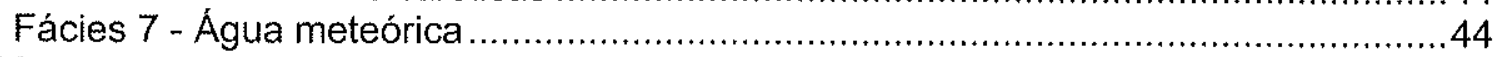

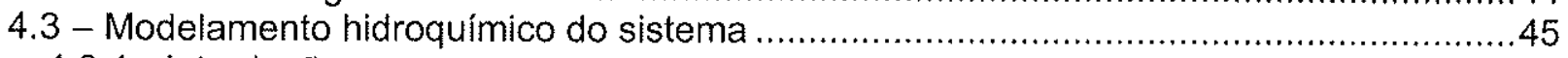

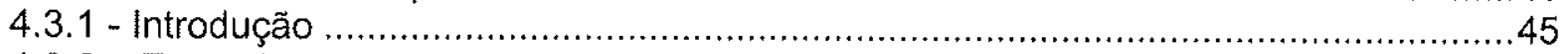

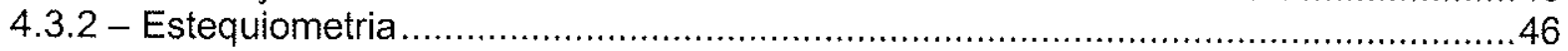

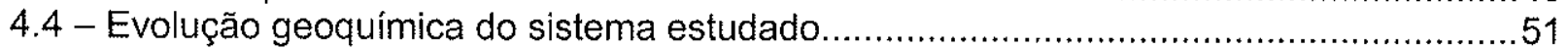

4.5 - Teste do modelo em um sistema cárstico pobre em sulfato ..............................................60 
CAPÍTULO 5 - HIDROLOGIA DO SISTEMA CÁRSTICO ESTUDADO …...................62

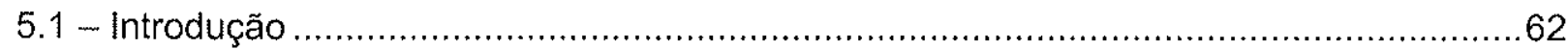

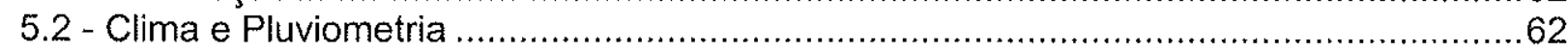

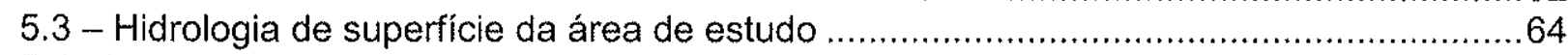

5.4 - Hidrologia subterrânea da área de estudo...............................................................69

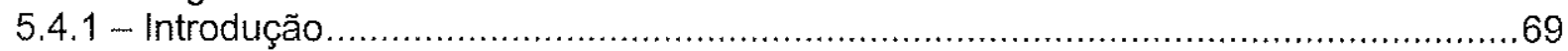

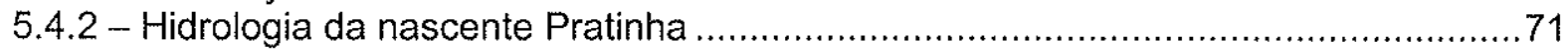

5.4.3 - Hidrologia da nascente do rio Pacui.......................................................................

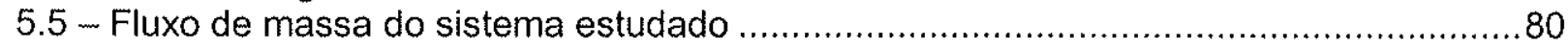

\section{CAPÍTULO 6 - ESPELEOTEMAS DE GIPSITA ASSOCIADOS AO CARSTE DO}

GRUPO UNA

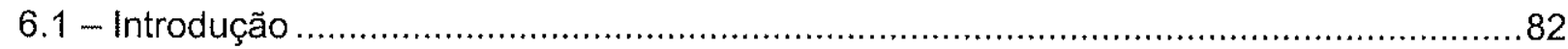

6.2 - Ocorrências de gipsita no ambiente cárstico estudado ............................................83

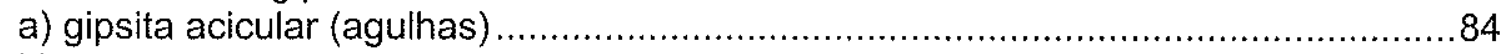

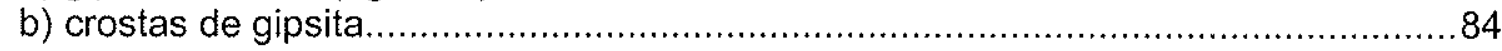

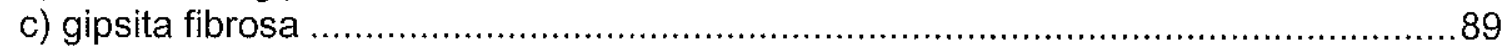

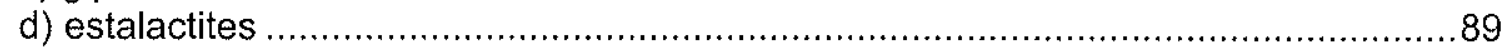

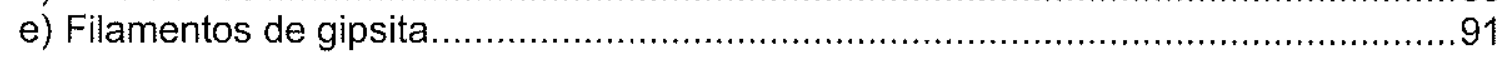

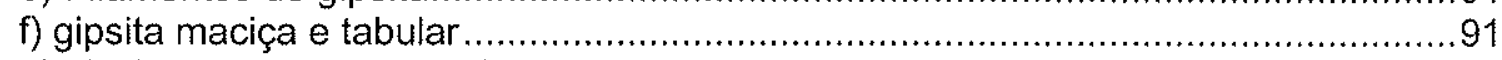

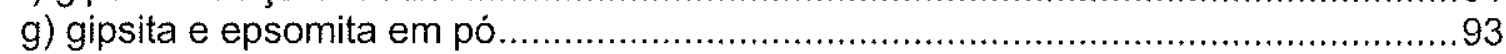

6.3 - Gênese de espeleotemas de gipsita...................................................................

CAPÍTULO 7 - GEOQUÍMICA DOS ISÓTOPOS ESTÁVEIS DE ENXOFRE E

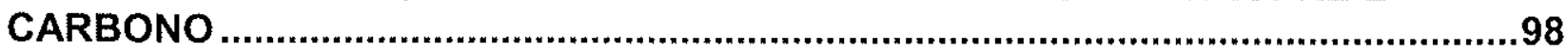

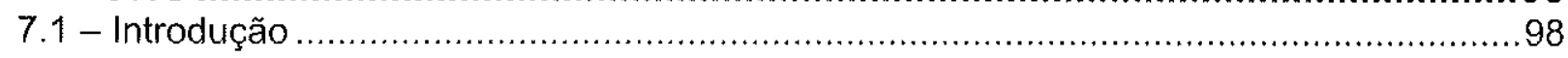

7.2 - Dados isotópicos do carste estudado ........................................................................99

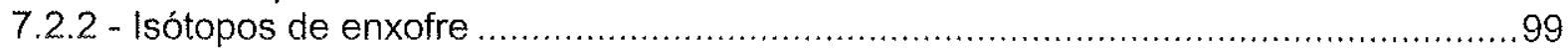

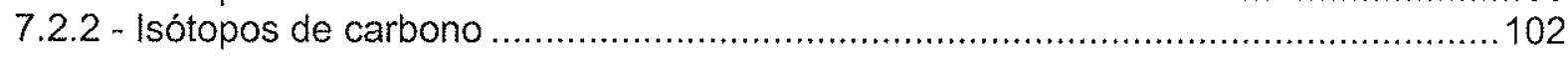

CAPÍTULO 8 - ASPECTOS MICROBIOLÓGICOS DO CARSTE ESTUDADO........... 105

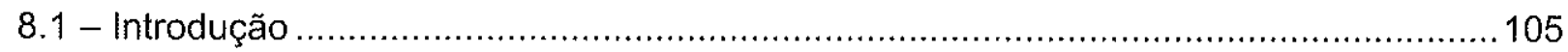

8.2 - Pesquisa de Acithiobacillus ferooxidans ................................................................. 107

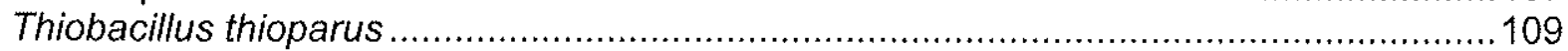

8.3 - Pesquisa de Bactérias Reduroras de Sulfato (BRS) ...............................................109

CAPÍTULO 9 - CONCLUSÕES E CONSIDERAÇÕES FINAIS ...............................112

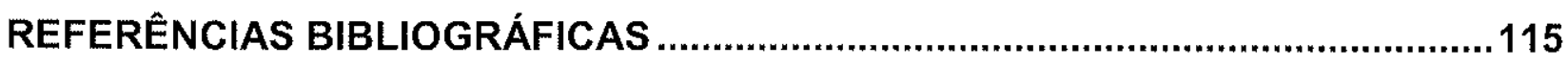




\section{LISTA DE FIGURAS}

Figura 1.1 - Mapa geológico simplificado do estado da Bahia .................................4

Figura 1.2 - Grupo Una no estado da Bahia ................................................... 5

Figura 1.3 - Mapa de localização da área de estudo .............................................. 5

Figura 2.1 - Coluna litoestratigráfica da Formação Bebedouro.................................9

Figura 2.2 - Ciclos de sedimentação - Formação Salitre .................................... 10

Figura 2.3 - Correlações litoestratigráficas entre os Grupos Bambuí e Una...............11

Figura 2.4 - Mapa geológico do Grupo Una - Bahia.........................................12

Figura 2.5- Seção geológica (SW-NE) do Grupo Una na Bacia de Irecê ....................17

Figura 3.1 - Localização dos pontos de coleta (bacia de Irecê) ................................19

Figura 3.2 - Localização dos pontos de coleta (bacia de rio Salitre) .........................20

Figura 3.3 - Coleta de água em gotejamento de estalactites................................22

Figura 4.1 - Esquema dos ambientes de circulação de água .................................29

Figura 4.2 - Relação entre condutividade elétrica e dureza total da amostragem da

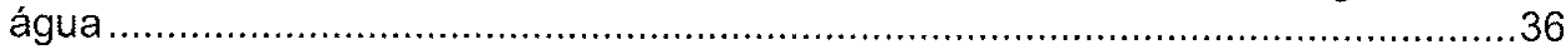

Figura 4.3 - Faixas de erro do balanço iônico.................................................4 41

Figura 4.4 - Índice de Saturação em gipsita x Fácies Hidroquímicas .........................52

Figura 4.5 - Índice de Saturação em dolomita x Fácies Hidroquímicas .....................5 52

Figura 4.6 - Indice de Saturação em Calcita x Fácies Hidroquímicas .........................53

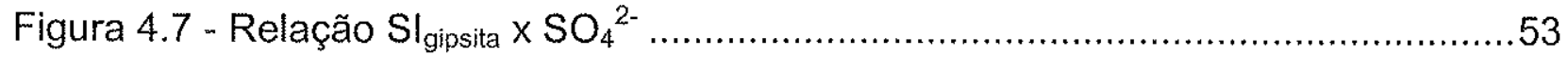

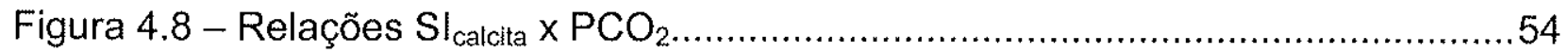

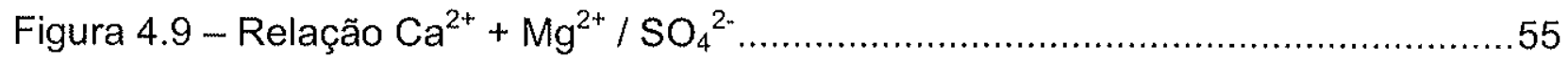

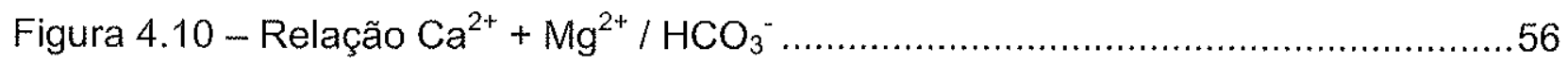

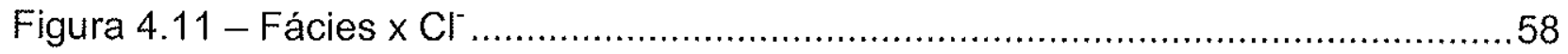

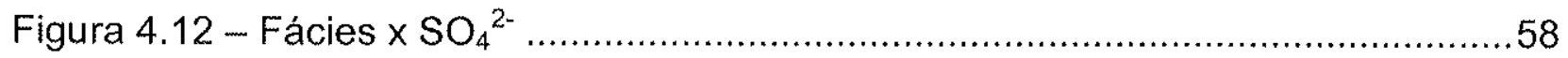

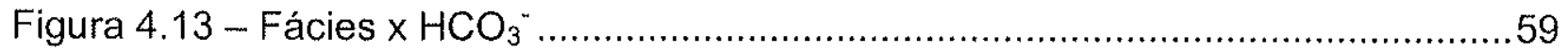

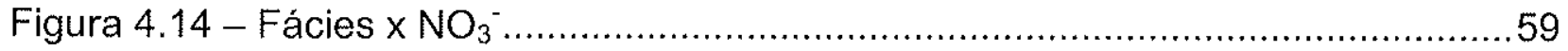

Figura 5.1 - Carta de isoietas Bacia de Irecê - ano base 2003 .............................65

Figura 5.2-Balanço hídrico do município de Iraquara-BA ....................................66

Figura 5.3- Balanço hídrico do município de Brotas do Macaúba-BA........................66

Figura 5.4 - Mapa de isolinhas de P/EP - Bacia de Irecê ....................................67

Figura 5.5 - Balanço Hídrico do município de Iraquara-BA (2003) ...........................68

Figura 5.6 - Mapa potenciométrico da bacia de Irecê.......................................72

Figura 5.7 - Curva Chave para a Nascente da Pratinha .........................................73 
Figura 5.8 -Fluviograma da Nascente da Pratinha - Iraquara-BA

Figura 5.9 - Comparação direta entre variação dos niveis observados na gruta Lapa Doce, Sistema Gruta AzulmPratinha e pluviometria

Figura 5.10 - Correlação cruzada entre reservatório da gruta Lapa Doce e precipitação em Iraquara-BA.

Figura 5.11- Correlação cruzada entre sistema gruta Azul-Pratinha e precipitação em

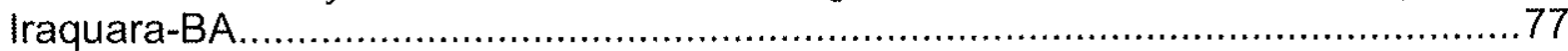

Figura 5.12 - Curva Chave nascente do rio Pacuí ........................................... 78

Figura 5.13-Fluviograma da nascente do Pacuí ........................................... 78

Figura 5.14 - Relação vazão e parâmetros hidroquímicos na resurgência da Pratinha81

Figura 6.1 - Esquema da formação de cristais de gipsita acicular por evaporação ......96

Figura 6.2 - Esquema de formação de minerais de gipsita por capilaridade através do sedimento

Figura 7.1 - Composição isotópica do enxofre em diferentes compartimentos no carste estudado. (*1) - Misi \& Kyle (1994), Kyle \& Misi (1997), Misi \& Veizer (1998) ; ( $\left.{ }^{*} 2\right)$ este estudo ; ( $\left.{ }^{*} 3\right)$ Auler (1999). 101

Figura 7.2 - Composição isotópica do carbono em diferentes compartimentos.... 104 


\section{LISTA DE TABELAS}

Tabela 4.1 - Resultados analíticos e parâmetros hidroquímicos derivados das fácies

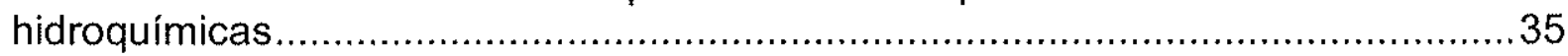

Tabela 4.2 - Índice de saturação nas fácies hidroquímicas ..................................39

Tabela 4.3 - Parâmetros hidroquímicos das águas de chuvas na bacia de Irecê........44

Tabela 4.4 - Razões estequiométricas entre as fácies hidroquímicas e a reação de dissolução de rocha carbonática (calcário) por ácido carbônico ...........................48

Tabela 4.5 - Razões estequiométricas entre as fácies hidroquímicas e a reação de dissolução de rocha carbonática (dolomito) por ácido carbônico..

Tabela 4.6 - Razões molares entre os valores médios de $\mathrm{Ca}^{2+}+\mathrm{Mg}^{2+} / \mathrm{HCO}_{3}{ }^{2}$ nas fácies hidroquímicas

Tabela 4.7 - Razões molares entre os valores médios de $\mathrm{Ca}^{2+}+\mathrm{Mg}^{2+} / \mathrm{SO}_{4}{ }^{2-}$ nas fácies

Tabela 4.8- Razões molares entre $\mathrm{Ca}^{2+}+\mathrm{Mg}^{2+} / \mathrm{HCO}_{3}^{-}$em dados secundários

Tabela 5.1 - Dados básicos para construção da curva chave - Nascente da Pratinha 73

Tabela 5.2 - Parâmetros hidrológicos da nascente da Pratinha 74

Tabela 5.3 - Dados básicos para construção da curva chave para a nascente do Pacuí

Tabela 5.4 - Parâmetros hidrológicos da nascente do Pacuí .79

Tabela 7.1 - Dados isotópicos de sulfatos e sulfetos - Grupo Una 100 ocorrência. 100

Tabela 7.2 - Dados isotópicos de rocha carbonática e de carbonato precipitado de água subterrânea.

Tabela 8.1. Resultados finais da Presença (P) ou Ausência $(A)$ das bactérias oxidantes (Thiobacillus thioparus e Acithiobacillus ferooxidans) em amostras de rochas e sedimentos.

Tabela 8.2 - pH da amostra e do meio de cultura de Postgate modificado para T.thioparus. 


\section{LISTA DE QUADROS}

Quadro 2.1 - Unidades informais de fácies da Formação Salitre...............................13

Quadro 3.1 - Quadro síntese das atividades analíticas ..........................................18

Quadro 3.2 - Meios de cultura utilizados para determinação de espécies de Thiobacillus

Q

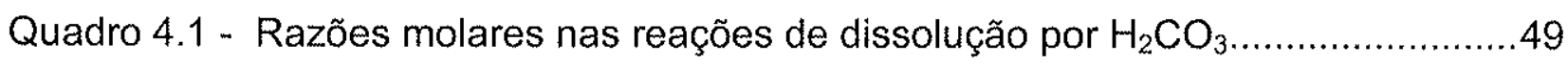

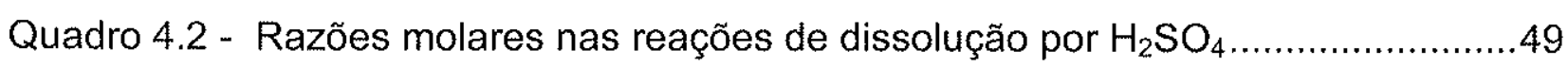

Quadro 4.3 - Razões molares nas reações de dissolução por $\mathrm{H}_{2} \mathrm{SO}_{4}$ e $\mathrm{H}_{2} \mathrm{CO}_{3} \ldots \ldots \ldots . . . .49$

Quadro 5.1 - Déficit hídrico dos municípios da bacia de Irecê....................................63

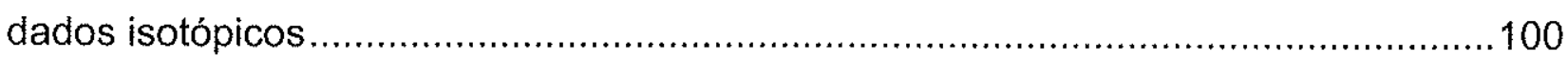




\section{LISTA DE FOTOS}

Foto 4.1 - Nascente alogênica no Povoado de Sonhem - Iraquara-BA ......................30

Foto 4.2 - Percolação vadosa - gotejamento ativo - Gruta Torrinha.............................31

Foto 4.3 - Reservatório subterrâneo na Toca do Pitú - Campo Formoso/BA................32

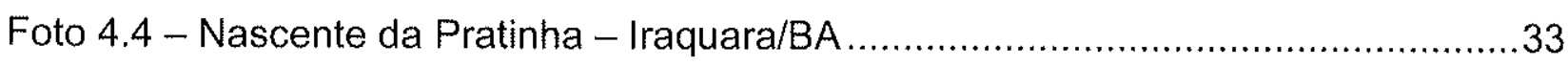

Foto 4.5 - Nascente do Pacuí - Campo Formoso/BA .................................................... 33

Foto 4.6 - Nascente do Rio Pacuí - Campo Formoso/BA …….......................................34

Foto 6.1 - Agulhas formadas junto às gretas de contração, Gruta Torrinha ..................85

Foto 6.2 - Agulhas de gipsita sobre sedimentos clásticos, gruta Torrinha....................86

Foto 6.4 - Feições de corrosão na rocha (pendants) recobertos por crosta de gipsita. 86

Foto 6.3 - Blocos abatidos e espeleotemas carbonáticos recobertos por crosta de

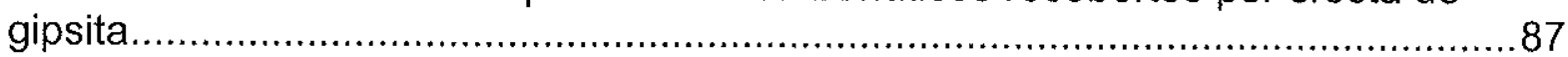

Foto 6.5 - Sedimentos clásticos sobrepostos a crosta de gipsita .................................8

Foto 6.6 - Crosta de gipsita cristalina com cristais milimétricos em manchas irregulares, Gruta Torrinha.

Foto 6.7 - Gipsita fibrosa associada a juntas de estratificação e crostas de gipsita na parede.

Foto 6.8 -Estalactite de gipsita na extremidade de estalactites carbonáticas .90

Foto 6.9 - Conjunto de espeleotemas carbonáticos (tipo cortina) com feições de corrosão e deposição de gipsita na forma de estalactites e crostas.

Foto 6.10 - Filamentos de gipsita formados por exsudação

Foto 6.11 - Desplacamento de teto por expansão de crescimento de gipsita na gruta Didi. No piso observam as lascas e blocos oriundos do teto

Foto 6.12 - Desplacamento de parede por expansão de crescimento de gipsita em planos de estratificação da rocha na gruta Santa Marta. Nota-se o acúmulo das lascas de rocha carbonática junto à parede alterada

Foto 6.13 - Espeleotema quebrado pela expansão de crescimento de gipsita. 


\title{
LISTA DE SIGLAS / ABREVIAÇÕES
}

\author{
Sigla significado \\ BRS Bactérias Redutoras de Sulfato \\ CBPM Companhia Baiana de Pesquisa Mineral \\ CDT Cânion do Diablo Troilite \\ CERB Companhia de Engenharia Rural da Bahia \\ EP Evapotranspiração Potencial \\ ICB/USP Instituto de Ciências Biomédicas da Universidade de São Paulo \\ IGc/USP Instituto de Geociências da Universidade de São Paulo \\ INPE/CPTEC Centro de Previsão de Tempo e Estudos Climáticos do Instituto Nacional de \\ Pesquisas Espaciais \\ NMP Número mais provável \\ OMM Organização Mundial de Meteorologia \\ $\mathrm{P} \quad$ Precipitação (água meteórica) \\ PDB-V Pee Dee Belemnite - Vienna \\ ppt Precipitado químico \\ SI Indice de Saturação (Saturation Index) \\ SUDENE Superintendência do Desenvolvimento do Nordeste \\ UFBA Universidade Federal da Bahia
}




\section{Resumo}

O presente estudo investigou a participação do $\mathrm{H}_{2} \mathrm{SO} 4$, como agente corrosivo no carste do Grupo Una, na bacia de Irecê e na bacia do rio Salitre, tendo como base o monitoramento hidroquímico e a determinação de fácies hidroquímicas. A fácies escoamento superficial alogênico é caracterizada por baixos valores de $\mathrm{pH}(\overline{\mathrm{X}}=4,79 ; \mathrm{CV}=3,15 \%)$ e dos principais cátions e ânions, com destaque para $\mathrm{SO}_{4}{ }^{2-} \quad(x=0,57 \mathrm{mg} / \mathrm{L} ; \mathrm{CV} 10,32 \%) ;$ A fácies fluxo freático profundo carbonático representa a maior concentração de $\mathrm{HCO}_{3}{ }^{\circ}$ de todo conjunto amostrado, com média igual a $359,08 \mathrm{mg} / \mathrm{L}$. Na média as águas desta fácies encontram-se saturadas para calcita $\left(S I_{c}=0,02\right)$ e insaturadas para gipsita $\left(\mathrm{Sl}_{\mathfrak{g}}=-1,51\right)$. A concentração de $\mathrm{SO}_{4}{ }^{2-}$ também é alta $(\overline{\mathrm{X}}=204,50 \mathrm{mg} / \mathrm{L}$; CV $135,00 \%)$, destacando-se um ponto de amostragem que exibe elevado valor médio para $\mathrm{SO}_{4}{ }^{2-} \quad(\bar{X}=746,07 ; \mathrm{CV}=13,79 \%)$; Na fácies percolaçăo vadosa a concentração de $\mathrm{SO}_{4}{ }^{2-}$ é expressiva, com média igual a $305,09 \mathrm{mg} / \mathrm{L}$; Nos reservatórios subterrâneos destaca-se a alta concentração de $\mathrm{HCO}_{3}{ }^{*}$ (média - 305,10 $\mathrm{mg} / \mathrm{L}$ ), Índice de Saturação para calcita muito próximo do equilibrio $\left(\mathrm{SI}_{\mathrm{C}}=-0,02\right)$ e concentração média para $\mathrm{SO}_{4}{ }^{2-}(\overline{\mathrm{x}}=17,79 \mathrm{mg} / \mathrm{L} ; \mathrm{CV}=$ $52,03 \%)$; Nas nascentes cársticas observou-se alto teor de $\mathrm{HCO}_{3}{ }^{\prime \prime}(\overline{\mathrm{X}}=246,96$ $\mathrm{mg} / \mathrm{L} ; \mathrm{CV}=11,0 \%), \mathrm{SI}_{\mathrm{c}}=0,00(0,28$ a $-0,37)$, em equilíbrio de saturação para o mineral calcita e concentração de $\mathrm{SO}_{4}{ }^{2-}(\overline{\mathrm{x}}=19,30 \mathrm{mg} / \mathrm{L} ; \mathrm{CV}=31,47 \%)$. As águas meteóricas são caracterizadas por baixas concentrações dos principais cátions e ânions, com médias inferiores a $0,5 \mathrm{mg} / \mathrm{L}$.

Cálculos estequiométricos foram aplicados aos dados hidroquímicos e conclui-se que no balanço molar as águas não seguem as razões clássicas para dissolução exclusiva por ácido carbônico, mas sim, adequam-se ao sistema $\mathrm{H}_{2} \mathrm{SO}_{4}-\mathrm{CaMgCO}_{3}$. Minerais secundários de cavernas foram analisados e detectou-se ocorrências expressivas de gipsita, sob a forma de crostas, estalactites e filamentos, que, vinculadas ao ambiente de formação, indicam a participação de soluçōes ricas em sulfato em seus processos. O evento principal de deposição de gipsita foi associado ao rebaixamento do NA após fase de ampliação paragenética dos condutos. Análises isotópicas de $\delta^{13} \mathrm{CHCO}_{3}^{-} \mathrm{em}$ amostras de águas subterrâneas indicam valores enriquecidos $(-10,4 \%$ PDB-V) em relação ao esperado para a reaçăo de dissolução da rocha carbonática por ácido carbônico $(-17,1 \%$ ), condição relacionada à influência de

${ }^{13} \mathrm{C}$ oriundo da rocha por ação do ácido sulfúrico. $0 \delta^{34} \mathrm{~S}$ de sulfato em água subterrânea ( $\bar{x}=17,7 \%$ CDT) é levemente empobrecido em relação à pirita $(\bar{x}=21,3 \%$ ) , com valores na faixa de amplitude prevista para o processo de oxidação, condição que atesta a participação de ácido sulfúrico na dissolução da rocha carbonática. Análises microbiológicas na água subterrânea do aqüífero cárstico indicaram a presença de bactérias do gênero Acidithiobacillus e bactérias redutoras de sulfato (BRS), ambas presentes no ciclo do enxofre e responsáveis pela produção de ácido sulfúrico. Neste sentido, as variáveis estudadas possibilitam a confirmação da participação do ácido sulfúrico na dinâmica do sistema cárstico do Grupo Una no Estado da Bahia.

Palavras chave: carste, hidroquímica, ácido sulfúrico, gipsita, Acidithiobacillus 


\section{Abstract}

The main goal of this study is to determine the effectiveness of sulfuric acid as a corrosive agent in the karst system of the Una Group (Irecê geological basin and Salitre river basin), based on hydrochemical monitoring and the respective hydrochemical facies. The allogenic surface runoff is characterized by low ion concentrations and $\mathrm{pH}(\mathrm{ph}=4,79 ; \mathrm{CV}=3,15 \%)$. Sulfate is also low for this facies $(\widetilde{x}=0,57 \mathrm{mg} / \mathrm{L} ; \mathrm{CV} 10,32 \%)$. With respect to the $\mathrm{HCO}_{3}{ }^{-}$content, the deep phreatic flux in the carbonate aquifer has the highest concentration compared to the other facies, with a mean of $359,08 \mathrm{mg} / \mathrm{L}$. This deep phreatic flux is saturated with respect to calcite and undersaturated with respect to gypsum, showing average concentrations of $204,5 \mathrm{mg} / \mathrm{L}$ (CV 135,00\%) for $\mathrm{SO}_{4}{ }^{2-}$, including one sampling site with average concentration of $746,07 \mathrm{mg} / \mathrm{L}$ (CV $=13,79 \%)$. Expressive sulfate concentration was also detected in the vadose seepage, with a mean of $305,09 \mathrm{mg} / \mathrm{L}$. Underground reservoirs have high $\mathrm{HCO}_{3}{ }^{-}$content $(\overline{\mathrm{x}}=305,10 \mathrm{mg} / \mathrm{L})$ together with calcite saturation index close to equilibrium $\left(\mathrm{SI}_{\mathrm{C}}=-0,02\right)$ and lower sulfate concentration (mean of $17,79 \mathrm{mg} / \mathrm{L}$; $\mathrm{CV}=52.03 \%$ ). The karst springs revealed similar chemistry to the underground reservoirs, with high $\mathrm{HCO}_{3}{ }^{-}$content ( $\overline{\mathrm{x}}=246,96 \mathrm{mg} / \mathrm{L} ; \mathrm{CV}=11,0 \%$ ), saturated with respect to calcite (mean of $\mathrm{SI}_{\mathrm{C}}=0,00$; varying between 0,28 and $-0,37$ ) and mean sulfate concentration of $19,30 \mathrm{mg} / \mathrm{L} \quad(\mathrm{CV}=31.47 \%)$. The meteoric recharge has a very low solute load, with means of all ions lower than $0.5 \mathrm{mg} / \mathrm{L}$. Stoichiometric balance calculations applied to the hydrochemical results showed that the molar balances of the various water facies do not follow the classical ratios of carbonate dissolution only due to carbonic acid, but on the contrary, they follow better the chemical system of $\mathrm{H}_{2} \mathrm{SO}_{4}-\mathrm{CaMgCO}_{3}$. The study of the expressive secondary gypsum deposits in caves, represented by crusts, stalactites and filaments, showed that their origin is related to the deep phreatic water and that the major deposition event of these deposits occurred during the water table lowering after the high water table period related to the paragenetic conduit enlargement. Isotopic composition of dissolved inorganic carbon in groundwater samples showed values of $\delta^{13} \mathrm{CHCO}_{3}{ }^{-}$around $-10,4 \%$ PDB-V, which are relatively enriched with respect to the predicted $\delta^{13} \mathrm{CHCO}_{3}{ }^{-}$of $-17,1 \%$, if the system would be affected only by carbonic acid. This enrichment is attributed to the ${ }^{13} \mathrm{C}$ originated by the reaction between carbonate rock and sulfuric acid. The $\delta^{34} S$ of sulfate in water $(\bar{x}=17,7 \%$ CDT $)$ is slightly depleted than that of pyrite disseminated in carbonate rock $(\bar{x}=21,3 \%)$, but still in the range predicted for the fractionation due to pyrite oxidation, indicating that carbonate rock is dissolved by sulfuric acid.

Microbiological analysis of groundwater in the karstic aquifer revealed the presence of bacteria of the genera Acidithiobacillus and sulfate reducing bacteria (SRB). Both are typical of the sulfur cycle and produce sulfuric acid. Finally, it can be stated, based on the above described results, that sulfuric acid is an important agent in the dynamics of the studied karst.

key-words: karst, sulfuric acid, gypsum, Acidithiobacillus 


\section{CAPITTULO 1 - INTRODUÇÃO}

\section{1 - Apresentação do tema de trabalho}

O carste representa terrenos onde a drenagem é tipicamente subterrânea, e é caracterizado pela presença de feições e paisagens típicas, resultantes de interações de processos de dissolução que as rochas sofrem promovidos por águas subterrâneas e superficiais. As rochas carbonáticas, principais hospedeiras das paisagens cársticas e dos sistemas de cavernas, ocupam cerca de $12 \%$ das áreas continentais sem cobertura glacial, e somente cerca de 7 a $10 \%$ apresentam relevo cárstico. Segundo Ford e Williams (1989), cerca de $25 \%$ da população depende de água extraída do carste.

Terrenos cársticos caracterizam-se também por abrigar aqüiferos de condutos, notáveis pelo fluxo rápido da água subterrânea, baixa capacidade de filtração de material em suspensão e/ou impurezas, alta capacidade de armazenamento de água subterrânea e bacias de drenagem de superfície sem correspondência exata com os sistemas de drenagem subterrânea (Palmer, 1991), características hidrológicas estas diretamente vinculadas aos fatores geológicos (Bögli, 1980). No processo de carstificação, as rochas carbonáticas, sobretudo os calcários e dolomitos em função da alta solubilidade, sofrem reações de dissolução, que são promovidas principalmente pelo ácido carbônico, devido à disponibilidade global de $\mathrm{CO}_{2}$ no solo e atmosfera. No entanto, vale destacar que inúmeros estudos norte americanos e europeus (Hill, 1987; Forti, 1988; Ball \& Jones, 1990; Hill, 1990; Whorthington, 1991; Bischoff et al, 1994; Worthington \& Ford, 1995; Hose et al, 2000) demonstram que a ação de ácido sulfúrico na espeleogênese, em alguns casos é a reação mais importante do desenvolvimento de sistemas de cavernas, e, muitas vezes, produzem feições morfológicas típicas.

A origem do ácido sulfúrico na água pode ser explicada a partir de dois mecanismos: (1) oxidação de $\mathrm{H}_{2} \mathrm{~S}$ (sulfeto de hidrogênio). $\mathrm{O} \mathrm{H}_{2} \mathrm{~S}$ pode ser produzido por reações biogênicas na transformação de matéria orgânica, como também, estar associado a hidrocarbonetos (Davis, 1980; apud Hill, 1987); (2) oxidação de sulfetos.

Hill (1987), em estudo realizado em cavernas das montanhas Guadalupe (EUA), propôs que $\mathrm{H}_{2} \mathrm{~S}$, componente do gás natural gerado juntamente com petróleo em bacias sedimentares, migra posteriormente para o calcário. Afirma que, através da 
oxidação do gás, devido ao contato com a água subterrânea, forma-se $\mathrm{H}_{2} \mathrm{SO}_{4}$, e, posteriormente, $\mathrm{CaSO}_{4}$ e $\mathrm{CO}_{2}$ após interação com a rocha. Estas reações, segundo a autora, explicam a gênese de grandes depósitos secundários de $\mathrm{CaSO}_{4}$ na Caverna Carlsbad (EUA). Egemeier (1981) propôs similar reação, na caverna Kane (EUA), associando a deposição de sulfato a ação de águas termais. Amparando-se na composição isotópica de O e S, Van Everdingen et al (1987), concluíram que as reações de oxi-redução de espécies sulfúricas, com influência microbiológica, em águas termais que depositam travertinos em cavernas do Canadá, produzem espécies de S com subseqüente re-oxidação do ácido sulfúrico com considerável fracionamento de oxigênio e seus isótopos resultantes. Yonge \& Krouse (1987), através de análise isotópica de S em minerais da caverna Castleguard - Canadá, concluíram que pirita, disseminada na rocha matriz, é a possivel fonte para a grande quantidade de gipsita encontrada. Krothe \& Libra (1983), concluíram que a atividade microbiana tem forte implicação no fracionamento dos isótopos de $\mathrm{S}$ na fase freática dos aqüíferos cársticos em Indiana-EUA. Morehouse (1968), principal precursor da idéia, propôs que as reações de $\mathrm{H}_{2} \mathrm{SO}_{4}$ na gênese de algumas cavernas, têm como base, as interações entre água e dolomitos que contém galena, ao estudar cavidades desenvolvidas no contato entre calcários e sulfetos de corpos de minérios, na caverna Level Crevice (EUA). Worthington (1991), estudando a hidrogeologia cárstica das montanhas rochosas canadenses, salienta a importância da circulação profunda de águas, associada à remoção de enxofre, procedente de gipso e/ou pirita, indicando que o ácido sulfúrico pode, dependendo das circunstâncias, ser mais efetivo que o ácido carbônico no processo inicial de espeleogênese. O presente estudo destaca a ocorrência de ácido sulfúrico, amparado principalmente em informações hidroquímicas, microbiológicas e de ocorrências minerais em cavernas, como agente corrosivo no carste do Grupo Una.

\section{2 - Seleção e localização da área estudada}

Poucos trabalhos foram desenvolvidos sobre a hidroquímica do carste brasileiro, destacando-se Karmann (1994), que investigou o carste do Alto Ribeira (SP), atribuindo sua origem essencialmente à ação do ácido carbônico e Guerra (1986) que investigou características hidroquímicas do carste do Grupo Bambuí na Bahia, não tratando da 
gênese do aqüífero de condutos. Auler (1996; 1999) levanta a hipótese de dois tipos de agentes de dissolução para o carste do Grupo Una, o tradicional ácido carbônico e o ácido sulfúrico, porém, baseado em dados hidroquímicos secundários.

De acordo com a regionalização de terrenos cársticos do Brasil efetuada por Karmann e Sánchez (1979), evidencia-se potencial espeleológico para as coberturas carbonáticas plataformais dos Grupos Bambui e Una (figura 1.1), no Brasil central (GO, $M G, B A$ ), os metacalcários e dolomitos na Serra da Bodoquena (MS) e seqüência carbonática do Grupo Araras (MT) e os metacalcários e metadolomitos do Grupo Açungui, na região sudeste (SP, PR). Dentre estas áreas, e considerando os objetivos da pesquisa, foi escolhido o sistema cárstico associado ao Grupo Una (figura 1.2), tendo em vista que:

- dados de Guerra (1986) e CERB (2002), mostram no aqüifero cárstico do Grupo Una uma tendência regional de teores em ânions sulfato, com valores superiores aos normalmente anotados em terrenos cársticos onde predominam íons relacionados ao sistema $\mathrm{H}_{2} \mathrm{O}-\mathrm{CO}_{2}-\mathrm{CaCO}_{3}$;

- informações contidas em relatórios técnicos da CBPM (1998) (Cia Baiana de Pesquisa Mineral) e em Misi \& Souto (1975) e Misi (1979), indicam altos teores e percentuais de minérios de enxofre em rochas do Grupo Una;

- abrigam importantes sistemas de cavernas, dentre os quais, as duas maiores cavernas do Brasil, Toca da Boa Vista $(108 \mathrm{~km})$ e Toca da Barriguda (30km) (Rubbioli, inf.verbal) e várias outras com extensões superiores a $5 \mathrm{~km}$ de projeção horizontal;

- em inúmeras cavernas da área citada observam-se quantidades expressivas de depósitos secundários de minerais de sulfato, com destaque para agulhas de gipsita.

O entendimento dos processos químicos envolvidos na evolução do carste do Grupo Una ultrapassa a explicação da gênese de cavernas, pois a geração de porosidade em niveis freáticos profundos pode trazer uma contribuição importante ao entendimento do aqüífero e sua dinâmica, pontos básicos para subsidiar a avaliação de volume, distribuição e qualidade da água subterrânea em terrenos cársticos.

A área de estudo localiza-se no setor central e centro-norte do estado da Bahia (figura 1.3), abrangendo parte dos municípios de Campo Formoso, Iraquara, Canarana, Barro Alto, Mulungú do Morro, Lapão e Irecê. 


\section{FiguRA 1.1 - MAPA GEOLÓgICO SIMPLIFICADO DO ESTADO DA BAHIA}

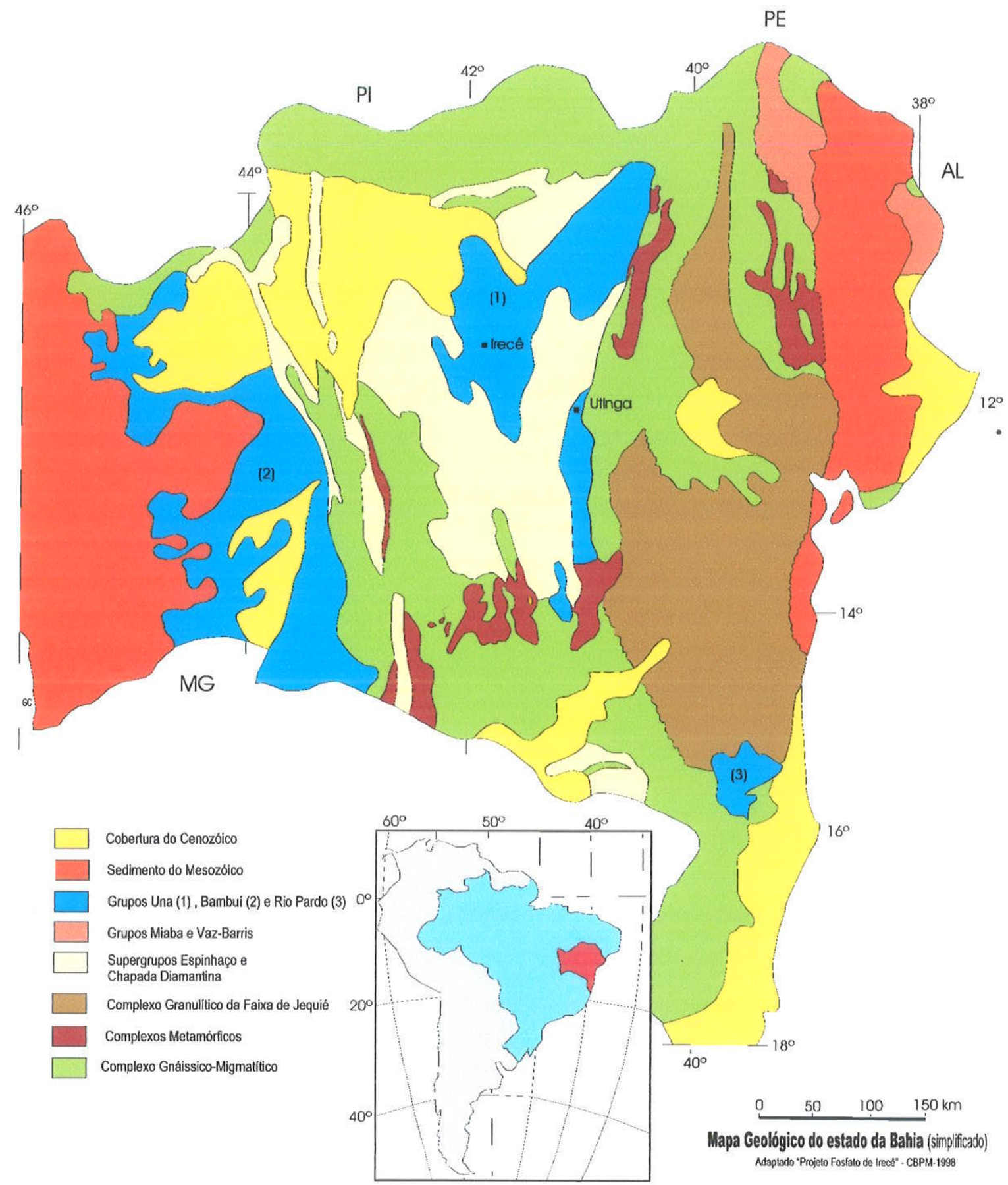

Fonte: CBPM (1998) - Projeto Fosfato de Irecê (adaptado) 
FIGURA 1.2 - GRUPO UNA NO ESTADO DA BAHIA

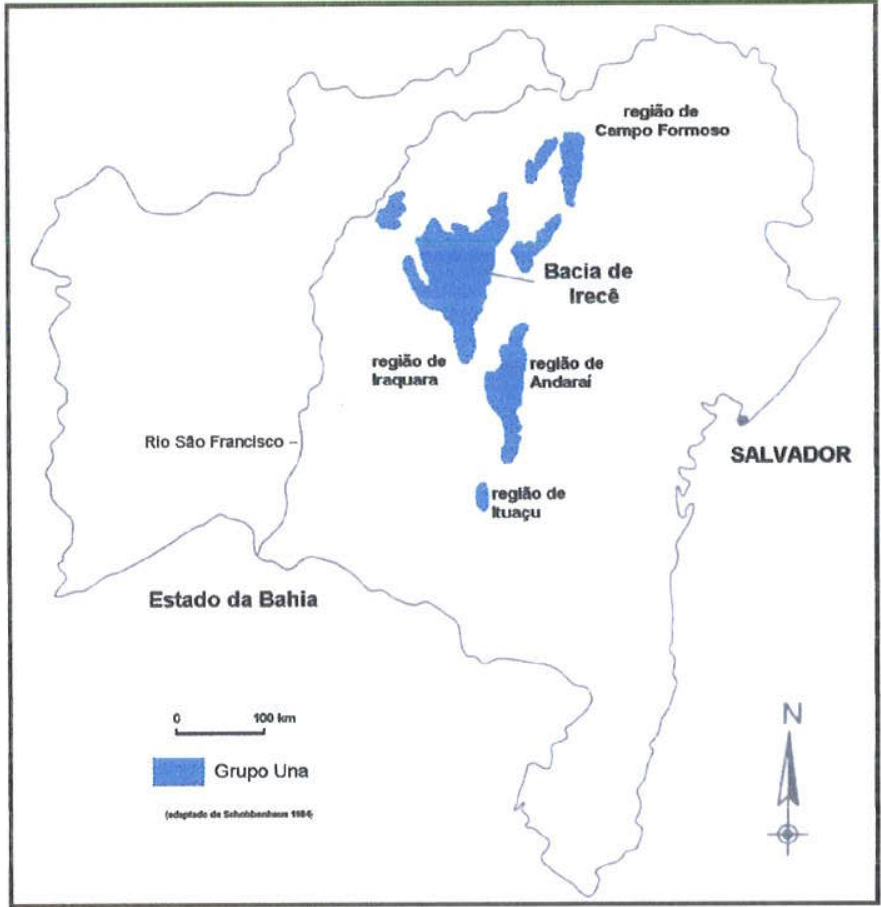

FiguRA 1.3 - MAPA dE LOCALIZAÇÃo dA ÁREA DE ESTUdo

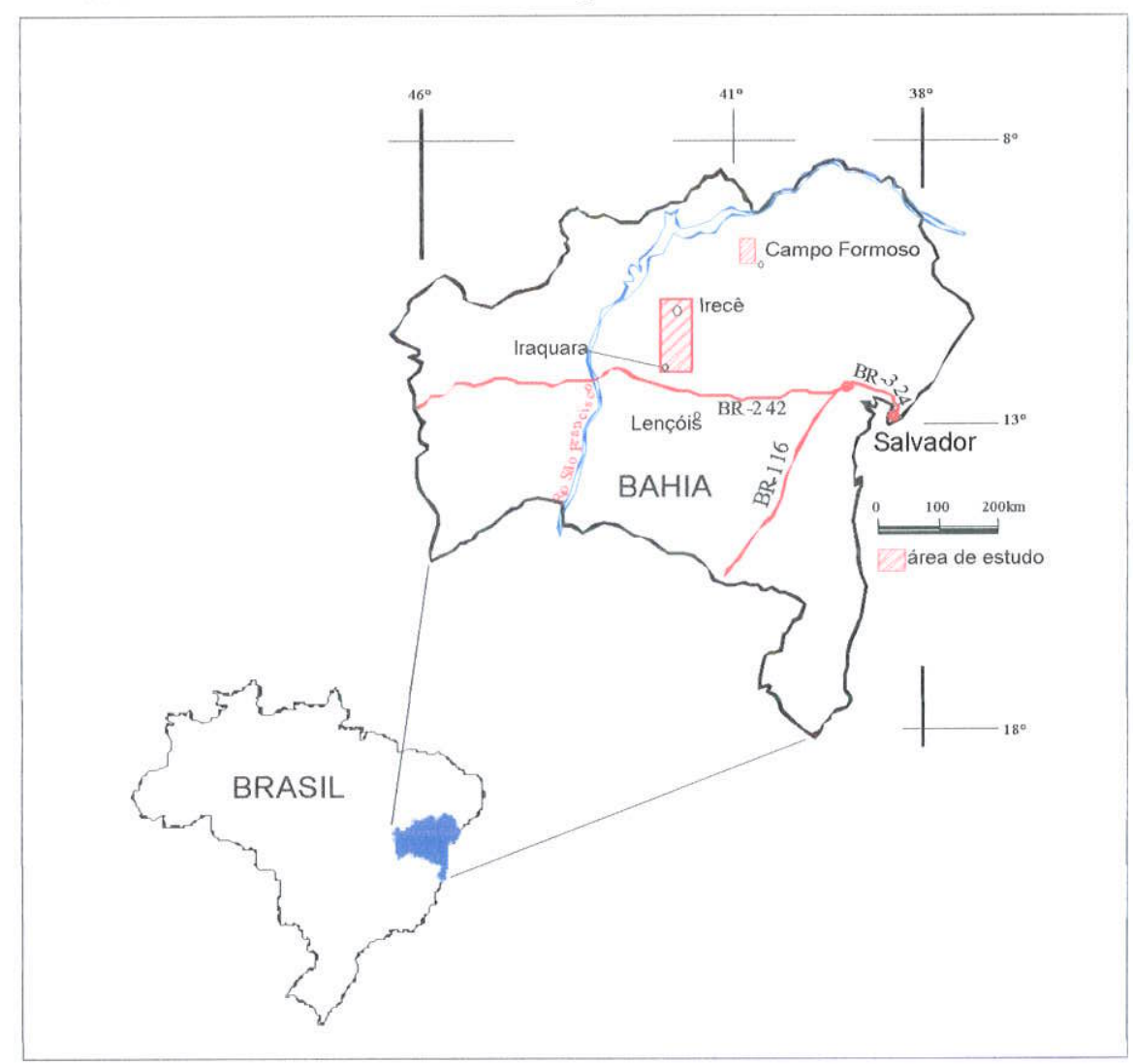




\section{3 - Objetivos da pesquisa}

O objetivo geral desta pesquisa é caracterizar a hidrogeoquímica e geoquímica isotópica do enxofre, associada ao sistema cárstico do Grupo Una, testando a hipótese da participação do ácido sulfúrico na circulação da água subterrânea, visando contribuir para a elaboração de um modelo de evolução de aqüiferos cársticos, do ponto de vista hidroquímico.

Os objetivos especificos são:

- Caracterizar o comportamento hidroquímico e isotópico da água subterrânea através da amostragem em nascentes cársticas e poços tubulares;

- Identificar os agentes corrosivos ativos no sistema cárstico e sua geoquímica;

- Caracterizar a distribuição do enxofre no sistema cárstico, visando identificar as fontes de sulfato para os minerais secundários e nas águas;

- Comparar as características hidroquímicas de águas subterrâneas em sistemas cársticos da região de estudo com exemplos publicados de nascentes que não tenham o componente da influência de ácido sulfúrico;

- Verificar a presença da ação microbiana na produção de $\mathrm{H}_{2} \mathrm{~S}$ e sua participação nos processos de corrosão do carste.

Para atender estes objetivos, as seguintes perguntas deverão ser respondidas:

- Qual(is) o(s) sistema(s) e mecanismo(s) químico(s) que operam (ou operaram) no carste do Grupo Una?

- Existe ação de ácido sulfúrico? Onde age: vadoso, freático, freático profundo?

- Existe participação microbiana nos processos corrosivos do carste? 


\section{CAPÍTULO 2 - CARACTERÍTICAS GEOLÓGICAS E GEOMORFOLÓ. GICAS DA ÁREA DE ESTUDO}

\section{1- Características geológicas}

\subsection{1 - Estratigrafia}

O contexto geológico da área de estudo é do Grupo Una, que, segundo Mascarenhas et al (1984), compreende uma seqüência essencialmente carbonática do Neoproterozóico, assentadas sobre unidades detríticas do Grupo Chapada Diamantina.

O Grupo Una, nas Bacias de Irecê, de Una-Utinga e de Ituaçu, juntamente com o Grupo Bambuí, que ocorre na região oeste do vale do rio Paramirim, na bacia do São Francisco, representam as coberturas sedimentares do cráton do São Francisco pertencentes ao chamado Supergrupo São Francisco (Misi \& Silva, 1996).

Este Supergrupo resulta da sedimentação de uma ampla plataforma carbonática, rasa, que se processou durante o Proterozóico Superior, abrangendo grande parte do território brasileiro.

No que se refere à evolução geológica da Chapada Diamantina Oriental, base para a evolução do contexto do Grupo Una, vale salientar as proposições de Dominguez (1993), que acrescentou novos elementos, do ponto de vista sedimentológico e estratigráfico, para explicar a evolução das bacias sedimentares proterozóicas sobre o cráton do São Francisco. Este autor propõe que durante o Proterozóico Superior, uma extensa invasão marinha nas bordas ocidental e oriental da bacia foi responsável pela sedimentação carbonática do Supergrupo São Francisco. $O$ fim da glaciação, associado a um novo episódio de subsidência, provoca uma subida generalizada do nível do mar, responsável pela sedimentação da plataforma carbonática dos grupos Bambuí e Una. Segundo Misi (1978), existem evidências de que, durante a sedimentação da plataforma carbonática, que se deu em profundidades rasas, ocorreram oscilações do nível do mar, onde pelo menos dois mega-ciclos transgressivos e regressivos estão representados na Bacia de Irecê.

Segundo Costa e Inda (1982) e Dominguez (1993), a Bacia de Irecê preencheu uma depressão limitada por falhas extensionais implantada sobre as rochas do Supergrupo Espinhaço. 
No Estado da Bahia, o Grupo Una, na Bacia de Irecê, é a principal região onde os metassedimentos carbonáticos do Proterozóico Superior foram estudados. Nesta bacia, as seqüências assentam em nítida discordância erosiva sobre os quartzitos do Grupo Chapada Diamantina.

O Grupo Una, na Bacia de Irecê, é dividido em duas formações: a Formação Bebedouro e a Formação Salitre.

A Formação Bebedouro é caracterizada pela presença de metassedimentos síltico-argilosos, aos quais se associam lentes relativamente contínuas de metagrauvacas conglomeráticas, com clastos de tamanhos diversos $e$ formas angulares, o que permite classificar estas rochas como diamictitos de natureza essencialmente glacial (Misi,1979; Misi \& Silva,1996). A espessura da Formação Bebedouro na região centro-norte do estado da Bahia é bastante variável, com valores desde 1 até cerca de 70 metros (figura 2.1).

As unidades basais da Formação Salitre repousam discordantemente sobre as fácies sedimentares da Formação Bebedouro (Misi,1979). Misi (op.cit.) e Misi \& Silva (1996), descrevem a ocorrência de cinco unidades para a Formação Salitre (figura 2.2).

A unidade A1 é formada por calcilutitos pretos e calcários oolíticos e pisolíticos, ricos em matéria orgânica, depositados em ambiente marinho raso e agitado. A unidade A é caracterizada pela predominância de siltitos, argilitos calcíferos e margas de coloração cinza-escura quando não alterados ou cinza-claro quando alterados. A presença de cristais agregados de pirita é comumente observada. Esta unidade representa um aprofundamento da lâmina d'água, podendo caracterizar um ambiente de deposição em mar profundo. A unidade B1 é representada por dolarenitos e dololutitos, com nódulos e lentes individualizadas de sílica. A presença de barita e de pirita, com galena e esfarelita subordinadas podem ser observadas. São freqüentes estruturas sedimentares tipo teepees, que caracterizam a exposição subaérea dos sedimentos em clima árido, além de brechas intraformacionais. Também ocorrem corpos lenticulares de calcários pretos, ricos em matéria orgânica. Ainda segundo Misi \& Silva (op.cit), nesta unidade são marcantes as associações de sulfetos e fosfato. A unidade $\mathbf{B}$ é caracterizada por calcários cinza-claros, finamente laminados e interestratificados com lâminas de argila. Esta unidade representa o resultado de uma sedimentação relativamente profunda. A unidade $\mathbf{C}$ é constituída por dolomitos e 
calcários dolomíticos avermelhados e argilosos, com laminações algais e finíssimas intercalações de frações argilosas.

FIgURA 2.1 - COLUNA LITOESTRATIGRÁFICA DA FORMAÇÃo BEBEDOURO

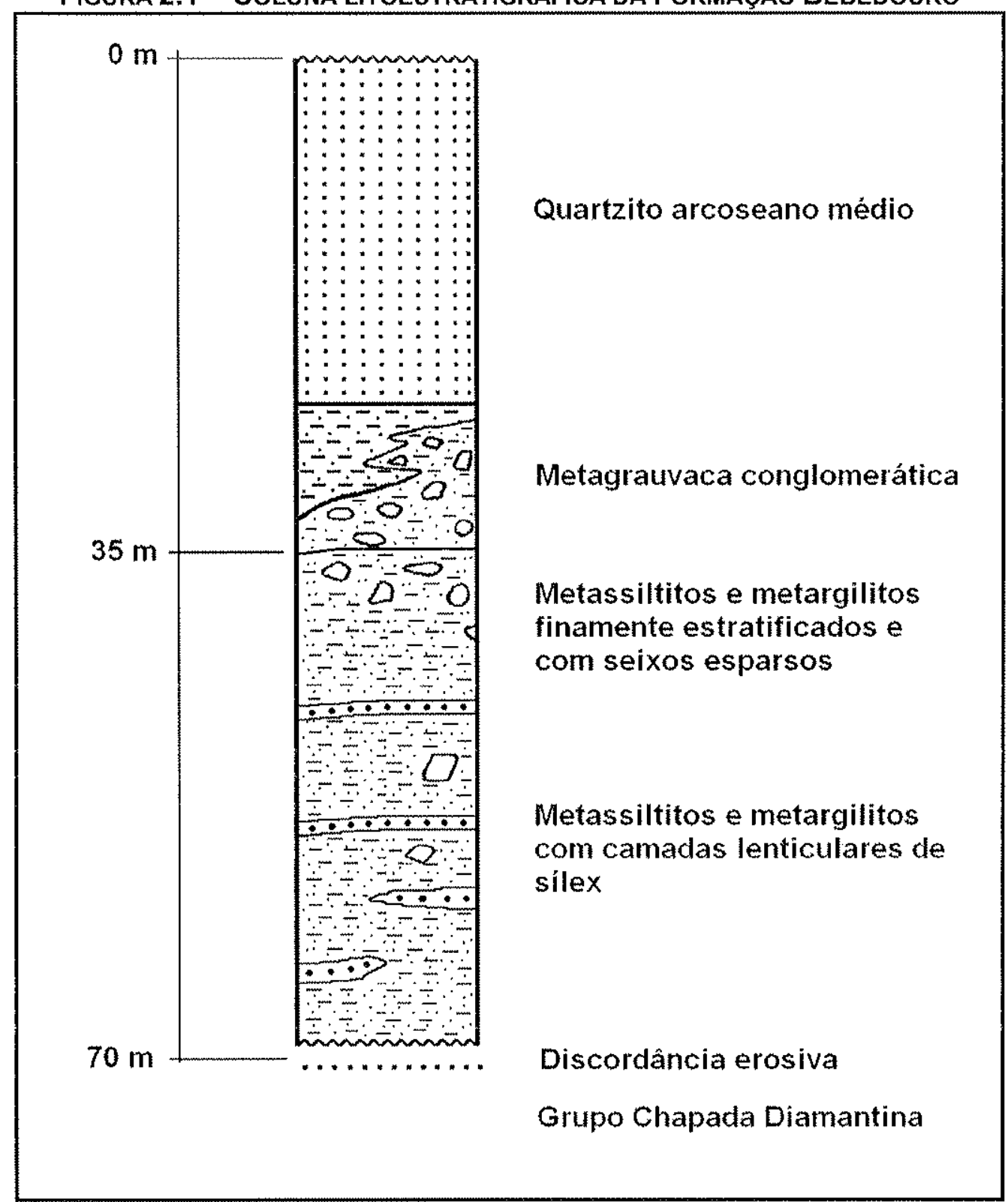

Fonte: Misi\&Silva,1996 (adaptado) 
FIGURA 2.2 - CICLOS DE SEDIMENTAÇÃO - FORMACÃ̃ SALITRE

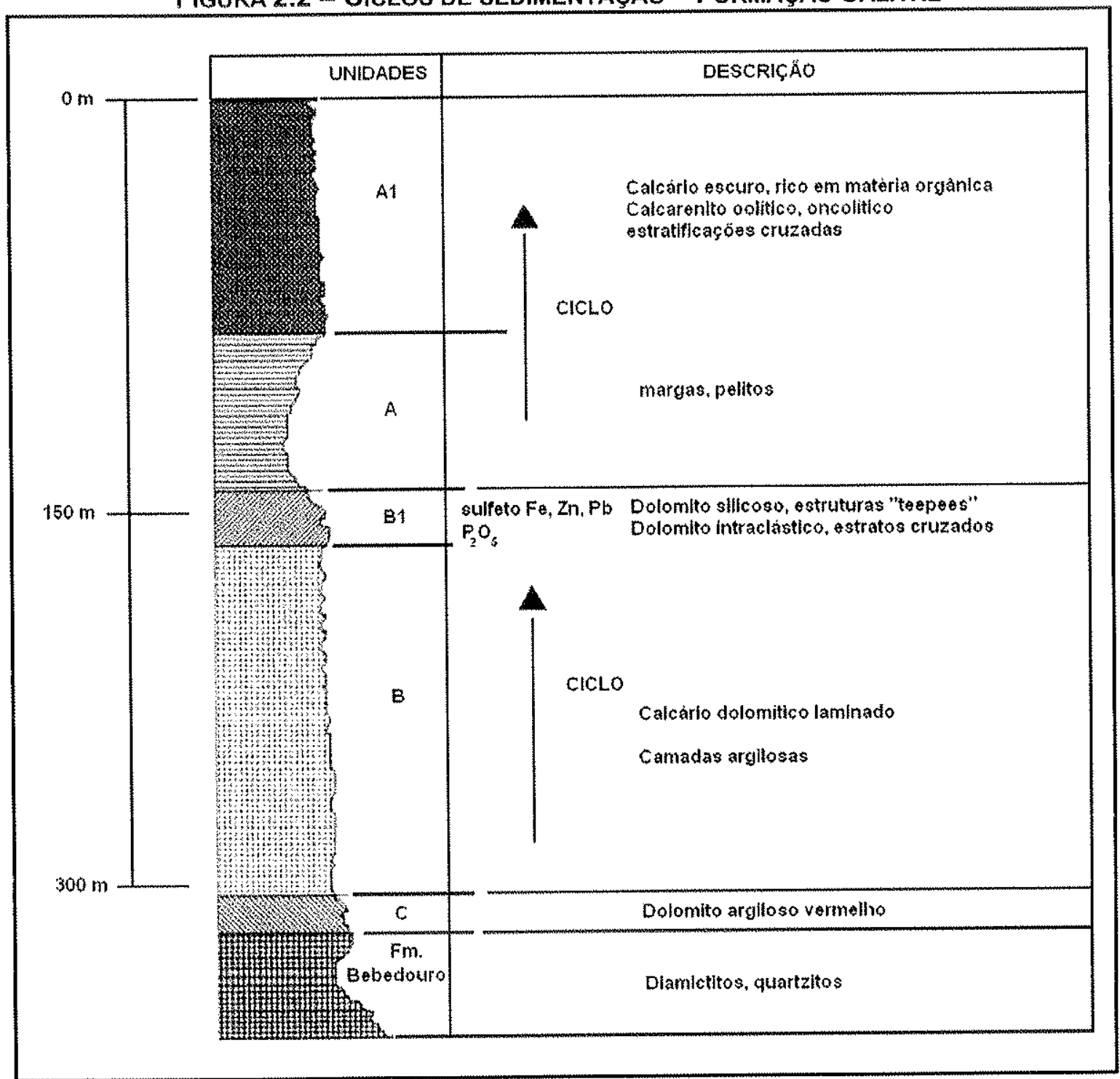

Fonte: Misi \& Kyle, 1994 (adaptado)

As Formações Bebedouro e Salitre (Grupo Una) encontram correlações com unidades do Grupo Bambuí (figura 2.3). Na Bacia de Irecê, as seqüências iniciam-se, da base para o topo, com metassedimentos terrígenos e conglomeráticos (Formação Bebedouro) que correspondem à Formação Macaúbas (Grupo Bambuí). Na região da bacia do Rio São Francisco as seqüências basais do Grupo Bambuí podem estar ausentes, contudo, ocorrências expressivas destas seqüências são observadas próximas a Serra do Espinhaço, prolongando-se no sentido norte em direção à Bahia, onde se pode perceber uma identidade com as unidades líticas descritas na Formação Bebedouro. 
FIGURA 2.3 - CORRELAÇõES LITOESTRATIGRÁFICAS ENTRE OS GRUPOS BAMBUI E UNA

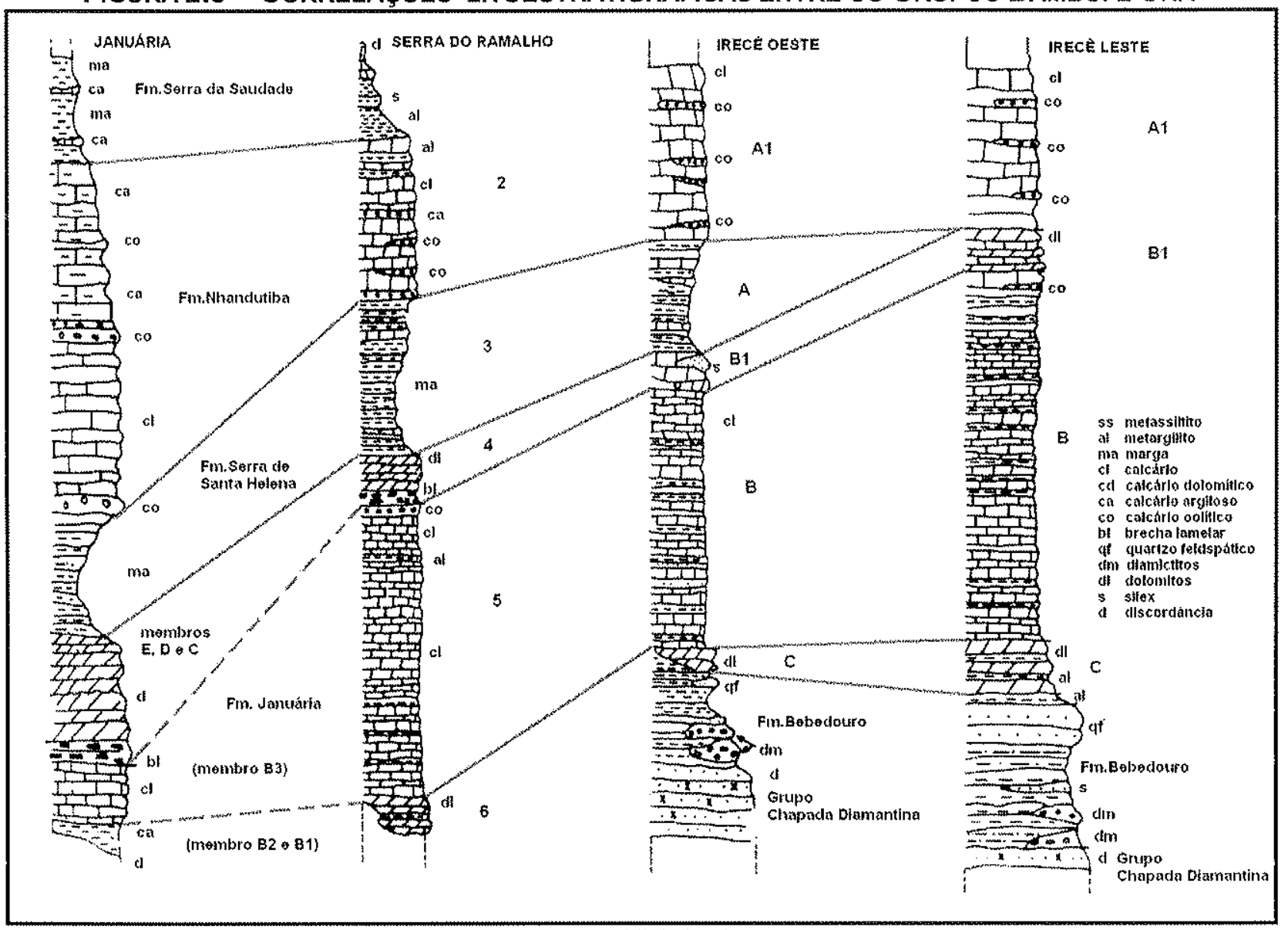

Fonte: Misi, 1979

Os niveis de calcários dolomíticos, dolomitos e argilitos roxos que se sobrepõe à Formação Bebedouro, no Grupo Una (unidade C), encontram seus correspondentes na Serra do Ramalho (BA) e em Januária (MG) (Misi,1979; Mascarenhas et al., 1984). Estas correlações entre as unidades litoestratigráficas do Grupo Una e do Grupo Bambuí da bacia do São Francisco, sugerem um modelo de sedimentação epicontinental para estas seqüências. (Mascarenhas et.al, op.cit. ; Dardenne,1978).

Souza et al. (1993), redefiniram a litoestratigrafia do Grupo Una, na Bacia de Irecê, em unidades informais, associando-as a ciclos de sedimentação marinha regressiva e transgressiva. A repetição das unidades ao longo da coluna estratigráfica significa apenas a recorrência das mesmas condições ambientais ao longo do tempo geológico, onde cada nome designa uma associação específica de litofácies. O quadro 2.1 demonstra as unidades informais descritas por Souza et al. (op.cit.), também representadas em mapa geológico da figura 2.4 . 
FIgURA 2.4 MAPA GEOLÓGICO DO GRUPO UNA BaHIA

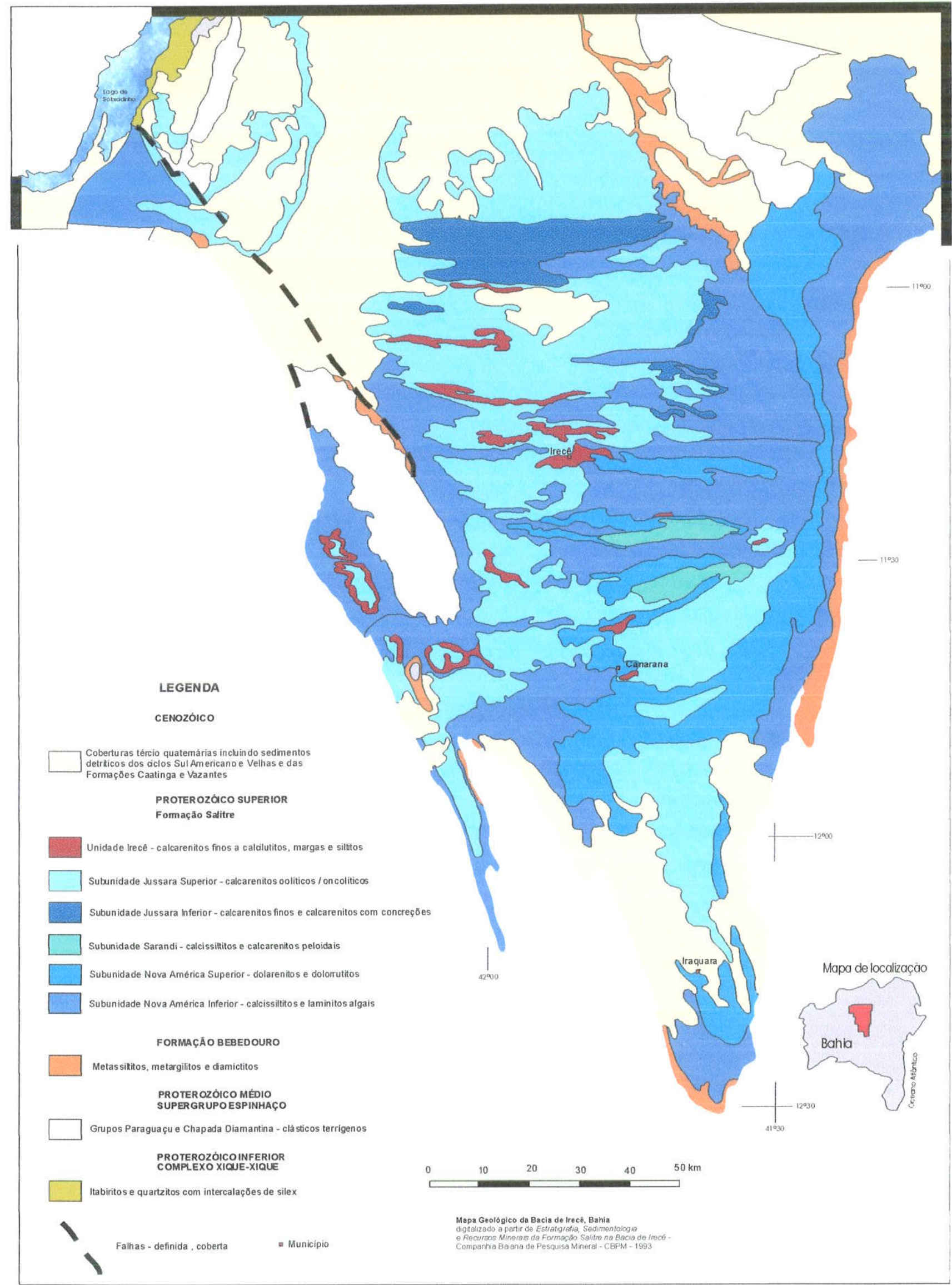


QUADRO 2.1 - UNIDADES INFORMAIS DE FACIES DA FORMAÇÃO SALITRE

\begin{tabular}{|c|c|c|}
\hline ciclo & condição & unidades \\
\hline IV & transgressivo & $\begin{array}{l}\text { Irecê } \\
\text { Jussara Superior } \\
\text { Jussara Inferior }\end{array}$ \\
\hline III & regressivo & $\begin{array}{l}\text { Sarandi } \\
\text { Nova América } \\
\text { Superior } \\
\text { Irecê } \\
\text { Nova América } \\
\text { Inferior }\end{array}$ \\
\hline II & transgressivo & $\begin{array}{l}\text { Jussara Superior } \\
\text { Irecê }\end{array}$ \\
\hline 1 & regressivo & $\begin{array}{l}\text { Irecê } \\
\text { Nova América } \\
\text { Superior } \\
\text { Nova América Inferior }\end{array}$ \\
\hline
\end{tabular}

Os ciclos regressivos I e III compreendem a Unidade Nova América Inferior e Superior. A subunidade Nova América Inferior é constituida por calcissiltito com laminação plano-paralela de coloração cinza-clara, rosada e creme e lamitos algais francamente ondulados de tonalidade negra. Já a subunidade Nova América Superior é caracterizada por uma alternância de bancos carbonáticos distintos entre si, sendo, da base para o topo, constituídos de doloarenitos cinza-claro e doloarenitos oolíticos e oncolíticos de cinza claro a escuro. A subunidade Sarandi está compreendida no ciclo III, e é composta por calcissiltitos e calcarenitos cinzamescuros, com estratificação plano-paralela predominante.

Os ciclos transgressivos II e IV compreendem as unidades Jussara Superior e Jussara Superior e Inferior, respectivamente. A subunidade Jussara Inferior é constituída por calcissiltitos e calcarenitos oolíticos, podendo apresentar também calcarenitos quartzosos e arenitos arcosianos. A subunidade Jussara Superior é representada por calcarenitos finos, médios e grossos, oolíticos e oncolíticos de granulação grossa. A litologia da unidade Jussara é bastante semelhante à subunidade Nova América Superior, distinguindo-se pela ausência de dolomitização e associação 
com estromatólitos colunares. As unidades Jussara Inferior e Superior e Unidade Irecê, estão associadas a fases de transgressão marinha, sendo as duas primeiras caracterizadas por fácies carbonáticas de mar profundo, depositadas em zonas de submaré, enquanto a unidade Irecê, teria se depositado abaixo do nível das ondas. A Unidade Irecê é representada por uma alternância de níveis carbonáticos e terrigenos, sendo os primeiros caracterizados por calcarenitos finos a calcilutitos de cor cinzaescura a negra, e os terrígenos, por siltitos, arenitos imaturos e sílex, com coloração variando entre cinza, creme e rosa. (Souza et al., 1993; Mascarenhas et al.,1984; Misi, 1979).

No que se refere à cobertura das rochas carbonáticas do Grupo Una, observa-se a presença de materiais sedimentares e solos. Segundo Ferrari (1990) a profundidade dos topos rochosos encobertos é muito irregular ao longo da área. Partindo de dados dos perfis litoestratigráficos elaborados por ocasião das construções dos poços da CERB, os solos são definidos como vermelho escuro e vermelho claro, com espessuras variando de 1 a 8 metros. As coberturas sedimentares são constituidas por sedimentos areno-argilosos com a presença indiscriminada de seixos, com espessuras entre 25 e $60 \mathrm{~m}$. Na porção sul, no contato com os metarenitos do Grupo Chapada Diamantina, a cobertura sedimentar e os solos formam camadas muito delgadas com espessuras inferiores a $5 \mathrm{~m}$. Segundo Misi (1979) a espessura da seqüência carbonática do Grupo Una é superior a $400 \mathrm{~m}$.

\subsection{2 - Mineralizações no Grupo Una}

Misi \& Souto (1975), no estudo da Chapada de Irecê, Bahia, revelaram seis mineralizações associadas a Chumbo, Zinco, Flúor e Bário, onde destacam-se as ocorrências de cristais de galena disseminados na calcita, além de pirita, calcopirita, esfalerita e covelita. É comum, nesta zona, o calcário apresentar forte odor de enxofre ao ser quebrado. Posteriormente Misi \& Kyle (1994), estudaram a complexa evolução diagenética dos sedimentos carbonáticos da Formação Salitre, definindo estágios de evolução, que demonstram os processos das mineralizações associados a uma forte participação de sulfetos.

Segundo Misi \& Silva (1996), as coberturas sedimentares do Proterozóico Superior do cráton do São Francisco, apresentam uma gama de depósitos minerais 
economicamente explotáveis, destacando-se: sulfetos de chumbo e zinco, geralmente associados a teores elevados de prata. Neste mesmo estudo, Misi \& Silva (op.cit), descrevem cinco tipos de mineralizações de sulfetos nas seqüências carbonáticas dos Grupos Bambui e Una na Bahia, dos quais quatro estão presentes na Bacia de Irecê, conforme segue: disseminação de galenas em dolomitos silicosos (tipo 1); estratiformes, com galena, esfalerita e pirita, em níveis dolomito-ankeríticos (tipo 3); lenticulares, com quartzo, calcita e galena, preenchendo vazios em calcários laminados (tipo 4); e bolsões e pequenas fraturas nas fácies dolomíticas encaixantes, com calcita, quartzo e galena, às vezes também com pirita e esfalerita (tipo 5). O Grupo Una depositou-se em uma planície de maré, sob condições climáticas áridas, em uma rampa de declividade moderada, o que pode ser interpretado como ambiente de bacia restrita, intermontana, tectonicamente estável, limitada à leste, sul e oeste por elevações do Grupo Chapada Diamantina. As variações do nivel do mar causadas por movimentos epirogenéticos e/ou mudanças climáticas, bem como a geometria do substrato, originaram as variações faciológicas. Os carbonatos representam quatro ciclos de deposição, sendo dois transgressivos (II e IV) e dois regressivos (I e III). É observada na Bacia de Irecê uma relação muito próxima entre a ocorrência de sulfetos, com litologias das subunidades Nova América Inferior e Superior, e com a zona de transição entre elas, o que demonstra que os processos mineralizantes ocorreram nas zonas intermaré e supramaré. Considerando que não houve atividade ígnea na Bacia de Irecê, durante ou após a diagênese dos sedimentos, pode-se inferir que os metais componentes das mineralizações sulfetadas foram lixiviados de rochas continentais e transportados para os locais de deposição (Souza et al,1993).

\section{2 - Situação tectônica e geologia estrutural}

As rochas que compõem as coberturas meso a neoproterozóicas do Cráton do São Francisco, na região da Chapada Diamantina, foram depositadas conforme Dandefer-Filho (1990) e Misi \& Silva (1996), em uma bacia do tipo rift intracontinental ou aulacogênica. Segundo sintese elaborada por Misi \& Silva (op.cit), a história de evolução desta bacia iniciou-se há 1,7Ga, com a ruptura de parte do embasamento por falhamentos extensionais de direção NNW-SSE, concomitantemente com a deposição das rochas da Formação Paraguaçu e Vila dos Remédios. Posteriormente ocorreram 
os eventos de alargamento e subsidência da bacia e sedimentação das rochas pertencentes ao Grupo Chapada Diamantina e Grupo Una. O estágio final de evolução, ocorrido no final do Proterozóico Superior, é caracterizado pela inversão do sulco da bacia e elevação das coberturas.

Segundo Dandefer-Filho (1990) a Bacia de Irecê é caracterizada pela ocorrência de um conjunto de megadobras, representadas pela sucessão de suaves anticlinais e sinclinais, de dimensões variáveis entre quilômetros e dezenas de quilômetros, com orientação dos eixos segundo a direção NNW-SSE.

Misi (1979) descreve que a faixa carbonática do Grupo Una consiste em um grande sinclinal, margeado por dois anticlinais, a oeste e a leste na direção de maior prolongamento da faixa. Os mergulhos das camadas do platô carbonático são suaves, variando entre 10 a $15^{\circ}$ (figura 2.5).

Segundo Dandefer-Filho (1990), as falhas de empurrão de alto ângulo, com direção NNW-SSE são significativas. Os principais conjuntos de fraturas medidas principalmente em rochas do Grupo Chapada Diamantina, correspondem a juntas longitudinais com espaçamento métrico e direção perpendicular ao eixo das dobras regionais; fraturas diagonais ao eixo das dobras, com direções NE-SW e E-W e também as fraturas preenchidas, com direção WSW-ENE (Cruz Junior, 1998).

\section{3 - Elementos Geomorfológicos}

O relevo da Chapada Diamantina é caracterizado pela presença de planaltos e serras, situados em altitudes que variam entre $300 \mathrm{~m}$ a $1700 \mathrm{~m}$, sendo que as diferenças altimétricas e morfológicas acompanham geralmente a disposição dos litotipos (Cruz Jr, 1998). Segundo Pedreira-da-Silva (1994), os domínios geomorfológicos da região são divididos em dois, sendo um, representado pelos planaltos e serras em rochas predominantemente siliciclásticas, ocorrendo nos intervalos de $800 \mathrm{~m}$ a $1100 \mathrm{~m}$ e o outro representado pelos planaltos cársticos, ocorrendo nos intervalos de $600 \mathrm{~m}$ a $800 \mathrm{~m}$, com litologia associada aos carbonatos do Grupo Una. O planalto cárstico é caracterizado por relevos suaves, com ocorrência de amplas bacias poligonais de drenagem centrípeta, sendo recoberto em expressiva parcela, por solos carbonáticos e depósitos aluvionares e coluvionares. 
Segundo Cruz Jr (1998), o planalto cárstico é caracterizado por relevos suavemente ondulados situados no sopé das maiores elevações, o qual possui cotas máximas entre 750 a 800 m junto ao contato geológico com as rochas não carbonáticas e também na porção norte da área. Feições importantes desse planalto correspondem a vales bem encaixados com vertentes escarpadas, ultrapassando em alguns casos $40 \mathrm{~m}$ de profundidade e a ocorrência de uma grande quantidade de depressões cársticas. Os pontos mais baixos do relevo são encontrados ao longo do vale do Rio Santo Antônio, com piso situado a aproximadamente $600 \mathrm{~m}$ de altitude. Este vale compreende o nível de base do aqüifero na área. A maior parte do planalto cárstico na área de estudo encontra-se coberto por solos carbonáticos e também por depósitos coluvionares e aluvionares. No restante do planalto de Irecê, os trechos com rochas aflorantes são mais comuns.

Guerra (1986) descreve que a distribuição de dolinas na Bacia de Irecê ocorre de forma não uniforme, destacando maior concentração na porção sul. Segundo Cruz Jr (1998), na porção norte as dolinas são em menor quantidade e, predominantemente, rasas, esparsas e de pequeno porte; na porção sul são mais freqüentes, com dimensões maiores e morfologia de abatimento onde a ocorrência de grutas é significativa, apresentando sistemas de cavernas com projeções horizontais superiores a $5 \mathrm{~km}$. As dolinas do setor sul da bacia, de um modo geral, são ocasionadas por colapso, cujas feições são atribuídas à presença de grandes salões de abatimento que interceptaram a superfície.

Figura 2.5- SEçÃo geológica (SW-NE) do GRupo UNA NA BACIA DE IRECÊ

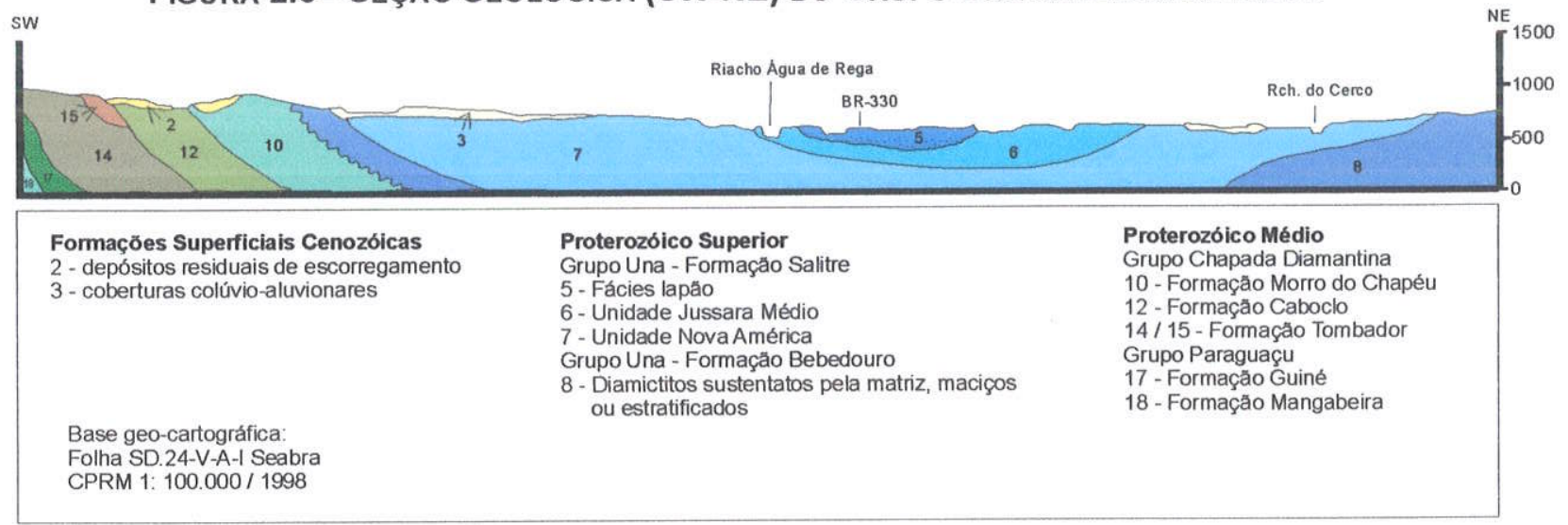




\section{CAPÍTULO 3 - MÉTODOS E TÉCNICAS}

A pesquisa realizada relacionou parâmetros químicos das águas, rochas e minerais, com vistas ao entendimento da dinâmica erosiva do aqüífero cárstico no contexto do Grupo Una através de estudos geoquímicos, hidrológicos, mineralógicos, petrológicos e microbiológicos.

Inicialmente dividiu-se a área de estudo em dois setores: norte, caracterizado pela bacia do rio Salitre e sul pela bacia de Irecê. (figura 1.3)

As amostragens de águas para análises químicas, físico-químicas e as medidas hidrológicas foram realizadas entre julho de 2002 e setembro de 2003, com intervalos de cerca de 3 meses que tiveram como objetivo a cobertura das variações sazonais. Foram selecionados 14 pontos de amostragem (figuras 3.1 e 3.2 ), cobrindo os diferentes ambientes de fluxo do carste e sua recarga.

As atividades analíticas descritas a seguir foram subdivididos em função dos objetivos (quadro 3.1) e em função da sistemática adotada.

QUADRO 3.1 - QUADRO SÍNTESE DAS ATIVIDADES ANALITICAS

\begin{tabular}{|c|l|}
\hline \multicolumn{1}{|c|}{ objetivo } & \multicolumn{1}{|c|}{ Atividades analíticas } \\
\hline Geoquímica & $\begin{array}{l}\text { Hidroquímica das águas naturais } \\
\text { Isótopos estáveis de } \mathrm{S} \text { em rochas e minerais } \\
\text { Isótopos estáveis de } \delta^{18} \mathrm{O} \text { e } \delta \mathrm{D} \text { em água } \\
\text { Análises de rochas }\end{array}$ \\
\hline $\begin{array}{c}\text { Monitoramento } \\
\text { hidrológico }\end{array}$ & $\begin{array}{l}\text { Medição de vazão } \\
\text { Medição da variação de nivel de nascentes e reservatórios } \\
\text { Medições pluviométricas }\end{array}$ \\
\hline Mineralogia & identificação mineral (difratometria de Raio $\mathrm{X}$ ) \\
\hline Microbiologia & $\begin{array}{l}\text { Identificação de espécies através de cultura bacteriológica em } \\
\text { água e rocha }\end{array}$ \\
\hline
\end{tabular}


FIGURA 3.1 - LOCALIZAÇÃO DOS PONTOS DE COLETA (BACIA DE IRECÊ)
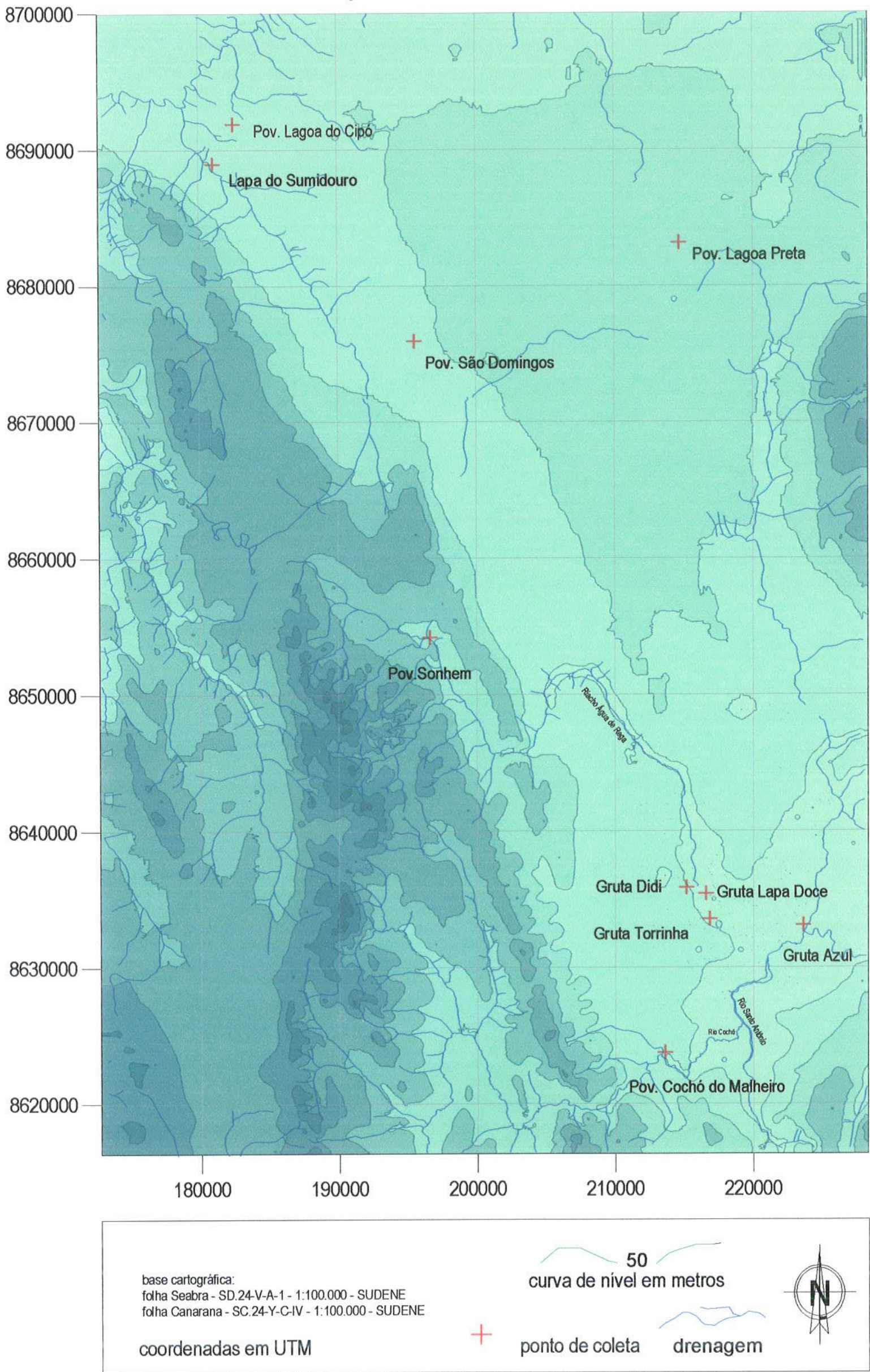
Figura 3.2 - LocAlizAçÃo doS PONTOS DE COLETA (BACIA DO RIO SALITRE)

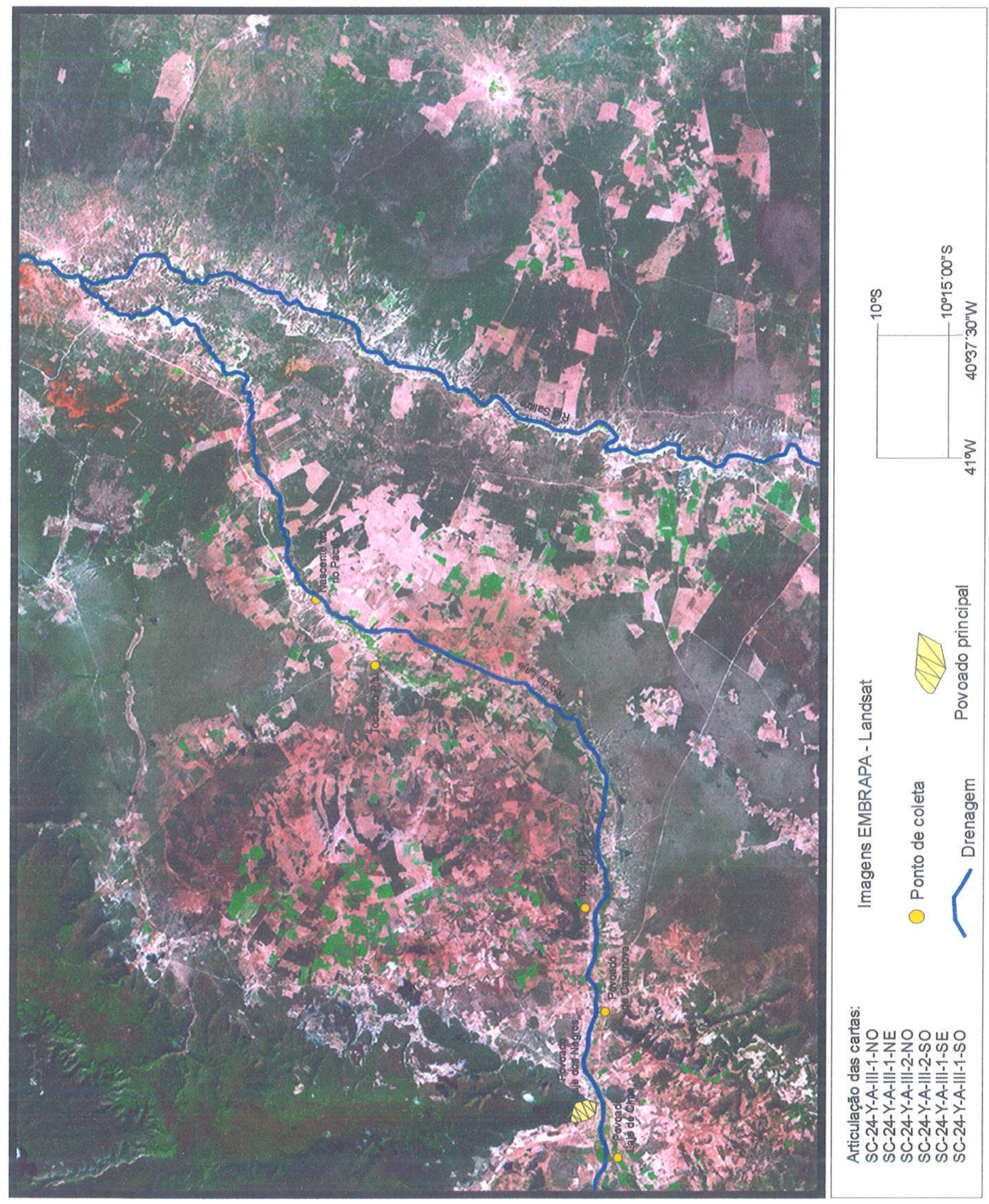




\section{1 - Geoquímica}

\subsection{1 - Hidroquímica das águas naturais}

O estudo da dinâmica atual foi fundamentado em coletas e análises periódicas das águas de percolação do maciço carbonático (gotejamentos rápidos e lentos em cavernas), de poços tubulares, de nascentes cársticas, de escoamento alogênico e de chuva, onde foram determinadas as concentrações dos principais cátions e ânions $\left(\mathrm{Ca}^{2+}, \mathrm{Mg}^{2+}, \mathrm{K}^{+}, \mathrm{Na}^{+}, \mathrm{Fe}^{2+}, \mathrm{Mn}^{2+}, \mathrm{Ba}^{2+}, \mathrm{Sr}^{2+}, \mathrm{Cl}^{-}, \mathrm{HCO}_{3}{ }^{-}, \mathrm{SO}_{4}{ }^{2-}\right.$, e os parâmetros físicoquímicos ( $\mathrm{pH}, \mathrm{Eh}$, condutividade elétrica).

Considerando a sensibilidade à alteração do sistema $\mathrm{H}_{2} \mathrm{O}-\mathrm{CO}_{2}-\mathrm{H}_{2} \mathrm{CO}_{3}$ (Domenico \& Schwartz, 1990; Stumm \& Morgan, 1995), foi montado um laboratório de campo para realização de análises químicas para a determinação de carbonatos, bicarbonatos e dureza total, poucas horas após a coleta das amostras. As amostras foram transportadas sob refrigeração até a base dos trabalhos de campo, onde se realizaram as análises.

\subsubsection{1 - Sistemática de coleta}

Foram utilizados frascos de polietileno branco-translúcido de $60 \mathrm{~mL}$ (Nalgene( $($ )). Os frascos foram lavados com detergente neutro, enxaguados por 3 vezes com água destilada, em seguida com $\mathrm{HCl} 0,5 \mathrm{~mol} / \mathrm{L}$ e finalmente enxaguados por duas vezes com água deionizada. Os frascos foram separados em conjuntos recebendo individualmente numeração seqüencial, com o prefixo BA, e identificação do destino analítico. Cada conjunto recebeu dois frascos de vidro âmbar $(10 \mathrm{~mL})$, para análises isotópicas e 3 frascos de polietileno $(60 \mathrm{~mL})$, para análise de cátions, ânions e titulação.

As amostras de água, antes de serem envasadas, foram filtradas a vácuo, utilizando filtro de campo com membrana de nitrocelulose de 0,45 $\mu \mathrm{m}$. Amostras para análise de ânions, foram adicionadas 3 gotas de ácido nítrico concentrado $\left(\mathrm{HNO}_{3}\right)$ no frasco. Os frascos foram transportados sob refrigeração. As águas de nascentes cársticas, escoamento alogênico e de reservatórios subterrâneos foram coletadas com auxílio de um béquer, imergido diretamente no local. As águas de poços foram coletadas após abertura do poço e escoamento da água por 5 minutos. Para coleta de águas de percolação vadosa, gotejamento de estalactites, foram adotadas duas técnicas. A primeira consistiu na conexão de uma mangueira de silicone diretamente na ponta do espeleotema que está gotejando, levando o líquido diretamente para o frasco 
(figura 3.3), e a outra, quando não foi possível a adoção do sistema anterior, consiste no ajuste do frasco de coleta o mais próximo do ponto de gotejamento.

Figura 3.3 - ColetA dE ÁguA EM GOTEJAMENTO DE ESTALACTITES

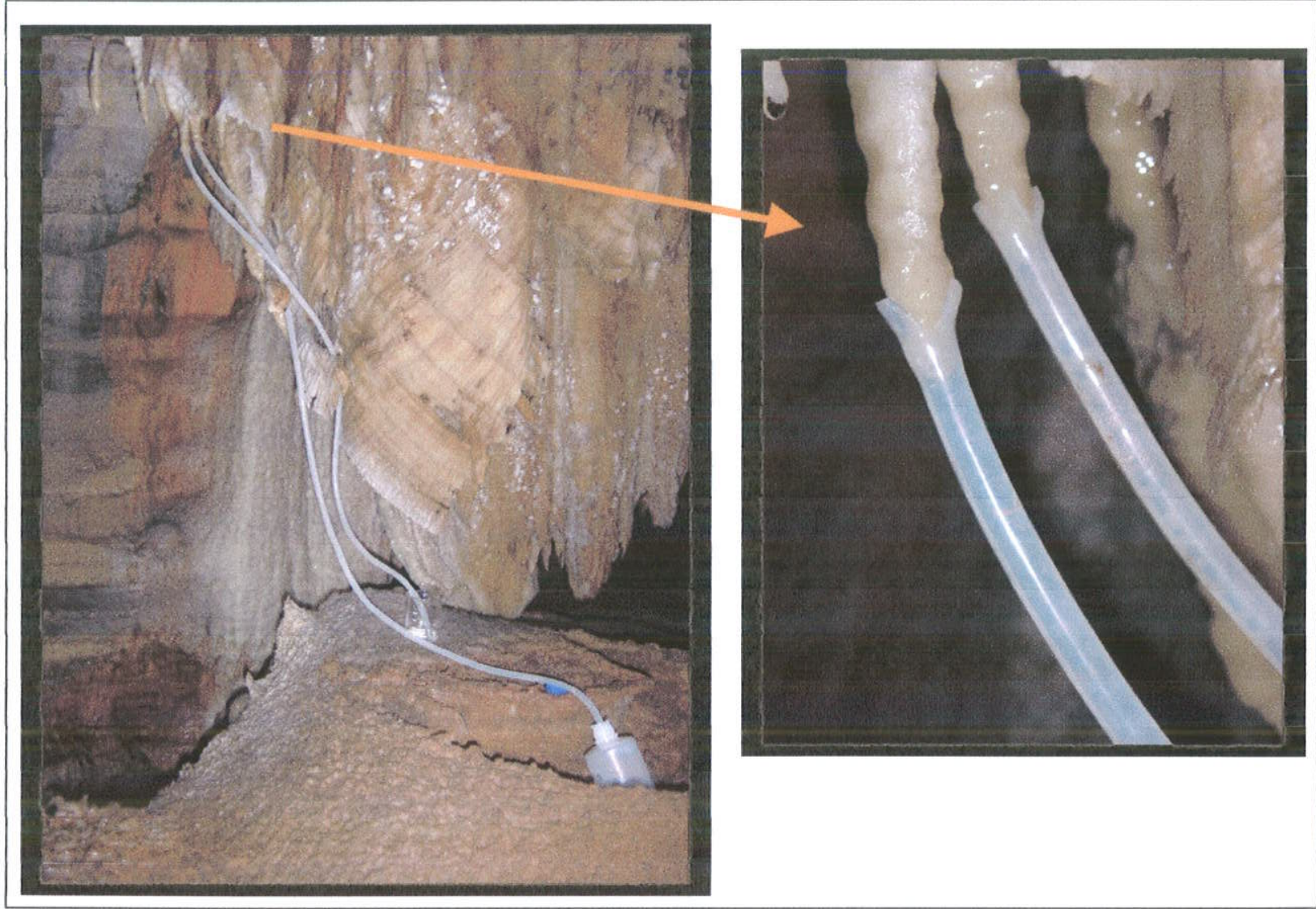

As amostragens de águas de chuva foram efetuadas apenas com chuva intensa. Uma lona plástica, branca-translúcida, de dimensões $4 \mathrm{~m} \times 2 \mathrm{~m}$, foi armada em um terreno particular, de forma a ficar esticado, no alto, com vinco e uma leve queda para uma das extremidades. As amostras foram coletadas após, no mínimo 30 minutos de chuva intensa.

Para a medição de $\mathrm{pH}$, Eh, temperatura e condutividade elétrica, utilizou-se um aparelho multiparâmetro, marca Orion, modelo 2230, equipamento este que possui eletrodos específicos para cada parâmetro. Em todas etapas de campo o equipamento foi aferido com os padrões 7,00 e 10,00 para pH e 14,16 $\mu \mathrm{S} / \mathrm{cm}$ para condutividade elétrica. Este equipamento permite precisão de 0,01 na determinação do $\mathrm{pH}$, e as medidas são automaticamente compensadas para a temperatura padrão de $25^{\circ} \mathrm{C}$. 


\subsubsection{2 - Análises químicas}

No laboratório de campo determinaram-se bicarbonatos e carbonatos por titulação acidimétrica com HCl (Vogel, 1992; Eaton et al, 1995) e dureza total por titulação com EDTA (Vogel, op.cit; Eaton et al, op.cit).

Os demais parâmetros químicos foram analisados em laboratórios específicos.

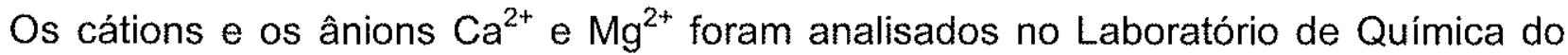
IGc/USP, em espectrômetro de emissão óptica com plasma induzido acoplado (ICP. OES) modelo ARL-3410 da Applied Research Laboratories. A margem de erro dos resultados é inferior a 1\%. Os ânions foram analisados no Laboratório de Hidroquímica do Centro de Pesquisas de Águas Subterrâneas (CEPAS) do IGc/USP, sendo $\mathrm{Na}^{+}$e $^{+}$ em fotômetro de chama Micronal e demais em cromatógrafo de íons marca Dionex, modelo $2010 i$, ambos com margem de erro máxima de $1 \%$.

\subsection{2 - Análise de isótopos estáveis}

\section{Enxofre $-\delta^{34} \mathrm{~S}$}

As amostras de gipsita (espeleotema) foram pulverizadas e submetidas a análise. $\mathrm{Na}$ água, o enxofre presente sob a forma de sulfato, foi separado por precipitação com $\mathrm{BaCl}_{2}$ (Vogel, op.cit; Eaton et al, op.cit). As análise de isótopos estáveis $-\delta^{34} S$, dos sulfetos e sulfatos foram executadas por Espectrometria de massa no Isotope Science Laboratory da Universidade de Calgary - Canadá, em equipamento Carlo Erba modelo NA1550 (IRMS) com padrão V-CDT (Canyon Diablo Troilite Vienna). A margem de erro dos resultados analíticos é de $1 \%$.

\section{Carbono $-\delta 13 \mathrm{C}$}

Os isótopos estáveis de carbono em rocha foram analisados a partir de moagem da rocha. $\mathrm{Na}$ água, o carbono presente sob a forma de hidrogenocarbonato, foi precipitado com $\mathrm{CaCl}_{2}$ (Vogel, op.cit; Eaton et al, op.cit). As análises foram efetuadas no Laboratório de Isótopos Estáveis do Centro de Estudos e Pesquisas Geocronológicas do Instituto de Geociências da USP, em equipamento marca Europa modelo Geo20-20, com padrão de referência PDB-V (Pee Dee Belemnite - Vienna) 


\section{2 - Monitoramento hidrológico}

\subsection{1 - Medição de vazão}

A vazão foi medida pelo método velocidade-área, com a utilização de molinete fluviométrico marca General Oceanics, modelo 2030, equipado com hélice propulsora (rotor) para fluxos de baixa e alta turbulência, trena de pvc com incremento de $0,5 \mathrm{~cm}$ e régua de alumínio graduada e com incremento de $5 \mathrm{~cm}$. As medições da velocidade de fluxo da água foram efetuadas ao longo da seção transversal do rio em pontos eqüidistantes em $0,5 \mathrm{~m}$, sendo que para cada ponto, em função da profundidade, foram realizadas medidas verticais eqüidistantes em $30 \mathrm{~cm}$. Cada setor onde o molinete é posicionado representa uma área, que é multiplicada pelo valor obtido de velocidade, para obter um valor de vazão para aquele setor. A soma das vazões de todos os setores resulta na vazão total.

\subsection{2 - Variação do nível da água nas nascentes cársticas}

$\mathrm{Na}$ nascente da Pratinha, o monitoramento compreendeu a instalação de medidor de nível digital marca Global Water, modelo WL14, equipado com registrador automático (data logger) e software de controle monitorado com auxílio de microcomputador portátil. Como referência para o registro da variação de altura da lâmina d'água, instalou-se junto ao equipamento uma régua vertical graduada. $\mathrm{Na}$ nascente do Pacuí, tendo em vista as características se segurança do local, não foi possivel instalar um medidor de nivel. Instalou-se uma régua, com incremento de $5 \mathrm{~cm}$, e um morador das proximidades mensalmente efetuou leituras, anotando em caderneta especifica.

\subsection{3 - Medição pluviométrica}

A pluviometria foi realizada utilizando-se pluviômetros da marca Davis, equipados com armazenador de dados marca Hobo, modelo Hobo event. Este equipamento possui uma estrutura plástica, com boca de $25 \mathrm{~cm}$ de diâmetro. Internamente é composto por um sistema de copos-pêndulo, cujo software armazena a quantidade de vezes que este conjunto oscila. De posse do volume de cada copo, 
multiplica-se pela quantidade de eventos para determinar o volume de chuva. Para transformar em milímetros, multiplica-se o número de eventos por 0,2.

\section{3 - Identificação mineral}

Os minerais foram identificados por difratometria de raio $X$ no Laboratório de Raio $X$ do IGc/USP. As amostras de minerais foram pulverizadas manualmente em gral de ágata, sendo dispostas em dispositivos específicos do aparelho. $O$ equipamento utilizado foi um difratômetro de Raios-X, marca Siemens, D5000. Os difratogramas foram gerados a partir do software Diffact plus e interpretados com o apoio do técnico responsável do laboratório, sr. Flávio Machado.

\section{4 - Microbiologia}

Três amostragens, efetuadas em Julho e Outubro de 2002 e Setembro de 2003, foram realizadas nos mesmos pontos de coleta selecionados para as análises hidroquímicas e mineralógicas com o objetivo no isolamento de bactérias oxidantes (Thiobacillus) e redutoras de enxofre.

Amostras de água para a análise microbiológica, foram coletadas de acordo com - "Guia de orientação e preservação de amostras de água" (CETESB, 1988) em frascos de polipropileno estéreis e transportadas sob refrigeração. O processamento ocorreu em periodo inferior a 24 horas à amostragem. Fragmentos de rochas de interesse também foram coletadas e acondicionadas em sacos estéreis.

\subsection{1 - Pesquisa de Thiobacillus thioparus}

Na primeira série de coletas fez-se uma avaliação microbiológica preliminar com realização de ensaio em campo para diferentes espécies de bactérias do gênero Thiobacillus. Foram pesquisadas as espécies $T$. thioparus, $A$. thiooxidans, $A$. ferrooxidans e T. denitrificans empregando-se a Técnica de Tubos Múltiplos (TM) (Shirakawa, 1994 e Cetesb 1991) e Técnica de Membrana Filtrante (MF) (Eaton et al, 1995), com filtração de volumes diferentes das amostras através de membranas de acetato de celulose estéreis (poros de $0.45 \mu \mathrm{m}$ e $47 \mathrm{~mm}$ de diâmetro - Millipore), com inoculação em meio Postgate seletivo para as diferentes espécies citadas (quadro 3.2). Após a avaliação inicial, sendo a espécie $T$. thioparus a única com resultados positivos 
para as amostras de água analisadas, somente esta espécie foi pesquisada empregando-se a Técnica de Tubos Múltiplos em meio Postgate segundo Shirakawa, (1994) e Cetesb (1991).

QUADRO 3.2 - MEIOS DE CULTURA UTILIZADOS PARA DETERMINAÇAO DE ESPÉCIES DE THIOBACILLUS

\begin{tabular}{|l|c|c|c|}
\hline \multicolumn{1}{|c|}{ Meio de cultura } & $\begin{array}{l}\text { Espécies de } \\
\text { Thiobacillus }\end{array}$ & Reação & Indicação de crescimento \\
\hline $\begin{array}{l}\text { Postgate modificado com vermelho de } \\
\text { fenol }\end{array}$ & T.thioparus & $\mathrm{S}_{2} \mathrm{O}_{3}{ }^{2}-\mathrm{H}_{2} \mathrm{SO}_{4}$ & $\begin{array}{l}\text { Viragem do indicador vermelho para } \\
\text { amarelo }\end{array}$ \\
\hline $\begin{array}{l}\text { Postgate modificado com verde de } \\
\text { bromocresol }\end{array}$ & A.Thiooxidans & $\mathrm{S}_{2} \mathrm{O}_{3}{ }^{2}-\mathrm{H}_{2} \mathrm{SO}_{4}$ & Oxidação de Fe2+ verde para laranja \\
\hline Meio 9K com FeSO4 & A.ferrooxidans & $\mathrm{Fe}^{2+}-\mathrm{Fe}^{3+}$ & $\begin{array}{l}\text { Viragem do indicador verde para } \\
\text { amarelo }\end{array}$ \\
\hline $\begin{array}{l}\text { Postgate modificado com } \mathrm{KNO3} \mathrm{e} \\
\text { NaHCO3- }\end{array}$ & T.denitrificans & $\mathrm{S}_{2} \mathrm{O}_{3}{ }^{2}-\mathrm{H}_{2} \mathrm{SO}_{4}$ & $\begin{array}{l}\text { Viragem do indicador vermelho para } \\
\text { amarelo }\end{array}$ \\
\hline
\end{tabular}

Nesta técnica diluições decimais da amostra nos volumes de $10^{\circ}$ até $10^{-2}$ foram inoculados em meio Postgate (Postgate, 1979) e incubados até 21 dias, $20^{\circ} \mathrm{C}$. A leitura positiva foi determinada pela viragem do $\mathrm{pH}$ do meio de cultura de vermelho $(\mathrm{pH} 7,4)$ para amarelo (abaixo de 6.5).

A pesquisa de Thiobacillus em amostras de rochas e/ou sedimentos foi realizada através do inoculo de $10 \mathrm{~g}$ da amostra em $50 \mathrm{~mL}$ do meio Postgate modificado para $T$. thioparus, contido em frascos erlenmeyers. A cultura foi mantida em shaker a $20^{\circ} \mathrm{C}$ por dez dias e mais dois repiques sucessivos foram realizados sob as mesmas condições para a confirmação do enriquecimento.

Amostras de sedimentos e piritas presentes em rochas coletadas foram processados e $10 \mathrm{~g}$ dos mesmos colocados em erlenmeyers contendo $50 \mathrm{~mL}$ do meio de cultura T\&K (Tuovinen \& Kelly, 1973). As culturas foram mantidas em shaker a $20^{\circ} \mathrm{C}$ por dez dias e mais dois repiques sucessivos foram realizados sob as mesmas condições para a confirmação do enriquecimento. Controles positivos e negativos dos meios foram realizados em paralelo.

\subsection{2 - Pesquisa de Bactérias Redutoras do Sulfato (BRS)}

A pesquisa de BRS foi realizada através das metodologias da Técnica Tubos Múltiplos, segundo Sakamoto (1996). A leitura dos frascos de NMP (número mais provável) foi realizada através da observação de turbidez e presença de $\mathrm{H}_{2} \mathrm{~S}$. Para isso, dispensou-se aliquotas dos frascos turvos em papel filtro embebido em uma 
solução de acetato de chumbo. A reação escura com o sulfeto, se presente no meio, indicava crescimentos das BRS. A confirmação da presença das redutoras de sulfato realizadas através da técnica de FISH (Hibridação "in situ" com sondas fluorescentes segundo Gomes et al. (2003)).

Para as hibridações, alíquotas de 1 a $2 \mu \mathrm{L}$ das amostras foram fixadas em tampão de fixação e guardadas em freezer $\left(-20^{\circ} \mathrm{C}\right)$ até o momento da hibridização. A hibridização das amostras foram realizadas com a sonda SRBDb, utilizada em conjunto com a sonda SRB385 para detectar bactérias redutoras de sulfato.

Todas as lâminas preparadas tiveram, além das amostras, um controle positivo e um negativo. As linhagens utilizadas como controles foram a Escherichia coli (controle positivo para a sonda EUB338 e negativo para as demais), a Desulfovibrio vulgaris (controle positivo para as sondas SRBDb/SRB385 e negativo para ARCH915) e a Methanobacterium formicicum (controle positivo para ARCH915 e negativo para as demais). Além disso, para verificar a ocorrência de autofluorescência, foram preparadas lâminas com as amostras sem adição de sonda e sem coloração com DAPI, utilizando como controle uma cultura de Escherichia coli.

As lâminas com as amostras hibridadas foram observadas em microscópio Zeiss modelo Axiovert S100, com câmera CCD Hamamatsu. O processamento das imagens feito através do software KS400 Imaging System 3.0.

As análises microbiológicas de água foram realizadas pelo Laboratório de Microbiologia do Instituto de Ciências Biomédicas da USP (ICB/USP), sob a coordenação da prof ${ }^{a}$ Dra Vivian Helena Pellizari.. 


\section{CAPÍTULO 4 - HIDROQUÍMICA DAS ÁGUAS NATURAIS - DINÂMICA ATUAL}

\section{1 - Introdução}

O estudo da dinâmica atual, sob a ótica da hidroquímica, foi realizado através de determinações periódicas de parâmetros químicos e físico-químicos obtidos através da amostragem de águas de nascentes, poços tubulares, nascentes e reservatórios subterrâneos ao longo da bacia de Irecê e da bacia do Rio Salitre.

Para um melhor entendimento da dinâmica corrosiva do carste do Grupo Una, foram amostrados os diferentes ambientes hidroquímicos, inicialmente designados em função da sua localização no sistema cárstico e seu ambiente de fluxo, conforme representado na figura 4.1.

As amostragens tiveram como alvo os seguintes ambientes:

- nascentes cársticas;

- poços profundos: na área de estudos existem dezenas de poços tubulares profundos administrados pela CERB (Companhia de Engenharia Rural da Bahia), que disponibilizou informações e permissão de coleta;

- escoamento superficial alogênico;

- gotejamentos em cavernas (percolação vadosa);

- águas de chuva; e

- reservatórios subterrâneos.

Onde foram determinadas as concentrações dos principais cátions e ânions e parâmetros físico-químicos.

O escoamento superficial alogênico foi amostrado cerca de $25 \mathrm{~km}$ antes da entrada nos terrenos carbonáticos, coletando-se água no início da nascente do córrego Água de Rega, no Povoado de Sonhém, município de Iraquara (foto 4.1). Apesar de existirem outros rios superficiais alogênicos, optou-se por este, em função de ser perene e um dos principais na rede de fluxo do sistema cárstico da região de Iraquara.

O fluxo freático profundo não carbonático foi amostrado em poço tubular com entradas de água e filtros nos metarenitos do Grupo Chapada Diamantina. O objetivo da coleta nestas características é o de diagnosticar a eventual influência de recarga e injeção profunda. 
FIGURA 4.1 ESQUEMA DOS AMBIENTES DE CIRCULÇÃO DE ÁGUA

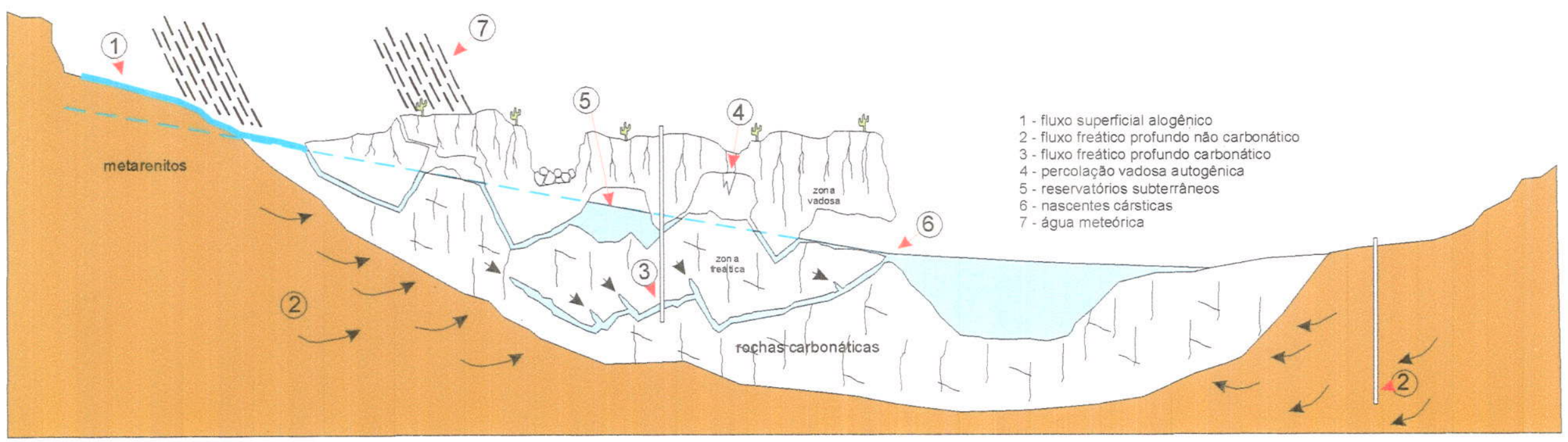


FOTO 4.1 - NASCENTE ALOGÊNICA NO POVOADO DE SONHEM - IRAQUARA-BA

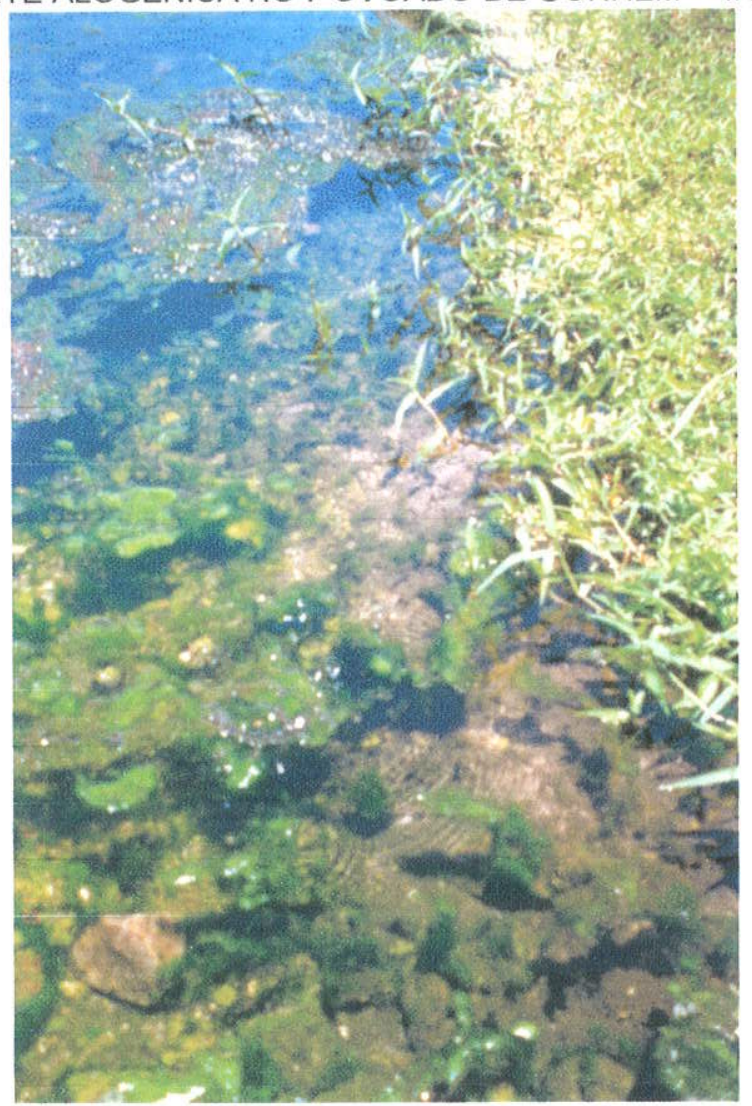

nota: detalhe da nascente - bolhas

O fluxo freático profundo carbonático foi amostrado em águas coletadas em poços tubulares. A Companhia de Engenharia Rural da Bahia - CERB, perfurou e administra centenas de poços tubulares na área de estudo. Todos estes possuem dados básicos (perfis litológicos e dados físico-químicos), que foram disponibilizados para o desenvolvimento deste projeto. De posse destas informações, foram escolhidos alguns poços que exibiam teor de sulfato elevado, bem como aqueles com localização apropriada para um entendimento regional das questões levantadas. Os poços escolhidos têm entradas de água e filtros posicionados nas rochas carbonáticas da Formação Salitre (Grupo Una).

A percolação vadosa, caracterizada por soluções que circulam no maciço rochoso nos setores acima do nível d'água, através de fraturas alimentadas por água meteórica, foram amostradas em espeleotemas ativos (foto 4.2). A análise deste mecanismo de circulação permite entender as interações químicas da interface águarocha bem como a recarga autogência. Destaca-se, nas cavidades da região de estudo, uma carência de espeleotemas com gotejamento ativo, conseqüência da escassez de chuvas na região. 
FOTO 4.2 - PERCOLAÇÃO VADOSA - GOTEJAMENTO ATIVO - GRUTA TORRINHA

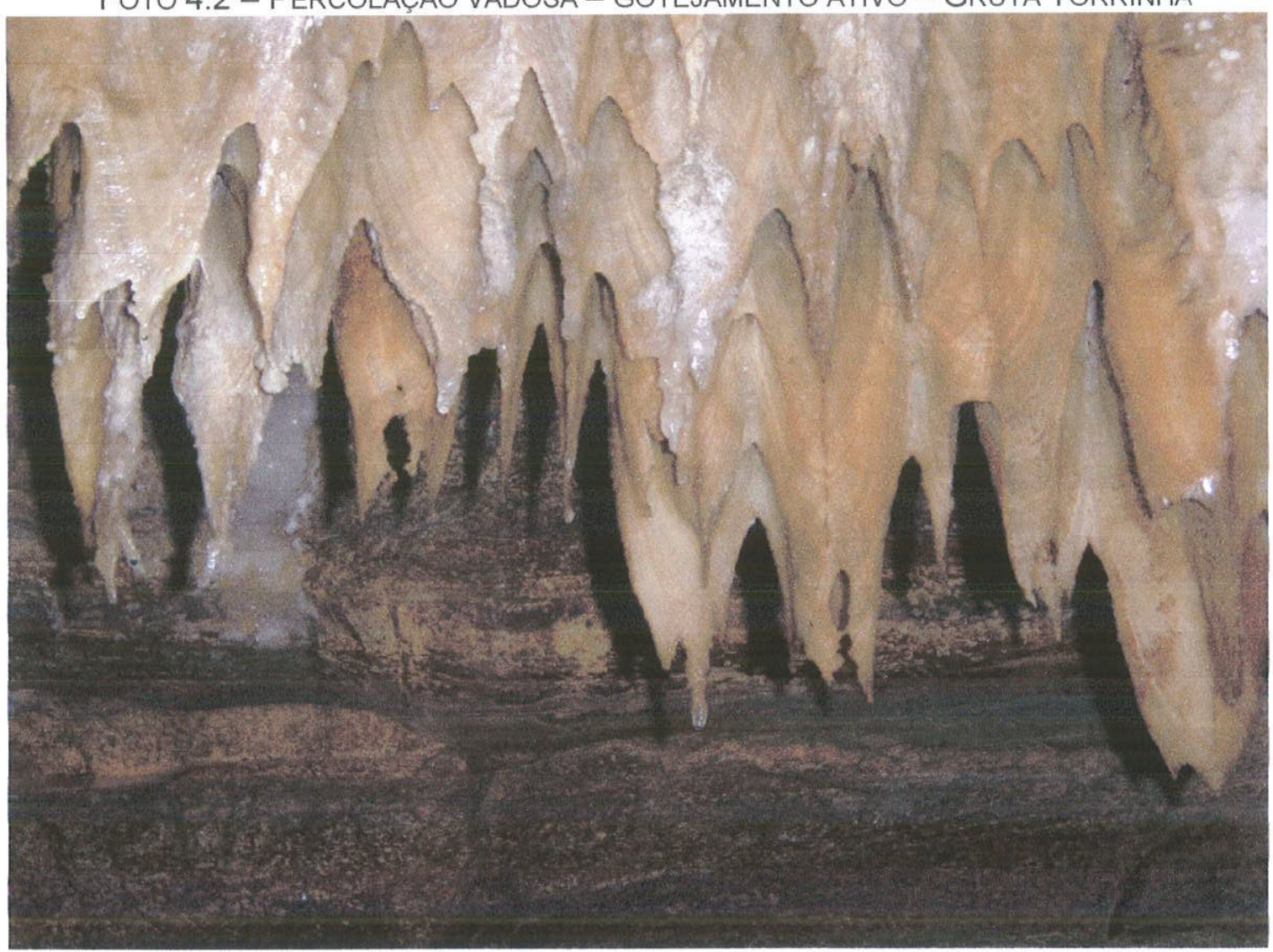

Após extensiva prospecção de gotejamentos ativos na área de estudo, selecionou-se as grutas Torrinha e Didi para amostragem, pois além de gotejamentos ativos possuem espeleotemas de gipsita em grande quantidade. Na gruta Torrinha (8500m de projeção horizontal) optou-se por um gotejamento de vazão média e outro de vazão alta. O gotejamento médio $(2,5 \mathrm{~mL} / \mathrm{min})$ está associado a uma estalactitite a 4 metros do piso, o que impossibilitou uma coleta direta, já no gotejamento rápido $(6,25 \mathrm{~mL} / \mathrm{min})$, foi possível utilizar um sistema de coleta sem que houvesse maiores interferências atmosféricas. Na gruta do Didi (623m de projeção horizontal), selecionouse um gotejamento com velocidade lenta $(1 \mathrm{~mL} / \mathrm{min})$, porém, viável de ser amostrado diretamente na estalactite associada.

Inicialmente houve a preocupação de evitar locais que pudessem ter influência antrópica na recarga logo acima do gotejamento, porém, como as grutas não dispunham de mapeamento adequado, utilizou-se informações sobre atividades externas na área sobre a caverna para avaliar a possível contaminação antrópica nos gotejamentos. A ocupação da área é tipicamente rural com habitações esparsas e em 
certas áreas as atividades de lavoura e pecuária são intensas, aspecto que aumenta as chances de contaminação.

Os reservatórios subterrâneos foram caracterizados neste estudo por águas que afloram no interior de grutas sob a forma de lagos (foto 4.3), que podem atingir dimensões com até $100 \mathrm{~m}$ de comprimento, 20 de largura e cerca de 20 de profundidade, como por exemplo, o lago da gruta Lapa Doce. É muito comum o bombeamento direto de água de grutas em vilarejos que se situam em suas proximidades. Determinadas fazendas bombeiam por volta de $40 \mathrm{mil} \mathrm{L} / \mathrm{dia}$ de água diretamente deste reservatórios para abastecimento e irrigação.

As águas das nascentes cársticas foram amostradas na "Nascente da Pratinha" (foto 4.4) e "Nascente do Rio Pacui" (fotos 4.5 e 4.6). A Nascente da Pratinha destacase pelo volume de água e pela regularidade das vazões ao longo do ano. Para garantir a boa qualidade das amostragens desta nascente uma vez que recebe extensiva visitação turística, optou-se por coletar as águas na extremidade 100 à montante no ponto denominado gruta Azul.

As precipitações pluviométricas na região são escassas e, por este motivo, foram obtidas amostras de 7 eventos de chuva. Devido a este fato, utilizou-se também dados analíticos de chuvas de trabalhos anteriores.

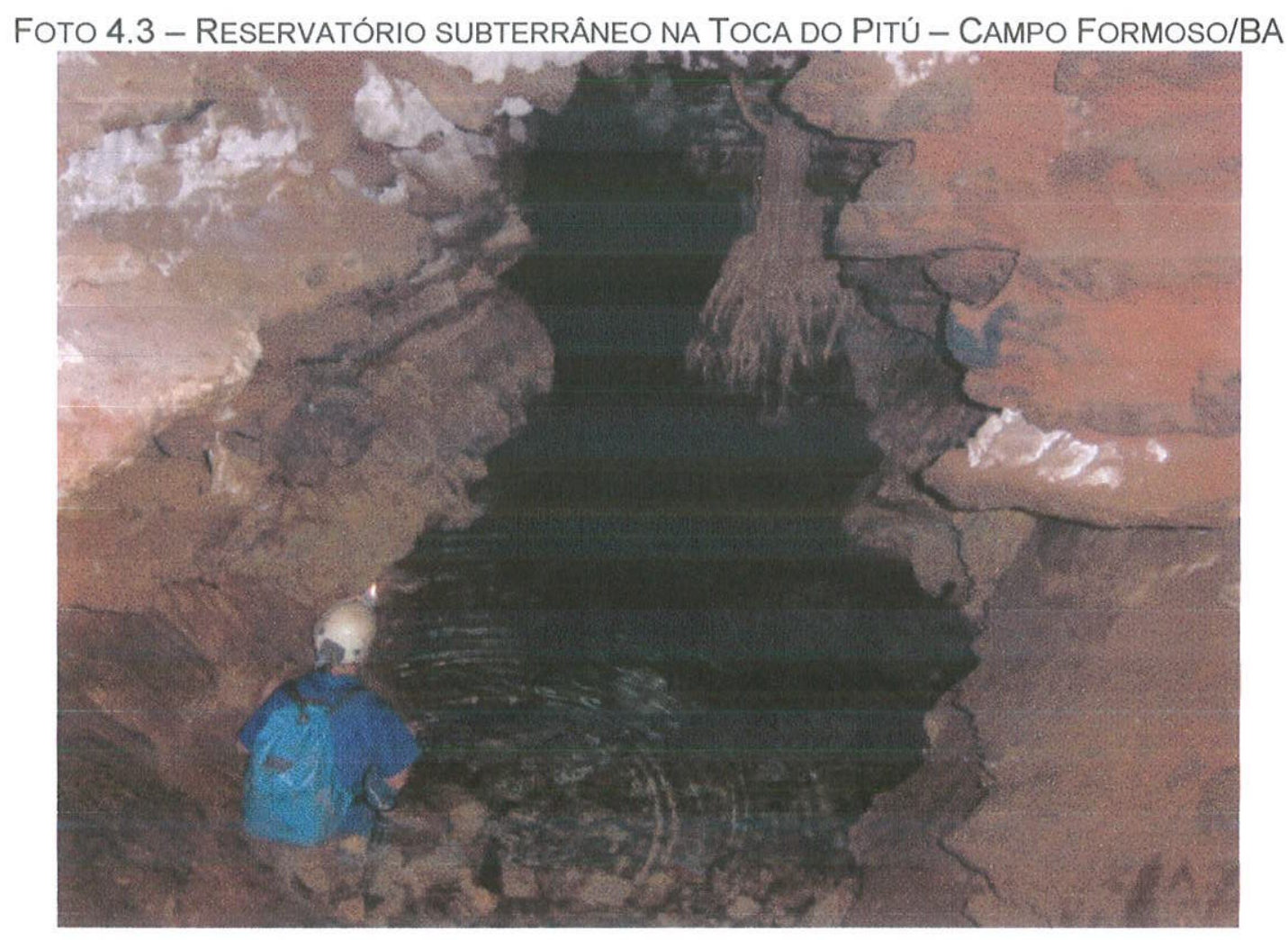


FOTO 4.4 - NASCENTE DA PRATINHA - IRAQUARA/BA

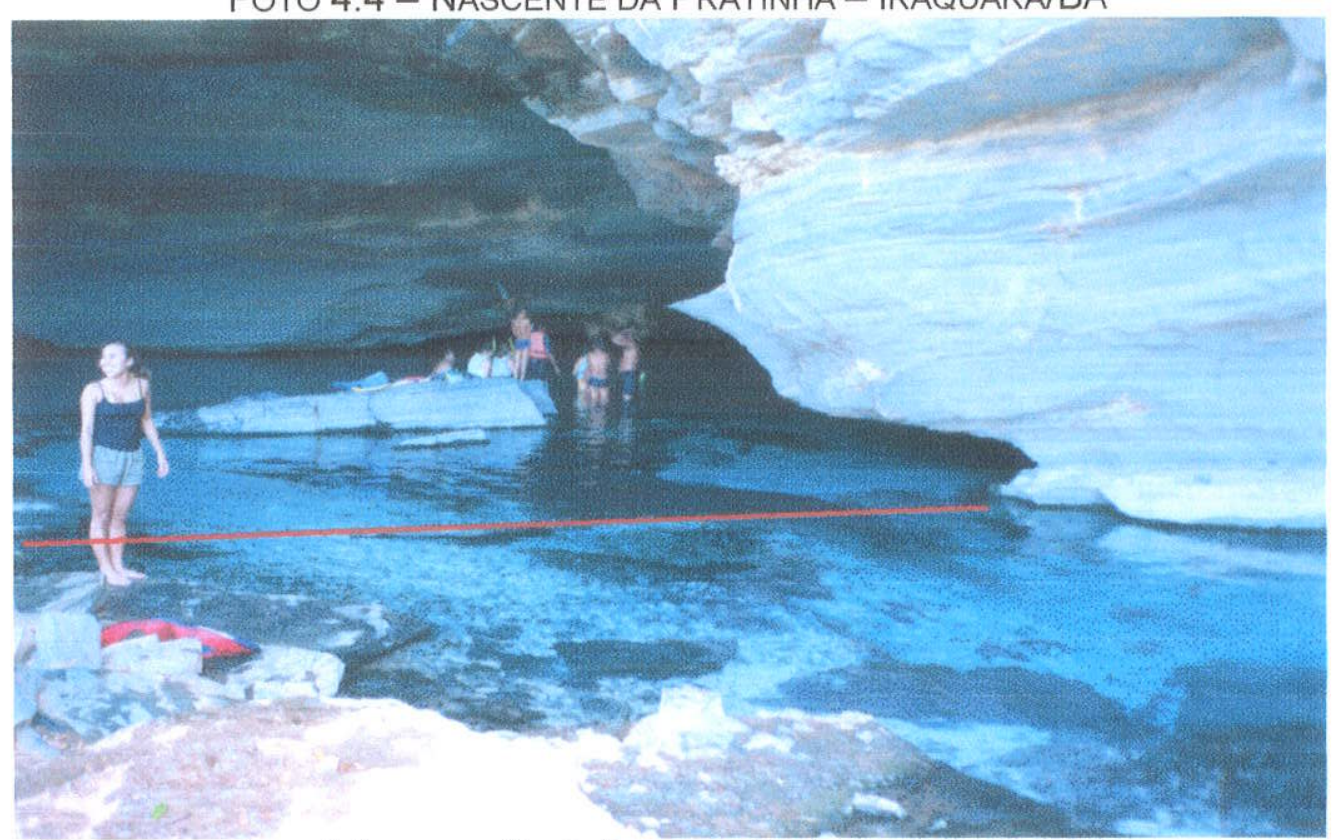

nota: a linha vermelha indica a seção de medição de vazão

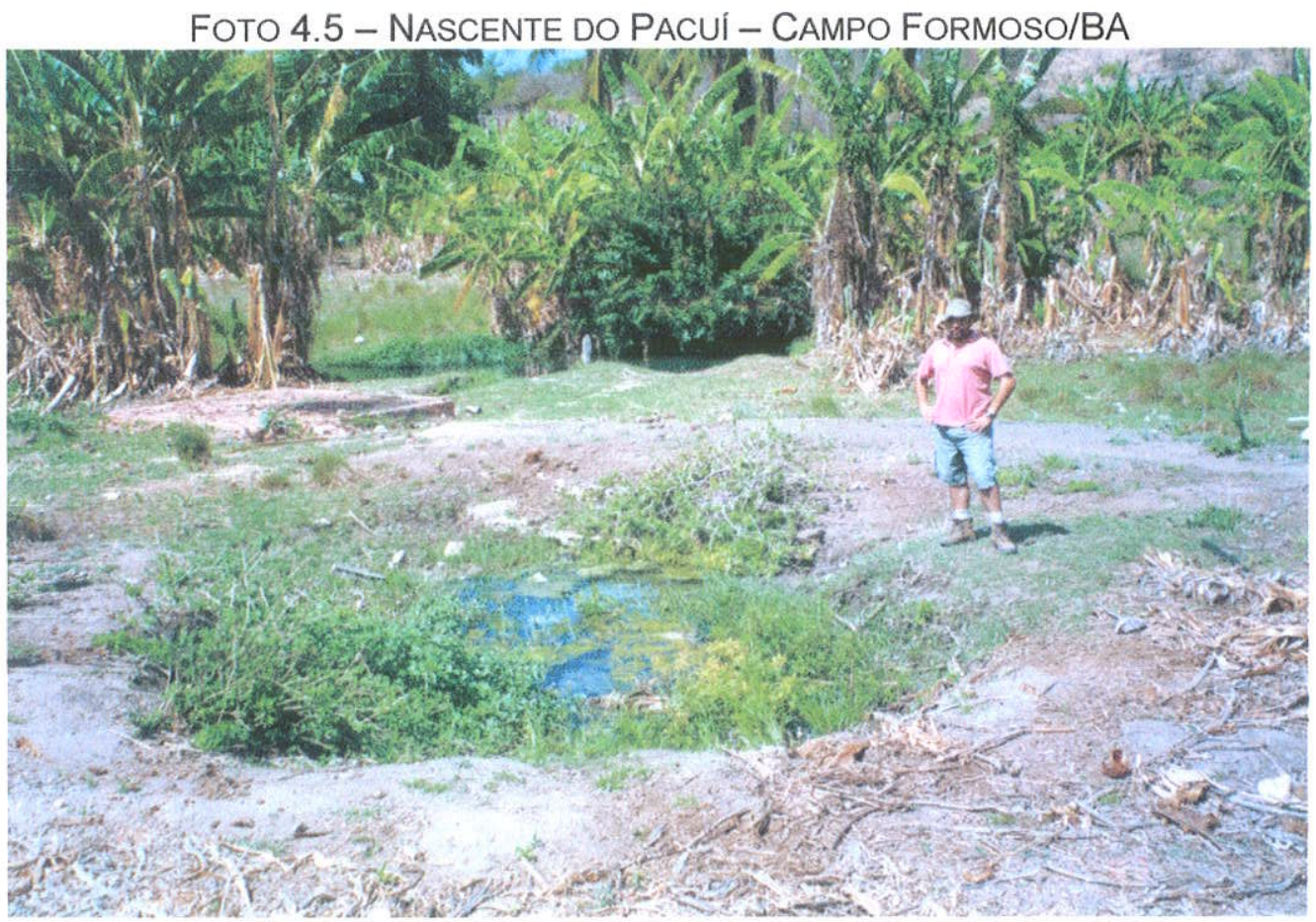

nota: a nascente do rio Pacuí é composta por várias ressurgências, como a exibida nesta foto, que culminam com o curso d'água ilustrado na figura 4.6 


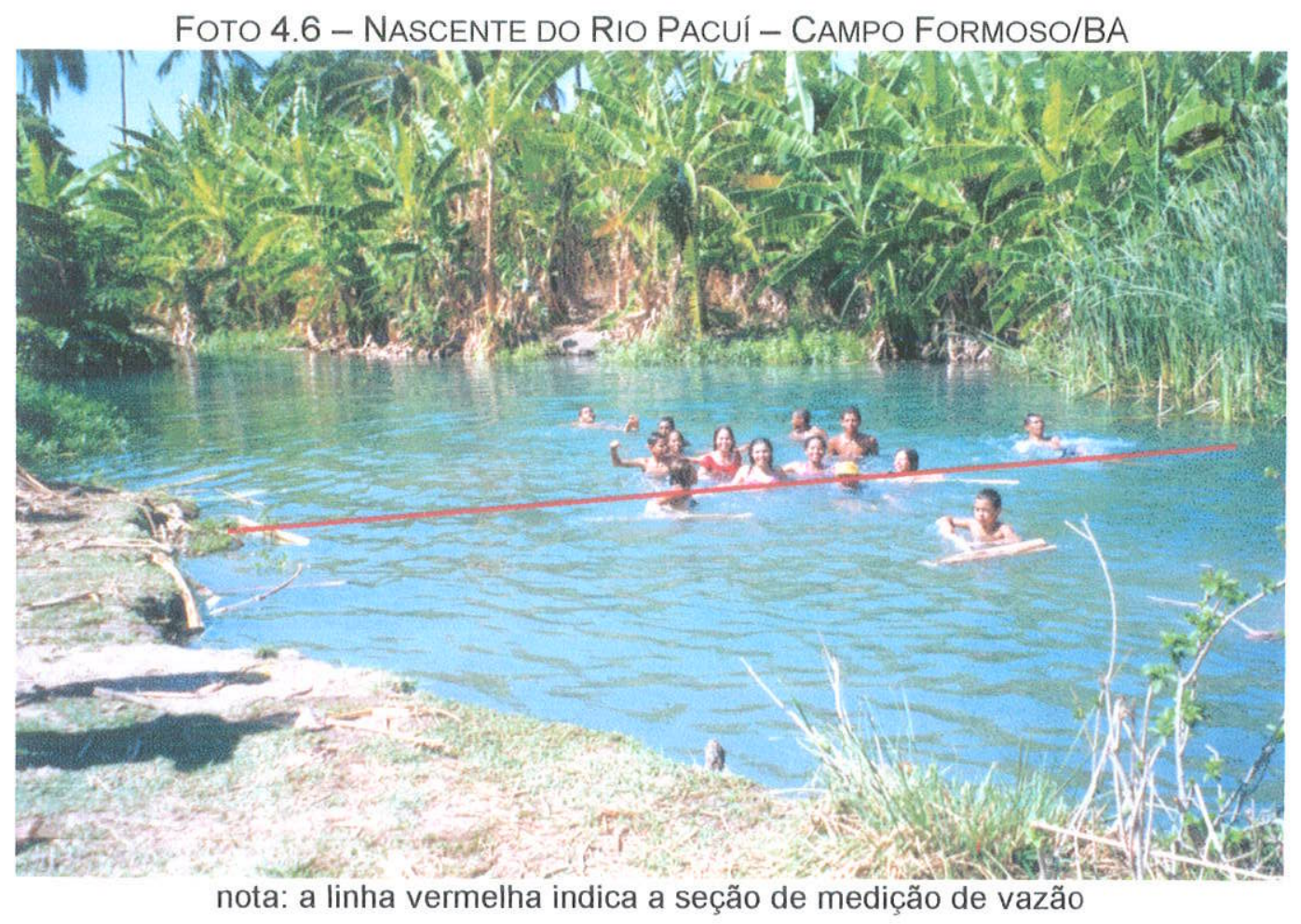

\section{2 - Parâmetros hidroquímicos derivados}

\subsection{1 - Dureza Total}

A dureza em água é devida à presença de compostos de cálcio, magnésio, bicarbonato, carbonato, cloreto e sulfato (Garrels \& Christ,1965), sendo determinada através de cálculos efetuados com as concentrações de sais alcalino terrosos contidos na água. A dureza total, expressa em mg/L equivalentes a $\mathrm{CaCO}_{3}$, é a soma entre a dureza temporária $\left(D_{t}\right)$ (que pode ser eliminada com fervura de água) e dureza permanente $\left(\mathrm{D}_{\mathrm{p}}\right)$ (de não carbonatos $-\mathrm{Cl}^{-}, \mathrm{SO}_{4}{ }^{2-}$ ).

$$
\mathrm{DT}=\mathrm{D}_{\mathrm{t}}+\mathrm{D}_{\mathrm{p}}
$$

Neste estudo a dureza total foi calculada pelo software AquaChem (Waterloo Hydrogeologic), que utiliza as premissas de cálculo citadas. Os valores obtidos encontram-se na tabela 4.1. 


\begin{tabular}{|c|c|c|c|c|c|c|c|c|c|c|c|c|c|c|c|c|c|c|c|c|c|}
\hline \multirow[b]{2}{*}{ fácies } & \multirow[b]{2}{*}{ ref } & \multicolumn{5}{|c|}{ parâmetros físico-quimicos } & \multicolumn{10}{|c|}{ parâmetros quimicos medidos } & \multirow[b]{2}{*}{$\begin{array}{l}\mathrm{SO}_{4}{ }^{2-} \\
\mathrm{mg} / \mathrm{L}\end{array}$} & \multirow[b]{2}{*}{$\begin{array}{l}\mathrm{HCO}_{3}- \\
\mathrm{mg} / \mathrm{L}\end{array}$} & \multicolumn{3}{|c|}{ Dureza } \\
\hline & & $\mathrm{pH}$ & $\begin{array}{l}\text { Eh } \\
\text { (mv) }\end{array}$ & $\begin{array}{c}\mathrm{T} \\
\left({ }^{\circ} \mathrm{C}\right)\end{array}$ & $\begin{array}{l}\text { CE } \\
\text { (S) }\end{array}$ & $\begin{array}{l}\mathrm{Na}^{+} \\
\mathrm{mg} / \mathrm{L}\end{array}$ & $\begin{array}{c}\mathrm{K}^{+} \\
\mathrm{mg} / \mathrm{L}\end{array}$ & $\begin{array}{l}\mathrm{Ca}^{2+} \\
\mathrm{mg} / \mathrm{L}\end{array}$ & $\begin{array}{l}\mathrm{Mg}^{2+} \\
\mathrm{mg} / \mathrm{L}\end{array}$ & $\begin{array}{l}\mathrm{Ba}^{2+} \\
\mathrm{mg} / \mathrm{L}\end{array}$ & $\begin{array}{l}\mathrm{Fe}^{2+} \\
\mathrm{mg} / \mathrm{L}\end{array}$ & $\begin{array}{l}\mathrm{Sr}^{2+} \\
\mathrm{mg} / \mathrm{L}\end{array}$ & $\begin{array}{l}\mathrm{Zn}^{2+} \\
\mathrm{mg} / \mathrm{L}\end{array}$ & $\begin{array}{c}\mathrm{F} \cdot \\
\mathrm{mg} / \mathrm{L}\end{array}$ & $\begin{array}{c}\mathrm{Cl} \\
\mathrm{mg} / \mathrm{L}\end{array}$ & $\begin{array}{l}\mathrm{NO}_{3}- \\
\mathrm{mg} / \mathrm{L}\end{array}$ & & & $\begin{array}{l}\mathrm{Al}^{3+} \\
\mathrm{mg} / \mathrm{L}\end{array}$ & $\begin{array}{l}\text { Total } \\
\mathrm{mg} / \mathrm{L} \\
\mathrm{CaCO}_{3}\end{array}$ & $\mathrm{PCO}_{2}$ \\
\hline \multirow[t]{3}{*}{1} & $\begin{array}{l}\max \\
\text { média }\end{array}$ & $\begin{array}{l}4.98 \\
4.79\end{array}$ & $\begin{array}{l}344.00 \\
264.75\end{array}$ & $\begin{array}{l}24.40 \\
19.53\end{array}$ & $\begin{array}{l}50.00 \\
45.50\end{array}$ & $\begin{array}{l}4.72 \\
4.28\end{array}$ & $\begin{array}{c}1.01 \\
0.93\end{array}$ & $\begin{array}{l}1.37 \\
0.84\end{array}$ & $\begin{array}{l}1.06 \\
0.93\end{array}$ & $\begin{array}{l}0.06 \\
0.04\end{array}$ & $\begin{array}{l}0.22 \\
0.07\end{array}$ & $\begin{array}{l}0.01 \\
0.01\end{array}$ & $\begin{array}{l}0.07 \\
0.02\end{array}$ & $\begin{array}{l}0.02 \\
0.01\end{array}$ & $\begin{array}{c}11.23 \\
9.58\end{array}$ & $\begin{array}{l}2.68 \\
2.39\end{array}$ & $\begin{array}{l}0.63 \\
0.57\end{array}$ & $\begin{array}{l}6.10 \\
2.90\end{array}$ & $\begin{array}{l}0.06 \\
0.02\end{array}$ & $\begin{array}{l}7.84 \\
5.99\end{array}$ & $\begin{array}{c}0.59 \\
0.56\end{array}$ \\
\hline & $\min$ & 4.64 & 119.00 & 15.00 & 42.00 & 3.46 & 0.88 & 0.63 & 0.86 & 0.03 & 0.00 & 0.00 & 0.00 & 0.00 & 8.56 & 1.72 & 0.50 & 0.00 & 0.01 & 5.16 & 0.51 \\
\hline & CV (\%) & 3.15 & 37.79 & 25.43 & 7.51 & 13.30 & 6.19 & 41.88 & 9.41 & 29.61 & 157.67 & 53.98 & 141.55 & 76.59 & 13.05 & 19.03 & 10.32 & 89.94 & 124.02 & 20.74 & 6.91 \\
\hline \multirow{4}{*}{2} & $\max$ & 6.99 & 226.00 & 24.10 & 383.00 & 16.40 & 2.90 & 22.20 & 11.30 & 0.47 & 2.66 & 0.07 & 0.17 & 0.39 & 48.49 & 0.50 & 3.31 & 91.53 & 0.08 & 102.58 & 0.49 \\
\hline & média & 6.83 & 33.00 & 22.14 & 312.20 & 14.95 & 2.61 & 18.61 & 10.67 & 0.43 & 2.48 & 0.06 & 0.08 & 0.09 & 42.86 & 0.15 & 2.37 & 79.32 & 0.02 & 91.00 & 0.46 \\
\hline & $\min$ & 6.68 & -47.00 & 19.00 & 282.00 & 12.50 & 2.38 & 16.80 & 8.78 & 0.36 & 2.21 & 0.04 & 0.02 & 0.00 & 38.49 & 0.03 & 1.42 & 73.22 & 0.00 & 84.83 & 0.44 \\
\hline & CV (\%) & 1.92 & 333.26 & 11.19 & 13.27 & 9.81 & 9.78 & 12.00 & 9.97 & 10.53 & 9.26 & 14.66 & 93.52 & 181.62 & 9.49 & 127.13 & 30.01 & 10.88 & 161.63 & 7.51 & 4.28 \\
\hline \multirow{4}{*}{3} & $\max$ & 8.06 & 275.00 & 32.00 & 1763.00 & 129.00 & 11.70 & 352.00 & 167.00 & 0.29 & 1.68 & 3.92 & 0.61 & 2.53 & 387.34 & 108.30 & 824.06 & 518.67 & 0.07 & 83 & 0.62 \\
\hline & média & 6.87 & 175.00 & 24.85 & 1000.14 & 61.80 & 6.38 & 175.51 & 68.85 & 0.12 & 0.12 & 1.48 & 0.13 & 0.98 & 190.52 & 28.45 & 204.50 & 359.08 & 0.01 & 725.63 & 0.54 \\
\hline & $\min$ & 6.25 & 0.00 & 16.80 & 2.43 & 17.70 & 1.72 & 78.02 & 13.20 & 0.02 & 0.00 & 0.13 & 0.01 & 0.20 & 66.45 & 0.87 & 10.22 & 195.26 & 0.00 & 284.50 & $\begin{array}{l}0.30 \\
10.2\end{array}$ \\
\hline & CV (\%) & 4.62 & 46.16 & 14.39 & 56.82 & 54.17 & 47.06 & 46.37 & 68.51 & 68.52 & 285.07 & 93.93 & 130.47 & 72.61 & 53 & 108.72 & 0 & 19 & 156.92 & 52.79 & 9 \\
\hline \multirow{4}{*}{4} & $\max$ & 8.00 & 276.00 & 25.00 & 12.63 & 1340.00 & 12.60 & 883.16 & 405.00 & 0.16 & 0.02 & 2.80 & 0.10 & 6.69 & 4460.80 & 167.70 & 636.70 & 152.55 & 0.06 & 3804.65 & 0.37 \\
\hline & média & 7.74 & 160.31 & 22.67 & 6.89 & 554.38 & 4.20 & 552.85 & 211.35 & 0.09 & 0.01 & 1.50 & 0.03 & 2.90 & 2240.31 & 108.93 & 305.09 & 99.56 & 0.02 & 2262.74 & 0.31 \\
\hline & $\min$ & 7.06 & 0.00 & 20.40 & 2.88 & 99.52 & 1.11 & 297.00 & 92.92 & 0.04 & 0.00 & 0.35 & 0.00 & 0.92 & 766.30 & 40.43 & 84.01 & 36.61 & 0.01 & 1234.17 & $\begin{array}{c}0.24 \\
11.6\end{array}$ \\
\hline & CV (\%) & 4.00 & 50.89 & 6.45 & 60.29 & & 76.40 & 42.33 & 63.21 & 50.23 & 109.20 & 59.87 & 98.80 & 71.38 & 68.00 & 44.69 & 65.96 & 41.61 & 87.52 & 49.72 & 9 \\
\hline \multirow{4}{*}{ 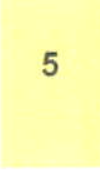 } & $\max$ & 7.39 & 282.00 & 27.60 & 731.00 & 13.90 & 4.97 & 145.80 & 32.40 & 0.64 & 0.03 & 0.73 & 0.08 & 0.24 & 40.59 & 39.41 & 32.20 & 411 & 0.05 & 451.04 & 0.57 \\
\hline & média & 7.09 & 191.50 & 22.39 & 613.14 & 10.38 & 3.65 & 90.36 & 23.79 & 0.30 & 0.01 & 0.31 & 0.02 & 0.12 & 31.07 & 8.16 & 17.79 & 305.10 & 0.01 & 325.02 & 0.50 \\
\hline & $\min$ & 6.71 & 1.00 & 15.10 & 530.00 & 5.67 & 2.53 & 64.00 & 16.70 & 0.09 & 0.00 & 0.09 & 0.00 & 0.05 & 25.42 & 0.34 & 5.50 & 207.47 & 0.00 & 262.17 & 0.44 \\
\hline & CV (\%) & 2.93 & 44.59 & 13.64 & 11.32 & 22.77 & 21.08 & 29.19 & 18.58 & 63.91 & 125.55 & 65.72 & 132.05 & 44.51 & 13.97 & 133.85 & 52.03 & 23.77 & 134.38 & 18.41 & 7.97 \\
\hline \multirow{4}{*}{6} & $\max$ & 7.60 & 521.00 & 29.20 & 598.00 & 15.40 & 4.97 & 76.80 & 28.00 & 0.28 & 0.03 & 0.37 & 0.86 & 0.18 & 43.36 & 55.52 & 27.60 & 297.47 & 0.05 & 302.04 & 0.52 \\
\hline & média & 7.27 & 171.33 & 23.87 & 492.67 & 12.66 & 4.33 & 67.70 & 24.86 & 0.22 & 0.01 & 0.22 & 0.11 & 0.09 & 32.20 & 10.42 & 19.30 & 246.96 & 0.01 & 272.84 & 0.47 \\
\hline & $\min$ & 6.88 & -240.00 & 18.80 & 68.00 & 10.35 & 3.61 & 60.00 & 22.20 & 0.15 & 0.00 & 0.12 & 0.00 & 0.01 & 26.59 & 3.98 & 13.78 & 219.67 & 0.00 & 250.00 & 0.41 \\
\hline & CV (\%) & 3.20 & 115.71 & 16.04 & 33.06 & 16.87 & 10.56 & 7.69 & 8.38 & 26.46 & 125.64 & 48.08 & 248.97 & 50.53 & 17.12 & 162.41 & 31.47 & 11.00 & 128.99 & 7.23 & 8.15 \\
\hline
\end{tabular}

fácies 1 - escoamento alogênico; fácies 2 - fluxo freático profundo não

carbonático; fácies 3 - fluxo freático profundo carbonático; fácies 4 - percolação

Nota: Índice de Saturação na tabela 4.2

vadoa autocênica; fácies 5 - reservatórios subterrâneos; fácies 6 - nascentes

cársticas 


\subsection{2 - Condutividade elétrica e dureza total}

A relação entre condutividade elétrica e dureza total é muito útil para avaliar o teor de sais dissolvidos e o conseqüente grau de saturação das águas. Obteve-se a seguinte função linear $(n=76)$ com os resultados analiticos das amostras (figura 4.3):

$$
y=3,22526 x-551,50 \quad R^{2}=0,98069
$$

\section{FIGURA 4.2 - RELAÇÃO ENTRE CONDUTIVIDADE ELÉTRICA E DUREZA TOTAL DA AMOSTRAGEM DA ÁGUA}

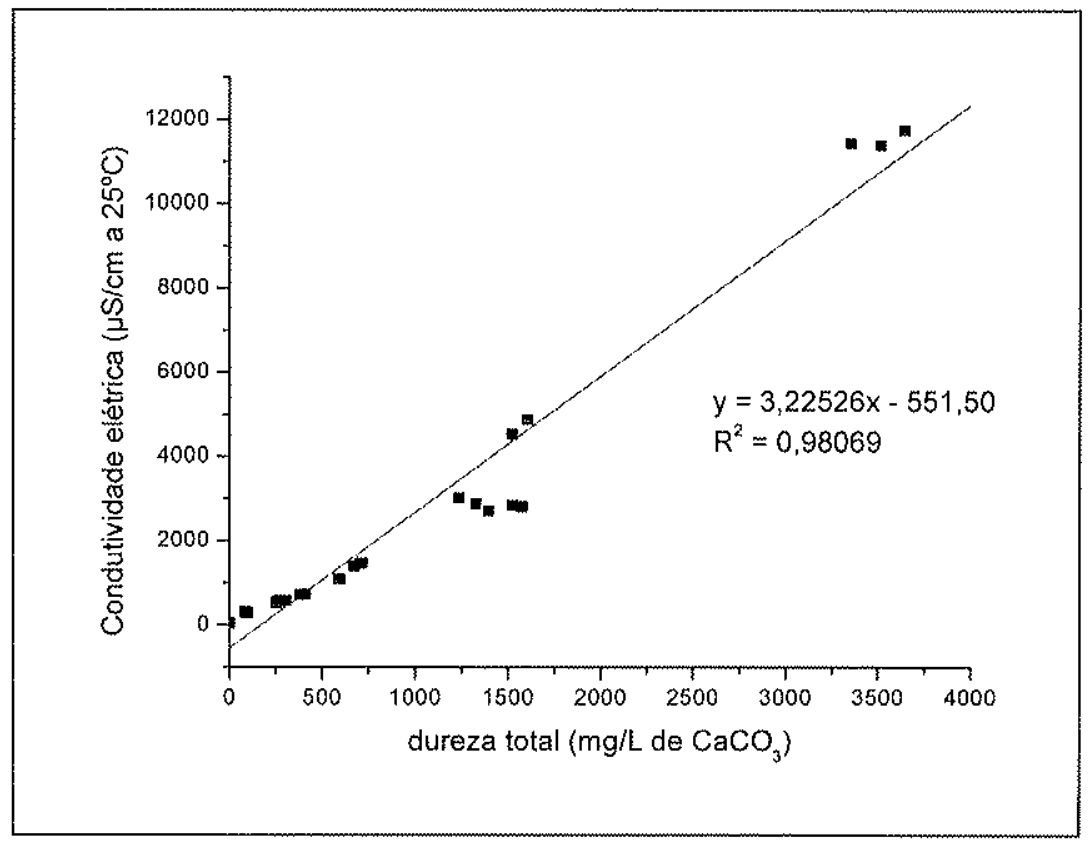

\subsection{3 - Índice de Saturação}

O índice de saturação expressa quanto uma água natural desvia do estado de equilibrio (White, 1988), e tem uma relação direta com a concentração de $\mathrm{CO}_{2}$ dissolvido na água, pois este é que controla o equilíbrio do $\mathrm{CaCO}_{3}$ em solução. Em um ambiente cárstico, sobretudo na região de estudo, não está presente apenas o carbonato sob a forma de calcita, mas também aragonita e dolomita $\left(\mathrm{CaMg}\left(\mathrm{CO}_{3}\right)_{2}\right)$.

O valor do Índice de Saturação irá indicar se a água e corrosiva ou incrustante e, desta forma, sua determinação está relacionada aos produtos de solubilidade dos compostos que fazem parte do sistema. Neste estudo foram calculados os índices de saturação para calcita, dolomita e gipsita, que são definidos, respectivamente pelas relações: 


$\begin{array}{ccc}\text { calcita } & \text { dolomita } & \text { gipsita } \\ S I_{\mathrm{c}}=\log \frac{\mid \mathrm{IAP}}{\mathrm{K}_{\mathrm{c}}} & \left.S\right|_{\mathrm{d}}=\log \frac{\left(\underline{\operatorname{IAP}}_{\mathrm{d}}\right)^{2}}{\left(\mathrm{~K}_{\mathrm{d}}\right)^{2}} & \left.\mathrm{SI}\right|_{\mathrm{g}}=\log \frac{\mid \mathrm{IAP}}{\mathrm{K}_{\mathrm{g}}}\end{array}$

Onde:

- $\mid A P_{c}$ é o produto da atividade iônica $\left[\mathrm{Ca}^{2+}\right]\left[\mathrm{CO}_{3}{ }^{2-}\right]$ em solução e $\mathrm{K}_{c}$ e o produto da solubilidade da calcita (dado tabelado)

- IAPd é o produto da atividade iônica $\left[\mathrm{Ca}^{2+}\right]\left[\mathrm{Mg}^{2+}\right]\left[\mathrm{CO}_{3}{ }^{2-}\right]$ em solução e $\mathrm{K}_{d}$ e o produto da solubilidade da calcita (dado tabelado)

- $\mid A P_{\mathrm{g}}$ é o produto da atividade iônica $\left[\mathrm{Ca}^{2+}\right]\left[\mathrm{SO}_{4}{ }^{2 n}\right]$ em solução e $\mathrm{K}_{\mathrm{g}}$ e o produto da solubilidade da calcita (dado tabelado)

Segundo Langmuir (1971), nestas expressões, quando IAP = K, o índice de saturação é igual a zero, isto é, a água está em perfeito equilíbrio com o mineral em solução, ou seja, a solução está saturada e não ocorre dissolução ou precipitação. Assim, valores positivos no resultado do cálculo do índice de saturação indicam soluções supersaturadas, propensas à deposição, e valores negativos representam soluções insaturadas em relação aos minerais dissolvidos, sendo, desta forma, predispostas a corrosão.

Para os cálculos do índice da saturação da calcita e dolomita, deve-se ter uma atenção especial na determinação do $\mathrm{pH}$ no campo, pois $\left[\mathrm{CO}_{3}{ }^{2}\right]$ é de difícil medição e é obtido através da determinação do $\mathrm{pH}$ e do $\mathrm{HCO}_{3}{ }^{-}$. Nas águas do presente estudo, a espécie carbonática dominante é $\mathrm{O} \mathrm{HCO}_{3}{ }^{-}$. Desta forma, para permitir o cálculo do índice de saturação, por titulometria, determina-se, no campo, a concentração de $\mathrm{HCO}_{3}{ }^{-} \mathrm{O} \mathrm{pH}$ torna-se importante, pois uma incerteza de $\pm 0,05$ produz um erro de 0,1 no índice de saturação Langmuir (op.cit).

Assim:

para calcita

$$
\mathrm{SI}_{\mathrm{C}}=\log \frac{\mid \mathrm{AP}}{\mathrm{K}_{\mathrm{C}}}=\frac{\left[\mathrm{Ca}^{2+}\right]\left[\mathrm{CO}_{3}{ }^{2-}\right]}{\mathrm{KC}}, \text { mas }\left[\mathrm{CO}_{3}{ }^{2-}\right]=\frac{\left[\mathrm{HCO}_{3}{ }^{-}\right] K_{2}}{\left[\mathrm{H}^{+}\right]} \operatorname{logo}
$$




$$
\begin{aligned}
& \mathrm{SI}_{\mathrm{c}}=\frac{\log \left[\frac{\left.\mathrm{Ca}^{2+}\right]\left[\mathrm{HCO}_{3}{ }^{-}\right] \mathrm{K}_{2}}{[\mathrm{H+}+\mathrm{Kc}}\right.}{\mathrm{SI}_{\mathrm{C}}}=\log \left[\mathrm{Ca}^{2+}\right]+\log \left[\mathrm{HCO}_{3}{ }^{-}\right]+\mathrm{pH}-\mathrm{pK} 2+\mathrm{pK}_{\mathrm{c}}
\end{aligned}
$$

para dolomita

$$
S I_{d}=\log \left[\mathrm{Ca}^{2+}\right]+\log \left[\mathrm{Mg}^{2+}\right]+2 \log \left[\mathrm{HCO}_{3}\right]+2 \mathrm{pH}-2 \mathrm{pK} 2+\mathrm{pK}_{\mathrm{d}}
$$

onde:

$\left[\mathrm{Ca}^{2+}\right]$ e $\left[\mathrm{Mg}^{2+}\right]$ analisados por ICP-AES

$\left[\mathrm{HCO}_{3}\right]$ analisado por titulometria acidimétrica (em laboratório de campo)

$\mathrm{pH}$ - medido em campo

pK e pK2 obtidos em tabela (Ford \& Williams, 1989) e embutidos no programa utilizado

No presente estudo utilizou-se o programa AquaChem $\otimes$, que utiliza as bases conceituais acima citadas para calcular os índices de saturação em calcita, dolomita e gipsita das águas amostradas, conforme se observa na tabela 4.2.

\subsection{4 - Pressão parcial de $\mathrm{CO}_{2}$}

A solubilidade de calcita e dolomita por dissociação em água pura ou deionizada é muito lenta (Ford \& Williams, 1989) e, neste sentido, sobretudo em um ambiente cárstico, sabe-se que o aumento da concentração de $\mathrm{H}^{+}$, oriundo da acidulação da água, é um fator predominante na corrosão das rochas carbonáticas.

A produção de ácido carbônico é um importante fator para o incremento de $\mathrm{H}^{+}$ no sistema que, por sua vez, aumenta a corrosão das rochas carbonáticas (Bögli, 1980). Cabe ressaltar, inclusive por se tratar do escopo principal deste estudo, que o fornecimento de $\mathrm{H}^{+}$pode ser dado por outros ácidos, além do carbônico. Assim, o conhecimento da $\mathrm{pCO}_{2}$ também é importante mesmo quando o $\mathrm{H}_{2} \mathrm{CO}_{3}$ não é o principal agente corrosivo do carste, pois a interação ácida em rochas carbonáticas gera $\mathrm{CO}_{2}$. 
TABELA 4.2 - ÍNDICE DE SATURAÇÃO NAS FÁCIES HIDROQUIMICAS Índice de Saturação

\begin{tabular}{|c|c|c|c|c|c|}
\hline fácies & & Aragonita & Calcita & Dolomita & Gipsita \\
\hline \multirow{4}{*}{1} & $\max$ & -5.89 & -5.74 & -11.38 & -5.26 \\
\hline & média & -6.22 & -6.07 & -11.85 & -5.43 \\
\hline & $\min$ & -6.39 & -6.24 & -12.15 & -5.52 \\
\hline & CV (\%) & 4.64 & 4.75 & 3.48 & 2.18 \\
\hline \multirow{4}{*}{2} & $\max$ & -1.44 & -1.29 & -2.50 & -3.47 \\
\hline & média & -1.58 & -1.43 & -2.79 & -3.65 \\
\hline & $\min$ & -1.78 & -1.64 & -3.19 & -3.89 \\
\hline & CV (\%) & 8.14 & 9.26 & 9.06 & 4.47 \\
\hline \multirow{4}{*}{3} & $\max$ & 0.41 & 0.56 & 1.23 & -0.50 \\
\hline & média & -0.12 & 0.02 & -0.08 & -1.51 \\
\hline & $\min$ & -0.66 & -0.52 & -1.57 & -2.47 \\
\hline & CV (\%) & 195.27 & 1144.92 & 732.10 & 38.64 \\
\hline \multirow{4}{*}{4} & & 0.92 & 1.07 & 2.16 & -0.55 \\
\hline & média & 0.41 & 0.56 & 0.99 & -0.95 \\
\hline & $\min$ & -0.63 & -0.49 & -1.31 & -1.35 \\
\hline & CV (\%) & 116.25 & 86.08 & 110.94 & 32.77 \\
\hline \multirow{4}{*}{5} & $\max$ & 0.15 & 0.29 & 0.53 & -2.05 \\
\hline & média & -0.17 & -0.02 & -0.30 & -2.36 \\
\hline & $\min$ & -0.37 & -0.23 & -0.87 & -2.74 \\
\hline & CV $(\%)$ & 83.24 & 571.18 & 114.14 & 9.14 \\
\hline \multirow{4}{*}{6} & $\max$ & 0.14 & 0.28 & 0.46 & -2.17 \\
\hline & média & -0.14 & 0.00 & -0.10 & -2.35 \\
\hline & $\min$ & -0.52 & -0.37 & -0.91 & -2.50 \\
\hline & $\mathrm{CV}(\%)$ & 143.87 & - & 441.68 & 6.23 \\
\hline
\end{tabular}

fácies 1 - escoamento alogênico; fácies 2 - fluxo freático profundo não carbonático; fácies 3 - fluxo freático profundo carbonático; fácies 4 - percolação vadosa autogênica; fácies 5 reservatórios subterrâneos; fácies 6 - nascentes cársticas 
Neste sentido, a pressão parcial de $\mathrm{CO}_{2}$ é um parâmetro hidroquímico importante, pois reflete a proveniência e história das águas cársticas (Ford \& Williams, 1989) e representa a pressão de uma fase gasosa de $\mathrm{CO}_{2}$ coexistente e em perfeito equilibrio com a água analisada (White,1988).

A pressão parcial de $\mathrm{CO}_{2}$ é obtida pela expressão:

$$
\mathrm{pCO}_{2}=\frac{\left[\mathrm{HCO}_{3}^{-}\right]\left[\mathrm{H}^{+}\right]}{\mathrm{K}_{1} \cdot \overrightarrow{\mathrm{KCO}_{2}}} \quad \text { (Ford \& Wiliams, 1989) }
$$

onde $=\left[\mathrm{HCO}_{3}{ }^{-}\right]$é a atividade iônica do ânion $\mathrm{HCO}_{3}{ }^{-}$, obtida por titulação acidimétrica da amostra de água, $\left[\mathrm{H}^{+}\right]$é o valor negativo do $\mathrm{pH}, \mathrm{K} 1$ é a constante de dissociação do ácido carbônico e $\mathrm{KCO}_{2}$ é a constante de hidratação do $\mathrm{CO}_{2}$ (Ford \& Williams, 1989)(as constantes descritas são obtidas em tabelas).

Os valores de $\mathrm{pCO}_{2}$ obtidos neste estudo foram calculados utilizando o software Microsoft Excel, segundo base conceitual descrita em Ford \& Williams (op.cit) e estão dispostos na tabela 4.1.

\subsection{5 - Erro do Balanço lônico}

Seguindo recomendações expressas em Ford \& Williams (op.cit) foram calculados os erros dos balanços iônicos, que pode indicar problemas analíticos ou a ausência de algum parâmetro essencial nas análises. O Erro do Balanço lônico (IBE), expresso em porcentagem, é dado pela expressão:

$$
\mathrm{IBE}=\frac{\sum m_{i} \cdot z_{i} \text { (cátions) }-\sum m_{i} z_{i} \text { (ânions) }}{\sum m_{i} \cdot z_{i} \text { (cátions) }+\sum m_{i} z_{i} \text { (ånions) }} \times 100
$$

onde $m_{i}$ é a concentração molar dos íons e $z_{i}$ é a valência dos respectivos ions. Segundo Ford \& Williams (op.cit.) são admissiveis erros em amostras de até $10 \%$, sendo que para valores acima deste percentual devem ser analisadas as causas do desvio. Necessariamente um percentual alto não indica amostra inválida, pois depende das condições do ambiente que se analisa.

Os valores dos erros do balanço iônico deste trabalho foram calculados pelo software AquaChem. No conjunto de análises realizadas, observa-se que todos 
possuem IBE dentro de valores admissiveis. A figura 4.3 ilustra os valores médios e suas variações máximas e mínimas para cada ponto de amostragem

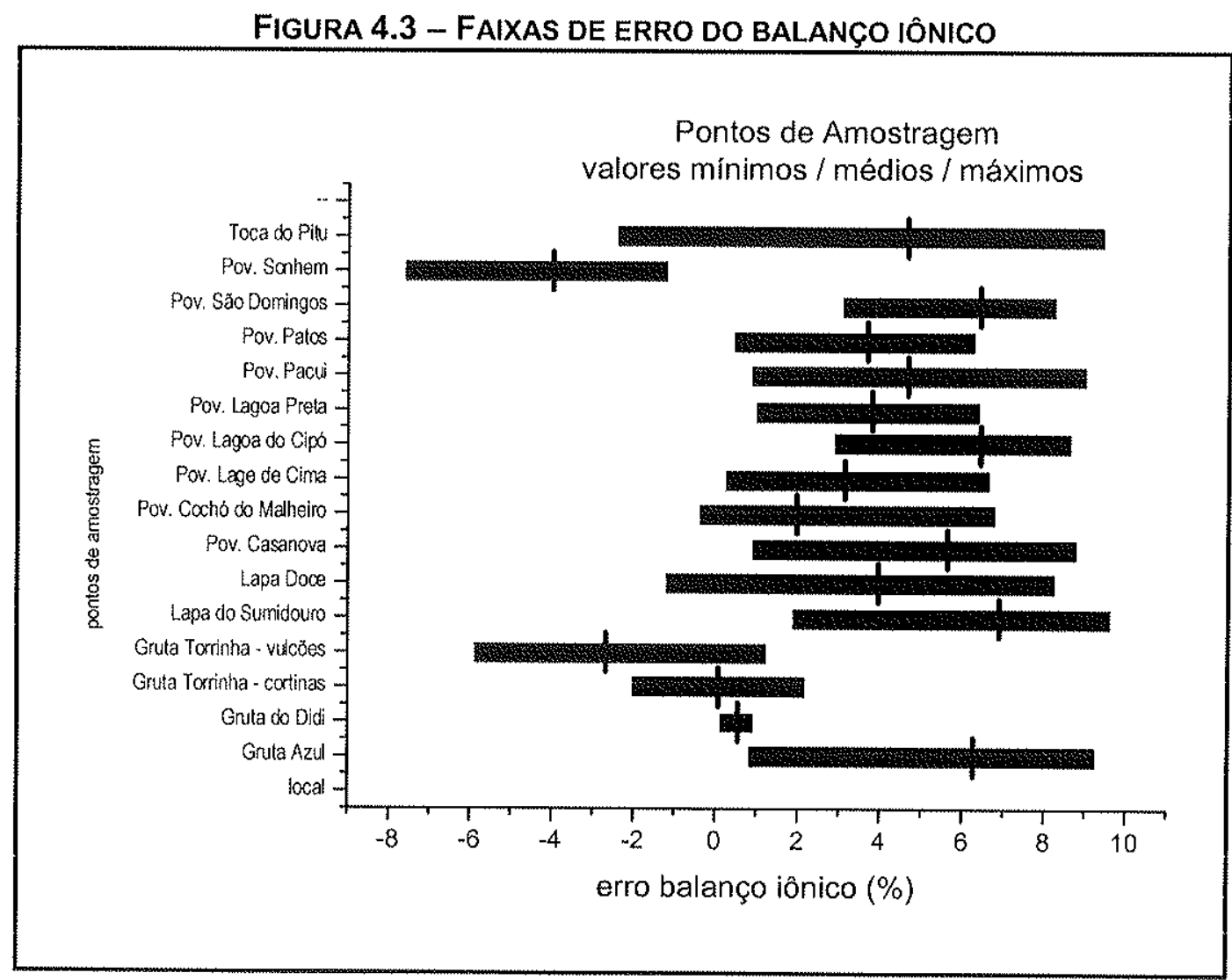

\subsection{6 - Fácies hidroquímicas}

A fácies hidroquímica representa um conjunto de parâmetros hidroquímicos e físico-químicos característicos desta que pode ser relacionado com ambientes de fluxo e origem da água (Back, 1960). A identificação destas fácies permite o entendimento da dinâmica hidroquímica do sistema.

Para o ponto de partida da amostragem da área de estudo, foram consideradas as fácies hidroquímicas típicas do modelo conceitual de sistemas cársticos carbonáticos (Drake \& Harmon, 1973). Para testar quantitativamente as diferenças e semelhanças hidroquímicas dos vários ambientes de fluxo, foi utilizado o método estatístico de análise de agrupamento (análise de cluster), com o objetivo de identificar semelhanças de parâmetros químicos de fácies inicialmente consideradas distintas devido à sua posição no modelo conceitual de fluxo de água no sistema cárstico. $O$ método estatístico confirma a distinção conceitual dos ambientes de fluxo, mas separa 
águas de mesmo ambiente ou até agrupa águas de ambientes diferentes com características químicas semelhantes, que nem sempre permite uma melhor interpretação dos resultados.

\section{Fácies 1 - escoamento superficial alogênico}

Esta fácies corresponde à água diretamente captada pela superfície dos metarenitos do Grupo Chapada alimentando parte da recarga alogênica do aqüífero cárstico. Na região são escassas drenagens perenes em virtude do baixo índice pluviométrico anual, desta forma, o ponto de coleta escolhido corresponde à nascente do riacho Água de Rega que recarrega o sistema o ano inteiro.

Quimicamente esta água é caracterizada pelo baixo $\mathrm{pH}(\overline{\mathrm{X}}=4,79 ; \mathrm{CV}=3,15 \%) \mathrm{e}$ de baixas concentrações dos principais cátions e ânions, onde destacam-se $\mathrm{SO}_{4}{ }^{2 *}$ $(\bar{x}=0,57 \mathrm{mg} / \mathrm{L} ; \mathrm{CV}=10,32 \%)$ e $\mathrm{HCO}_{3}{ }^{-}(\overline{\mathrm{x}}=2,90 \mathrm{mg} / \mathrm{L} ; \mathrm{CV}=89,94 \%)($ tabela 4.1$)$.

\section{Fácies 2 - Fluxo freático profundo não carbonático}

Esta fácies foi amostrada em poço perfurado pela CERB com entradas de água e filtros posicionados nos metarenitos do Grupo Chapada Diamantina. O poço escolhido situa-se no município de Seabra, povoado Cochó do Malheiro e tem 74 metros de profundidade. Uma característica que chama atenção é o forte odor de enxofre no momento de saída da água. Quimicamente, o teor de sulfato é baixo, o que significa que a espécie de enxofre encontrada está sob outra forma, provavelmente como HS. Ressalta-se uma concentração alta de $\mathrm{HCO}_{3}{ }^{-}(\overline{\mathrm{x}}=79,32 \mathrm{mg} / \mathrm{L})$ considerando que estas águas percolam metarenitos (tabela 4.1). Atribuj-se este fato a uma influência neste poço de águas provenientes de rochas carbonáticas, pois localiza-se nas proximidades do contato litológico entre os metarenitos sotopostos aos calcários. Esta fácies, juntamente com a água meteórica e o escoamento superficial alogênico, representam a recarga do sistema cárstico estudado.

\section{Fácies 3 - fluxo freático profundo carbonático}

Esta fácies é caracterizada pela circulação profunda da água no aqüífero cárstico. Do ponto de vista químico, estas águas representam a maior concentração de $\mathrm{HCO}_{3}{ }^{\prime \prime}$ de todo conjunto amostrado, com média igual a 359,08 mg/L. Na média as águas encontram-se saturadas para calcita $\left(S I_{c}=0,02\right)$ e insaturadas para gipsita $\left(\mathrm{SI}_{\mathrm{g}}\right.$ 
$=-1,51)$ e dolomita $\left(\left.S\right|_{d}=-0,08\right)$. Também ressalta-se a expressiva concentração para $\mathrm{Ca}^{2+} \quad(\bar{x}=175,51 ; C V=46,37 \%)$ quando comparada com a fácies 6 (ressurgências cársticas; $\bar{x}=67,70 ; C V=7,69 \%)$. A concentração de $\mathrm{SO}_{4}{ }^{2-}$ também é alta ( $\bar{x}=204,50$ $\mathrm{mg} / \mathrm{L} ; \mathrm{CV}=135,00 \%$ ), quando comparada com estudos realizadas em outras áreas cársticas. Karmann (1994), em estudo hidroquímico realizado na região cárstica do Vale do Ribeira, mostra valores máximos de $8 \mathrm{mg} / \mathrm{L}$ de $\mathrm{SO}_{4}{ }^{2-}$. No fácies de fluxo freático profundo carbonático, destaca-se um ponto de amostragem, poço do Povoado de Lagoa Preta, que exibe elevado valor médio para $\mathrm{SO}_{4}{ }^{2-} \quad(\bar{x}=746,07 \mathrm{mg} / \mathrm{L} ; \mathrm{CV}=$ $13,79 \%)$ quase o dobro em relação a média da concentração de $\mathrm{HCO}_{3}{ }^{-}(\bar{x}=388,09 ; \mathrm{CV}$ $=10,10 \%$ ) desta fácies (tabela 4.1).

\section{Fácies 4 - percolação autogênica vadosa}

Esta fácies é representada pela água de gotejamento de espeleotemas, cujos fluxos são alimentados através do sistema de fissuras e fraturas na rocha. A região de estudo, sobretudo na porção sul, tem inúmeras cavernas, porém, o número de espeleotemas ativos é pequeno, fato explicado pela escassez pluviométrica anual. Por outro lado, estas cavidades exibem uma riqueza em espeleotemas que nos permite afirmar que $o$ aporte de água em um passado geológico recente foi grande na região. $A$ espessura de rocha entre a superfície e o teto das cavidades varia entre 30 e 200 metros. Do ponto de vista hidroquímico as águas desta fácies são sui generis em relação às outras fácies, em função da distribuição das concentrações dos principais cátions e ânions (tabela 4.1). A concentração de cloreto tem valor máximo em 4460,80 $\mathrm{mg} / \mathrm{L}$, com média igual a $2240,31 \mathrm{mg} / \mathrm{L}$. A concentração de $\mathrm{SO}_{4}{ }^{2-}$ também é expressiva, com média igual a $305,09 \mathrm{mg} / \mathrm{L}$, superior em 3 vezes a concentração de $\mathrm{HCO}_{3}{ }^{-}$ $(\bar{x}=99,56 \mathrm{mg} / \mathrm{L})$.

\section{Fácies 5 - Reservatórios subterrâneos}

A fácies 5 corresponde a afloramentos do nivel d'água acessíveis em lagos subterrâneos encontrados em cavernas. Quimicamente é caracterizada pela alta concentração de $\mathrm{HCO}_{3}{ }^{-}(\bar{x}=305,10 \mathrm{mg} / \mathrm{L}$; tabela 4.1), e Indice de Saturação para calcita praticamente no equilibrio $\left(\mathrm{SI}_{\mathrm{c}}=-0,02\right)$. Destaca-se também a concentração média para $\mathrm{SO}_{4}{ }^{2-}(\overline{\mathrm{x}}=17,79 \mathrm{mg} / \mathrm{L} ; \mathrm{CV}=52,03 \%)$, pequena quando comparada a outras fácies do sistema, porém expressiva em relação a este tipo de ambiente. 


\section{Fácies 6 - Nascentes cársticas}

As nascentes cársticas representam uma mistura das fácies, pois tendem a representar o escoamento de águas coletadas e transmitidas pelo sistema cárstico e sua bacia de captação. Quimicamente, a água desta fácies, tem alto teor de $\mathrm{HCO}_{3}{ }^{-}$ $(\bar{x}=246,96 \mathrm{mg} / \mathrm{L} ; C V=11,0 \%)$ e $\mathrm{SI}_{\mathrm{c}}=0,00(0,28$ a $-0,37)$, em equilíbrio de saturação para o mineral calcita. A concentração de $\mathrm{SO}_{4}{ }^{2-}(\bar{X}=19,30 \mathrm{mg} / \mathrm{L} ; \mathrm{CV}=31,47 \%)$, apesar de ser menor em relação às outras fácies, é significativa por se tratar de um exutório do sistema (tabela 4.1).

\section{Fácies 7 - Água meteórica}

Esta fácies representa uma das principais recargas hidricas, juntamente com a fácies de percolação freática profunda não carbonática. É analisada para quantificar a entrada externa de íons ao sistema. Quimicamente são caracterizadas por baixas concentrações dos principais cátions e ânions (tabela 4.3), com médias inferiores a 0,5 $\mathrm{mg} / \mathrm{L}$.

TABELA 4.3 - PARÂMETROS HDROQUÍMICOS DAS ÁGUAS DE CHUVAS NA BACIA DE IRECÊ

\begin{tabular}{ccccccccc}
\hline $\begin{array}{c}\text { parâmetro } \\
\text { amostra }\end{array}$ & $\begin{array}{c}\mathrm{Ca}^{2+} \\
(\mathrm{mg} / \mathrm{L})\end{array}$ & $\begin{array}{c}\mathrm{Mg}^{2+} \\
(\mathrm{mg} / \mathrm{L})\end{array}$ & $\begin{array}{c}\mathrm{Na}^{+} \\
(\mathrm{mg} / \mathrm{L})\end{array}$ & $\begin{array}{c}\mathrm{K}^{+} \\
(\mathrm{mg} / \mathrm{L})\end{array}$ & $\begin{array}{c}\mathrm{Cl}^{*} \\
(\mathrm{mg} / \mathrm{L})\end{array}$ & $\begin{array}{c}\mathrm{SO}_{4}{ }^{2-} \\
(\mathrm{mg} / \mathrm{L})\end{array}$ & $\begin{array}{c}\mathrm{HCO}_{3}{ }^{-} \\
(\mathrm{mg} / \mathrm{L})\end{array}$ & época \\
\hline BAch32 & 0.08 & nd & 0.10 & nd & 0.04 & 0.20 & 0 & set/03 \\
BAch33 & 0.18 & 0.02 & 0.10 & nd & 0.05 & 0.20 & 0 & out/03 \\
BAch80 & 1.81 & 0.17 & 0.23 & $<0,5$ & n.d. & 0.40 & 0 & jan/04 \\
BAch01 & 0.07 & $<0,1$ & $<0,1$ & $<0,5$ & n.d. & 0,10 & 0 & fev/04 \\
BAch02 & 0.07 & $<0,1$ & $<0,1$ & $<0,5$ & n.d. & 0,09 & 0 & fev/04 \\
BAch03 & 0.07 & $<0,1$ & $<0,1$ & $<0,5$ & n.d. & 0,09 & 0 & mar/04 \\
BAch04 & 0.07 & $<0,1$ & $<0,1$ & $<0,5$ & n.d. & 0,07 & 0 & mar/04 \\
\hline
\end{tabular}




\section{3 - Modelamento hidroquímico do sistema}

\subsection{1 - Introdução}

O acido carbônico, devido à disponibilidade global de $\mathrm{CO}_{2}$ na atmosfera e solo, é aceito como agente primordial na dissolução de rochas carbonáticas, sendo responsável pela grande maioria dos processos químicos associados à geração dos relevos cársticos (Ford \& Williams, 1989). A reação geral pode ser sintetizada como:

$$
\mathrm{CaCO}_{3}+\mathrm{H}_{2} \mathrm{O}+\mathrm{CO}_{2}=2 \mathrm{HCO}_{3}^{-}+\mathrm{Ca}^{2+} \text { (r. 4.1) }
$$

No entanto, alguns estudos de caso em determinadas partes do mundo têm demonstrado a importância espeleogenética da dissolução de rochas carbonáticas por ácido sulfúrico. Esta idéia foi introduzida por Morehouse(1968). Dois mecanismos distintos tem sido propostos para explicar a geração de ácido sulfúrico na água subterrânea:

\section{A - Oxidação de $\mathrm{H}_{2} \underline{\mathrm{S}}$}

A reação de hidrocarbonetos (gás natural) em ascensão, com $\mathrm{CaSO}_{4}$ presente em corpos rochosos, produz sulfeto de hidrogênio, água e dióxido de carbono (r. 4.2). $\mathrm{O}_{2} \mathrm{~S}$ e $\mathrm{CO}_{2}$ continuam em ascensão até se misturarem com o oxigênio da água subterrânea retida ao longo de sistemas de descontinuidades na rocha. A combinação de $\mathrm{H}_{2} \mathrm{~S}$ com oxigênio proporciona a geração de ácido sulfúrico (r. 4.3), por outro lado, o próprio $\mathrm{H}_{2} \mathrm{~S}$ pode sofrer dissociação gerando íons $\mathrm{H}^{+}$(r. 4.4) (Hill, 1987, 1995).

$$
\begin{gathered}
\left.\mathrm{C}_{\mathrm{n}} \mathrm{H}_{\mathrm{n}}+\mathrm{SO}_{4}{ }^{2 *} \leftrightarrow \mathrm{H}_{2} \mathrm{~S}+\mathrm{CO}_{2}+\mathrm{H}_{2} \mathrm{O} \quad \text { (r. } 4.2\right) \\
\left.\mathrm{H}_{2} \mathrm{~S}+2 \mathrm{O}_{2} \leftrightarrow \mathrm{H}_{2} \mathrm{SO}_{4} \quad \text { (r. } 4.3\right) \\
\left.\mathrm{H}_{2} \mathrm{~S} \leftrightarrow \mathrm{H}^{+}+\mathrm{HS}^{-} \quad \text { (r. } 4.4\right)
\end{gathered}
$$


O ácido sulfúrico assim gerado irá promover a dissolução da rocha carbonática (r. 4.5).

$$
\mathrm{H}_{2} \mathrm{SO}_{4}+\mathrm{CaCO}_{3}+2 \mathrm{H}_{2} \mathrm{O} \leftrightarrow \mathrm{CaSO}_{4} \cdot 2 \mathrm{H}_{2} \mathrm{O}+\mathrm{H}^{+}+\mathrm{HCO}_{3}^{-} \text {(r. 4.5) }
$$

\section{B - Oxidação de sulfetos (pirita $-\mathrm{FeS}_{2}$ )}

Os sulfetos metálicos, a exemplo da pirita, galena e esfarelita, podem ser encontrados disseminados nos calcários e desta forma sofrerem oxidação e formar ácido sulfúrico (r. 4.6). (Egemeier, 1981; Garrels \& Christ, 1965; Hill, 1965; Ford \& Williams, 1990)

$$
\begin{gathered}
\left.\mathrm{FeS}_{2}+3 \mathrm{O}_{2}+2 \mathrm{H}_{2} \mathrm{O}=\mathrm{Fe}^{+}+2 \mathrm{H}_{2} \mathrm{SO}_{4} \quad \text { (r. } 4.6\right) \\
\left.\mathrm{H}_{2} \mathrm{SO}_{4}+\mathrm{CaCO}_{3}=\mathrm{CaSO}_{4}+\mathrm{H}_{2} \mathrm{O}+\mathrm{CO}_{2} \quad \text { (r. } 4.7\right)
\end{gathered}
$$

Um dos produtos da equação (r. 4.7) é o $\mathrm{CO}_{2}$, que estará disponível para outras reações, incluindo principalmente a formação de $\mathrm{H}_{2} \mathrm{CO}_{3}$ que também dissolverá calcita e produzirá hidrogenocarbonato.

No balanço das massas para cada mol de pirita oxidada 2 moles de ácido sulfúrico são adicionados, dobrando o número de moles de $\mathrm{CO}_{2}$ e assim aumentando o poder de solvência da solução. Desta forma, $1 \mathrm{~mol}$ de pirita oxidada pode resultar na dissolução adicional de 6 moles de calcita (Ball \& Jones, 1990).

\subsection{2 - Estequiometria}

Considerando os principais agentes corrosivos e as reações envolvidas, apresenta-se a seguir a análise estequiométrica dos resultados analíticos obtidos para as diferentes fácies hidroquimicas da área de estudo.

A análise estequiométrica fundamenta-se no equilibrio molar e no balanço de massas entre as espécies envolvidas numa reação química e seus produtos (Stumm \& Morgan, 1995). As reações consideradas no presente estudo correspondem às reações clássicas de dissolução de rochas carbonáticas por ácido carbônico, reações de 
dissolução de rochas carbonáticas exclusivamente com ácido sulfúrico e também a reação de dissolução de rochas carbonáticas envolvendo ação simultânea destes dois ácidos. Assim, considerando que o processo de dissolução da rocha produz íons presentes em solução aquosa, estes deverão obedecer as razões estequiométricas das reações, caso o sistema seja operado por estas reações.

Partindo dessa premissa, para cada fácies, os resultados analíticos, expressos em $\mathrm{mmol} / \mathrm{L}$, foram testados com as reações possiveis de forma a determinar as reações químicas dominantes para cada ambiente. Para validar os resultados, os seguintes critérios foram adotados:

- margem de tolerância de $20 \%$, composta por $10 \%$ relativo à margem de erro admitido no cálculo do balanço iônico, $5 \%$ em virtude de não serem considerados no cálculo outros íons presentes e $5 \%$ de contingência;

- os cálculos das razões foram efetuados considerando os valores médios, máximos e mínimos do conjunto de amostras de cada fácies, dos ions envolvidos $\left(\mathrm{Ca}^{2+}, \mathrm{Mg}^{2+} . \mathrm{HCO}_{3}{ }^{-}, \mathrm{SO}_{4}{ }^{2-}\right)$ (tabela 4.1), sendo que nas razões molares com mais de um cátion o numerador constitui-se da soma dos cátions envolvidos, tal como a seguir:

razão média razão máxima razo mínima

\begin{tabular}{|c|c|c|c|}
\hline$\frac{\text { cátion }^{+}}{\text {ânion }}$ & cátion $_{\text {ânion" }}{ }_{\text {(med) }}$ & $\frac{\text { cátion }^{+}}{\text {ânion }}$ & $\frac{\text { cátion }^{+} \text {(min) }}{\text { ânion }}$ \\
\hline & & & ânion ${ }^{-}$(max) \\
\hline
\end{tabular}

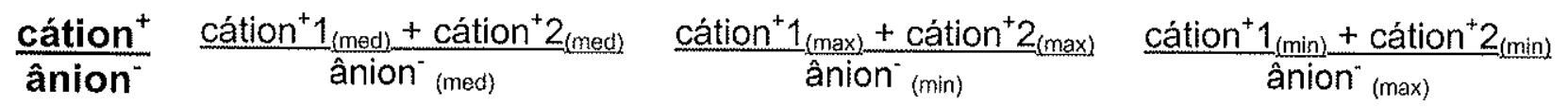

- Condições de aceitação: todos resultados dentro da margem percentual estabelecida - aceito; dois resultados, dentre os máximos, médios e mínimos, dentro da margem percentual estabelecida - parcial; um ou nenhum resultado, dentre os máximos, médios e mínimos, dentro da margem percentual - não aceito.

As tabelas 4.4 e 4.5 , a seguir, exibem as razões estequiométricas das reações químicas de dissolução de rochas carbonáticas por ácido carbônico em função das fácies hidroquímicas, bem como um diagnóstico de aceitação dos resultados. 
TABELA 4.4 - RAZÕES ESTEQUIOMÉTRICAS ENTRE AS FÁGIES HIDROQUIMICAS E A REAÇÃO DE DISSOLUÇÃO DE ROCHA CARBONÁTICA (CALCÁRIO) POR ÁCIDO CARBÔNICO

\begin{tabular}{|c|c|c|c|c|c|}
\hline $\mathrm{CaCO}_{3}$ & $+\mathrm{H}_{2} \mathrm{CO}_{3}=$ & $\mathrm{Ca}^{2+}$ & $+2 \mathrm{HCO}_{3}$ & $\frac{\mathrm{Ca}^{2+}}{2 \mathrm{HCO}_{3}^{-}}$ & $\begin{array}{c}\text { (r. } 4.1) \\
\text { faixa de } \\
\text { tolerância }\end{array}$ \\
\hline & Massa Molar & 40.08 & 122.03 & 0.33 & 0,26 a 0,39 \\
\hline fácies & med & $\max$ & $\min$ & & condição \\
\hline 1 & 0.44 & 34.25 & 0.16 & & não aceito \\
\hline 2 & 0.36 & 0.46 & 0.28 & . & parcial \\
\hline 3 & 0.73 & 2.20 & 0.23 & & não aceito \\
\hline 4 & 8.47 & 36.79 & 2.97 & & não aceito \\
\hline 5 & 0.45 & 1.07 & 0.24 & & não aceito \\
\hline 6 & 0.42 & 0.53 & 0.31 & & não aceito \\
\hline
\end{tabular}

TABELA 4.5 - RAZÕES ESTEQUIOMÉTRICAS ENTRE AS FÁCIES HIDROQUÍMICAS E A REAÇÃO DE DISSOLUÇÃO DE ROCHA CARBONÁTICA (DOLOMITO) POR ÁCIDO CARBÔNICO

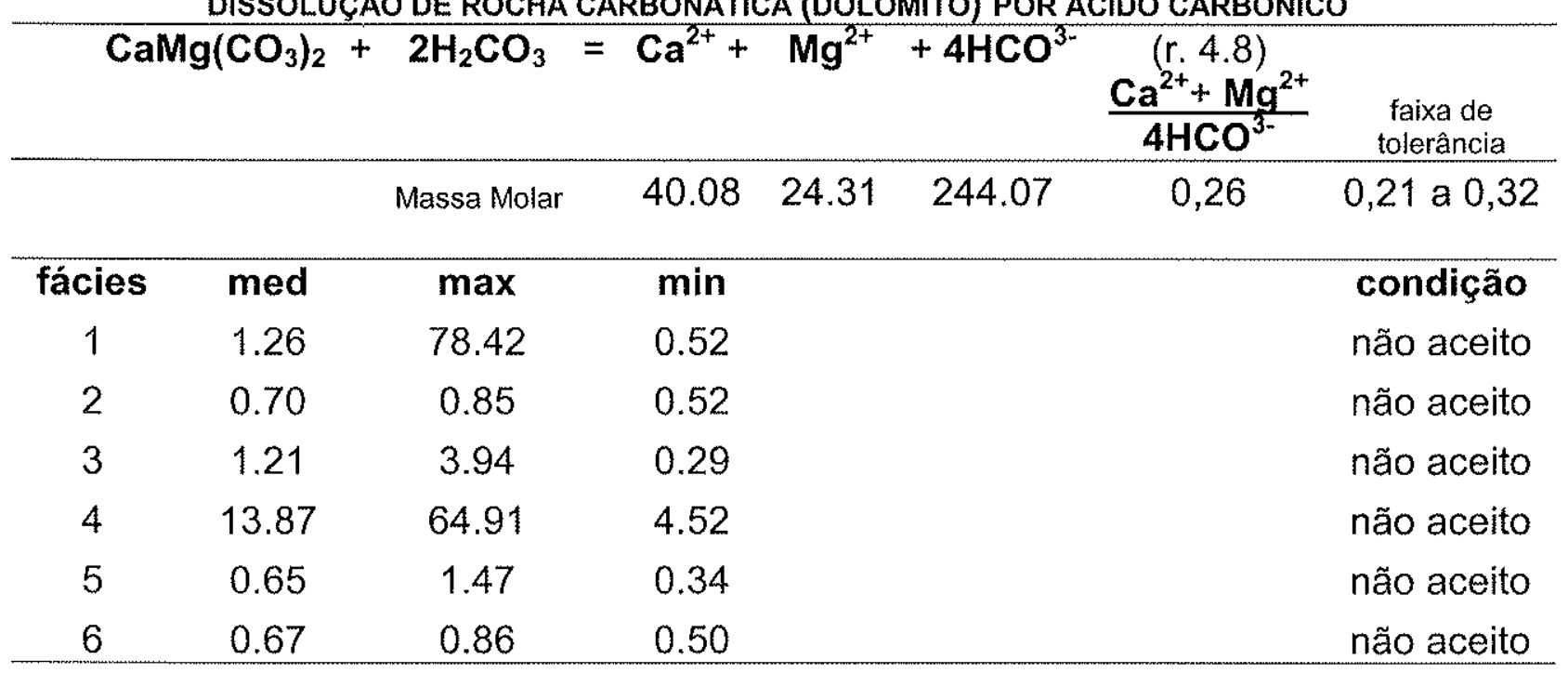

Tendo em vista os resultados dos cálculos das razões entre as massas das espécies envolvidas nas reações (r.4.1) e (r. 4.8) (tabelas 4.4 e 4.5), desenvolveu-se um outro raciocínio (quadros 4.1, 4.2 e 4.3), que considera a razão molar típica das reações de dissolução em rochas carbonáticas, tal como segue: 
QUADRO 4.1 - RAZÕES MOLARES NAS REAÇŌES DE DISSOLUÇÃO POR $\mathrm{H}_{2} \mathrm{CO}_{3}$

\begin{tabular}{|c|c|c|c|c|c|c|c|}
\hline & & & & & & $\frac{\mathrm{Ca}^{2+}+\mathrm{Mg}^{2+}}{\mathrm{HCO}_{3}-}$ & $\frac{\mathrm{Ca}^{2+}+\mathrm{Mg}^{2+}}{\mathrm{SO}_{4}^{2-}}$ \\
\hline $\mathrm{CaCO}_{3}$ & $+\mathrm{H}_{2} \mathrm{CO}_{3}$ & $=\mathrm{Ca}^{2+}$ & \multicolumn{2}{|l|}{$+2 \mathrm{HCO}_{3}^{-}$} & \multirow[t]{2}{*}{$(r .4 .1)$} & $(1+0) / 2$ & -- \\
\hline 1 & 1 & 1 & \multicolumn{2}{|l|}{2} & & 0,5 & $m$ \\
\hline $\mathrm{CaMg}\left(\mathrm{CO}_{3}\right)_{2}$ & $+2 \mathrm{H}_{2} \mathrm{CO}_{3}$ & $=\mathrm{Ca}^{2+}$ & $\mathrm{Mg}^{2+}$ & $+4 \mathrm{HCO}_{3}{ }^{\circ}$ & \multirow[t]{2}{*}{$(r .4 .8)$} & $(1+1) / 4$ & --- \\
\hline 1 & 2 & 1 & 1 & 4 & & 0,5 & $-m$ \\
\hline
\end{tabular}

QUADRO 4.2 - RAZÕES MOLARES NAS REAÇOEES DE DISSOLUÇÃO POR $\mathrm{H}_{2} \mathrm{SO}_{4}$

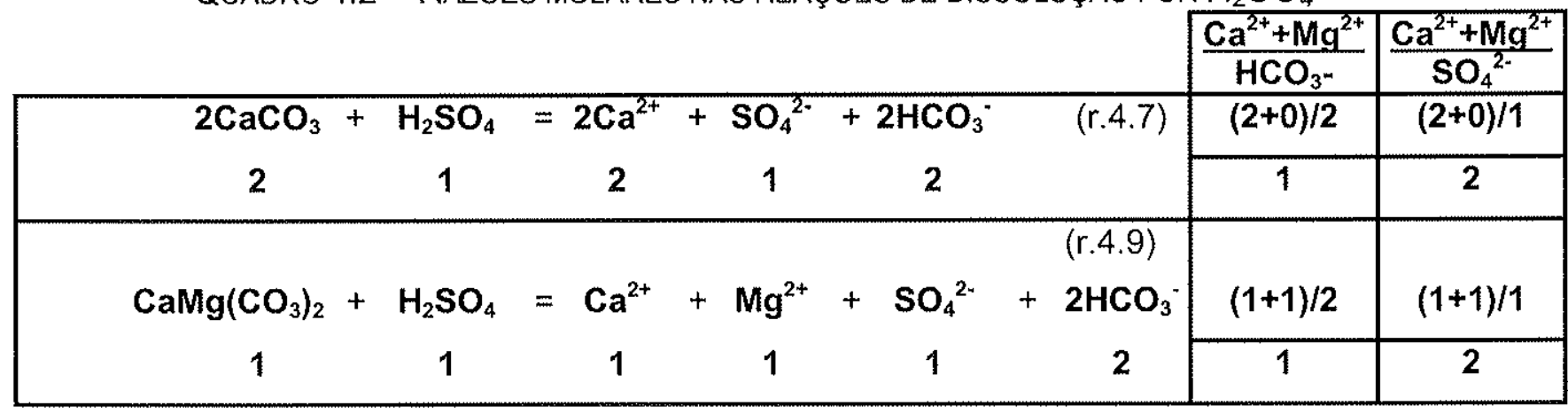

QUADRO 4.3 - RAZŌES MOLARES NAS REAÇOES DE DISSOLUÇÃO POR $\mathrm{H}_{2} \mathrm{SO}_{4} \mathrm{E} \mathrm{H}_{2} \mathrm{CO}_{3}$

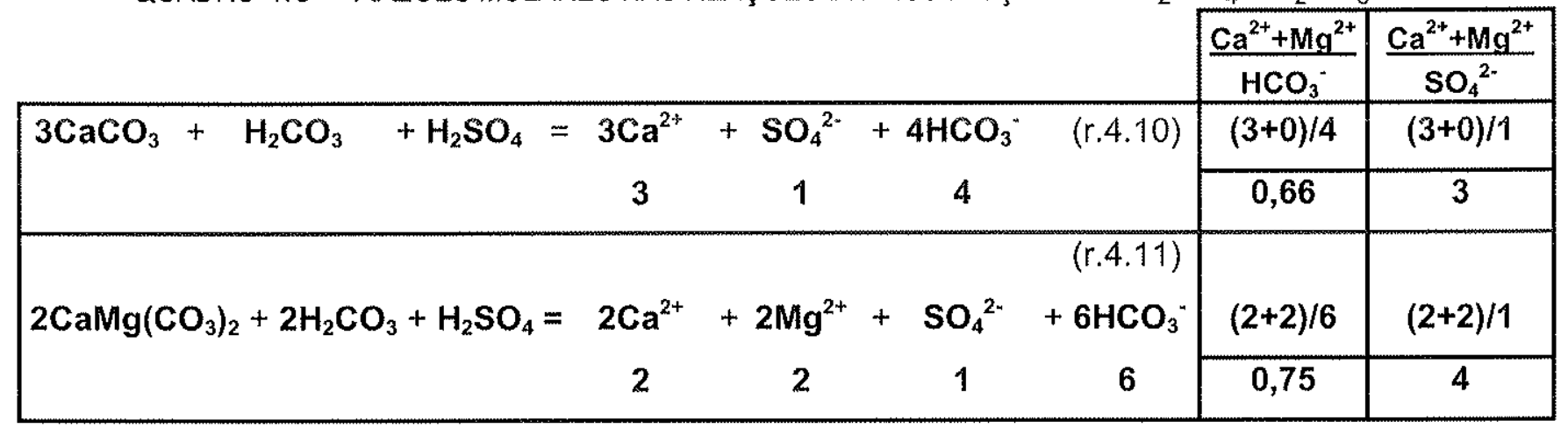

Nas reações relacionadas com a dissolução por ácido sulfúrico a relação molar entre $\mathrm{Ca}^{2+}+\mathrm{Mg}^{2+} / \mathrm{HCO}_{3}{ }^{-}$é igual a 1,0 (quadro 4.2). Esta mesma relação nas reações relacionadas à dissolução por ácido carbônico é igual a 0,5 (quadro 4.1). Observe-se que nas reações que envolvem a dissolução simultânea dos ácidos carbônico e sulfúrico, as relações molares entre $\mathrm{Ca}^{2+}+\mathrm{Mg}^{2+} / \mathrm{HCO}_{3}{ }^{n}$, referentes às reações (r. 4.10) (r. 4.11) são respectivamente 0,66 e 0,75. A relação entre os valores padrões para as razões molares, estabelecidos acima, com os dados hidroquímicos do carste estudado, permitem observar as tendências das reações químicas envolvidas (tabelas 4.6 e 4.7). Utilizou-se, para efeito de cálculo, os valores médios, adotando $20 \%$ de tolerância para aceitação, conforme estabelecido anteriormente. 
TABELA 4.6 - RAZÕES MOLARES ENTRE OS VALORES MÉdIOS DE $\mathrm{Ca}^{2+}+\mathrm{Mg}^{2+} / \mathrm{HCO}_{3}{ }^{-} \mathrm{NAS}$ FÁCIES HIDROQUÍMICAS

\begin{tabular}{|c|c|c|c|c|c|}
\hline fácies & $\begin{array}{c}\mathrm{Ca}^{2+} \\
\mathrm{mmol} / \mathrm{L}\end{array}$ & $\begin{array}{c}\mathrm{Mg}^{2+} \\
\mathrm{mmol} / \mathrm{L}\end{array}$ & $\begin{array}{c}\mathrm{HCO}_{3}{ }^{\prime \prime} \\
\mathrm{mmol} / \mathrm{L}\end{array}$ & $\frac{\mathrm{Ca}^{2+}+\mathrm{Mg}^{2+}}{\mathrm{HCO}_{3-}}$ & condição \\
\hline 1 & 0.02 & 0.04 & 0.05 & 1.25 & -- \\
\hline 2 & 0.46 & 0.44 & 1.30 & 0.69 & $(r .4 .10)$ \\
\hline 3 & 4.38 & 2.83 & 5.89 & 1.22 & $\sim(r .4 .7)(r .4 .9)$ \\
\hline 4 & 13.79 & 8.70 & 1.63 & 13.78 & - \\
\hline 5 & 2.25 & 0.98 & 5.00 & 0.65 & $($ r. 4.10$)$ \\
\hline 6 & 1.69 & 1.02 & 4.05 & 0.67 & $(\mathrm{r} .4 .10)$ \\
\hline
\end{tabular}

TABELA 4.7 - RAZÕES MOLARES ENTRE OS VALORES MÉdIOS DE $\mathrm{Ca}^{2+}+\mathrm{Mg}^{2+} / \mathrm{SO}_{4}{ }^{2-}$ NAS FÁCIES

\begin{tabular}{|c|c|c|c|c|c|}
\hline fácies & $\begin{array}{c}\mathrm{Ca}^{2+} \\
\mathrm{mmol} / \mathrm{L}\end{array}$ & $\begin{array}{c}\mathrm{Mg}^{2+} \\
\mathrm{mmol} / \mathrm{L}\end{array}$ & $\begin{array}{c}\mathrm{SO}_{4}^{2 *} \\
\mathrm{mmol} / \mathrm{L}\end{array}$ & $\frac{\mathrm{Ca}^{2+}+\mathrm{Mg}^{2+}}{\mathrm{SO}_{4}{ }^{2-}}$ & condição \\
\hline 1 & 0.02 & 0.04 & 0.006 & 10.00 & $\cdots$ \\
\hline 2 & 0.46 & 0.44 & 0.025 & 36.00 & $\ldots$ \\
\hline 3 & 4.38 & 2.83 & 2.129 & 3.38 & $(r .4 .10)(r .4 .11)$ \\
\hline 4 & 13.79 & 8.70 & 3.176 & 7.08 & -- \\
\hline 5 & 2.25 & 0.98 & 0.185 & 17.45 & --- \\
\hline 6 & 1.69 & 1.02 & 0.201 & 13.48 & --- \\
\hline
\end{tabular}

As condições estabelecidas nas tabelas 4.6 e 4.7 indicam que as fácies do carste estudado não estão controladas exclusivamente pelo sistema $\mathrm{CaCO}_{3}-\mathrm{H}_{2} \mathrm{CO}_{3}$. A fácies 1, por se tratar do escoamento alogênico, cujas concentrações dos sais são baixas, não enquadra-se em nenhuma equação de dissolução. A fácies 4 , percolação vadosa autogênica, é predisposta à deposição, fato evidenciado pelo alto valor na razão expressa na tabela 4.6. As demais fácies atestam a participação de ácido sulfúrico em conjunto com ácido carbônico, com destaque para a fácies 3 , fluxo freático profundo carbonático, cujo valor de razão molar indica que a participação do ácido sulfúrico como agente corrosivo é dominante. 


\section{4 - Evolução geoquímica do sistema estudado}

O sistema cárstico estudado é do tipo misto, ou seja, possui recarga meteórica autogênica, injeção de escoamento superficial alogênico e de fluxo freático alogênico. O impacto desta recarga sobre as rochas carbonáticas é quantificado através da diferença entre o Índice de Saturação (SI) das fácies de recarga e as fácies de circulação no carste (figuras 4.4, 4.5 e 4,6).

As águas das fácies 1 e 2 mostram-se insaturadas para calcita, dolomita e gipsita, com valores muito negativos, pelo fato de tratar-se de águas de escoamento alogênico e fluxo freático profundo não carbonático. Contudo, ressalta-se uma evolução crescente entre essas fácies, relacionada à circulação da água e a conseqüente mistura na fácies 2 .

Os gráficos das figuras 4.4, 4.5 e 4,6 seguem as tendências de um aqüifero cárstico típico (Ford \& Williams, 1989), onde as águas mais saturadas correspondem à percolação vadosa em fissuras e que as águas relacionadas à percolação em condutos profundos carbonáticos (fácies 3 ) atingem a saturação em relação à calcita e dolomita, mas continuam insaturadas em relação à gipsita, apesar da alta concentração de sulfato nas águas. $O$ gráfico da figura 4.7 , analisando apenas sua curva, mostra que existe uma proporção direta entre as concentrações de $\mathrm{SO}_{4}{ }^{2-}$ e $\mathrm{Ca}^{2+}\left(R^{2}=0,93\right)$ considerando que ocorre dissolução de $\mathrm{CaSO}_{4}$. Porém, considerando que as características geológicas dominantes no sistema cárstico estudado não dispõe de uma fonte primária de $\mathrm{CaSO}_{4}$ (Misi, 1979), a concentração de $\mathrm{Ca}^{2+}$ deve ser atribuída à dissolução de $\mathrm{CaCO}_{3}$. Desta forma, conclui-se que há uma fonte de $\mathrm{SO}_{4}{ }^{2-}$, externa ao sistema $\mathrm{CaCO}_{3}-\mathrm{CaSO}_{4}-\mathrm{H}_{2} \mathrm{O}$, relacionada com a dissolução de ácido sulfúrico na rocha carbonática. 
FIgURA 4.4 - ÍNDICE DE SATURAÇÃo EM GIPSITA X FÁCIES HIDROQUÍMICAS

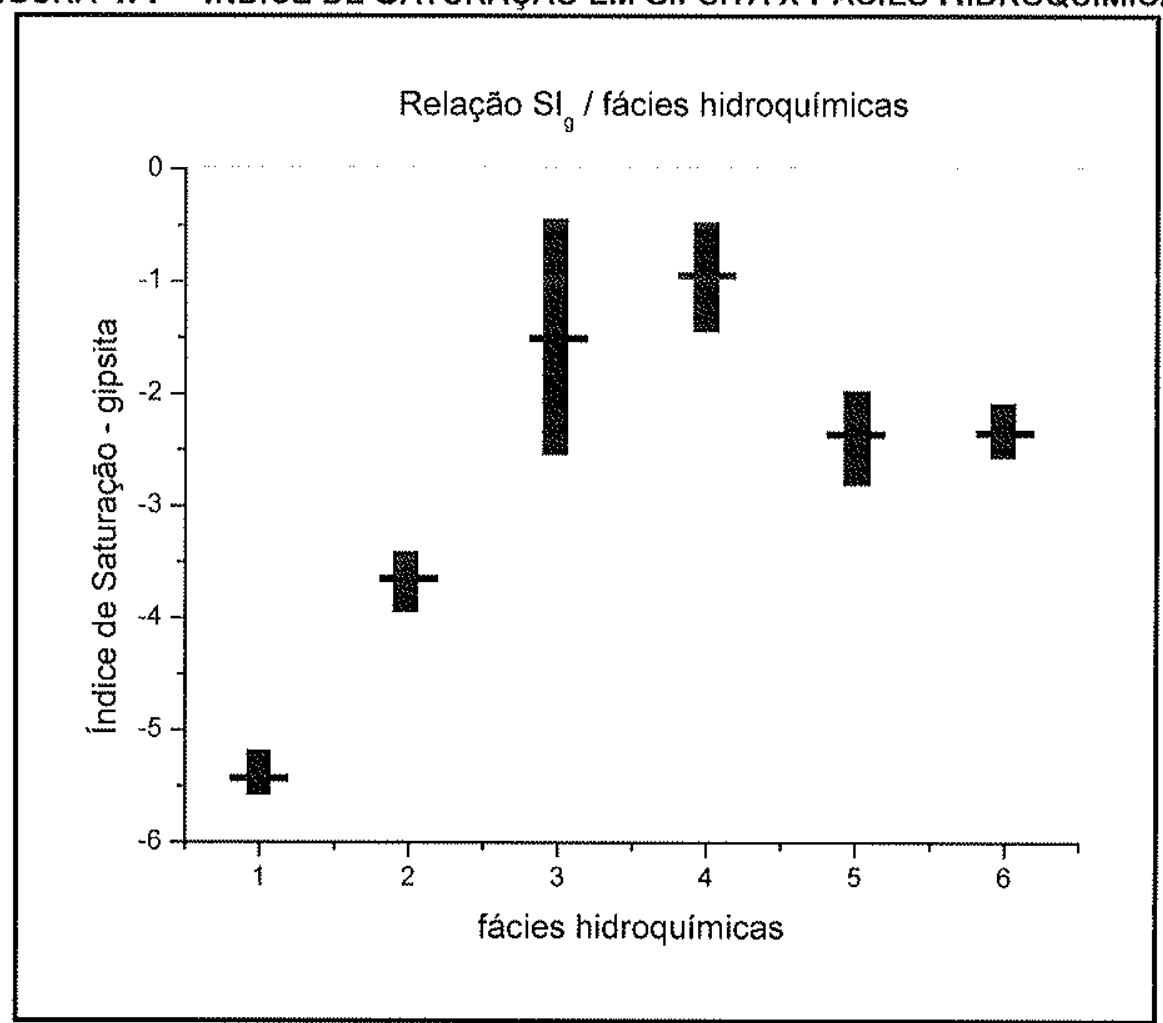

fácies 1 - escoamento alogênico; fácies 2 - fluxo freático profundo não carbonático; fácies 3 - fluxo freático profundo carbonático; fácies 4 - percolação vadosa autogênica; fácies 5 - reservatórios subterrâneos; fácies 6 - nascentes cársticas

FIGURA 4.5 - ÍNDICE DE SATURAÇÃO EM DOLOMITA X FÁCIES HIDROQUÍMICAS

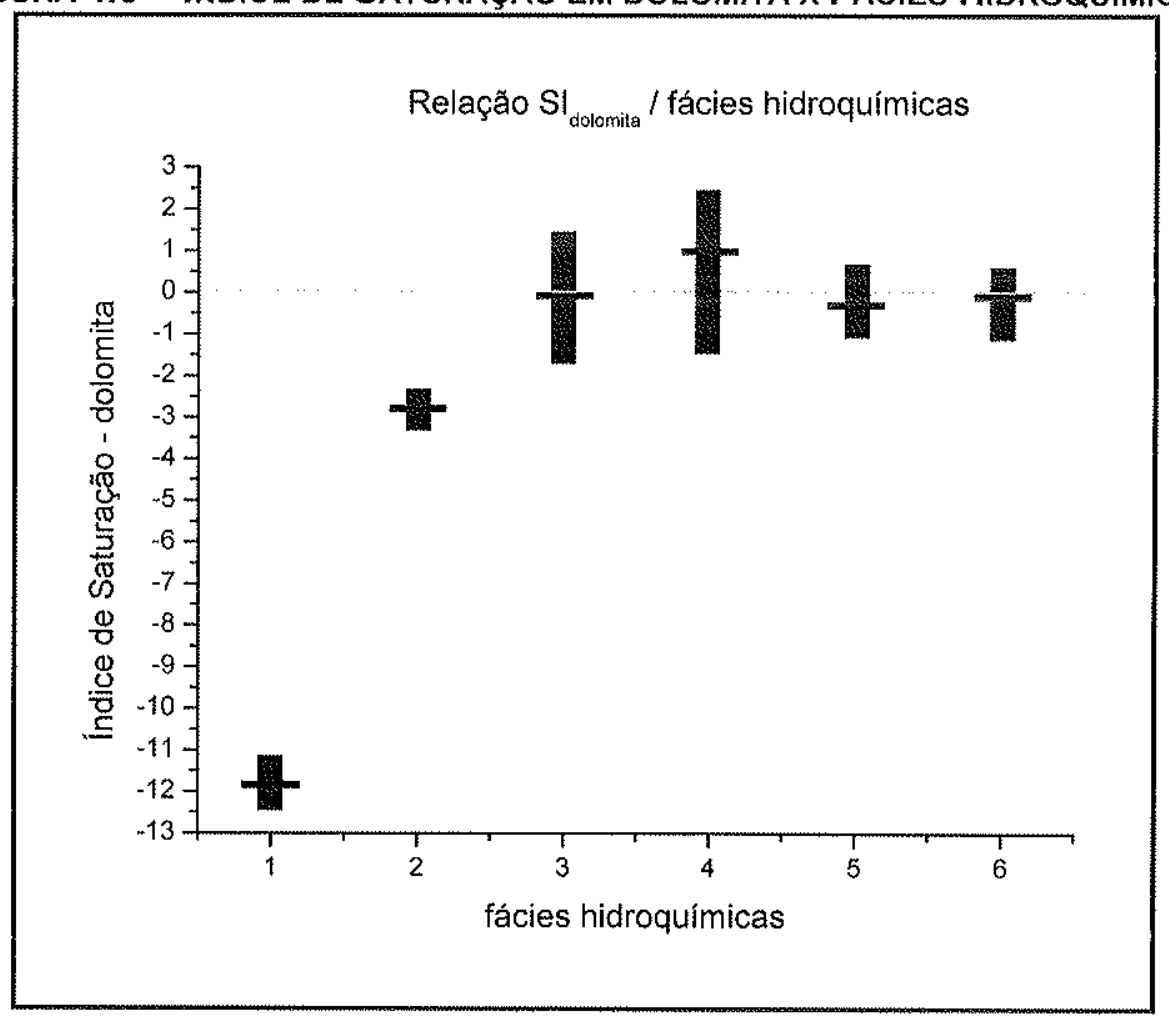


FiguRA 4.6 - ÍNDICE de SATURAÇÃo EM CALCITA X FÁCIES HIDROQUímicas

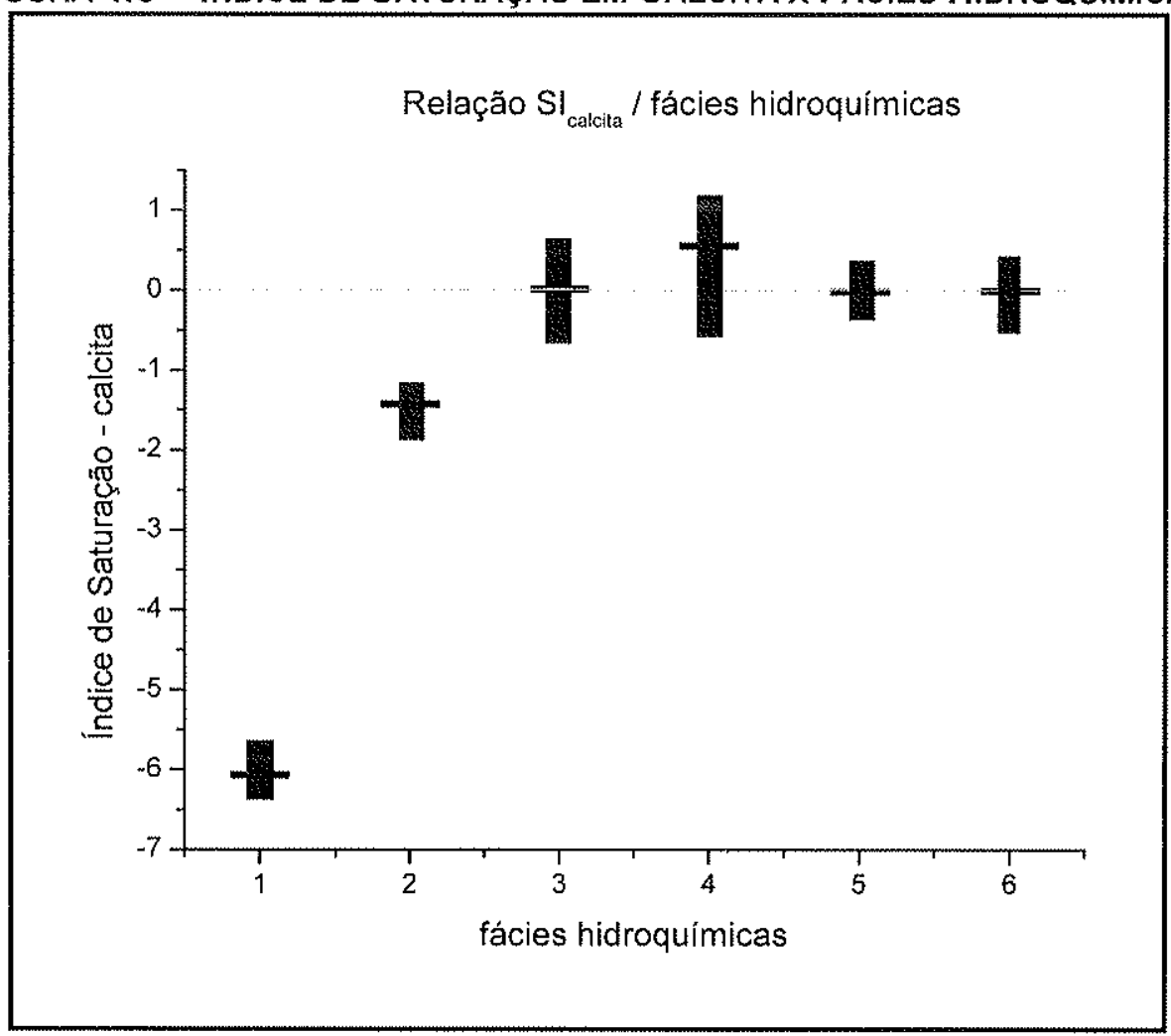

fácies 1 - escoamento alogênico; fácies 2 - fluxo freático profundo não carbonático; fácies 3 - fuxo freático profundo carbonático; fácies 4 m percolação vadosa autogênica; fácies 5 - reservatórios subterrâneos; fácies 6 - nascentes cársticas

FIGURA 4.7 - RELAÇÃO $\mathrm{SI}_{\text {GIPSITA }} \times \mathrm{SO}_{4}{ }^{2-}$

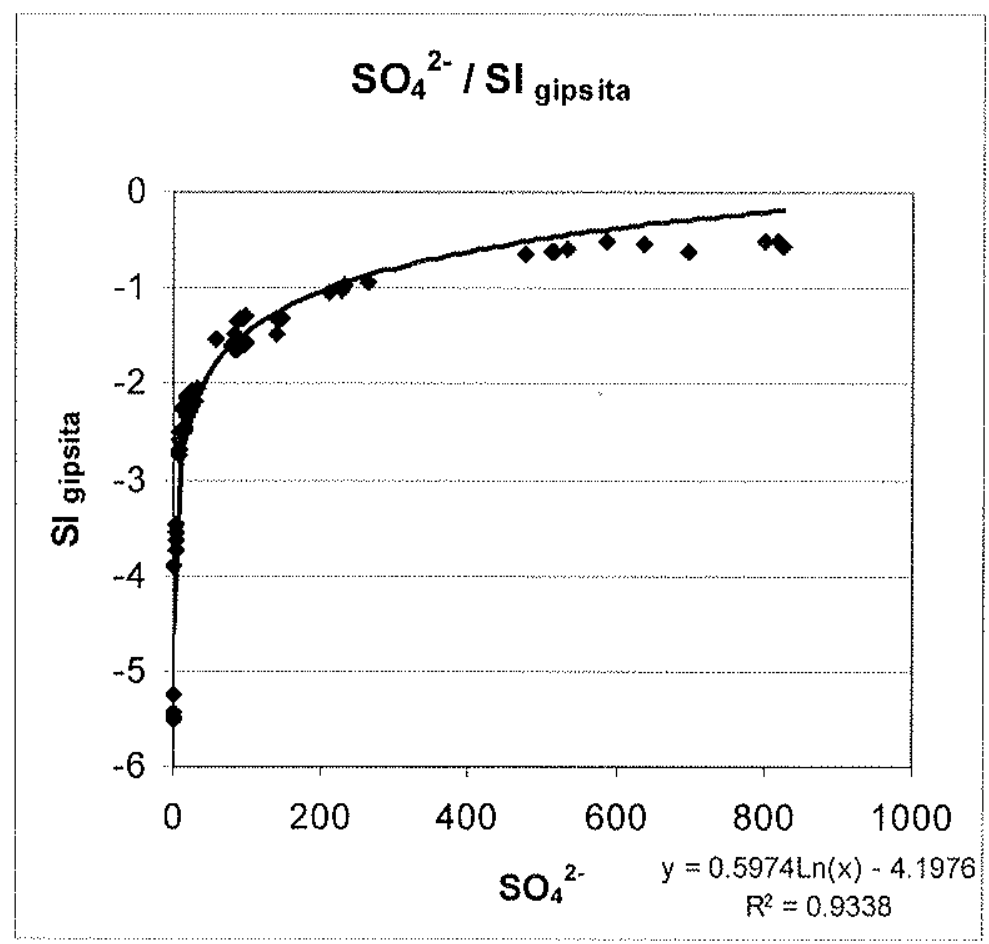


A figura 4.8 demonstra a variação de $\mathrm{pCO}_{2}$ em função do $\mathrm{SI}_{\text {calcita }}$ das fácies hidroquímicas. Analisando o gráfico pode-se observar que entre os parâmetros há uma relação inversamente proporcional entre $\mathrm{SI}_{\text {calcita }}$ e $\mathrm{pCO}_{2}$. A relação entre $\mathrm{SI}_{\text {calcita }}$ e $\mathrm{pCO}_{2}$ segue o padrão de águas cársticas, mas o que ressalta é o fato de que as águas mais profundas e com tempo de residência maior, alinham-se numa trajetória que parte de águas com $\mathrm{pCO}_{2}$ maior que as demais fácies hidroquímicas, isto é, no ambiente mais profundo há produção de $\mathrm{CO}_{2}$. Este fato difere, por exemplo, do sistema cárstico identificado no vale do Ribeira cuja $\mathrm{pCO}_{2}$ é mais expressiva na zona epicárstica (Karmann, 1994). Portanto, no carste estudado, deve haver uma fonte de $\mathrm{CO}_{2}$ para a fácies freática profunda, além do $\mathrm{CO}_{2}$ atmosférico e do solo, que pode ser atribuída à oxidação de pirita, conforme as reações abaixo:

$$
\begin{array}{cc}
\mathrm{FeS}_{2}+3 \mathrm{O}_{2}+2 \mathrm{H}_{2} \mathrm{O}=\mathrm{Fe}^{+}+2 \mathrm{H}_{2} \mathrm{SO}_{4} & (\mathrm{r} .4 .6) \\
\mathrm{H}_{2} \mathrm{SO}_{4}+\mathrm{CaCO}_{3}=\mathrm{CaSO}_{4}+\mathrm{H}_{2} \mathrm{O}+\mathrm{CO}_{2} & (\text { r. } 4.7)
\end{array}
$$

FIGURA 4.8 - RELAÇÕES $\mathrm{SI}_{\text {CALCITA }} \times \mathrm{PCO}_{2}$

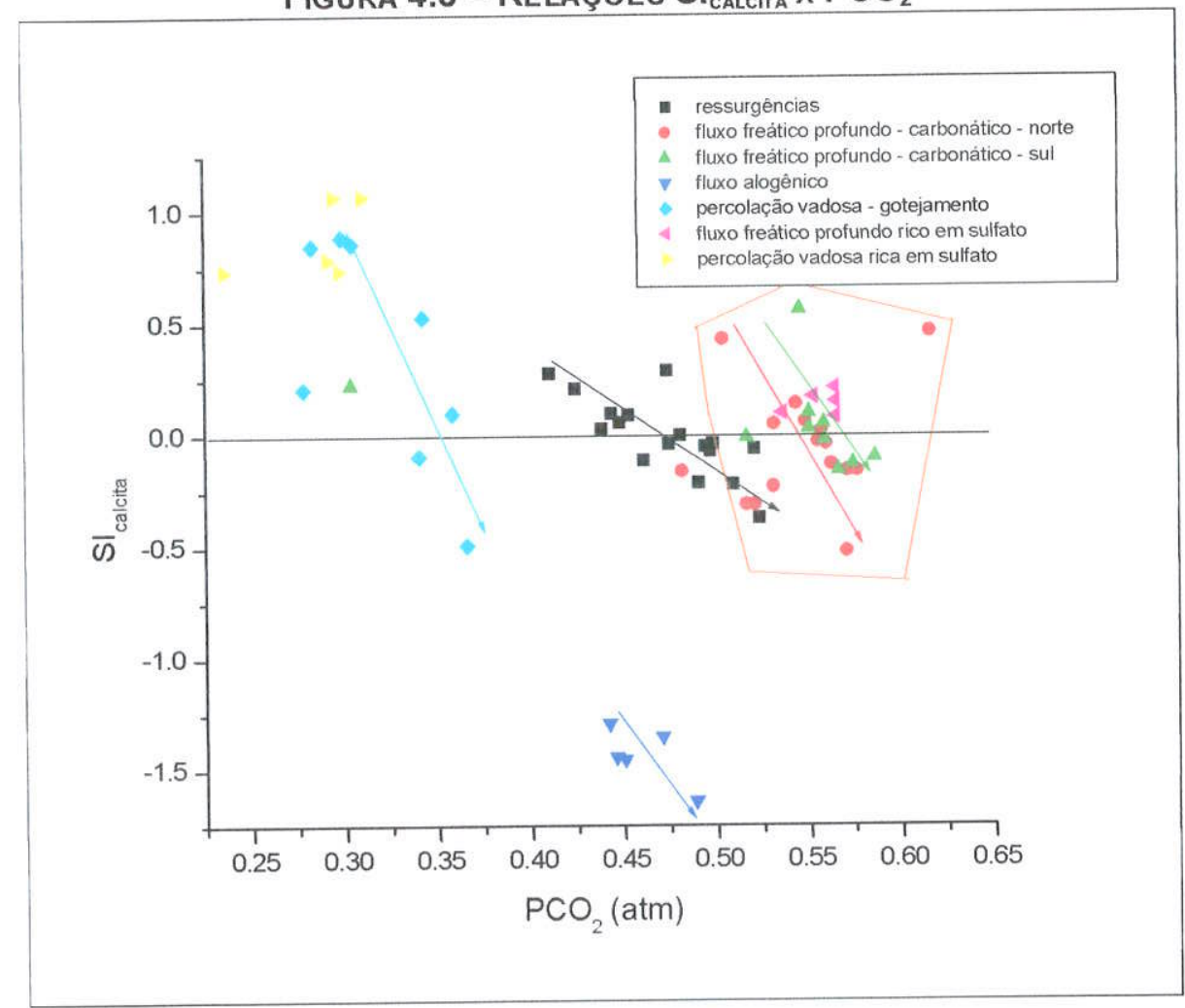


Observando-se a relação entre $\mathrm{Ca}^{2+}+\mathrm{Mg}^{2+} / \mathrm{SO}_{4}{ }^{2-}$ (figura 4.9), nota-se ótima correlação $\left(\mathrm{R}^{2}=0,9323\right)$, em contraposição à relação $\mathrm{Ca}^{2+}+\mathrm{Mg}^{2+} / \mathrm{HCO}_{3}{ }^{\prime \prime}$ (figura 4.10) com baixa correlação $\left(R^{2}=0,15\right)$. Se a corrosão das rochas carbonáticas do sistema estudado fosse exclusivamente controlada pelo ácido carbônico, a relação $\mathrm{Ca}^{2+}+\mathrm{Mg}^{2+}$ $/ \mathrm{HCO}_{3}{ }^{-}$deveria ter boa correlação, independente da relação entre $\mathrm{Ca}^{2+}+\mathrm{Mg}^{2+} / \mathrm{SO}_{4}{ }^{2-}$. Por outro lado, as correlações observadas, considerando a inexistência de fontes primárias de sulfato na rocha (Misi, 1979) no ambiente de circulação profunda, indicam que a corrosão de rocha carbonática por ácido carbônico não é dominante e que deve ter um processo gerador de sulfato. Portanto, atribui-se a origem do sulfato à reação entre o a rocha carbonática e ácido sulfúrico, sendo este proveniente da oxidação de pirita, com catálise microbiana (capítulo 8). As reações (r. 4.6),(r. 4.7), (r. 4.9) e (r. 4.10) indicam esta condição.

FIGURA 4.9 - RELAÇÃO $\mathrm{Ca}^{2+}+\mathrm{Mg}^{2+} / \mathrm{SO}_{4}^{2-}$

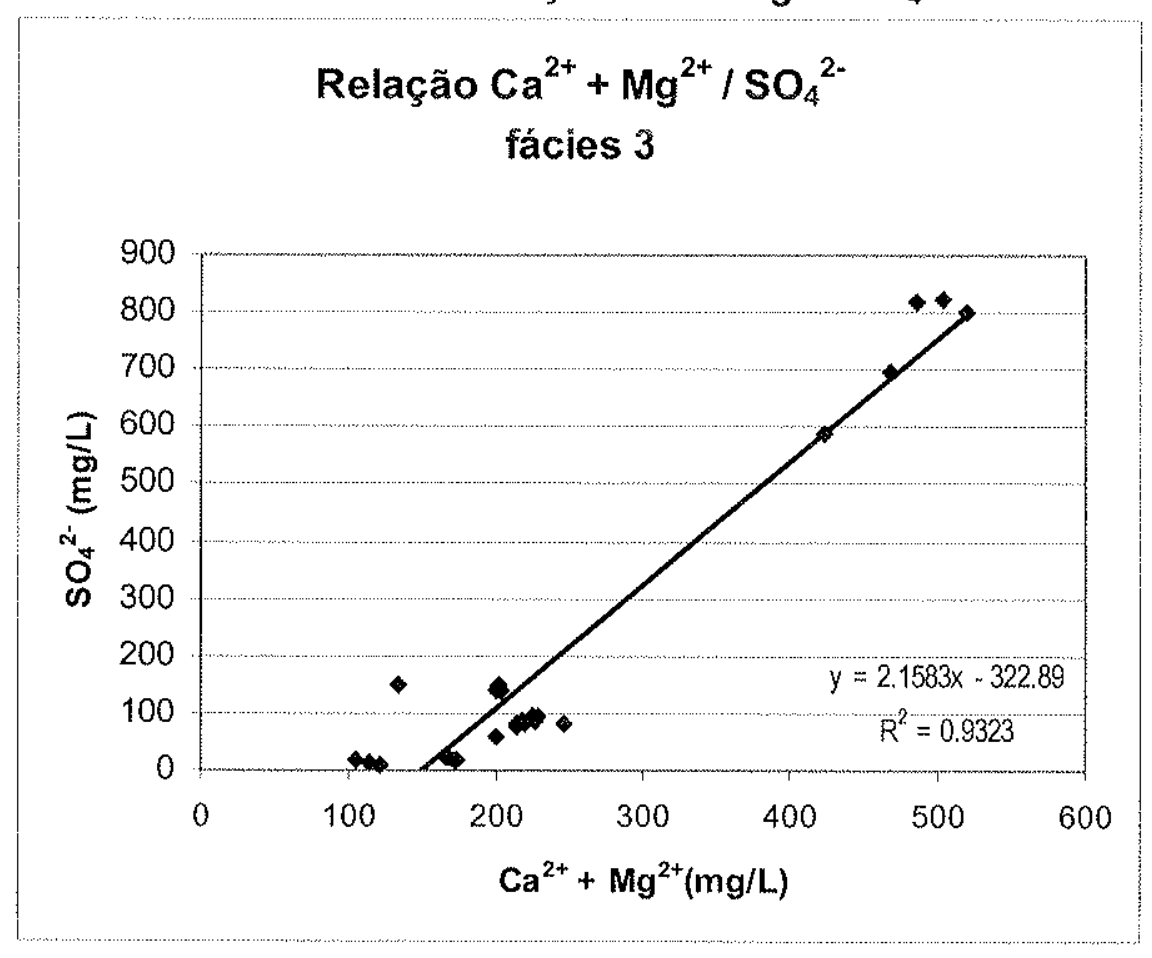




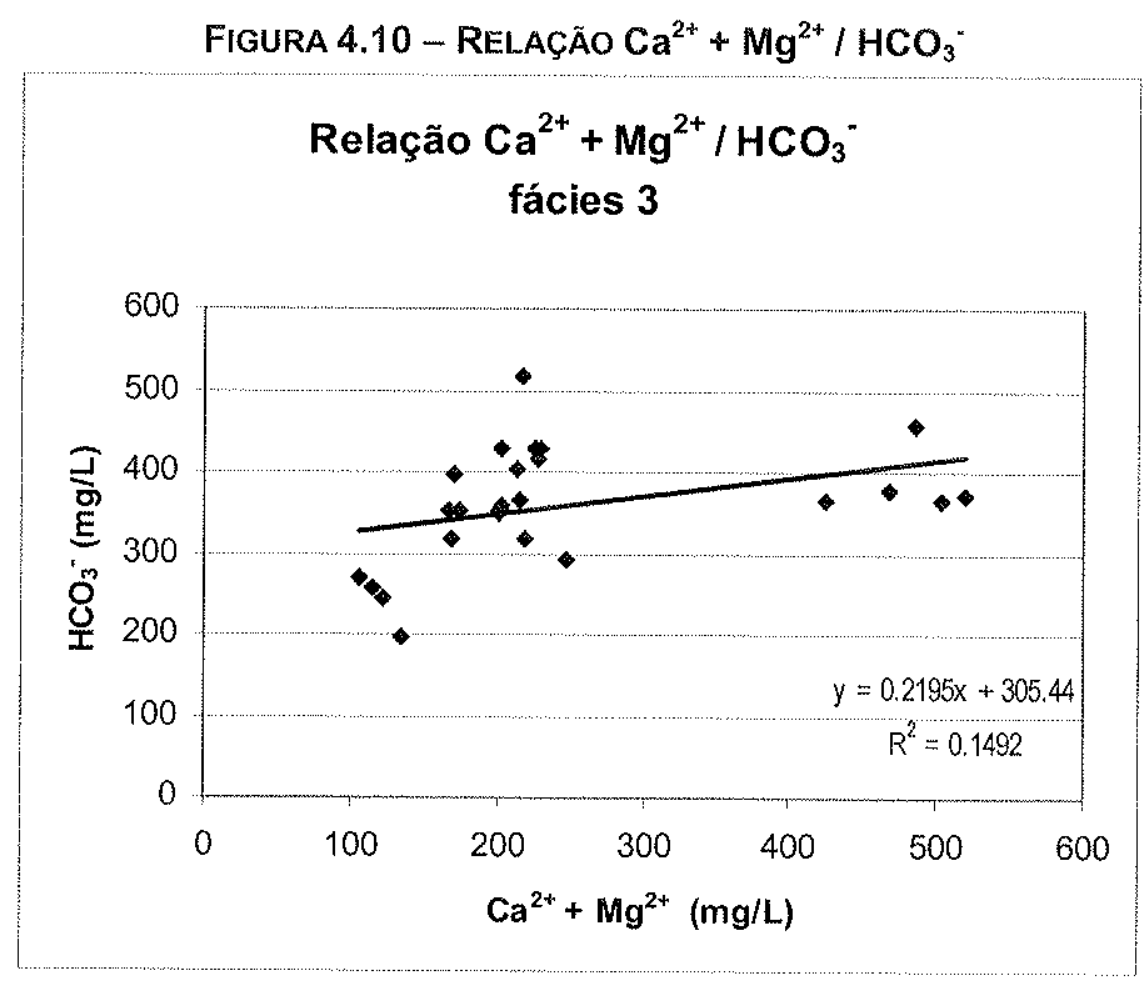

Na fácies 4, percolação vadosa autogênica, um parâmetro que chama atenção é o cloreto, que apresenta altas concentrações em relação a todo conjunto de amostras do carste estudado (figura 4.11). A densidade demográfica na região de estudo é baixa e exatamente sobre os locais de gotejamento não existem moradias, fato constatado através de caminhamento superficial em comparação com dados de mapeamento das grutas envolvidas. Por outro lado, apesar de não existir concentrações pontuais de moradias de forma expressiva, observa-se, sobretudo na região sul, uma distribuição de pequenos vilarejos ao longo da área que podem caracterizar como fatores indutores de influências antrópicas no aqüífero cárstico do Grupo Una, tendo em vista que a população vive de pecuária e lavoura. Nas rochas do Grupo Una não existem minerais que pudessem enriquecer a água de percolação vadosa com altos índices de $\mathrm{NaCl}$. A observação das concentrações de cloreto das águas meteóricas, obtidas neste estudo (tabela 4.3) e em outros na região, também não indicam fornecimento de $\mathrm{NaCl}$ ao sistema (Tavares, 1983; Guerra, 1986; Negrão, 1987). Assim, de posse desta premissa, foi identificado que uma possivel fonte para a alta concentração de $\mathrm{Cl}^{-}$, é um bebedouro de gado localizado a poucas dezenas de metros na superfície sobre um dos pontos de coleta de água de gotejamento, condição esta propícia para a eliminação de sal via urina dos animais. 
A fácies 4 também diferenciamse das demais fácies pela alta concentração de $\mathrm{SO}_{4}{ }^{2-}$ (figura 4.12), sobretudo quando comparada com a concentração de $\mathrm{HCO}_{3}{ }^{-}$. A situação mais freqüente encontrada em percolação vadosa de sistemas cársticos é de alta concentração de $\mathrm{HCO}_{3}{ }^{2}$ em detrimento de outros íons (Ford \& Williams, 1989). A alta concentração de $\mathrm{SO}_{4}{ }^{2-}$ é atribuída a depósitos de $\mathrm{CaSO}_{4}$, existentes nos sistemas de fraturas e interstícios da rocha, hoje na zona vadosa, precipitados anteriormente em posições superiores através de oscilações do nível d'água.

Nitrato em água subterrânea é um forte indicativo de contaminação pó influência humana, tendo em vista que a indução natural é baixa (Appelo \& Postma,1993). Assim, a indução antrópica pode ser dada pela utilização de fertilizantes nitrogenados e por efluentes líquidos de sistemas de esgoto não tratados (fossa negra ou fossa séptica saturada). Na região de estudo, com ênfase para os pontos logo acima dos gotejamentos que exibiram os maiores teores de $\mathrm{NO}_{3}^{-}$(figura 4.14), não há plantação sistemática, o que leva a concluir que não é tão provável a influência por fertilizantes, por outro lado, existem residências em um raio de $200 \mathrm{~m}$ do ponto da superfície imediatamente acima do gotejamento. A boa correlação entre nitrato e cloreto $\left(R^{2}=\right.$ $0,75)$ obtida na fácies 4 , indica ação antrópica.

A fácies 5, representada pelos reservatórios subterrâneos, quimicamente é caracterizada pela alta concentração de $\mathrm{HCO}_{3}^{-}(\bar{x}=305,10 \mathrm{mg} / \mathrm{L}$, figura 4.13), suplantada apenas pela fácies 3 e um pouco superior à fácies 6 . Considerando que o reservatório é alimentado pela fácies de circulação mais profunda, associamse esta diminuição de concentração a um processo de degaseificação, caracterizada pela perda de $\mathrm{CO}_{2}$ para a atmosfera. Destaca-se também a concentração média para $\mathrm{SO}_{4}{ }^{2-}$ $(\bar{X}=17,79 \mathrm{mg} / \mathrm{L} ; \mathrm{CV}=52,03 \%$, figura 4.12$)$, considerada pequena quando comparada a outras fácies do sistema, mas expressiva para este tipo de ambiente, que reflete uma condição de diluição devido à mistura de águas profundas ricas em sulfato com águas freáticas rasas pobres em sulfato.

$\mathrm{Na}$ fácies 6 , nascentes cársticas, chama também a atenção a concentração de $\mathrm{SO}_{4}{ }^{2-}(\bar{x}=19,30 \mathrm{mg} / \mathrm{L} ; \mathrm{CV}=31,47 \%$, figura 4.12$)$, Nesta fácies, a concentração de sulfato significa um valor médio do sistema, pois representa a mistura da água de todas as fácies, por se tratar do exutório do sistema. Com relação ao $\mathrm{HCO}_{3}{ }^{\circ}$, observa-se um decréscimo no valor médio em relação às fácies 5 , relacionado ao contínuo processo $d$ degaiseficação da água subterrânea. 
FIGURA 4.11 - FÁCIES $\times \mathrm{CL}^{\circ}$

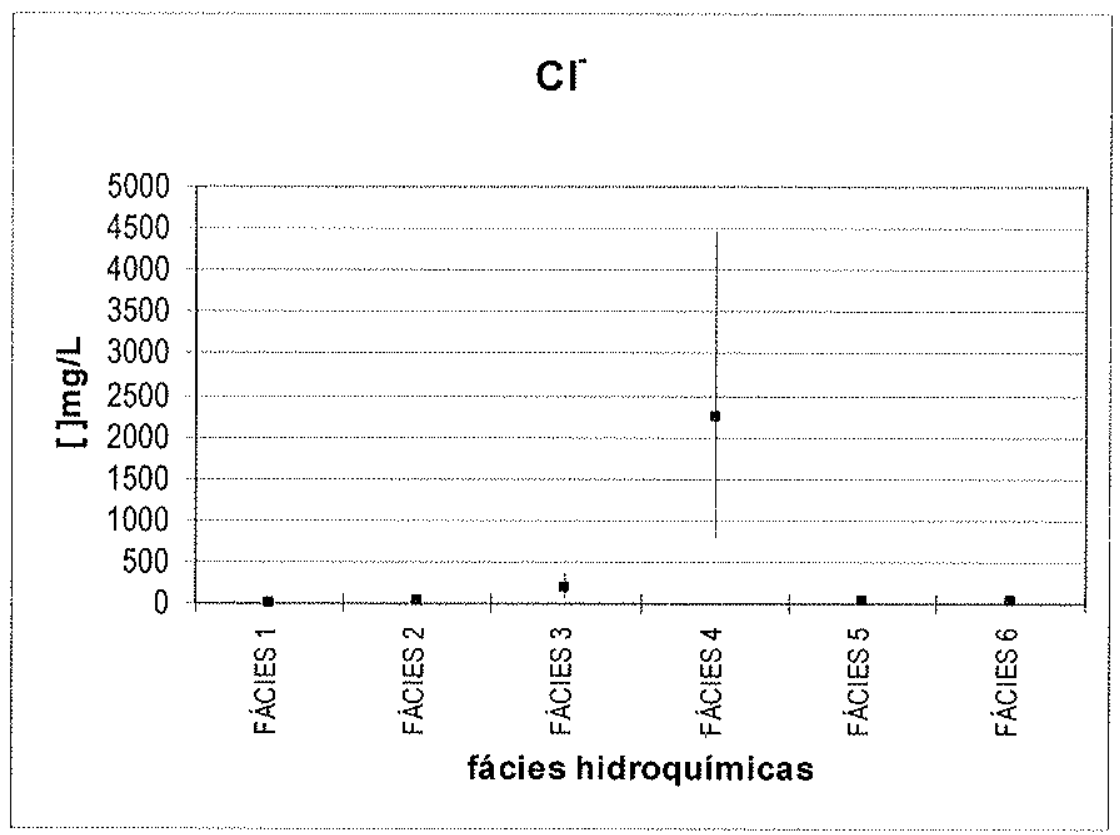

fácies 1 - escoamento alogênico; fácies 2 - fluxo freático profundo não carbonático; fácies 3 - fluxo freático profundo carbonático; fácies 4 - percolação vadosa autogênica; fácies 5 - reservatórios subterrâneos; fácies 6 - nascentes cársticas

FIGURA 4.12 - FÁCIES $\times \mathrm{SO}_{4}{ }^{2-}$

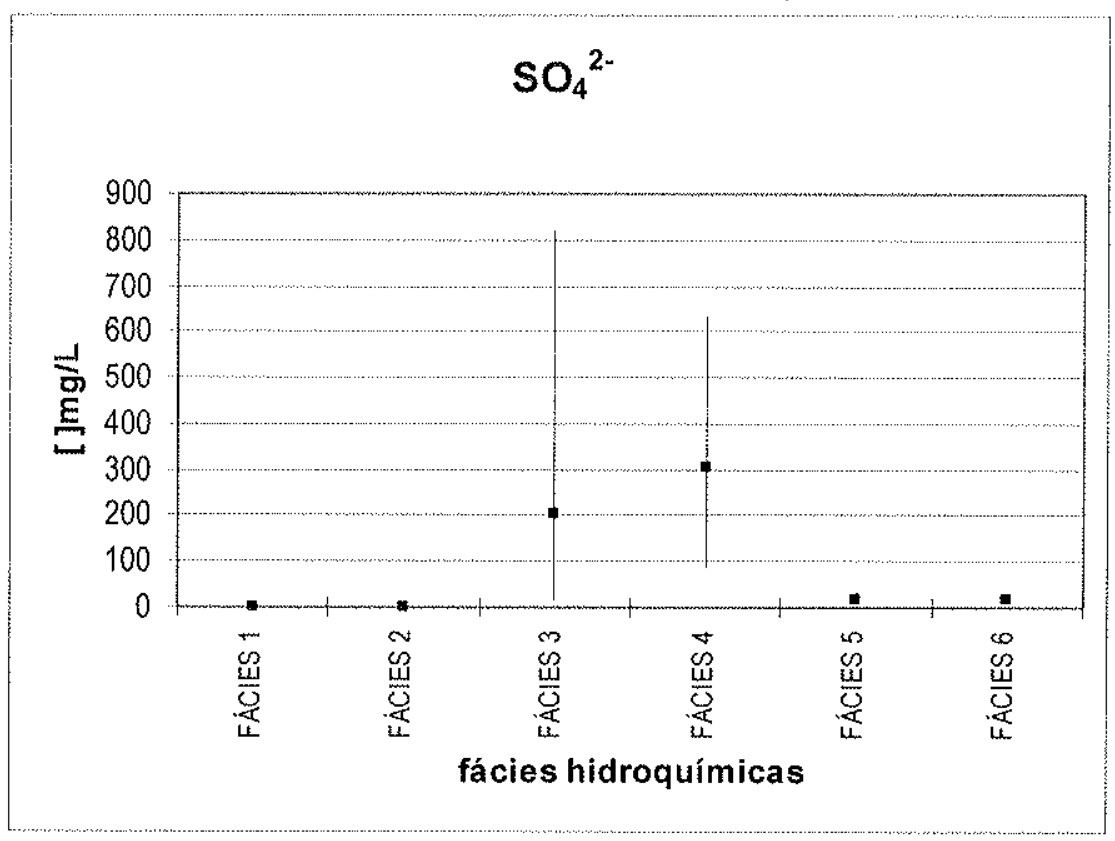


FIGURA 4.13 - FÁCIES $\times \mathrm{HCO}_{3}{ }^{-}$

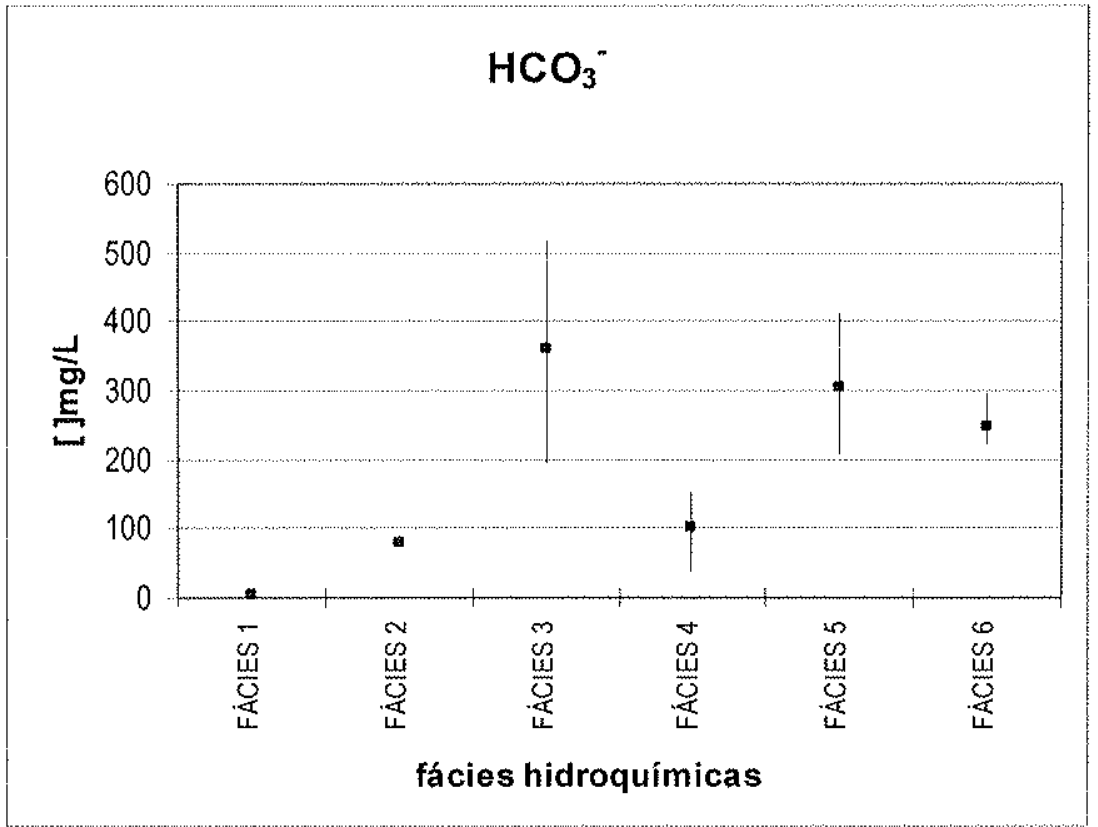

fácies 1 - escoamento alogênico; fácies 2 - fluxo freático profundo não carbonático; fácies 3 - fluxo freático profundo carbonático; fácies 4 - percolação vadosa autogênica; fácies 5 - reservatórios subterrâneos; fácies 6 - nascentes cársticas

FIGURA 4.14 - FÁCIES $\times \mathrm{NO}_{3}^{-}$

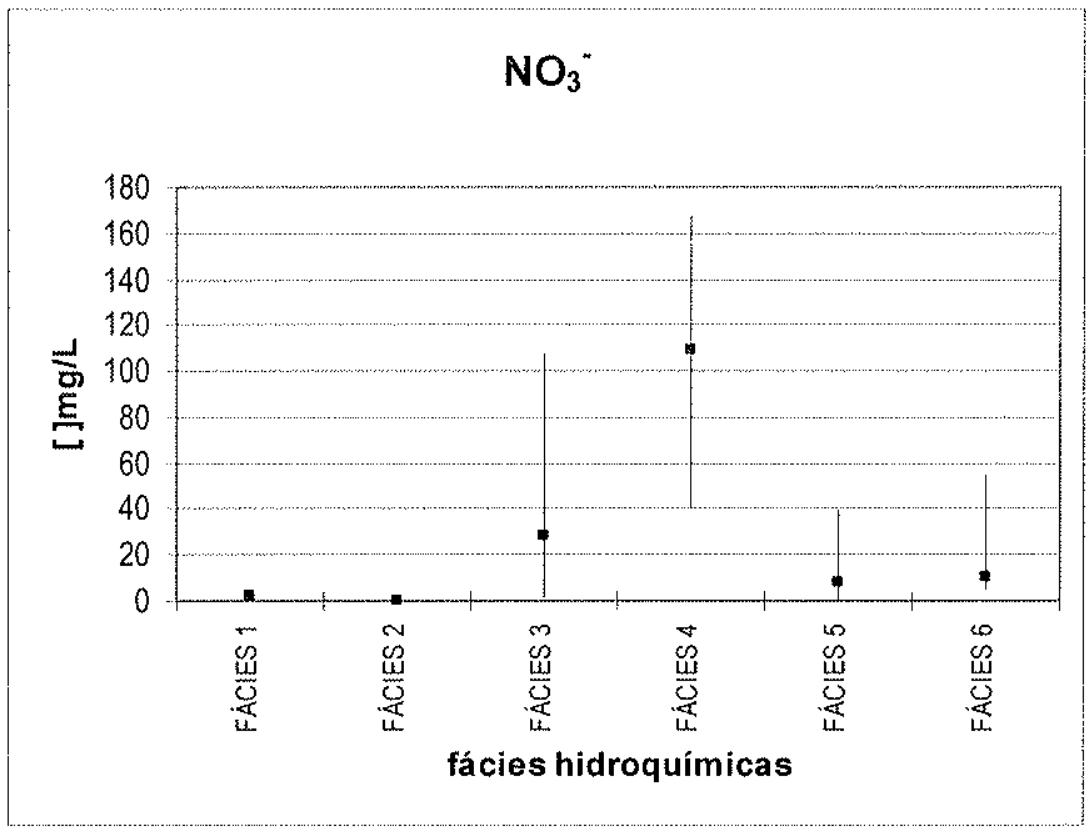

fácies 1 - escoamento alogênico; fácies 2 - fuxo freático profundo não carbonático; fácies 3 - fluxo freático profundo carbonático; fácies 4 percolação vadosa autogênica; fácies 5 - reservatórios subterrâneos; fácies 6 - nascentes cársticas 
Analisando as tabelas 4.4 e 4.5 constata-se que as águas das fácies do sistema cárstico estudado não são operadas exclusivamente pelos mecanismos relacionados com as reações (r.4.1) e (r.4.8), condição atribuída ao fato de não haver nenhum resultado "aceito", mas apenas valores que margeiam os limites relacionados à ação do ácido carbônico. A tabela 4.6 indica a tendência corrosiva principal do sistema cárstico estudado, denotando a ocorrência das reações que envolvem a ação simultânea dos ácidos carbônico e sulfúrico nas rochas carbonáticas. A fácies 3 , fluxo freático profundo carbonático, é a que mais está sujeita à ação do ácido sulfúrico, tendo em vista que as razões molares são compativeis nas relações explicitadas nas tabelas 4.6 e 4.7 . A fácies 4 , percolação vadosa autogênica, não se enquadra em nenhum modelo de

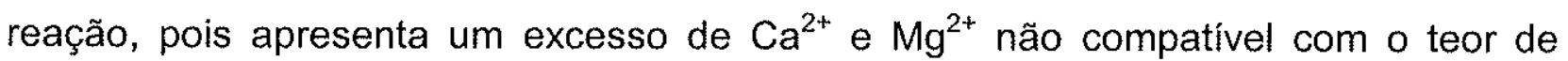
$\mathrm{HCO}_{3}$. Por outro lado, a concentração de $\mathrm{Ca}^{2+}$ e $\mathrm{Mg}^{2+}$ é coerente com a concentração de $\mathrm{SO}_{4}{ }^{2 *}$, o que é relacionado à dissolução de $\mathrm{CaSO}_{4}$ secundário.

Neste sentido, sobretudo em função das características geológicas e hidrogeológicas da área de estudo, a participação do ácido carbônico como agente corrosivo, mesmo que em menor proporção, sempre existe, mas destaca-se que a participação do ácido sulfúrico como agente corrosivo das rochas carbonáticas do carste associado ao Grupo Una é efetiva.

\section{5 - Teste do modelo em um sistema cárstico pobre em sulfato}

Afim de se verificar a eficácia da metodologia utilizada para a constatação da ação do ácido sulfúrico no carste estudado, aplicou-se a mesma nos dados hidroquímicos obtidas por Karmann (1994) e Vianna Jr (2003), referentes ao carste do Alto Vale do Ribeira, Iporanga-SP, reconhecido pelos autores como condicionado à ação corrosiva por ácido carbônico. As águas analisadas por Karmann (1994) compreendem águas de nascentes (Santana), sumidouro autogênico (Pérolas) e fluxo superficial autogênico (Córrego Furnas e Mina de Furnas). As águas analisadas por Viana Jr (2003), correspondem a fluxo em subsuperfície (ESS e AE), percolação vadosa autogência (FR, EE1, EE2, EIF e ESF) e fluxo autogênico subterrâneo (TSF, TIF e TE).

Os resultados da relação $\mathrm{Ca}^{2+}+\mathrm{Mg}^{2+} / \mathrm{HCO}_{3}{ }^{-}$do teste aplicado (tabela 4.8) confirmaram que o carste do Alto Vale do Ribeira é operado exclusivamente pela 
dinâmica corrosiva associada ao ácido carbônico (r.4.1) e (r.4.8), mostrando, desta forma, que a metodologia utilizada é adequada. O critério de validação dos resultados foi o mesmo aplicado ao carste estudado neste trabalho.

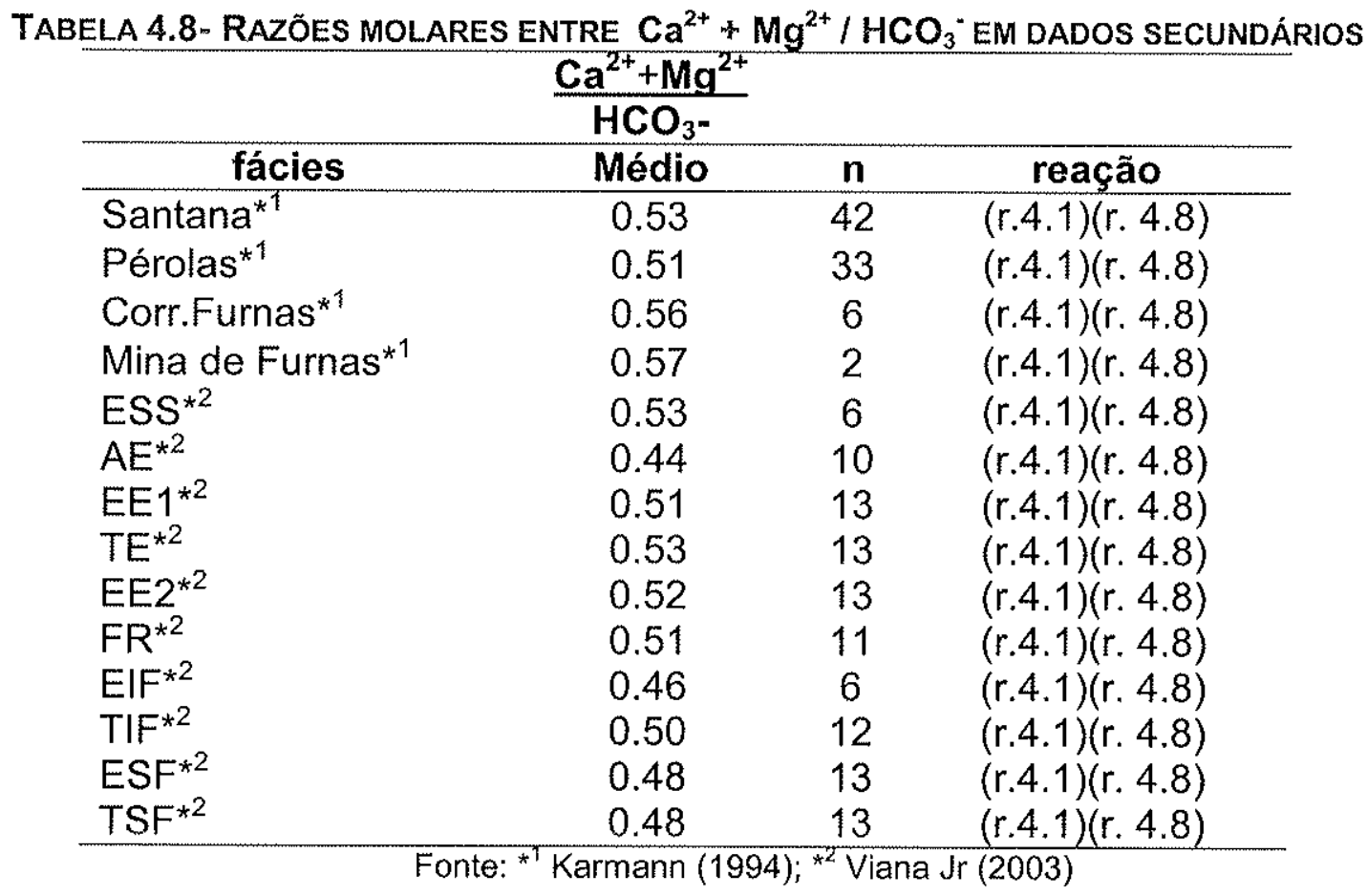




\section{CAPÍTULO 5 - HIDROLOGIA DO SISTEMA CÁRSTICO ESTUDADO}

\section{1 - Introdução}

A carstificação pode ser interpretada como um processo de erosão química, sendo a água subterrânea o principal agente geomórfico primário. Neste sentido, para estimar o fluxo de massa em solução de um sistema cárstico, é fundamental monitorar durante um ano hidrológico o volume de água (solvente) transmitido pelo sistema, com vistas a avaliar o impacto que este agente exerce na rocha encaixante (carbonática). As informações obtidas no referido monitoramento também possibilitam entender o processo de recarga do sistema.

Neste trabalho monitorou-se a vazão de duas nascentes cársticas: Pratinha, na extremidade sul da Bacia de Irecê e Pacuí, localizada na porção norte do Grupo Una, na bacia hidrográfica do rio Salitre. Ambas foram selecionadas por apresentarem vazão perene e altos teores do ín sulfato.

\section{2 - Clima e Pluviometria}

Segundo a classificação climática de Thornthwaite, a área de estudo apresenta clima sub-úmido a semi-árido na bacia de Irecê e semi-árido a árido, na região de Laje dos Negros, com temperaturas médias anuais na faixa de 20 a $23^{\circ} \mathrm{C}$ (INPE/CPTEC, 2003).

$\mathrm{Na}$ caracterização da pluviometria da região foram utilizadas informações adquiridas de pluviômetros instalados na região especificamente para este estudo, como também da base de dados INPE/CPTEC (op.cit). Na Bacia de Irecê existem 95 estações pluviométricas, porém, de 55 destas os dados estão indisponíveis, sendo que apenas 23 estão em operação (Bastos \& Peixoto et al, 2004). Observando as informações percebe-se em quase todas as estações, nas séries históricas, lapsos que denotam deficiência na aquisição da informação, contudo, em 4 estações os dados são consistentes e oferecem a possibilidade de boas correlações. Bastos \& Peixoto et al (op.cit), em estudo regional, constataram que a distribuição das estações pluviométricas atende aos critérios de distribuição espacial preconizado pela Organização Mundial de Meteorologia (OMM), entidade vinculada à Organização das 
Nações Unidas. Neste sentido, observa-se uma variabilidade média bem definida ao longo dos meses, com estações chuvosas entre novembro e março e periodos de seca no intervalo subseqüente. Sob a ótica espacial, as chuvas concentram-se nas áreas centrais, com tendência de menores índices pluviométricos nas porções a norte. Considerando os dados históricos disponiveis (20 anos), observa-se uma variação nas médias de precipitação entre 1040mm e 510mm (Bastos \& Peixoto et al, op cit).

Através da integração dos dados pluviométricos regionais do planalto cárstico, obtidos junto ao INPE/CPTEC (2003), nota-se baixos índices pluviométricos (de 510 a $1040 \mathrm{~mm}$ ), as chuvas possuem distribuição irregular tanto do ponto de vista geográfico como também dos totais anuais ao longo dos últimos 20 anos. O mapa da figura 5.1 ilustra uma carta de isoietas da região para o ano de 2003. Foram calculados também os balanços hídricos dos municípios da Bacia de Irecê, que mostram expressivo déficit (quadro 5.1). A figura 5.2 destaca o balanço hídrico para o município de Iraquara, localidade onde se encontra a principal nascente da área de estudo. A oeste da área de estudo, sobre os metarenitos do Grupo Chapada Diamantina, observa-se, com base nos dados de precipitação $(P)$ e evapotranspiração potencial (EP) obtidos junto ao INPE/CPTEC (2003), que a pluviometria anual é maior e com distribuição intra-anual mais regular do que no planalto cárstico. A figura 5.3 destaca o balanço hídrico do município Brotas do Macaúba, localizado sobre os metarenitos.

QUADRO 5.1 - DEFICIT HIDRICO DOS MUNICIPIOS DA BACIA DE IRECE

\begin{tabular}{|l|r|}
\hline \multicolumn{1}{|c|}{ Município } & \multicolumn{1}{c|}{ déficit } \\
\hline Lapão & -1222.99 \\
\hline Palmeiras & -764.33 \\
\hline Jussara & -1315.79 \\
\hline Ourolândia & -1205.26 \\
\hline Xique-xique & -1316.13 \\
\hline Utinga & -807.96 \\
\hline João Dourado & -1324.43 \\
\hline Seabra & -901.7 \\
\hline Souto Soares & -926.63 \\
\hline Morro do Chapéu & -1087.67 \\
\hline Irecê & -1373.81 \\
\hline Iraquara & -804.34 \\
\hline Mulungú do Morro & -848.5 \\
\hline Ibititá & -1276.86 \\
\hline
\end{tabular}

\begin{tabular}{|l|r|}
\hline \multicolumn{1}{|c|}{ município } & \multicolumn{1}{c|}{ déficit } \\
\hline Barro Alto & -1200.93 \\
\hline Central & -1259.37 \\
\hline Canarana & -909.28 \\
\hline Cafarnaum & -894.73 \\
\hline Barra do Mendes & -1096.94 \\
\hline América Dourada & -1215.23 \\
\hline Ibitiara & -714.5 \\
\hline Jacobina & -934.09 \\
\hline Lencois & -704.61 \\
\hline Ibipeba & -1361.8 \\
\hline Varzea Nova & -1109.06 \\
\hline Presidente Dutra & -1296.33 \\
\hline Uibai & -1289.3 \\
\hline São Gabriel & -1337.6 \\
\hline
\end{tabular}


Segundo classificação de zoneamento climático de Hargreaves (1994), que define o índice de umidade (MAI -Moisture Availability Index), pela relação entre precipitação e a evapotranspiração potencial (P/EP), a região de estudo apresenta clima árido e semi-árido (figura 5.4). O balanço hídrico para o município de Iraquara (figura 5.5), ano base 2003, mostra que a região apresentou um déficit hídrico de 8 meses (fevereiro a julho e setembro a outubro) e uma pequena recarga somente durante 2 meses (parte de outubro, novembro e parte de dezembro), sendo que nos meses restantes houve equilibrio entre retirada e reposição. Assim, considerando que a área abrangida por este município compõe uma porção representativa das condições ambientais do extremo sul da bacia de Irecê, estende-se esta característica de baixa recarga para toda área do planalto cárstico. Com base nos balanços hídricos obtidos para os municípios a norte de Iraquara, observa-se uma tendência de diminuição de recarga neste sentido. Não foi possível obter balanços hídricos para a região da bacia do rio Salitre em função da insuficiência de informações, porém, com as poucas obtidas, pode-se constatar uma situação de recarga igual ou pior à da bacia de Irecê.

\section{3 - Hidrologia de superfície da área de estudo}

A rede de drenagem da área de estudo é composta pelas bacias dos rios Jacaré, Verde e Salitre, que drenam para o rio São Francisco e a bacia do rio Santo Antônio, afluente do Alto Paraguaçu.

Nos domínios da Bacia de Irecê, sobre os calcários, as drenagens superficiais são raras. Na porção Sul as drenagens que se destacam são: os riachos Água de Rega, das Almas e do Gado, que nascem nos metarenitos do Grupo Chapada Diamantina, a oeste, percorrendo em superficie até os sumidouros no contato com as rochas carbonáticas, continuando sobre os calcários, na forma de vales secos de fundos amplos recobertos por sedimentos e apresentando escoamento superficial apenas em episódios de intensas chuvas; e o rio Santo Antônio, oriundo das serras metareníticas da porção sul da bacia de Irecê, segue na direção NNE com inflexão brusca para leste nas proximidades da nascente da Pratinha, indo em direção leste atravessando os metarenitos. É alimentado pelo rio Cochó e principalmente pela nascente da Pratinha, onde adquire caráter pleno de perenidade (figura 3.1). 
FIgURA 5.1 - CARTA DE ISOIETAS BACIA DE IRECÊ - ANO BASE 2003

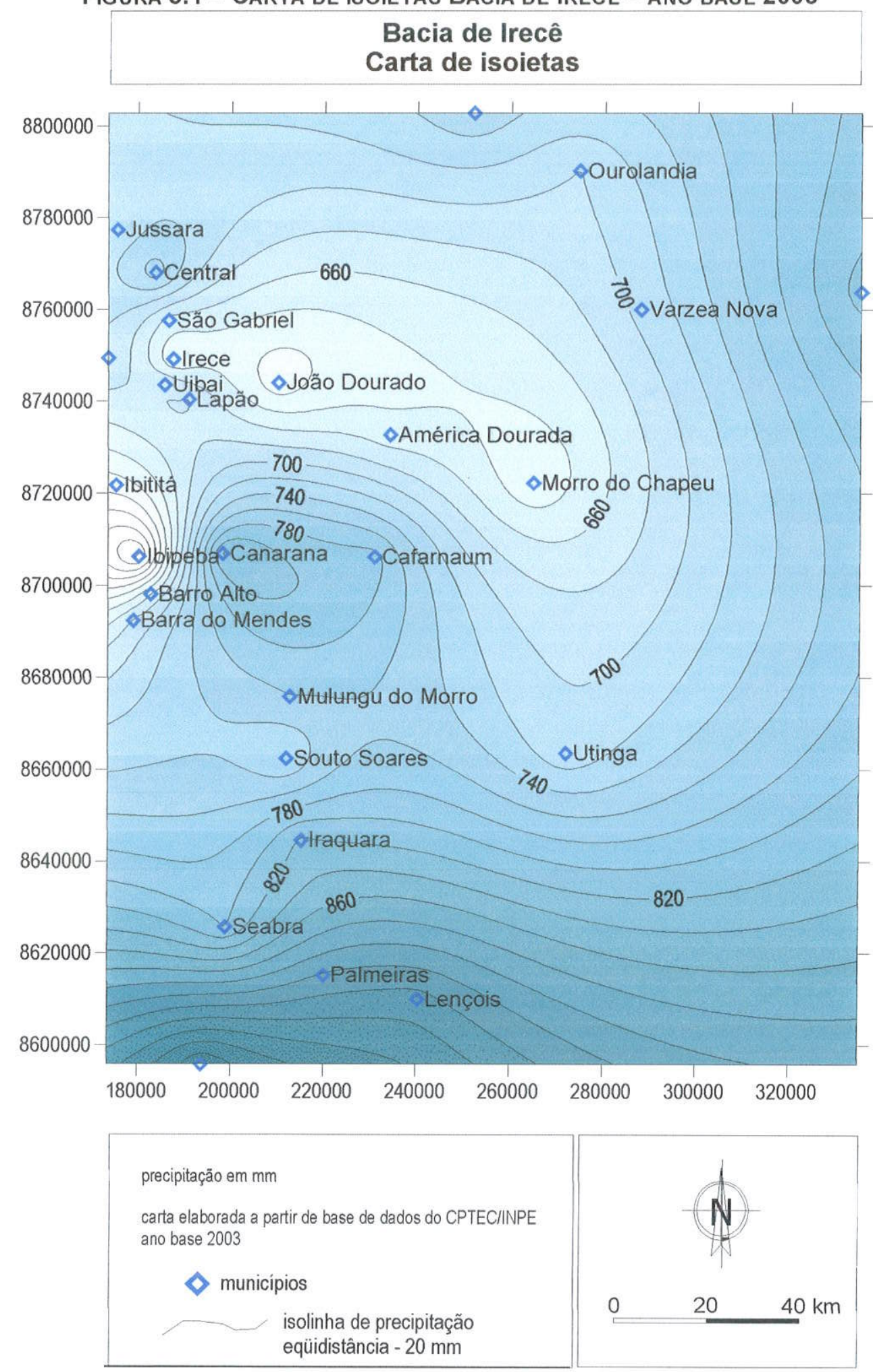


FIGURA 5.2- BALANÇO HÍDRICO DO MUNICÍPIO DE IRAQUARA-BA

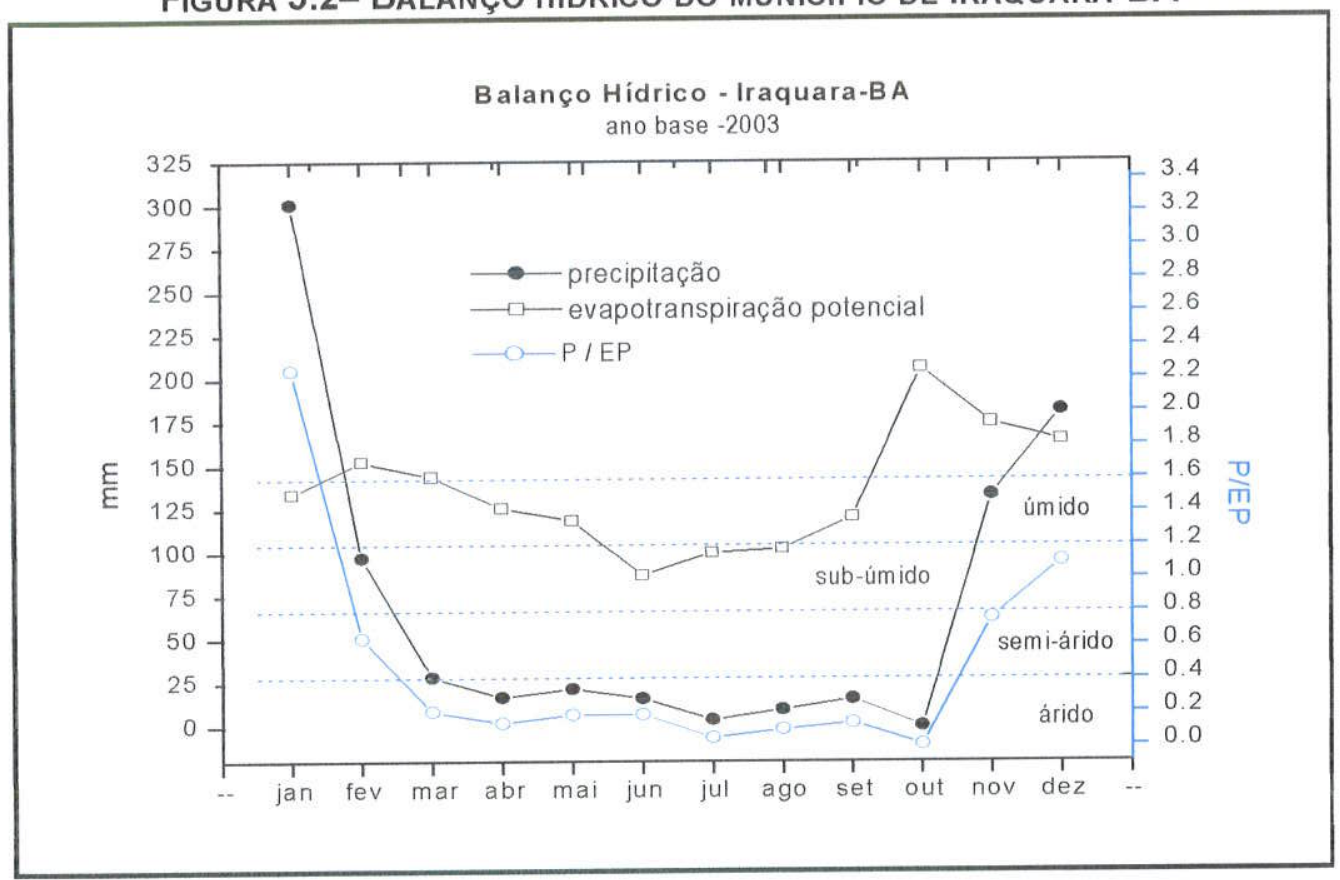

FIGURA 5.3- BALANÇO HÍDRICO DO MUNICÍPIO DE BROTAS DO MACAÚBA-BA

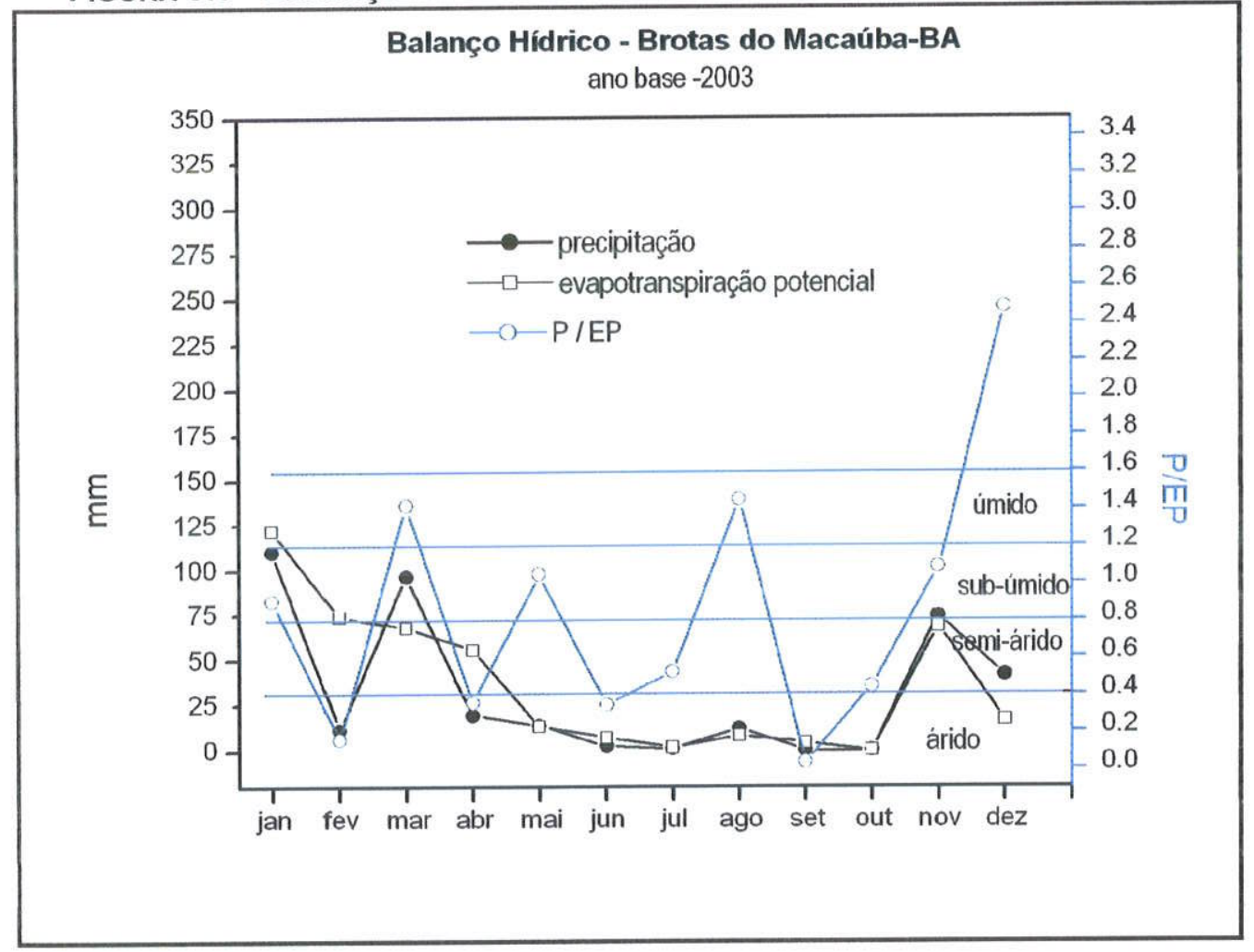


FIGURA 5.4 - MAPA DE ISOLINHAS DE PIEP - BACIA DE IRECÊ

\section{Bacia de Irecê} P / EP

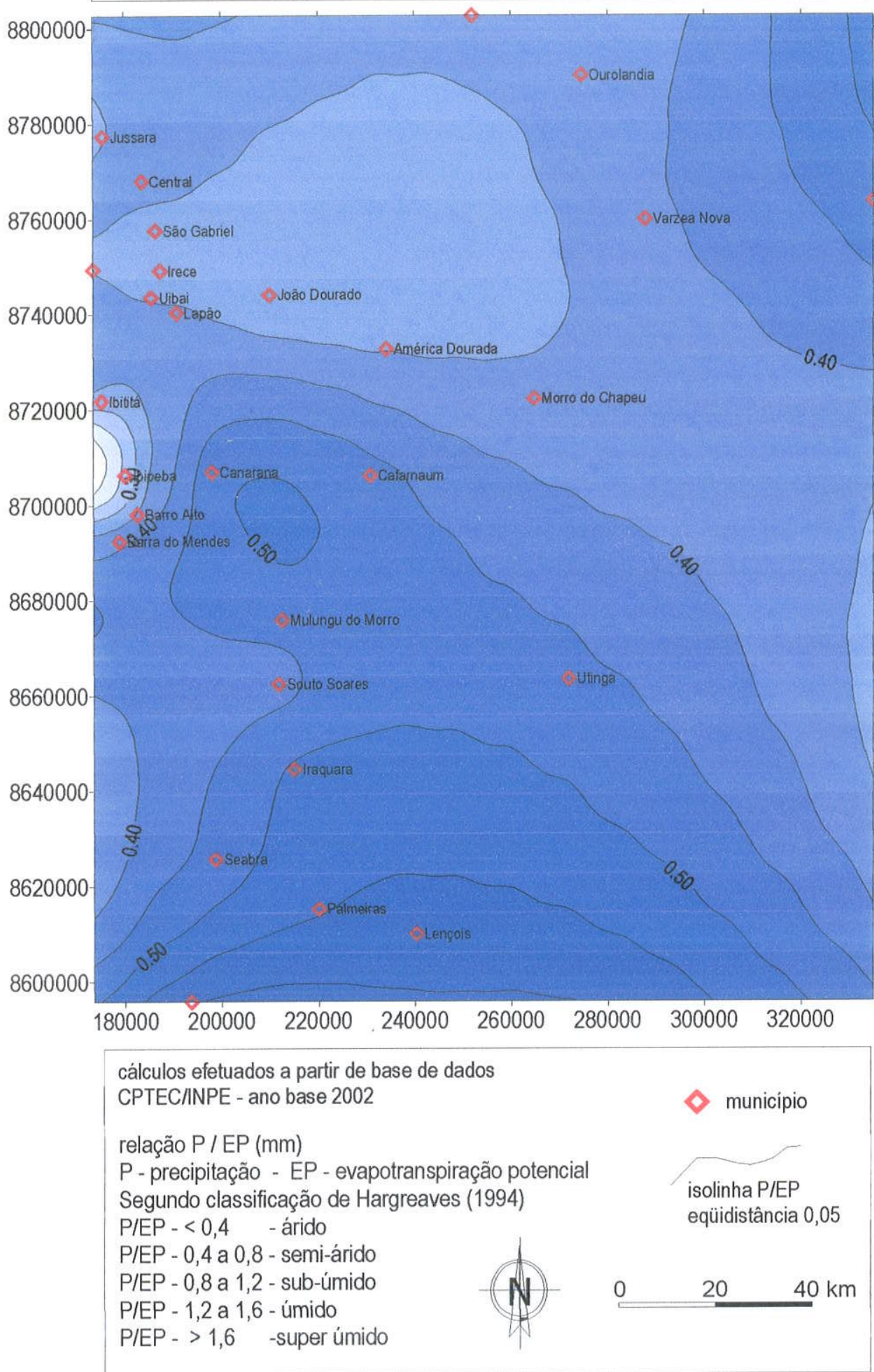




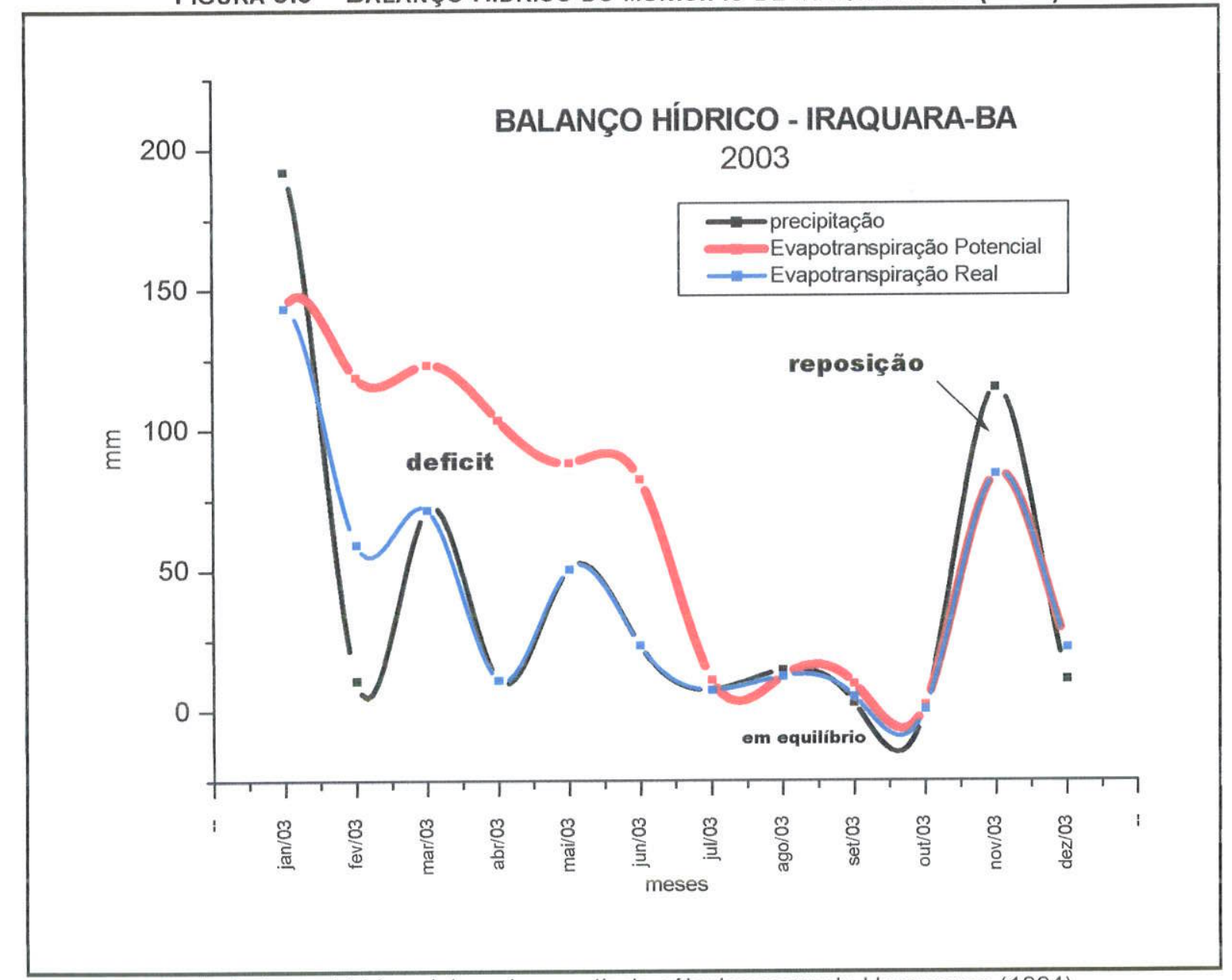

nota: balanço hídrico elaborado a partir de cálculos segundo Hargreaves (1994)

Na porção norte da bacia de Irecê a drenagem que se destaca é o Rio Jacaré, que nasce na borda ocidental da bacia, nos domínios das rochas do Grupo Chapada Diamantina, nas imediações do município de Barra do Mendes. É um rio intermitente, tendo seu regime associado aos máximos pluviométricos de sua bacia hidrográfica. Este fato é evidenciado pelos inúmeros represamentos naturais observados ao longo de sua calha, com intercalações de trechos secos.

De um modo geral, o planalto cárstico de Irecê, caracteriza-se por baixo gradiente hidráulico, como por exemplo o medido para o riacho Água de Rega que, entre seu sumidouro e a provável ressurgência na gruta Pratinha, apresenta um gradiente hidráulico de $0,28 \%(2,8 \mathrm{~m} / \mathrm{km})$.

A bacia do rio Salitre, afluente da margem direita do rio São Francisco, nasce nas imediações do município de Morro do Chapéu, é caracterizada por um conjunto de 
rios que mantém-se secos ao longo dos anos com reativação motivadas por altas pluviométricas. Seu percurso é caracterizado por uma expressiva variação de largura e profundidade, que por muitas vezes faz com que as águas tenham o trajeto descontínuo. A utilização da água para fins humanos também é um condicionante para a diminuição e redução da vazão ao longo de seu percurso. O extremo norte do Grupo Una e da bacia do rio Salitre, encontra-se em uma das regiões mais áridas do estado da Bahia e destaca-se na região a nascente do rio Pacuí, que por manter-se com fluxo o ano inteiro, permite que o rio Salitre seja perene a partir deste ponto até a foz.

De um modo geral, na área de estudo, as informações fluviométricas são escassas. Segundo informações obtidas junto a ANA (Agência Nacional de Águas) sete estações fluviométricas integram a sub-bacia 47, do rio São Francisco, sendo que não há informações disponiveis para duas destas e apenas quatro estão em operação. Segundo estudos coordenados por Bastos \& Peixoto et al, 2004, a distribuição de estações fluviométricas não atende as recomendações da OMM, sobretudo por tratarse de uma região cárstica.

\section{4 - Hidrologia subterrânea da área de estudo}

\subsection{1 - Introdução}

Os aqüiferos cársticos, em decorrência de seus processos genéticos, são distintos, pois exibem caracteristicas hidrogeológicas e hidrológicas diferenciadas, em função da presença de uma rede de condutos subterrâneos e fraturas, responsáveis pela transmissão do fluxo da água nas zonas freática e vadosa (White,1988). A região cárstica do presente estudo foi, ao longo das últimas duas décadas, estudada por diversos pesquisadores, sob o ponto de vista hidrogeológico. Siqueira (1978), que estudou o uso de dados isotópicos e químicos como indicadores da origem das águas e sais dissolvidos no aqüífero relacionado ao Grupo Una, concluiu que as águas de recarga são originadas de precipitações dirigidas de NE para SW; observou ainda, que a recarga predominantemente ocorre rapidamente por meio do sistema de fraturas, condição atestada pela ausência de variação isotópica de água subterrânea relacionada à evaporação. Cabral (1978), a partir do estudo de isótopos de carbono, observou que parte expressiva das águas analisadas na Bacia de Irecê tem idades 
modernas e que a recarga é efetuada por águas de precipitação, com base em datações ${ }^{14} \mathrm{C}$. Destaca ainda, que em determinados setores existem águas com idades de até 13000AP, condição que pode atestar a ocorrência de fluxos lentos ou mesmo a presença de reservatórios subterrâneos isolados do sistema principal de fraturas e condutos. Gomes (1978), aplicando isótopos naturais de Urânio como traçadores, estabeleceu um modelo coincidente com o descrito por Cabral (1978). Guerra (1986) desenvolveu um amplo estudo sobre os processos de carstificação e a hidrogeologia no Grupo Una na Bacia de Irecê, concluindo que o comportamento hidrogeológico geral ajusta-se ao quadro evolutivo de um sistema cárstico, observando na região norte um aqüífero cárstico/fissural com um aumento gradativo da influência dos fenômenos cársticos no sentido sul e borda oriental da bacia. Estabeleceu ainda que a taxa média de recarga é da ordem de $3,9 \%$ das precipitações. Negrão (1987) caracterizando o sistema cárstico associado à Bacia de Irecê sob a ótica hidroquímica e de vulnerabilidade do aqüífero, concluiu que o sistema hidrológico estudado tem profundidade média de $75 \mathrm{~m}$, sendo caracterizado por grandes canais de circulação, interligados entre si por rios engrunados, compartimentos aqüiferos fissurais/cársticos que por muitas vezes geram estanqueidade. Estes canais estão representados pelos rios Cochó, Jacaré e outros que margeiam o contato com os metarenitos do Grupo Chapada Diamantina. Em síntese, definiu três principais zonas do fluxo da água subterrânea, sendo: região de Souto Soares para sul (bacia do Paraguaçu); Souto Soares a norte até Rio Jacaré (bacia do São Francisco); domo de Irecê, tendo o rio Jacaré ao sul como área de descarga e ao norte a calha do rio São Francisco. Estudos recentes, realizados através de convênio firmado entre a Secretaria de Recursos Hídricos do Estado da Bahia e a UFBA, coordenados por Rogério Bastos e Heraldo Peixoto (Bastos \& Peixoto et al, 2004) e com a utilização de técnicas modernas de estudo e modelamento matemático do fluxo subterrâneo, refinaram e ampliaram o entendimento sobre a dinâmica subterrânea no aqüifero cárstico associado ao Grupo Una. Para o modelamento matemático foram utilizadas informações de 95 poços tubulares situados na sub-bacia de Iraquara que em conjunto com informações de geoprocessamento permitiu o estabelecimento de um mapa potenciométrico que, segundo definição dos autores, necessita aprimoramentos. Dois grandes problemas residem no estabelecimento de um mapa potenciométrico fidedigno e confiável para a Bacia de Irecê: o conhecimento do efetivo valor da altitude do poço, tendo em vista a 
base cartográfica disponivel (IBGE 1:100.000/1:250.000) e o reconhecimento de que a água captada reflete um nível freático regional. Inúmeros poços têm mais de uma entrada de água com diferenças métricas entre as mesmas, condição relacionada, sobretudo, a condutos e fissuras que nem sempre são interconectados. Campanhas de trabalho da SUDENE e CERB efetuaram levantamentos sistemáticos de cotas altimétricas de poços e o resultado pode ser observado no mapa da figura 5.6, que foi elaborado utilizando-se o programa Surfer (v8.0) por interpolação através do método de "krigagem".

De um modo geral as linhas de fluxo, na porção centro-sul da Bacia de Irecê, são coincidentes às direções dos sistemas de cavernas, que na margem esquerda do rio Santo Antônio demonstram fluxo geral de NW para SE, nos sistemas Lapa Doce e Torrinha e N-S na gruta do Diva, demonstrando convergência do escoamento da água subterrânea no sentido da nascente da Pratinha, confirmando que este é o principal exutório do sistema cárstico do setor sul da Bacia de Irecê. As grutas na margem oposta indicam sentido geral de fluxo de SE para NW, a exemplo das cavidades denominadas loiô e Impossivel. No mapa da figura 5.6, observa-se que o limite do divisor subterrâneo das águas esta posicionado mais a norte do que o estabelecido por Guerra (1986), condição que pode ser justificada pela qualidade das informações atuais e das ferramentas de análise. Na porção central e centro norte da Bacia de Irecê, o sentido do fluxo ainda não está bem estabelecido. Este fato é principalmente conseqüência da inconsistência dos dados disponíveis. Vale ressaltar, que a análise de mapas potenciométricos de regiões cársticas deve receber atenção especial, principalmente em função das variações bruscas do nível d'água, que está predominantemente associado às redes de condutos e protocondutos (Ford \& Williams, 1989).

\subsection{2 - Hidrologia da nascente Pratinha}

A variação do nivel do rio da nascente da Pratinha foi monitorada ao longo de 14 meses (julho de 2002 a setembro de 2003). Foram realizadas cinco medidas de vazão para este estudo, distribuídas em intervalos de tempo regulares, buscando acompanhar as variações das estações do ano (figura 5.7). 
FIGURA 5.6 - MAPA POTENCIOMÉTRICO DA BACIA DE IRECÊ

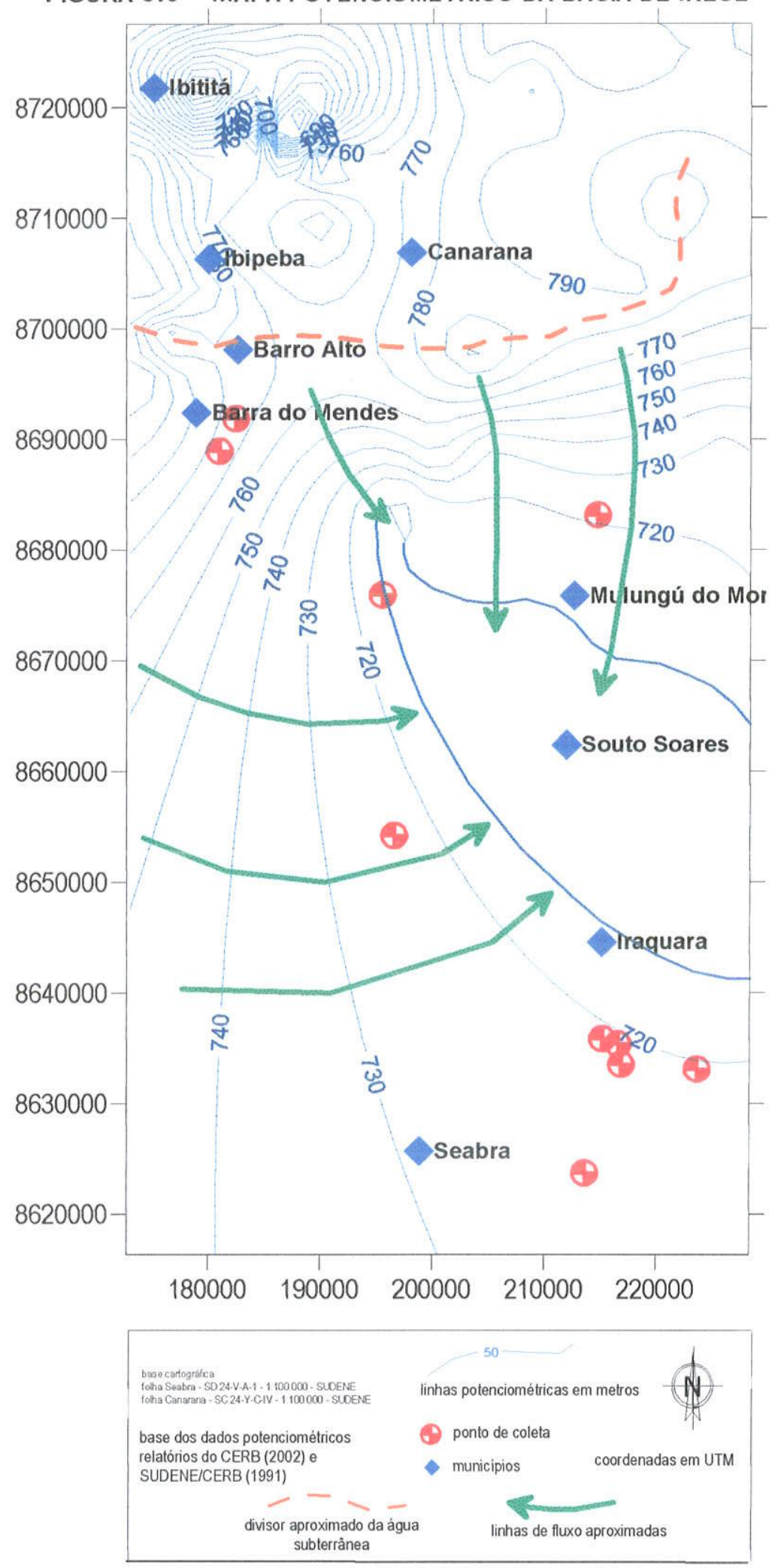


A curva-chave foi determinada considerando a função linear $Q=a A+b$, onde $Q$ é a vazão medida em $\mathrm{m}^{3} / \mathrm{s}$ e $A$ é a altura em metros da lâmina d'água em relação ao datum estabelecido na régua graduada instalada. Assim, para a nascente da Pratinha, com base nas informações da tabela 5.1 obteve-se a equação a seguir.

$$
\mathbf{Q}=1,5596 \mathbf{A}+0,7779 \text { com } R^{2}=0,9812
$$

\begin{tabular}{|c|c|c|c|}
\hline & mès & altura da régua & $Q\left(m^{3} / s\right)$ \\
\hline & $\mathrm{jul} / 02$ & 590 & 0.778 \\
\hline & out/02 & 591 & 0.805 \\
\hline & $\mathrm{jan} / 03$ & 595 & 0.837 \\
\hline & mai/03 & 601 & 0.957 \\
\hline & set/03 & 587 & 0.731 \\
\hline
\end{tabular}

Figura 5.7 - Curva Chave para a Nascente da Pratinha

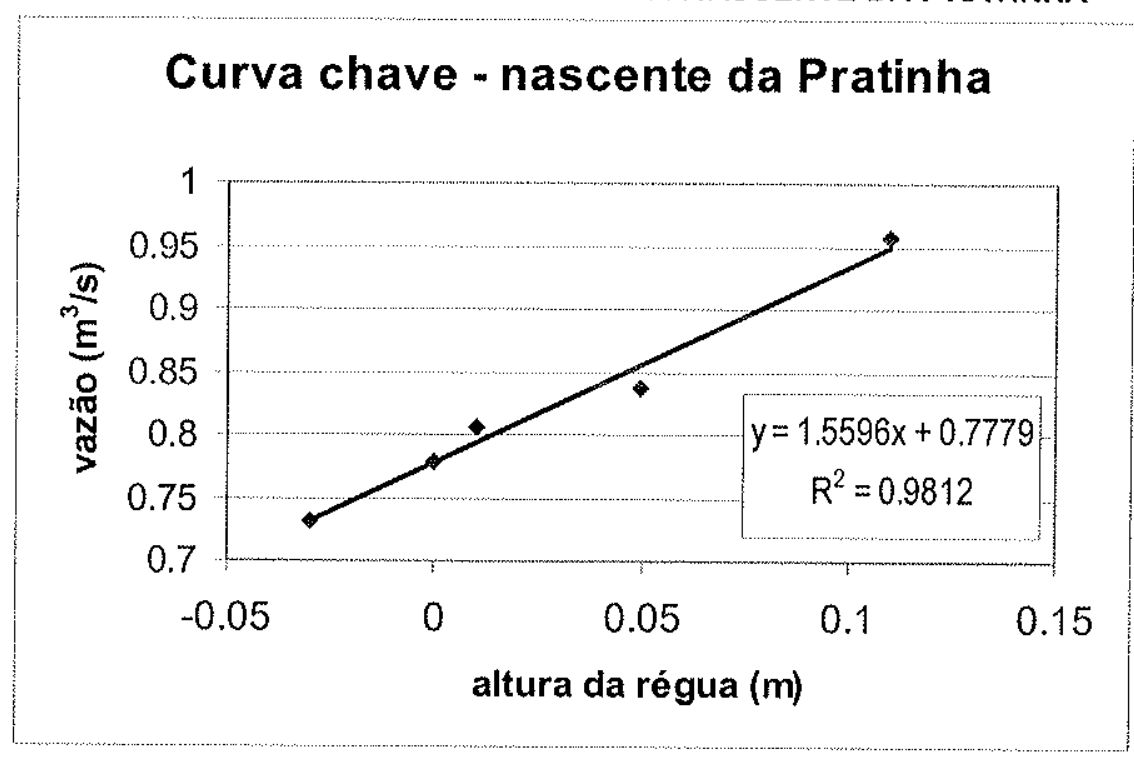

Com base na equação acima, transformou-se a curva de variação do nível d'água versus tempo na curva de vazão instantânea em função do tempo (fluviograma, figura 5.8), que pode fornecer informações sobre a dinâmica do fluxo da água no aqüífero, bem como características físicas associadas ao seu sistema de condutos (Milanovic, 1981). A tabela 5.2 mostra alguns parâmetros hidráulicos obtidos para a nascente da Pratinha, tendo como base o fluviograma (figura 5.8), correspondente ao período de 27/07/2002 a 8/09/2003. Os cálculos de volumes escoados envolvem um erro estimado de até $15 \%$ (Garcez, 1967), decorrente das medidas de vazão, pois 
estas possuem uma incerteza causada pelas condições naturais do local de medição, tais como regime de fluxo turbulento e seção com fundo irregular.

TABELA 5.2 - PARÂMETROS HIDROLÓgICOS DA NASCENTE dA PRATINHA

\begin{tabular}{lcc}
\hline Vazão média & $\mathbf{Q}_{\operatorname{med}}$ & $0,859 \mathrm{~m}^{3} / \mathrm{s}$ \\
Vazão máxima & $\mathbf{Q}_{\max }$ & $1,222 \mathrm{~m}^{3} / \mathrm{s}$ \\
Vazão mínima & $\mathbf{Q}_{\min }$ & $0,751 \mathrm{~m}^{3} / \mathrm{s}$ \\
Razão entre $\mathrm{Q}_{\max } / \mathrm{Q}_{\min }$ & $\mathbf{Q}_{\max } / \mathbf{Q}_{\min }$ & $1,627 \mathrm{~m}^{3} / \mathrm{s}$ \\
\hline Volume total escoado (406 dias) & $\mathrm{Vt}$ & $26.589 .767,62 \mathrm{~m}^{3}$ \\
Volume de escoamento direto & $\mathrm{Vd}$ & $5.178,82 \mathrm{~m}^{3}(0,02 \%)$ \\
Volume de escoamento básico & $\mathrm{Vb}$ & $26.584 .767,80 \mathrm{~m}^{3}(99,98 \%)$ \\
\hline
\end{tabular}

Segundo Worthington (1991), que estabelece uma classificação de nascentes cársticas em função das características de vazão, através da razão $Q_{\max } / Q_{\min }$, a nascente da Pratinha enquadra-se no tipo Fluxo Total Permanente (full flow), por exibir valor alto e apresentar ao longo do ano $Q>0$.

Foi também instalado outro medidor digital de nível d'água na gruta Lapa Doce, cavidade situada a cerca de $5 \mathrm{~km}$ à montante da nascente da Pratinha, onde ocorre um afloramento da água subterrânea junto a um conduto que prossegue em ambiente freático. O objetivo principal deste monitoramento foi estabelecer uma comparação (ou não) entre a variação do nível d'água no interior do aqüifero cárstico com a variação monitorada no exutório do sistema, uma vez que ainda não há uma comprovação de conexões entre sumidouros e nascentes, definindo rotas de fluxo da água subterrânea no setor sul da Bacia de Irecê.

A correlação entre a variação do nível d'água da nascente da Pratinha e da gruta Lapa Doce (figura 5.9), confirma a hipótese de que há uma conexão, tipo vaso comunicante, entre o conduto da nascente e a rede de condutos da gruta lapa Doce, indicando que a nascente realmente é o exutório principal do sistema cárstico, fato importante para suportar a discussão entre as variações hidroquímicas sazonais da nascente e sua relação com o aqüífero. 
Figura 5.8 -Fluviograma da NAscente dA PRATINHA - IRAQUARA-BA

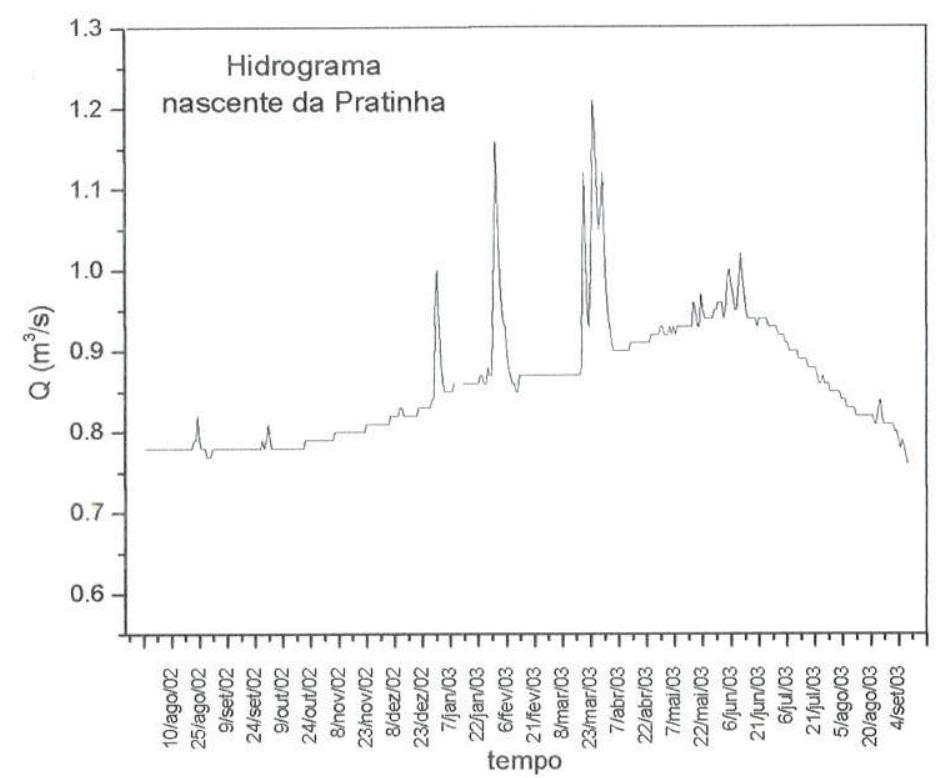

FIGURA 5.9 - COMPARAÇÃO DIRETA ENTRE VARIAÇÃO DOS NIVEIS OBSERVADOS NA GRUTA LAPA DOCE, SISTEMA GRUTA AZUL-PRATINHA E PLUVIOMETRIA

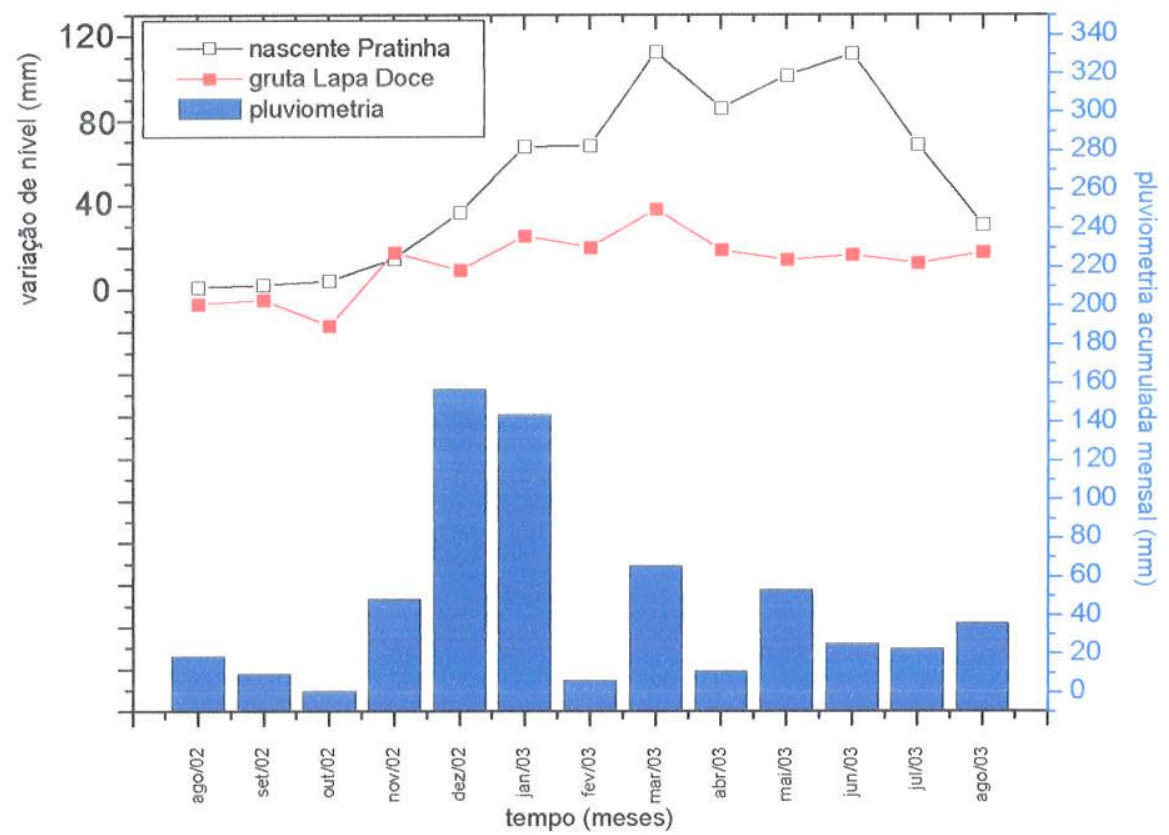


Apesar da correlação visual que existe entre a variação do nivel d'água da nascente da Pratinha e da gruta Lapa Doce, ela não é perfeita (figura 5.9). Comparando as curvas de variação de nível d'água (figura 5.9), nota-se uma maior homogeneidade da curva da Lapa Doce em relação à nascente da Pratinha, que indica a ocorrência de eventos de variação de nível registrados na nascente da Pratinha que não ocorreram na Lapa Doce. Isto é interpretado como indicação de que existem contribuições de água na Pratinha as quais não influenciam o sistema na Lapa Doce.

Através do monitoramento de chuva realizado com pluviômetros instalados nos municípios de Iraquara e Barro Alto, observa-se, na análise temporal dos dados através da utilização da ferramenta estatística correlação cruzada, que as chuvas de Iraquara e Barro Alto demonstram boa correlação (índice de Pearson $\mathrm{R}=0,84$ ), condição que mostra que as incidências pluviométricas têm caráter regional. Observou-se que a resposta das chuvas nas variações dos níveis da ressurgência e do reservatório monitorados é da ordem de 3 dias (figuras 5.10 e 5.11), onde se destaca na correlação da nascente da Pratinha um efeito de variação relacionado com a influência de injeção de água de um outro evento fora da área de controle. Cabe destacar que, no que diz respeito à recarga, os níveis pluviométricos baixos (inferiores a $10 \mathrm{~mm}$ ) não provocam oscilações nos níveis d'água. A relação entre as taxas de recarga e a amplitude das variações anuais observadas na gruta Lapa Doce $(+/-5 \mathrm{~cm} / \mathrm{ano})$ permite concluir a existência de um reservatório de grande porte nas rochas carbonáticas, com recarga subterrânea e difusa através dos metarenitos.

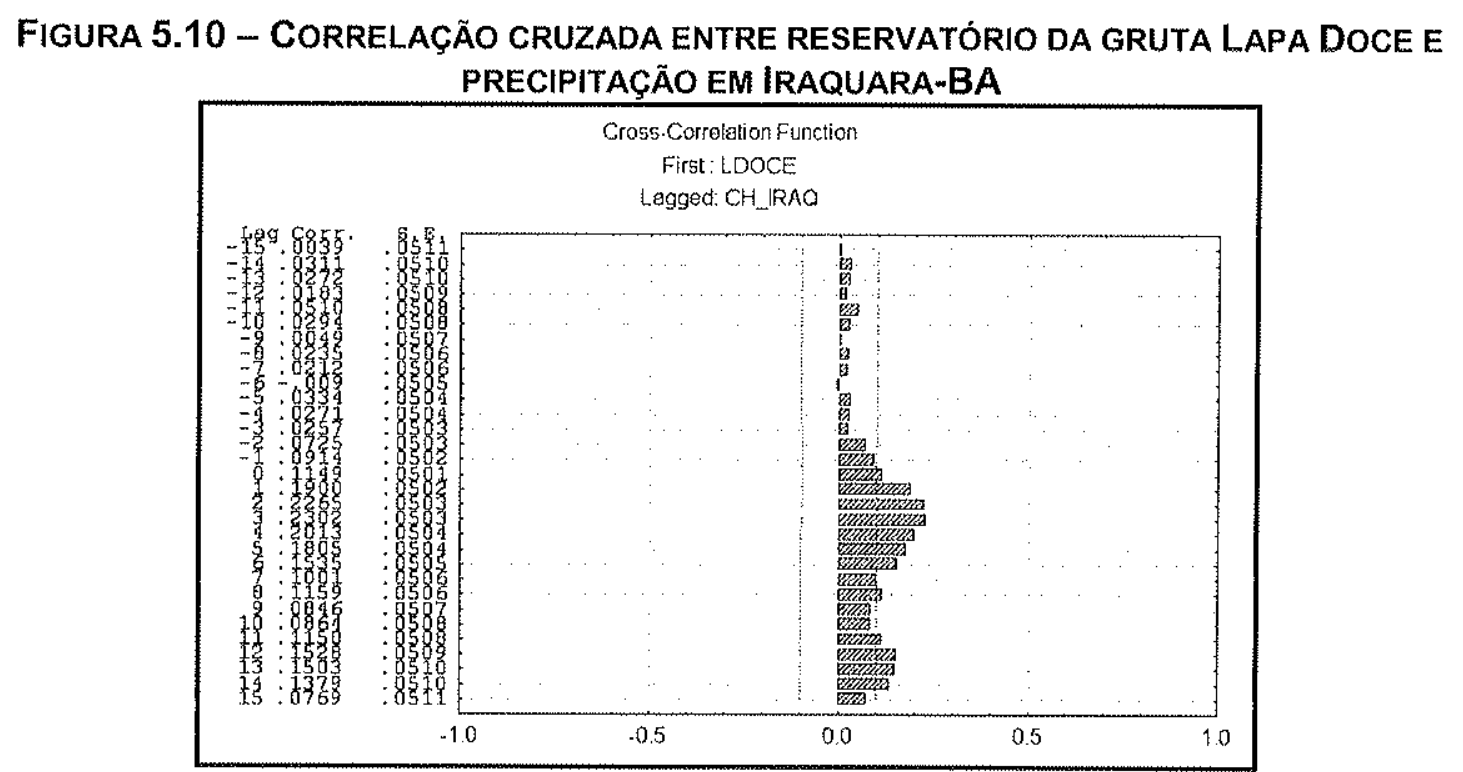


FIGURA 5.11- CORRELAÇÃo CRUZADA ENTRE SISTEMA GRUTA AZUL-PRATINHA E PRECIPITAÇÃo EM IRAQUARA-BA

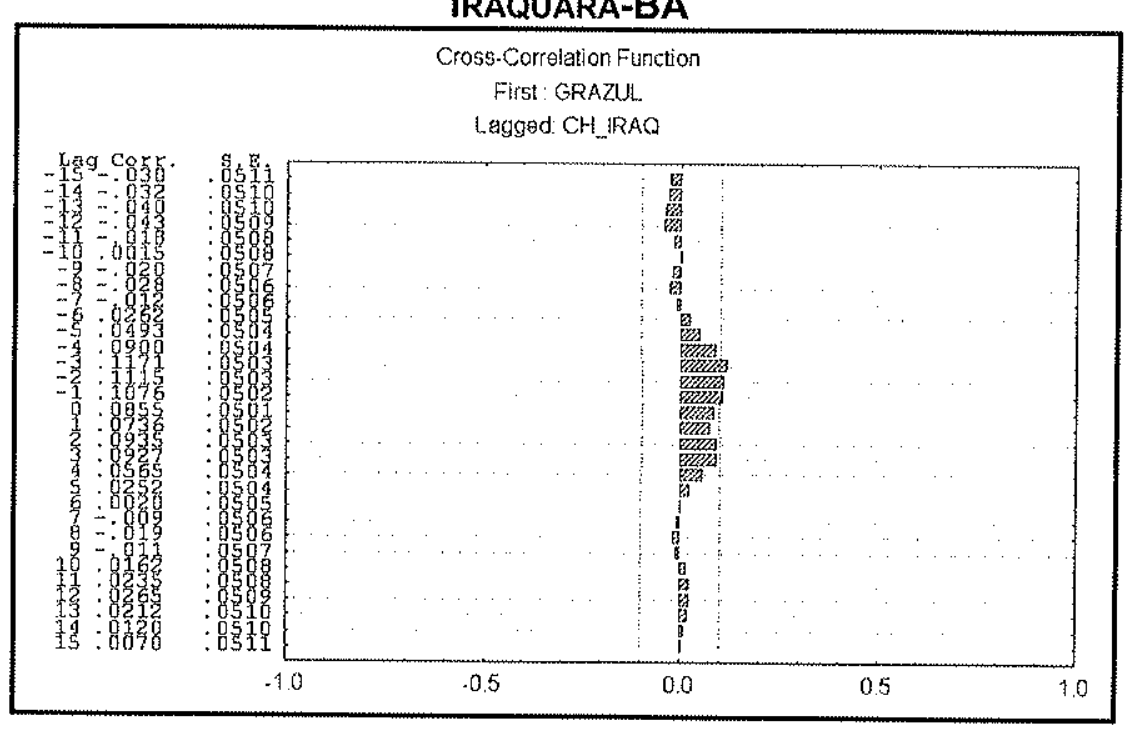

5.4.3 - Hidrologia da nascente do rio Pacuí

A vazão da nascente do rio Pacuí foi monitorada ao longo de 12 meses. Foram realizadas quatro medidas de vazão para este estudo, distribuídas em intervalos de tempo regulares, buscando acompanhar as variações das estações do ano.

As medidas de variação do nível d’água foram feitas mensalmente por um morador da localidade, que também registrou eventuais variações quando de eventos de chuvas. A curva-chave (figura 5.12) foi determinada a partir dos dados da tabela 5.3 e obteve-se a equação a seguir.

$$
\mathbf{Q}=0,0192 \mathbf{A}+1,06 \text { com } R^{2}=0,9166
$$

TABELA 5.3 - DAdOS BÁSICOS PARA CONSTRUÇÃo dA CURVA CHAVE PARA A NASCENTE do PACUÍ

\begin{tabular}{ccc}
\hline mês & altura da régua & $\mathbf{Q}\left(\mathbf{m}^{3} / \mathbf{s}\right)$ \\
\hline jul/02 & 72 & 0,308 \\
dez/02 & 74 & 0,371 \\
$\mathrm{mai} / 03$ & 70 & 0,289 \\
set/03 & 70 & 0,291 \\
\hline
\end{tabular}


Figura 5.12 - CuRVa Chave nascente do RIo Pacuí

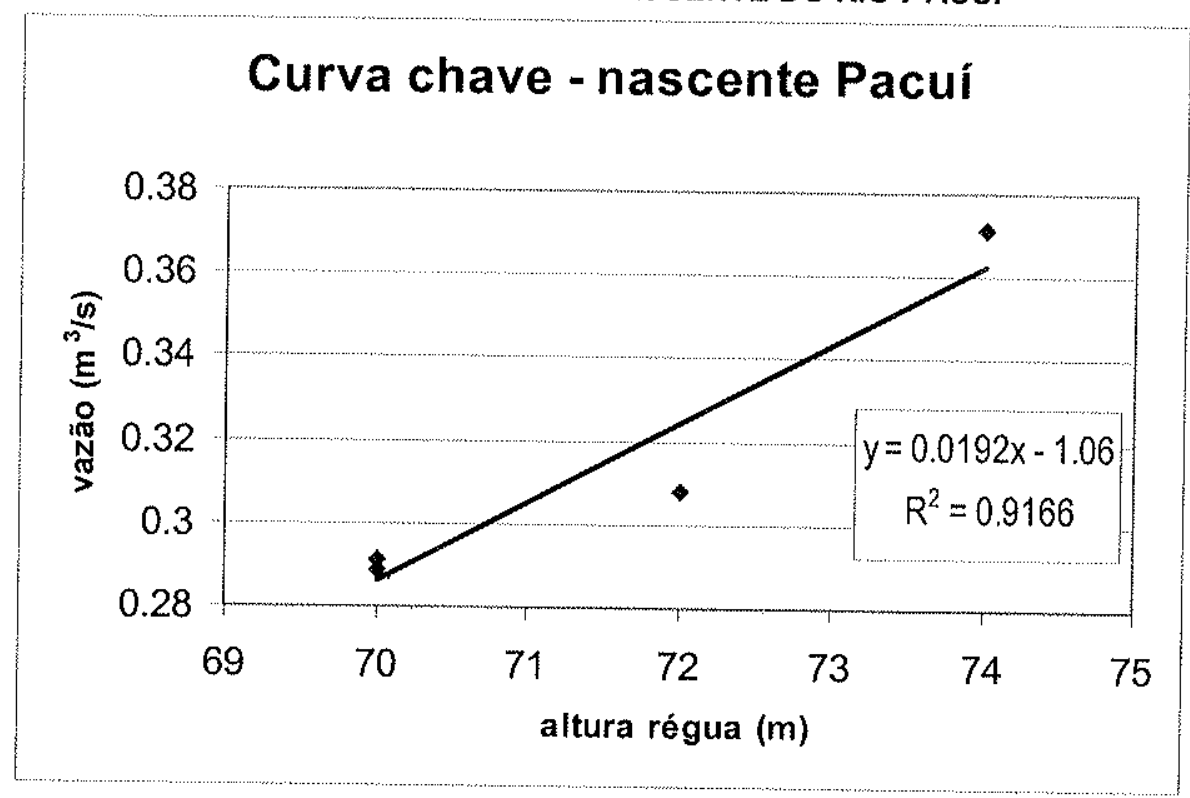

Com base na equação chave acima, transformou-se a curva de variação do nivel d'água versus tempo na curva vazão mensal em função do tempo (fluviograma, (figura 5.13). A tabela 5.4 a seguir mostra alguns parâmetros obtidos para a nascente do Pacui, tendo como base o fluviograma (figura 5.13), correspondente ao período de 03 de setembro de 2002 a 11 de setembro de 2003. De mesma forma que na Pratinha, os cálculos de vazões e volumes cálculos envolvem um erro de 15\% (Garcez, 1967). Ressalta-se que o fluviograma do rio Pacuí é diferente do da Nascente da Pratinha, pois refere-se a dados mensais e não diários.

Figura 5.13- FluviogRama da NASCENTE do PACUÍ

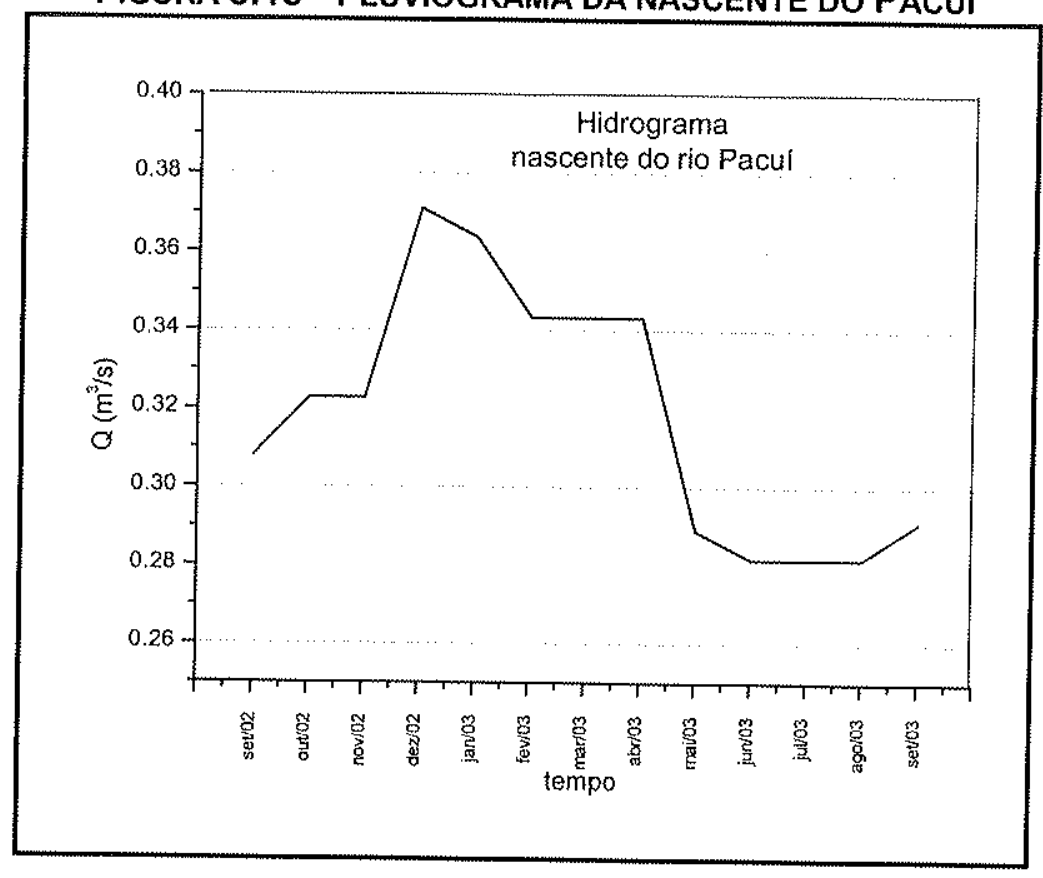


TABELA 5.4 - PARÂMETROS HIDROLÓGICOS DA NASCENTE do PACUÍ

\begin{tabular}{lcc} 
Vazão média & $\mathbf{Q}_{\operatorname{med}}$ & $0,319 \mathrm{~m}^{3} / \mathrm{s}$ \\
Vazão máxima & $\mathbf{Q}_{\max }$ & $0,371 \mathrm{~m}^{3} / \mathrm{s}$ \\
Vazão mínima & $\mathbf{Q}_{\min }$ & $0,282 \mathrm{~m}^{3} / \mathrm{s}$ \\
Razão entre $Q_{\max } / Q_{\min }$ & $\mathbf{Q}_{\max } / \mathbf{Q}_{\min }$ & $1,317 \mathrm{~m}^{3} / \mathrm{s}$ \\
\hline Volume total escoado (370 dias) & $\mathrm{Vt}$ & $9.561 .600 \mathrm{~m}^{3}$ \\
Volume de escoamento direto & $\mathrm{Vd}$ & $3.663 .360,00 \mathrm{~m}^{3}(38,3 \%)$ \\
Volume de escoamento básico & $\mathrm{Vb}$ & $5.898 .240 \mathrm{~m}^{3}(61,7 \%)$ \\
\hline
\end{tabular}

A classificação para esta nascente, através da razão $Q_{\max } / Q_{\min }$, é do tipo Fluxo Total Permanente (full flow), justificado pelo valor, $Q>0$ ao longo de todo ano. Nesta porção, representada pela região de Laje dos Negros, município de Campo Formoso$\mathrm{BA}$, em virtude da estiagem de água, da ausência de distribuição regular de poços na área e da inexistência de um controle correto das cotas de altitude dos parcos poços, não foi possivel estabelecer um mapa potenciométrico. No entanto, considerando as características geológicas, o entendimento dos corpos d'água dispostos em algumas poucas cavidades e, sobretudo, a razão $Q_{\max } / Q_{\min }$, pode-se inferir sobre a existência de um gradiente hidráulico subterrâneo convergente em direção à nascente do rio Pacuí, por esta ser a única nascente representativa e perene na região. Da mesma maneira que na bacia de Irecê, o ponto de recarga do aqüifero se dá através de precipitações nas serras metareníticas do Grupo Chapada Diamantina situadas à oeste da região.

A recarga dos aqüíferos situados nas rochas carbonáticas do Grupo Una foram investigadas também por Bastos \& Peixoto et al, (2004) que efetuaram um estudo da caracterização do fluxo da água subterrânea amparados pela aplicação de isótopos de $\mathrm{O}$ e $\mathrm{H}$. Definiram que na borda leste da bacia, em função dos baixos valores de concentração de isótopos pesados, as águas são mais recentes e sofreram menores ações do processo de evaporação. Concluíram ainda, em virtude das informações isotópicas das águas da Barragem de Mirorós (a oeste da bacia de Irecê, no planalto metarenítico) $\left(\delta^{18} \mathrm{O}=-1,4 \%\right.$ e $\delta \mathrm{D}=-17 \%$ ) que estas águas são distintas em relação ás águas coletadas em rio correlato a $100 \mathrm{~km}$ a jusante, com valores $\left(\delta^{18} \mathrm{O}=-3,9 \%\right.$ e $\delta \mathrm{D}=-$ 
23\%o) que indicam uma diferenciação isotópica não concordante ao esperado, se considerasse que ocorreria uma concentração em pesados em função da evaporação ao longo do trajeto do rio, admitindo que este seja suprido pelo reservatório de Mirorós. No entanto, em virtude da diferenciação, sugere-se que a anomalia é devida ao pequeno volume de água que é fornecido ao rio pela barragem em comparação com volumes mais expressivos de água subterrânea oriundos dos metarenitos do Grupo Chapada Diamantina.

\section{5 - Fluxo de massa do sistema estudado}

A resposta da variação dos niveis potenciométricos pela indução pluviométrica é um fator positivo para a espeleogênese do carste associado ao Grupo Una, pois permite a aeração e a reativação de rotas de fluxo confinadas.

A relação entre as informações do monitoramento hidroquímico da nascente da Pratinha e os dados de vazão do sistema, permite estimar a taxa de descarga para os principais ânions envolvidos. Observa-se que $\mathrm{OSO}_{4}{ }^{2-}$, ao longo do tempo de monitoramento, não sofre alterações significativas em suas concentrações, por outro lado o $\mathrm{HCO}_{3}{ }^{*}$ sim, porém com variação diferenciada (figura 5.14).

De um modo geral, as variações das concentrações dos ions no exutório do sistema em comparação com as obtidas para o aqüífero profundo, mostram que existe uma injeção de água alogênica, oriunda dos metarenitos, já que a recarga pluviométrica direta sob o sistema responde por apenas $2 \%$.

A variação de $\mathrm{HCO}_{3}{ }^{-}$pode ser explicada pelo fato de sua presença na água ser relacionada a fatores de sazonalidade climática, uma vez que maiores índices de recarga pluviométrica associadas a clima quente, favorecem a produção maior de $\mathrm{CO} 2$ no solo, o que por sua vez, incrementa a dissolução de rocha carbonática no epicarste. Já a constância das concentrações de $\mathrm{SO}_{4}{ }^{2 *}$ é vinculada ao fato que sua origem parte da oxidação da pirita (formação de ácido sulfúrico, que libera sulfato a partir da ação do referido ácido na rocha), em ambiente de fluxo freático profundo que necessariamente não sofre influência direta dos condicionantes climáticos.

O cálculo do fluxo de massa para a nascente da Pratinha, referente ao ín sulfato, totalizou cerca de 34.021 toneladas de $\mathrm{SO}_{4}{ }^{2-}$ liberadas no exutório do sistema por ano, que correspondem a aproximadamente 21.274 toneladas de sulfeto, contra 
cerca de 570.330 mil toneladas de $\mathrm{HCO}_{3}{ }^{-}$. Para obter a massa de sulfato liberada por ano, multiplicou-se a concentração média deste íon, para a nascente da Pratinha, pelo volume total escoado. Para a nascente do Pacuí, o cálculo do fluxo de massa, para o íon sulfato, totalizou 2451 toneladas no período estudado, que corresponde à cerca de 1531 toneladas de pirita.

A estimativa de reservas de sulfetos na bacia de Irecê é da ordem de 1.686 .000 toneladas (CBPM,1998).

FIGURA 5.14 - RELAÇÃo VAZÃo E PARÂMETROS HIDROQUÍMICOS NA RESURGÊNCIA DA PRATINHA

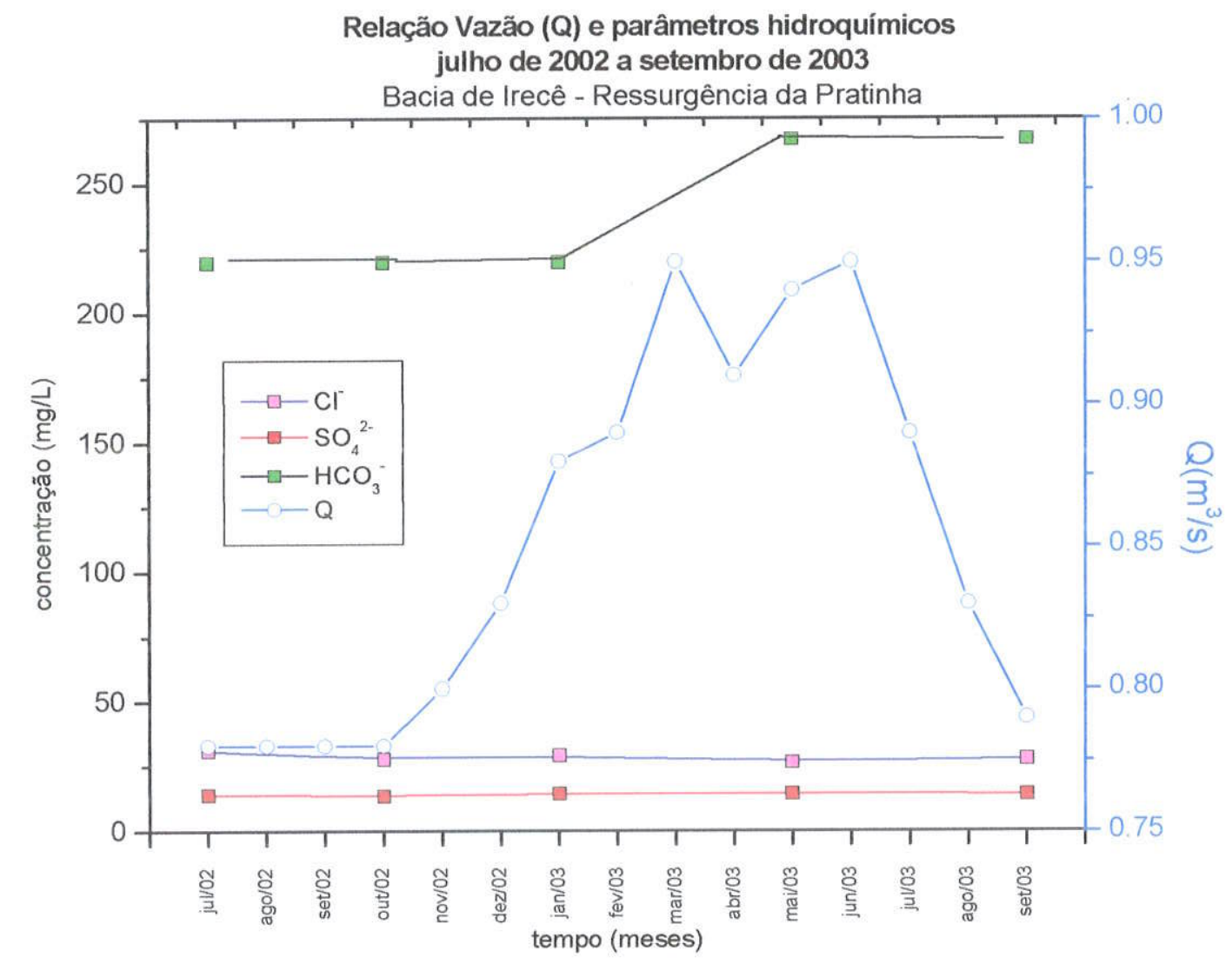




\section{CAPÍTULO 6 - ESPELEOTEMAS DE GIPSITA ASSOCIADOS AO CARSTE DO GRUPO UNA}

\section{1 - Introdução}

A evolução de um sistema cárstico, de um modo geral, pode ser dividida em duas etapas: uma primeira relacionada com a abertura e ampliação dos condutos, e uma segunda relacionada com o preenchimento sedimentar, incluindo sedimentos clásticos e químicos. Assim, os espeleotemas (do grego, spelaion - caverna e themas - depósito), são minerais secundários, resultado do processo de precipitação, evaporação, substituição, entre outros, de soluções que percolam no ambiente cárstico.

Como o objetivo do presente estudo é testar a participação do ácido sulfúrico no processo corrosivo associado ao desenvolvimento do carste, enfatizou-se os minerais secundários de sulfato, pois, conforme a literatura sobre o tema (Hill, 1995; Worthington, 1991), a presença destes em grande quantidade é um fator diagnóstico da provável ação de $\mathrm{H}_{2} \mathrm{SO}_{4}$ no sistema.

$\mathrm{Na}$ região de estudo, em função das cavernas serem formadas em rochas carbonáticas da Formação Salitre, os espeleotemas mais freqüentes são os formados pelo mineral calcita, predominantemente representados na forma de estalactites e estalagmites, contudo, cabe ressaltar que é também expressiva a ocorrência de espeleotemas em sulfato.

A deposição de minerais de sulfato em cavernas não é tão bem entendida como é a dos minerais carbonáticos, principalmente devido a maior complexidade e variedade de processos envolvidos. Na maioria dos casos, o transporte de sulfato em solução ocorre diretamente de sua fonte para locais secos de uma cavidade, onde a evaporação causa a precipitação(Hill \& Forti, 1997). Em outros casos, a corrosão com substituição pode ser o processo deposicional do sulfato ao invés da evaporação.

A oxidação de sulfeto é a fonte mais comum de sulfato para minerais em caverna. Pirita $\left(\mathrm{FeS}_{2}\right)$, ou outros sulfetos, são oxidados e formam ácido sulfúrico; este ácido ataca a rocha carbonática, enriquecendo as soluções resultantes com sulfato de cálcio, que é transportado em solução nos condutos cársticos. Perna e Pozzi (1959), Jude (1972), Sultanov (1975), Bertolani et al. (1976), Calandri $(1979,1980)$, e Onac (1991) estão entre os muitos pesquisadores que atribuíram a gênese de minerais de 
sulfato em cavernas à oxidação de pirita ou corpos de minério de sulfeto.

Os principais mecanismos responsáveis pela formação de minerais de sulfato, segundo Hill \& Forti (1997) são:

a- Precipitação simples por evaporação. Neste processo, os espeleotemas de sulfato podem ser depositados por água capilar que flui lentamente pelos poros da rocha, em direção a partes secas do sistema, em função de um gradiente de evaporação na zona de parede.

b- Substituição por dissolução. Este processo, proposto por Pohl e White (1965) envolve a oxidação de minerais de sulfeto ou sulfeto de hidrogênio $\left(\mathrm{H}_{2} \mathrm{~S}\right)$ com a formação de ácido sulfúrico. Este ácido sulfúrico reage então com a rocha carbonática para formar principalmente $\mathrm{CaSO}_{4}$, segunda a reação (r. 6.1).

$$
\mathrm{H}_{2} \mathrm{SO}_{4}+\mathrm{CaCO}_{3}+\mathrm{H}_{2} \mathrm{O} \leftrightarrow \mathrm{CaSO}_{4} \cdot 2 \mathrm{H}_{2} \mathrm{O}+\mathrm{CO}_{2}
$$

A precipitação de $\mathrm{CaSO}_{4}$ pode ocorrer no local da reação quando existe condições do $\mathrm{CO}_{2}$ ser liberado (Hill \& Forti, 1997). Esta etapa caracteriza a substituição do carbonato pelo sulfato. A liberação de $\mathrm{CO}_{2}$ ocorre predominantemente quando a solução atinge vazios, como por exemplo, paredes de cavernas em ambiente vadoso, produzindo crostas.

Por outro lado, se a mesma reação ocorrer em um local onde não há condições de liberação de $\mathrm{CO}_{2}$, (por exemplo, alguns ambientes freáticos profundos) o acúmulo do gás não permitirá que a reação se complete e, desta forma, o $\mathrm{CaSO}_{4}$ não deposita, pois a solução não atinge o produto de solubilidade, e há ainda uma sobra de $\mathrm{H}_{2} \mathrm{SO}_{4}$ na solução. A solução, nestas condições, ao percolar no aqüífero, pode encontrar vazios permitindo que o $\mathrm{CO}_{2}$ seja liberado e, conseqüentemente o $\mathrm{CaSO}_{4}$ depositado, completando assim a reação.

\section{2 - Ocorrências de gipsita no ambiente cárstico estudado}

A identificação dos espeleotemas de gipsita foi realizada sob duas formas: expedita (hábito e teste com $\mathrm{HCl}$ ) com observações diretas no campo, e por difratometria de Raio X, no laboratório de Mineralogia do IGc/USP.

Foram caracterizadas as seguintes formas de ocorrência: 


\section{a) gipsita acicular (agulhas)}

Este tipo de ocorrência caracteriza-se por agrupamentos de cristais de gipsita com hábito acicular, incolores e transparentes, encontrados freqüentemente no topo de sedimentos clásticos que apresentam gretas de contração (foto 6.1). As ocorrências na gruta Torrinha (Iraquara-BA) estão distribuídas em extensas áreas da cavidade. Nas bordas mais elevadas das pilhas de sedimentos clásticos ocorrem os maiores cristais, com comprimentos de até $30 \mathrm{~cm}$ e diâmetro de cerca de $2 \mathrm{~mm}$ (foto 6.2). Nas grutas Toca da Boa Vista e Toca da Barriguda (Campo Formoso-BA) este tipo de ocorrência forma concentrações em depressões nos sedimentos argilosos.

No contexto das cavernas do Brasil, as ocorrências deste tipo de depósito de gipsita são as únicas conhecidas até o momento.

\section{b) crostas de gipsita}

Depósitos de gipsita na forma de crostas ocorrem recobrindo a rocha carbonática em paredes e tetos de condutos, assim como blocos abatidos e outros espeleotemas. As crostas observadas apresentam espessuras que variam desde submilimétricas até milimétricas $(5 \mathrm{~mm})$. Os hábitos mais freqüentes da gipsita observados nestas crostas são o fibroso e cristalino. O primeiro caracteriza-se por um agrupamento de fibras de dimensões submilimétricas, que a tornam facilmente desagregável. Já o segundo hábito caracteriza-se pela presença de cristais achatados tabulares com faces milimétricas a centimétricas, que proporcionam um brilho vitreo característico. As crostas possuem coloração que varia de branco a marrom claro (bege), incluindo ocorrências onde são incolores.

Entre as cavernas pesquisadas, a gruta Didi apresenta o maior volume de crostas. Nesta observou-se blocos abatidos, com aproximadamente 6 metros de altura, completamente cobertos por crosta de gipsita, ressaltando-se que as mesmas recobrem determinados blocos em sua totalidade (foto 6.3). Observou-se também grandes espeleotemas recobertos por crosta de gipsita, inclusive em suas reentrâncias. Ressalta-se que as superfícies dos espeleotemas recobertos apresentam-se corroídas. Observam-se também feições de corrosão, do tipo pendants, tanto na rocha carbonática como em espeleotemas, cobertas por crostas de gipsita. (foto 6.4). $\mathrm{Na}$ gruta Torrinha observam-se crostas recobrindo paredes e tetos, porém, destaca-se um 
gruta Torrinha observam-se crostas recobrindo paredes e tetos, porém, destaca-se um setor onde testemunhos de sedimentos recobrem a crosta (foto 6.5). Junto a este depósito também há gipsita na forma fibrosa. Ocorrências análogas às descritas acima foram observadas em outras grutas da região de estudo. Na gruta Torrinha observamse também crostas com o hábito cristalino, recobrindo a integridade de alguns condutos. Estas são incolores porém, nas paredes da caverna onde se encontram, aparentam ser negras ou cinza-escuras, pois, devido sua transparência assumem a cor da rocha. Em outro setor desta gruta, observou-se crostas com hábito cristalino, porém, com cristais menores (milimétricos) que a anteriormente descrita. Também se diferencia das anteriores por demonstrar uma morfologia de manchas irregulares tendendo a um hábito arborescente no sentido do teto do conduto (foto 6.6).

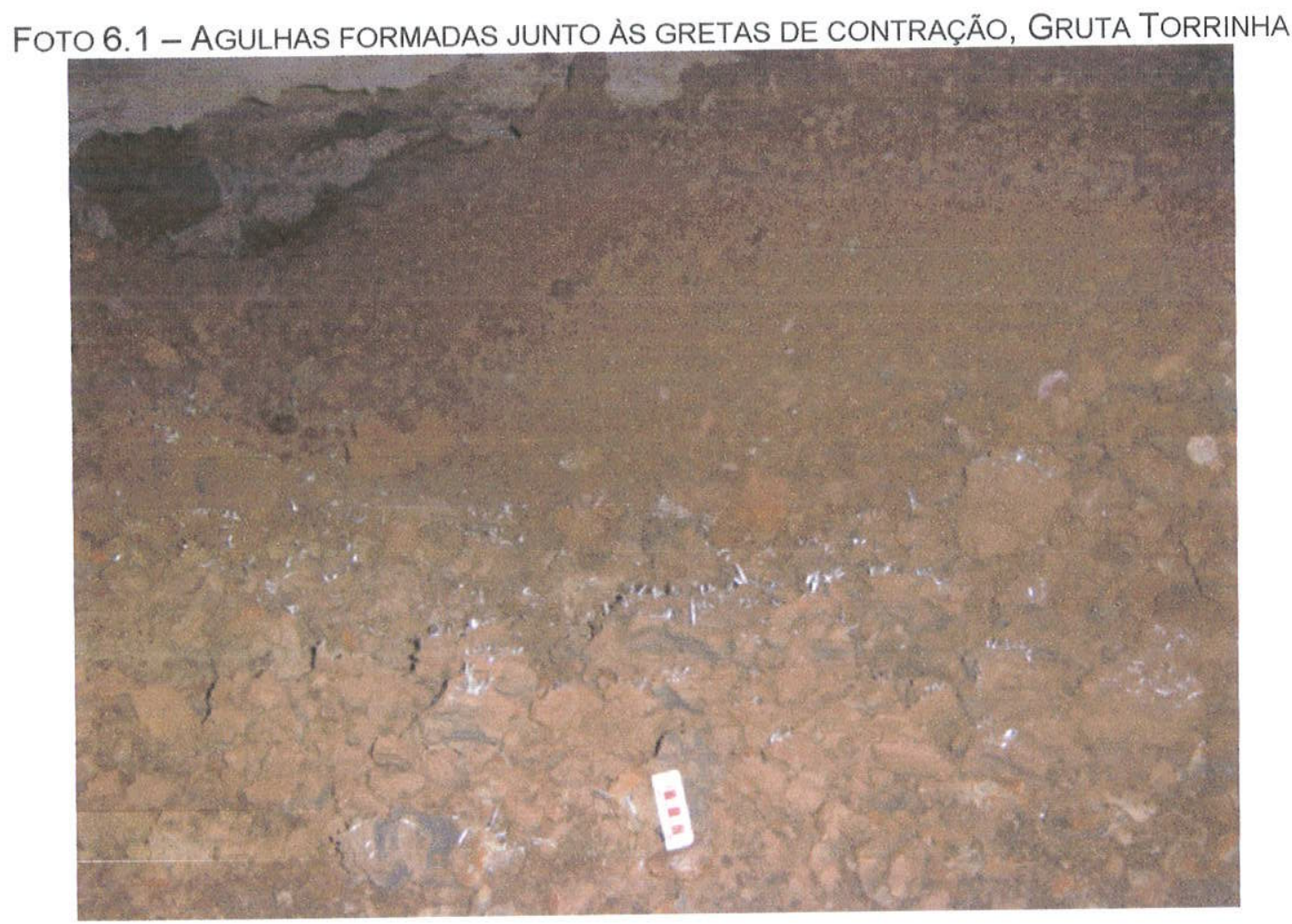


FOTO 6.2 - AGULHAS DE GIPSITA SOBRE SEDIMENTOS CLÁSTICOS, GRUTA TORRINHA

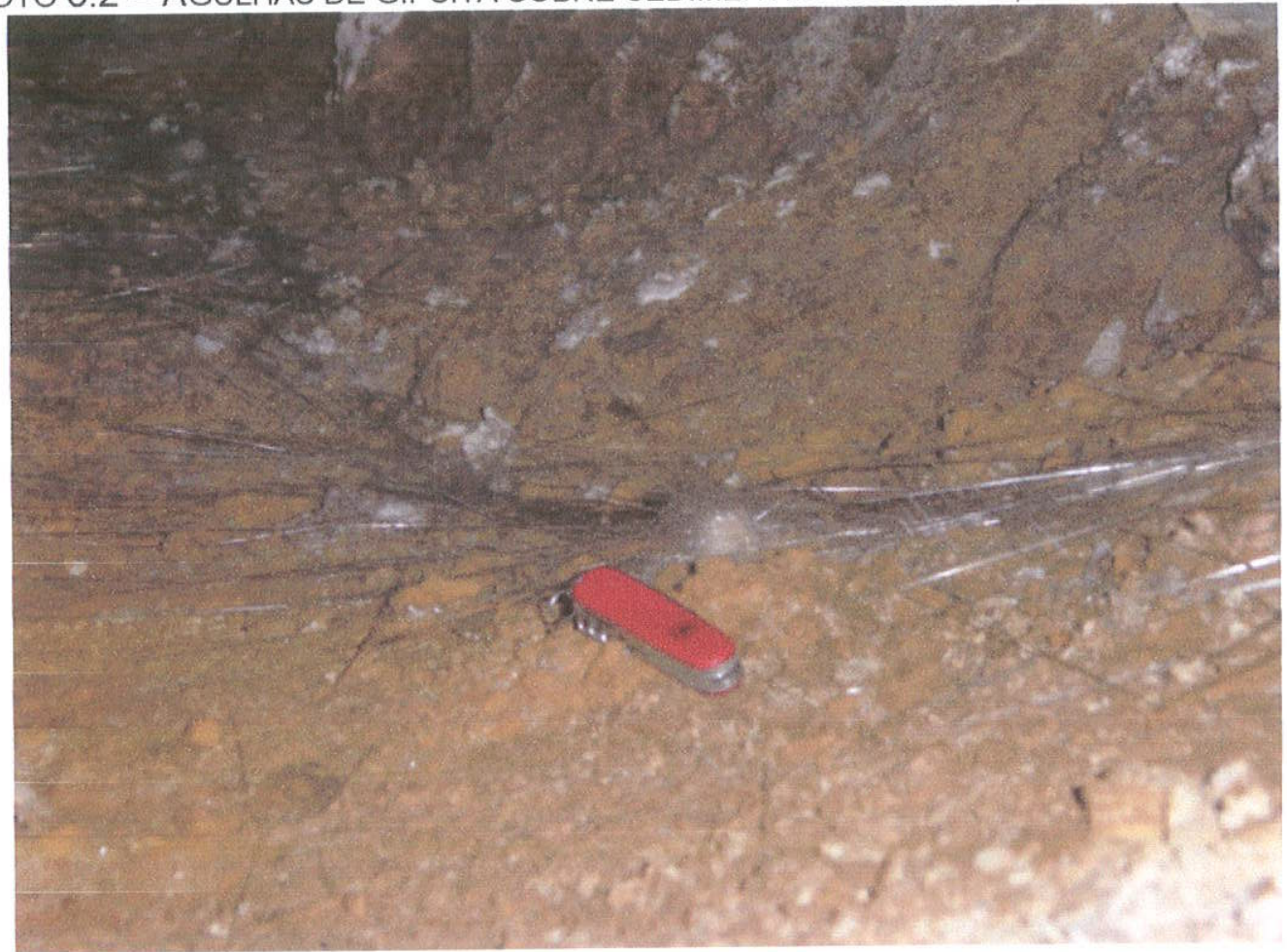

FOTO 6.4 - FEIÇÕES DE CORROSÄO NA ROCHA (PENDANTS) RECOBERTOS POR CROSTA DE GIPSITA

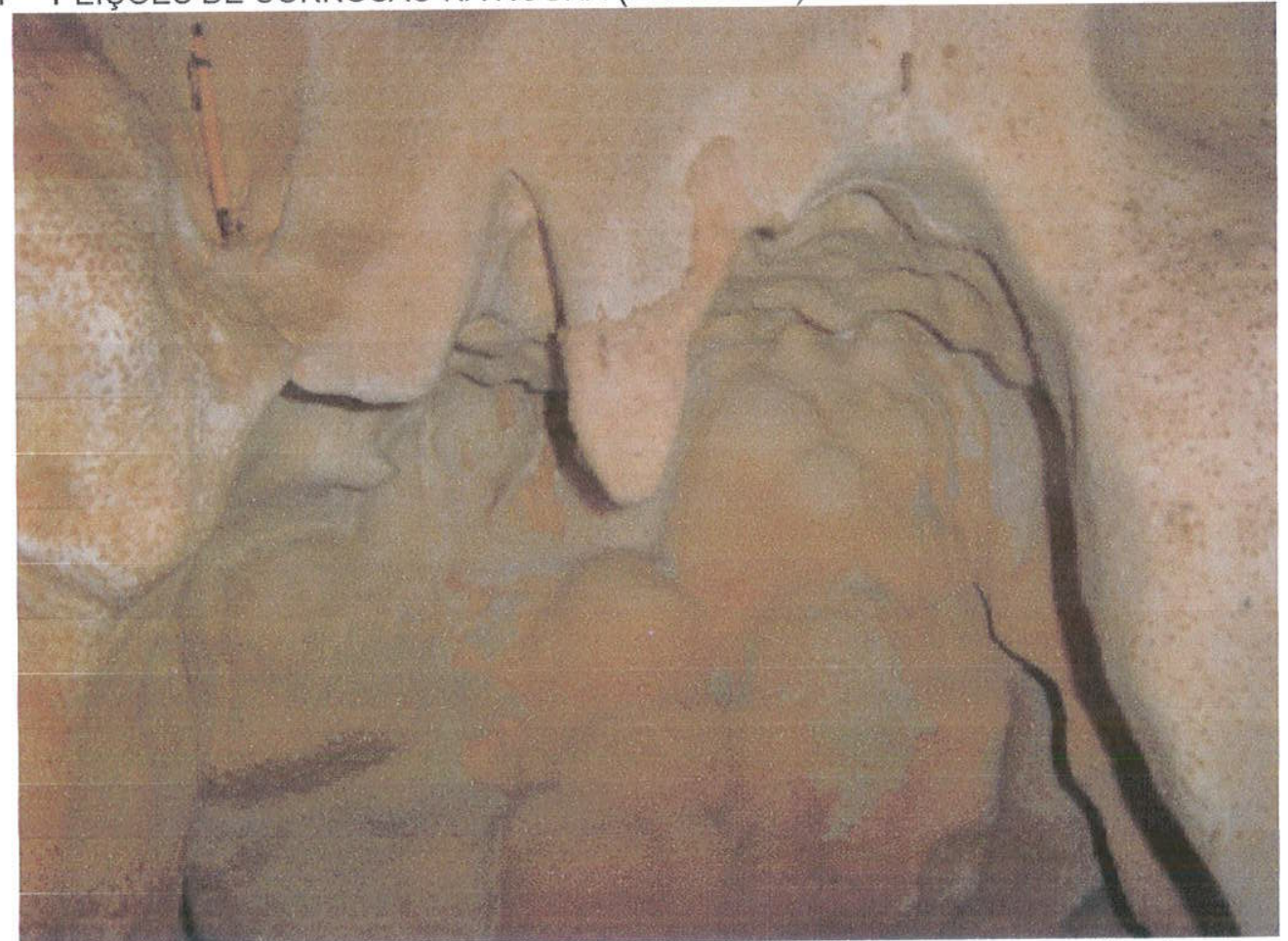

nota: na parte inferior da foto as manchas avermelhadas correspondem a testemunhos de sedimentos clásticos sobre a crosta 
FOTO 6.3 - BLOCOS ABATIDOS E ESPELEOTEMAS CARBONÁTICOS RECOBERTOS POR CROSTA DE GIPSITA

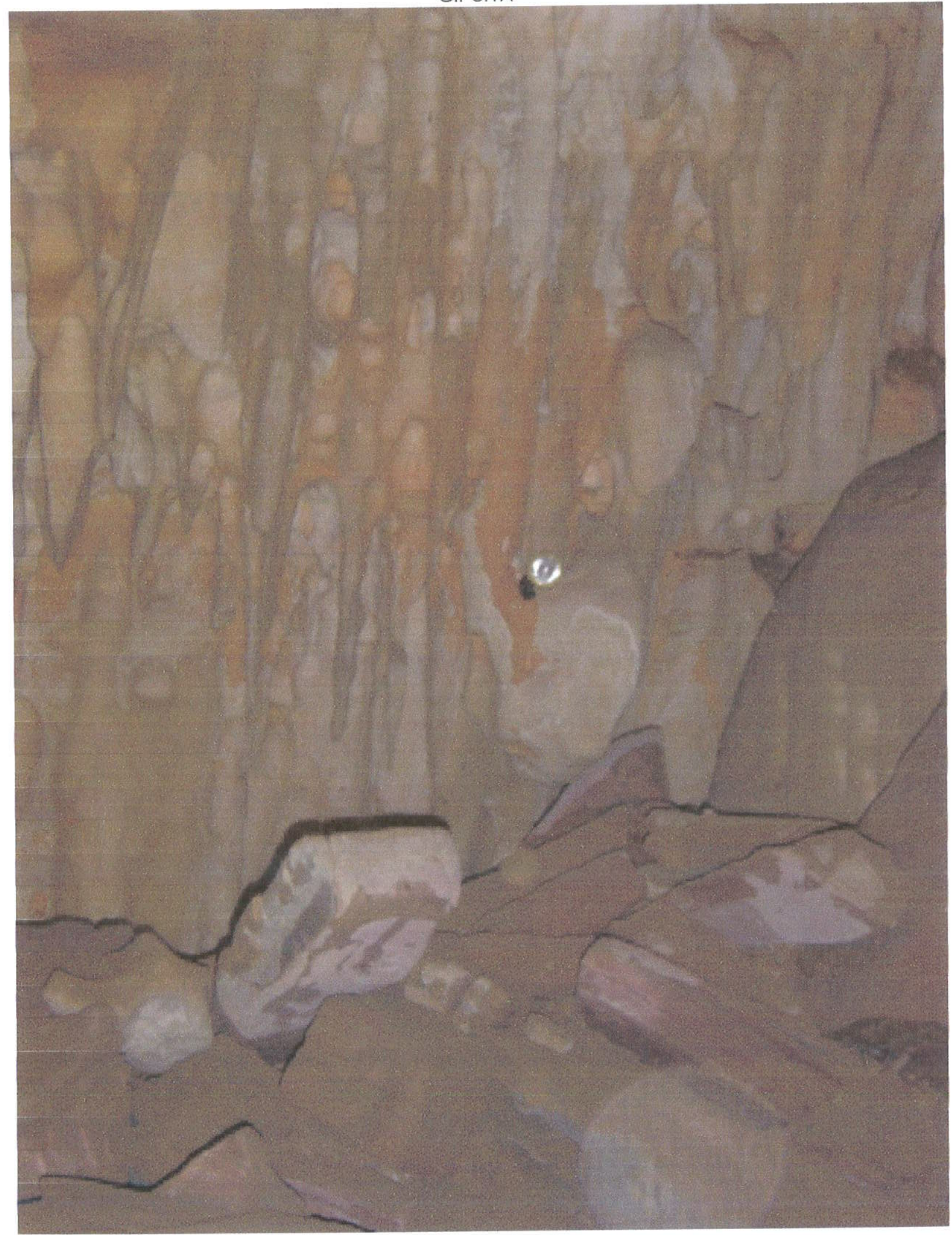

nota: no centro da foto uma lanterna como escala (diâmetro $10 \mathrm{~cm}$ ) 
FOTO 6.5 - SEDIMENTOS CLÁSTICOS SOBREPOSTOS A CROSTA DE GIPSITA

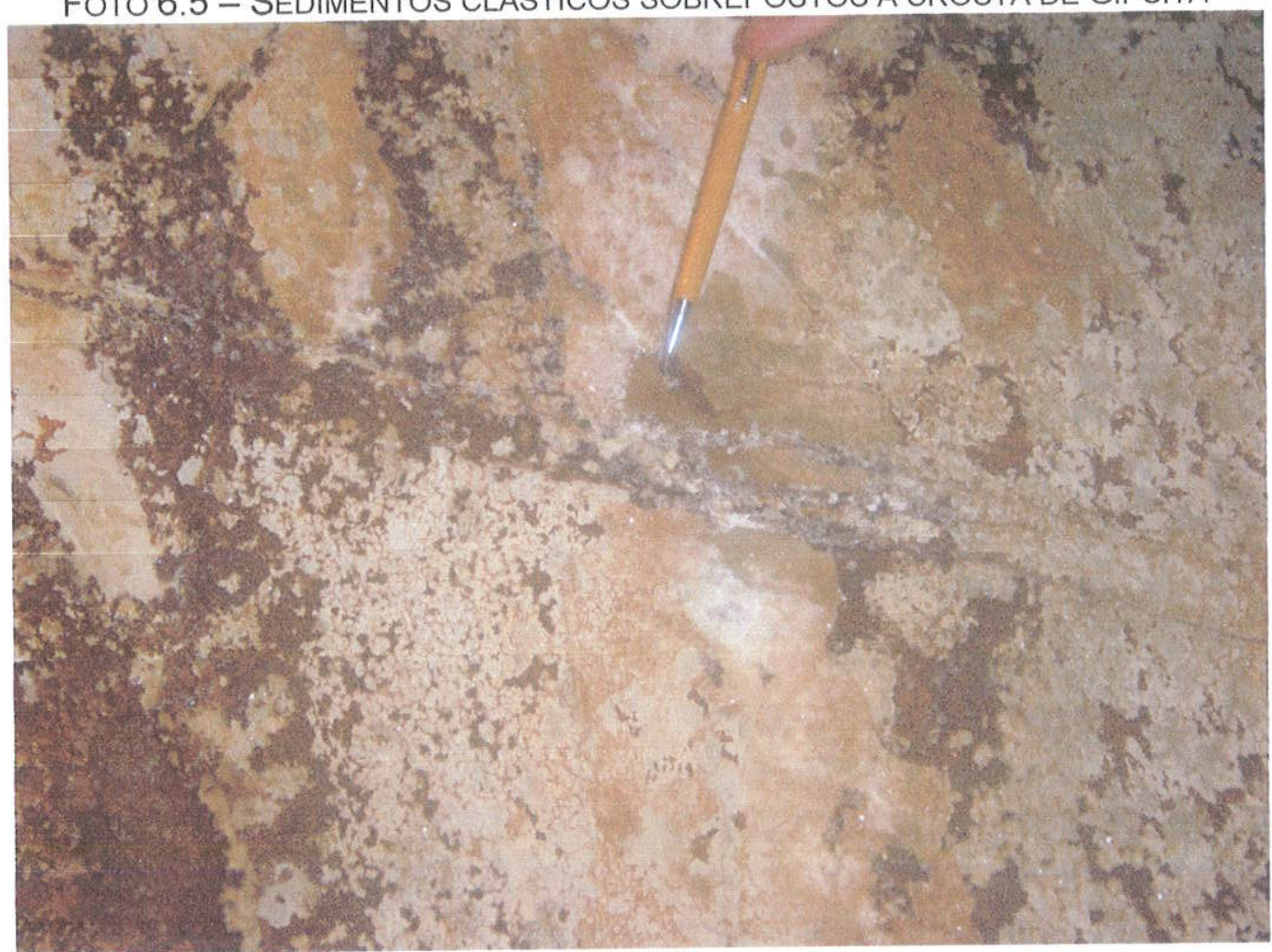

FOTO 6.6 - CROSTA DE GIPSITA CRISTALINA COM CRISTAIS MILIMÉTRICOS EM MANCHAS IRREGULARES, GRUTA TORRINHA.

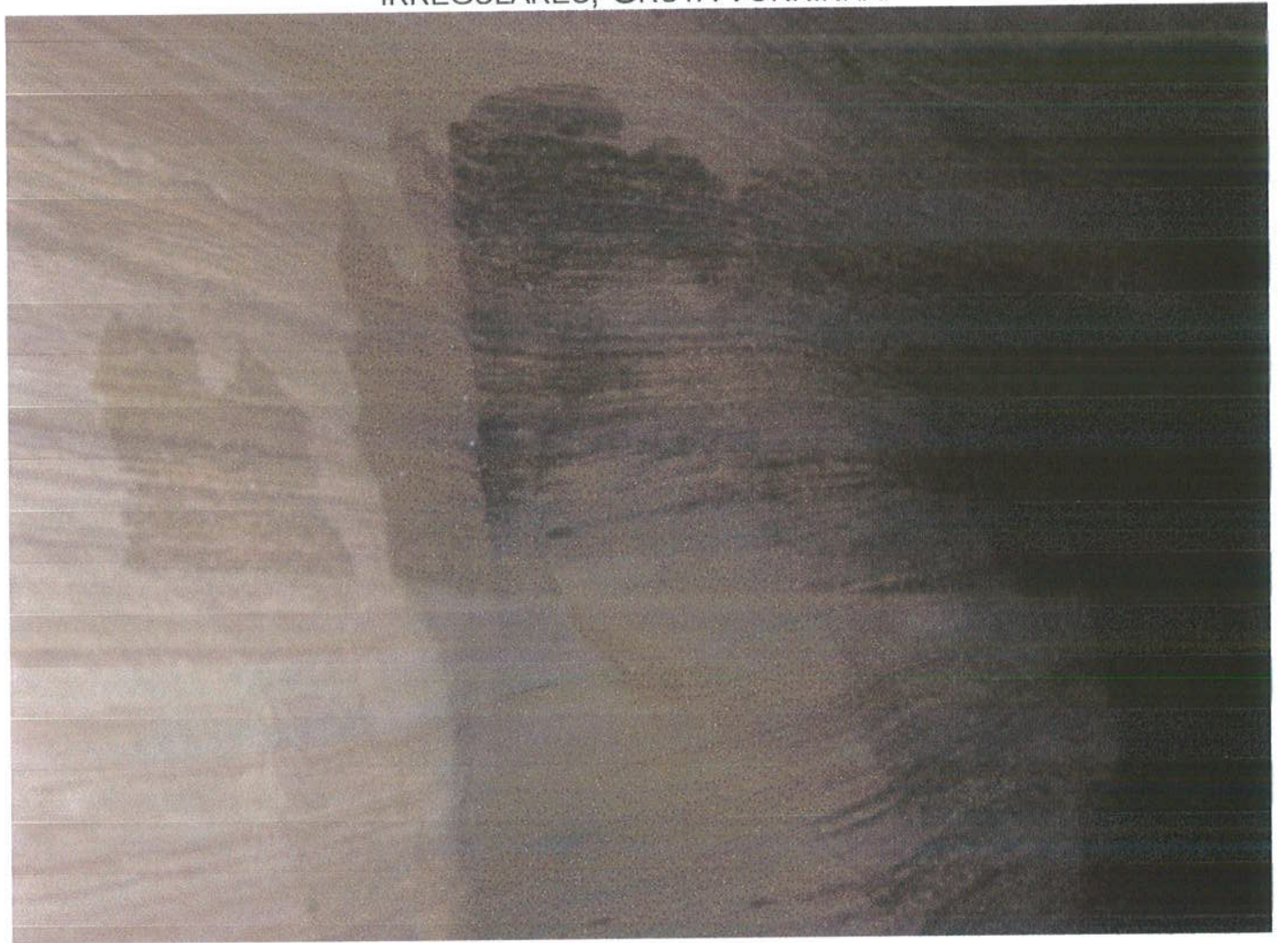

Nota: observa-se uma marca horizontal que corresponde a um antigo nivel d'água 


\section{c) gipsita fibrosa}

Este tipo de gipsita caracteriza-se por feixes milimétricos de fibras paralelas e retorcidas. Encontram-se mais freqüentemente nas paredes de condutos, onde acompanham preferencialmente juntas de estratificação da rocha carbonática como também, associadas a fraturas de aberturas submilimétricas. De forma menos freqüente pequenos tufos de gipsita fibrosa ocorrem também, associadas à gretas de contração, no topo de pilhas de sedimentos clásticos. (foto 6.7)

\section{d) estalactites}

Estalactites formadas por $\mathrm{CaSO}_{4}$ ocorrem na extremidade de estalactites originalmente de $\mathrm{CaCO}_{3}$. Possuem hábito cristalino, exibindo cristais euhedrais de dimensões centimétricas $(5 \mathrm{~cm}$ ). São predominantemente incolores, ocorrendo também em tons de branco. Na gruta Torrinha observou-se que as estalactites de $\mathrm{CaCO}_{3}$ que suportam a ponta de $\mathrm{CaSO}_{4}$, encontram-se corroídas. As pontas de $\mathrm{CaSO}_{4}$ encontramse em fase de crescimento (fotos 6.8 e 6.9). Na Toca da Barriguda foram observados conjuntos de estalactite e estalagmite cujas extremidades são de $\mathrm{CaSO}_{4}$.

FOTO 6.7 - GIPSITA FIBROSA ASSOCIADA A JUNTAS DE ESTRATIFICAÇÃO E CROSTAS DE GIPSITA NA PAREDE.

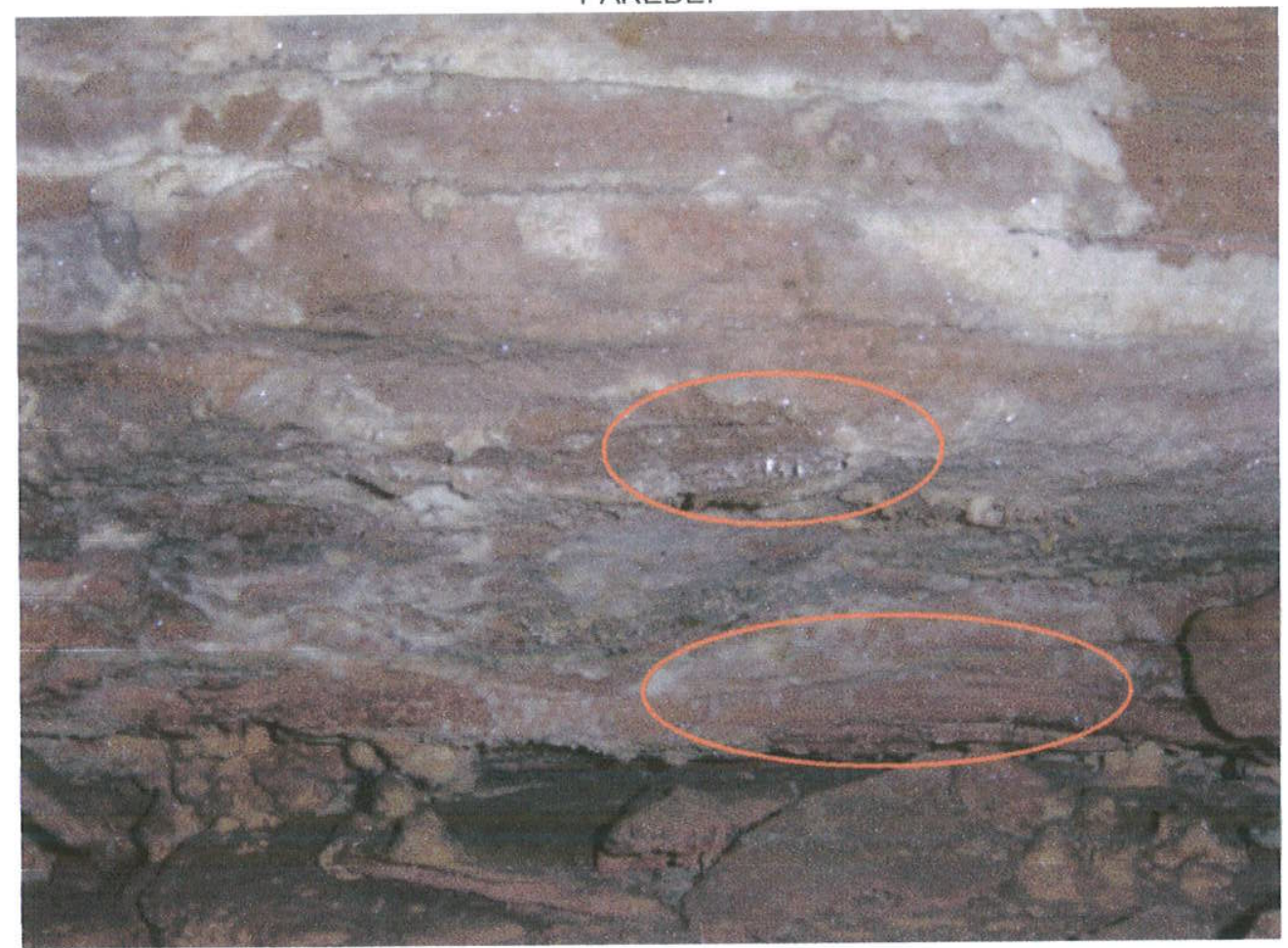


FOTO 6.8 -ESTALACTITE DE GIPSITA NA EXTREMIDADE DE ESTALACTITES CARBONÁTICAS

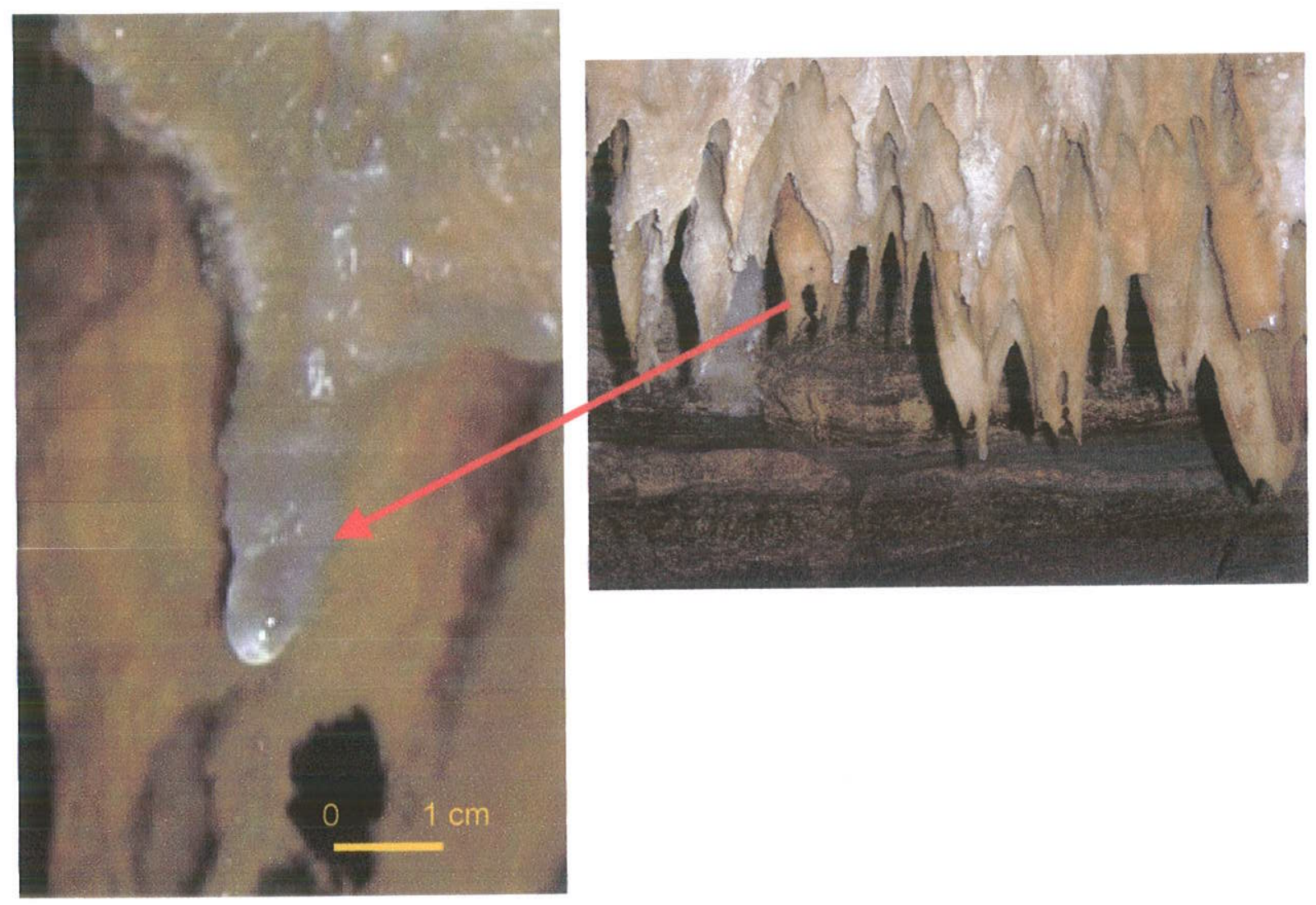

FOTO 6.9 - CONJUNTO DE ESPELEOTEMAS CARBONÁTICOS (TIPO CORTINA) COM FEIÇÕES DE CORROSÃO E DEPOSIÇÃO DE GIPSITA NA FORMA DE ESTALACTITES E CROSTAS

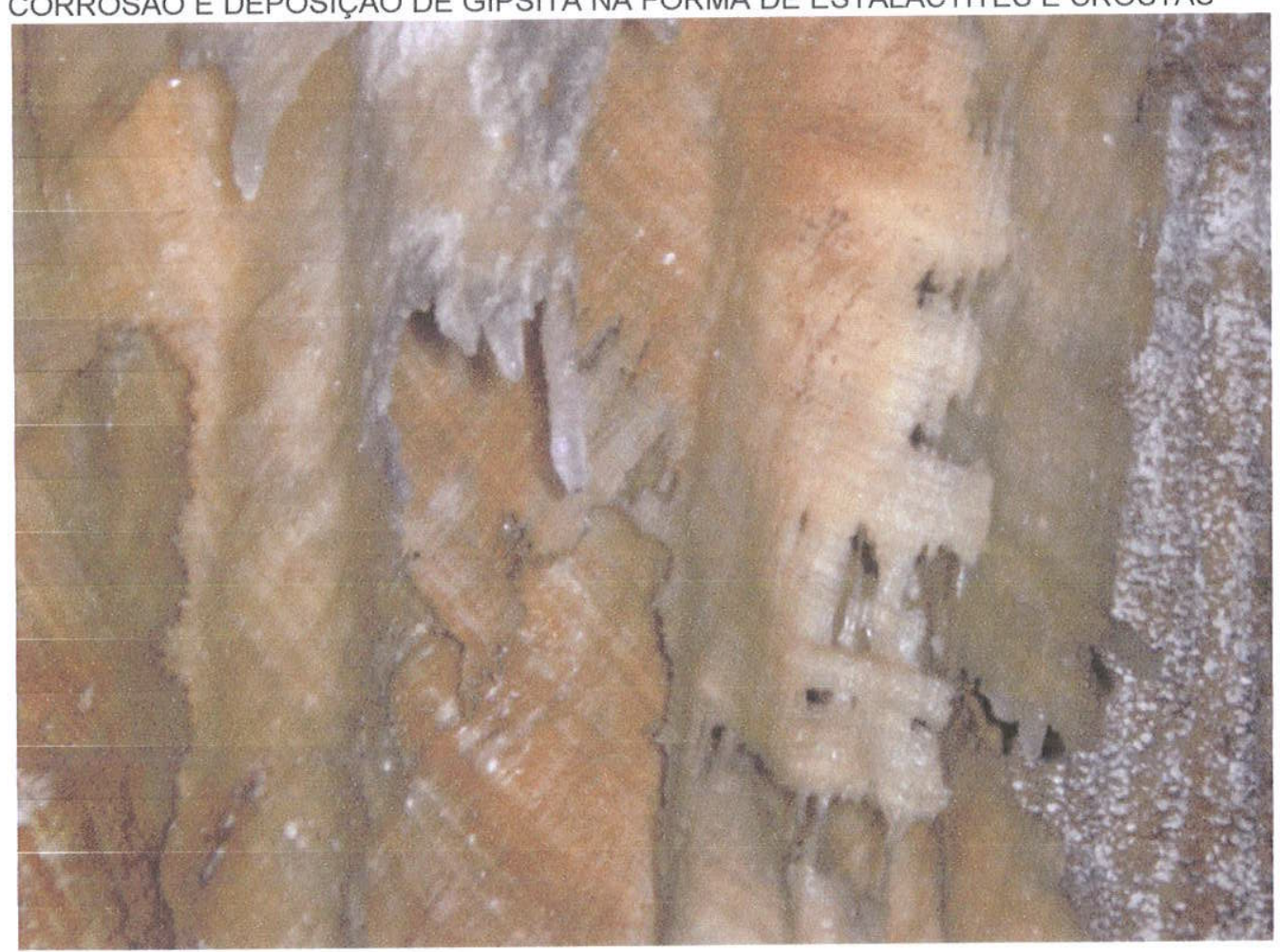




\section{e) Filamentos de gipsita}

Este tipo de ocorrência de gipsita é constituído por um conjunto de filamentos de espessura submilimétrica e comprimento centimétrico, que caracterizam-se pelo entrelaçamento de fios, independentes, que formam aglomerados dispostos na parede. Na gruta Torrinha observou-se que estes depósitos estão limitados na porção inferior por uma marca de nível d’água. (foto 6.10)

\section{f) gipsita maciça e tabular}

Este tipo de ocorrência de gipsita é caracterizada por estruturas tabulares, com espessura submilimétrica a centimétrica, dispostas preferencialmente entre os planos de estratificação da rocha carbonática e superfícies de deposição de espeleotemas como escorrimentos calcíticos. O hábito predominante é o fibroso, com cristais perpendiculares ao plano de crescimento. A distribuição deste tipo de ocorrência é generalizada nas cavernas pesquisadas na região de Iraquara, estando sempre associadas a feições de ruptura da rocha carbonática e desplacamento desta em função da expansão que ocorre durante a cristalização de $\mathrm{CaSO}_{4}$. A ocorrência é evidenciada pelo acúmulo de lascas e blocos no piso logo abaixo das paredes e tetos alterados (fotos $6.11,6.12$ e 6.13 ).

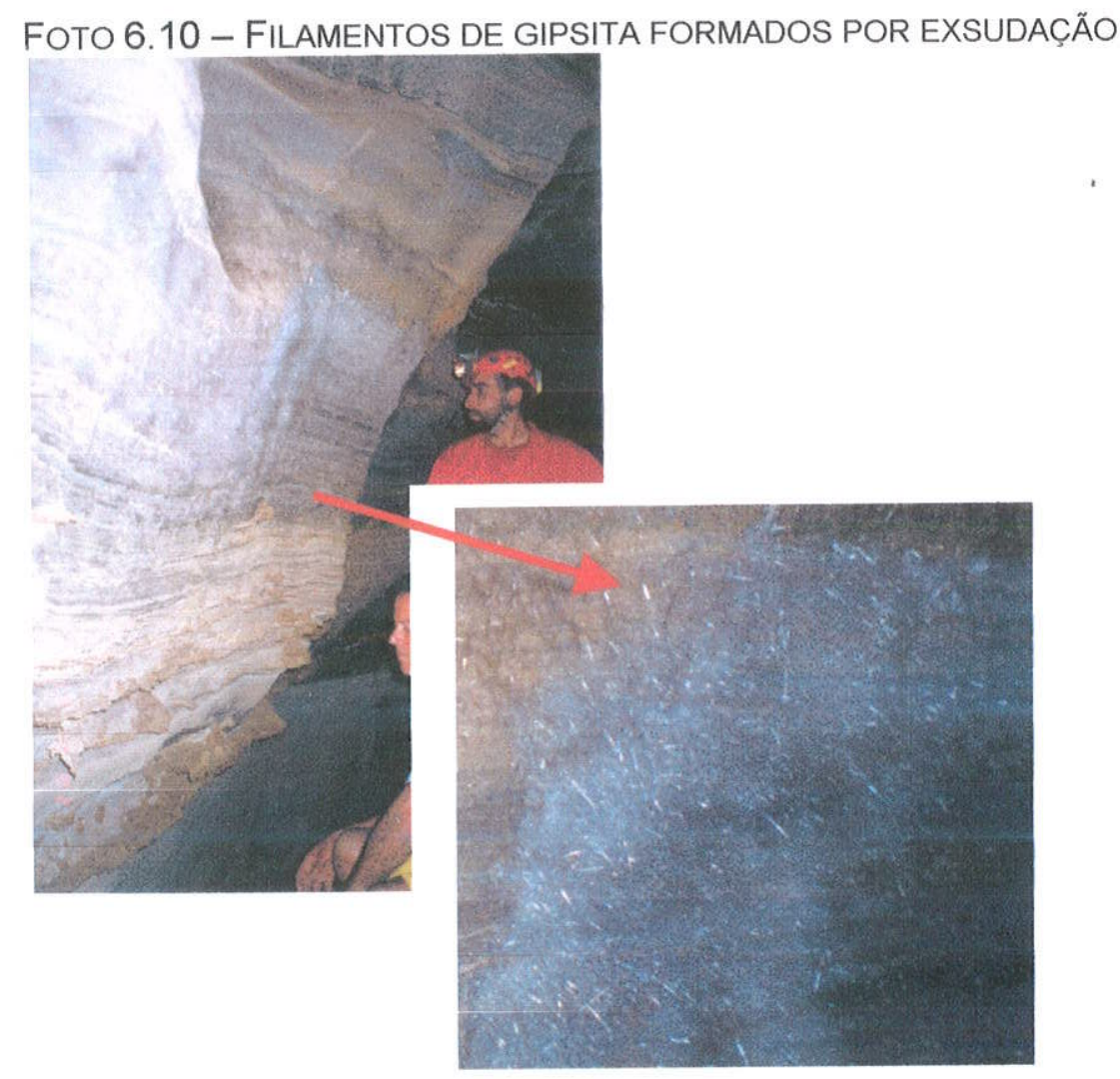


FOTO 6.11 - DESPLACAMENTO DE TETO POR EXPANSÃO DE CRESCIMENTO DE GIPSITA NA GRUTA DIDI. NO PISO OBSERVAM AS LASCAS E BLOCOS ORIUNDOS DO TETO

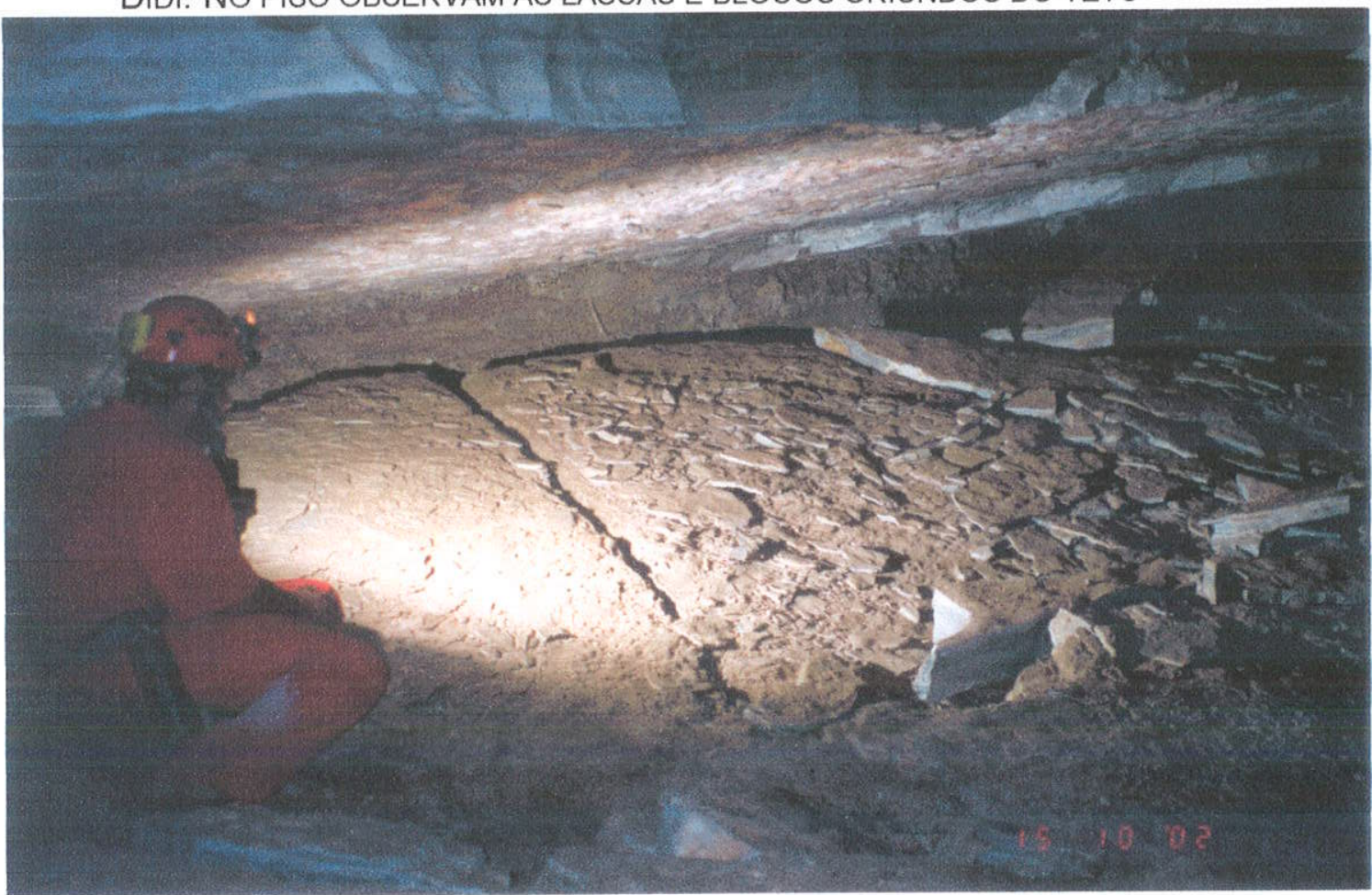

FOTO 6.12 - DESPLACAMENTO DE PAREDE POR EXPANSÃO DE CRESCIMENTO DE GIPSITA EM PLANOS DE ESTRATIFICAÇÃO DA ROCHA NA GRUTA SANTA MARTA. NOTA-SE O ACÚMULO DAS LASCAS DE ROCHA CARBONÁTICA JUNTO À PAREDE ALTERADA

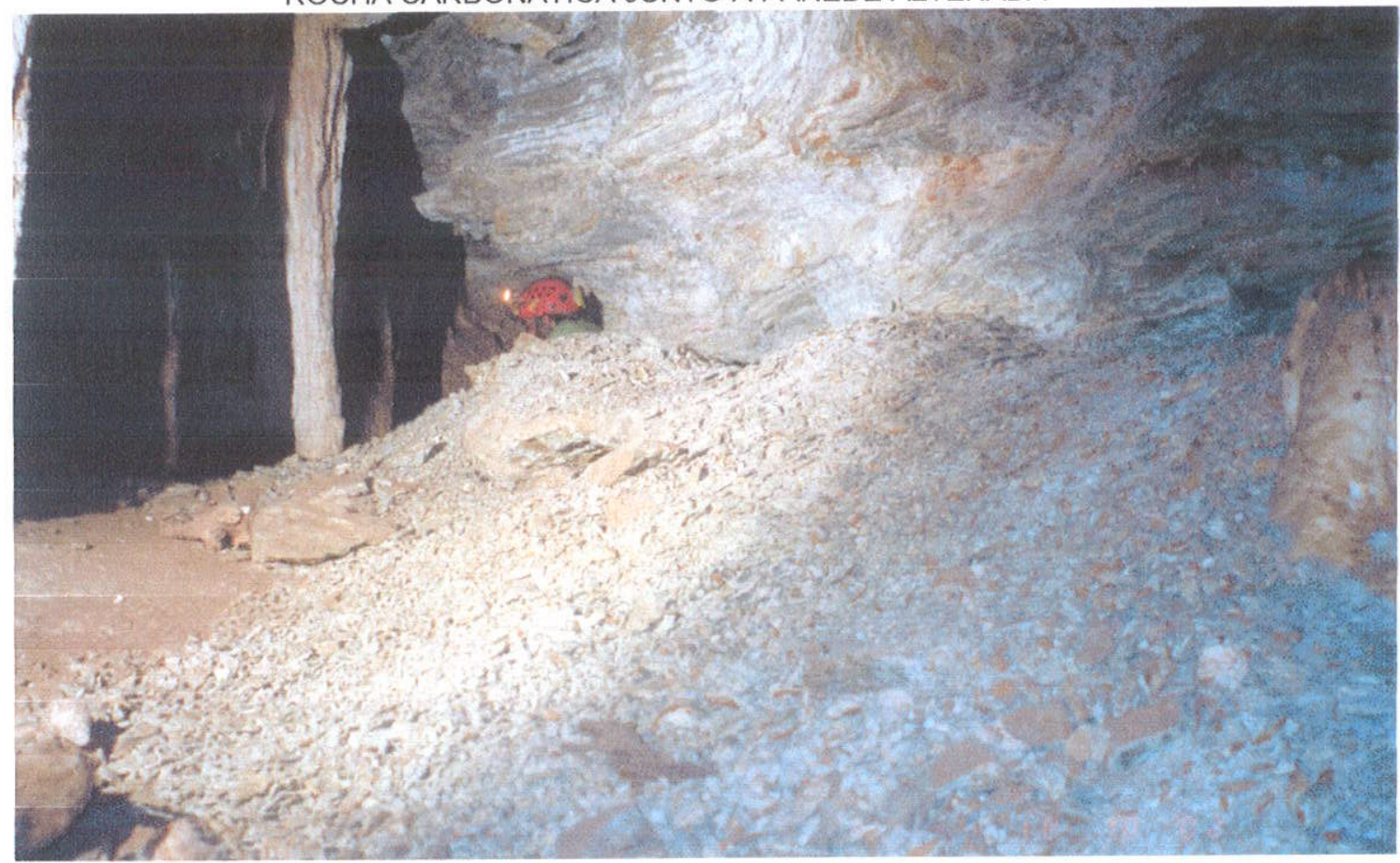


FOTO 6.13 - ESPELEOTEMA QUEBRADO PELA EXPANSÃO DE CRESCIMENTO DE GIPSITA

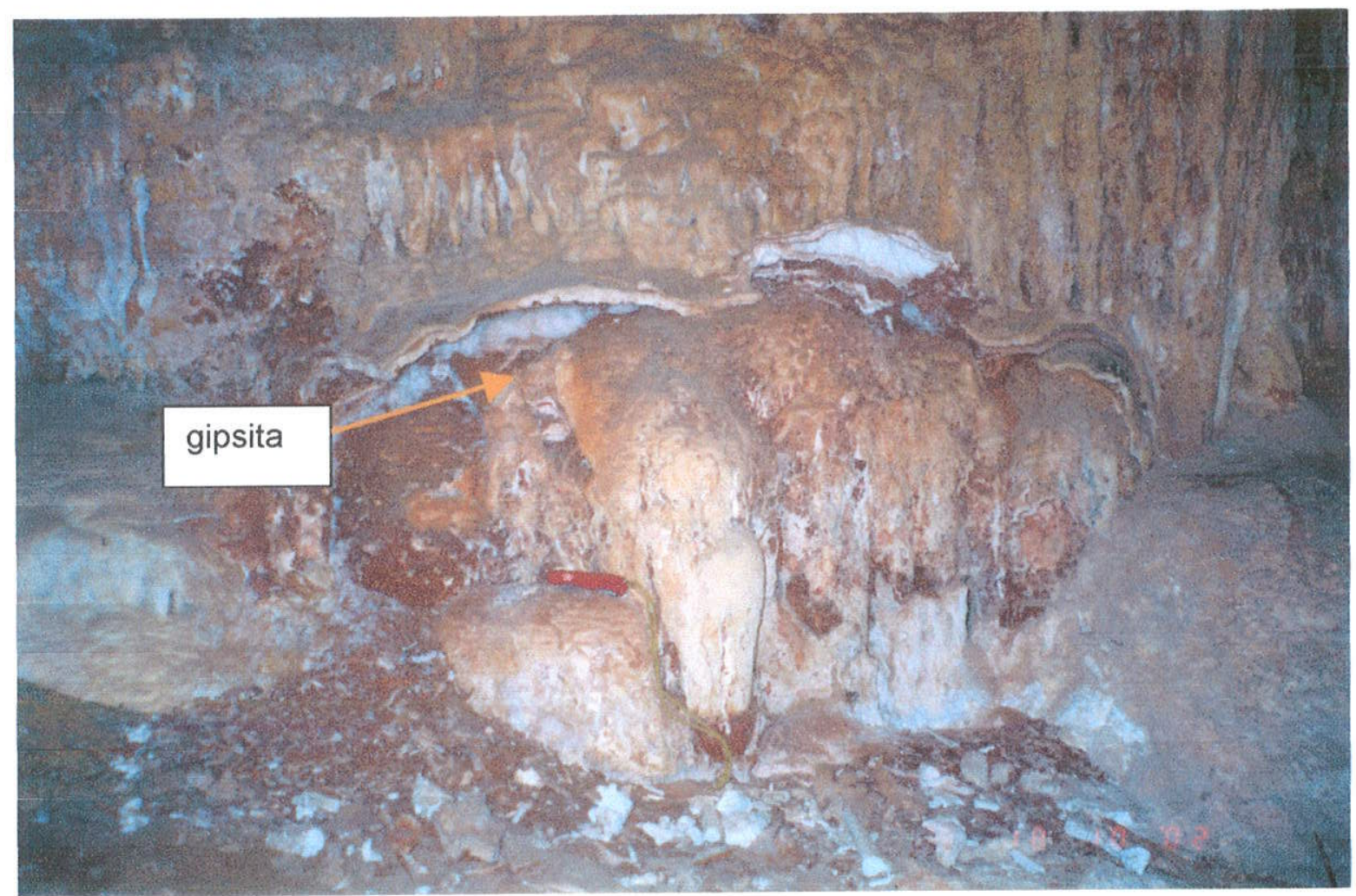

g) gipsita e epsomita e m pó

Este tipo de ocorrência é caracterizada pelo acúmulo de fragmentos na fração granulométrica entre silte e argila, que recobrem o piso atingindo espessuras centimétricas. Sua mineralogia foi identificada por difratometria de raio $\mathrm{X}$ como gipsita $\left(\mathrm{CaSO}_{4}\right)$ e epsomita $\left(\mathrm{MgSO}_{4}\right)$. O único local deste tipo de ocorrência foi observado na Toca da Boa Vista.

\section{3 - Gênese de espeleotemas de gipsita}

Laureano (1998) propõe um modelo de evolução dos condutos cársticos da área de estudo, em parte concordante com os resultados de Ferrari (1990), onde os sistemas de cavernas do setor sul da bacia de Irecê foram iniciadas e desenvolvidas através de uma evolução singenética a qual foi seguida de uma fase de ampliação paragenética, onde os condutos previamente formados sofreram um preenchimento quase total com sedimentos clásticos. Considerando este modelo de evolução e as 
conclusões da presente pesquisa sobre a origem do sulfato no sistema, pretende-se aqui, inserir a formação dos depósitos de gipsita na história evolutiva dos condutos cársticos da área de estudo.

Os resultados hidroquímicos, juntamente com a vazão do sistema cárstico estudado, evidenciaram um significativo transporte de sulfato pelo fluxo de água através do sistema, onde a fonte principal de sulfato está na rocha carbonática, provavelmente no ambiente freático, pois os teores mais elevados de sulfato foram identificados na fácies hidroquímica de percolação freática profunda. Como não há uma fonte de sulfato primário na rocha carbonática e a recarga hídrica do sistema também não contribui com sulfato, mas, há um elevado conteúdo de sulfetos, principalmente pirita, nestas rochas (Misi,1979), a origem do sulfato na água somente pode estar associada à oxidação de sulfetos. A origem dos espeleotemas de sulfato, portanto, é relacionada à percolação da água subterrânea rica neste íon no sistema $e$ principalmente às oscilações regionais do nível d'água ao longo do tempo.

A oxidação de sulfetos, sobretudo pirita, produz ácido sulfúrico (r. 4.7), que ao interagir quimicamente com as rochas carbonáticas, dissolvendo-as, disponibiliza sulfato (r. 4.8) e dióxido de carbono. $\mathrm{O} \mathrm{CO}_{2}$, em pH próximo ao neutro, tende a inibir a reatividade do ion sulfato, fazendo com que soluções ricas deste ion percolem no aqüífero sem que haja precipitação (Pohl \& White, 1965)

O último evento de subida do nível de base nos sistemas de cavernas Lapa Doce e Torrinha, e que gerou um importante registro geológico, culminou com a deposição da seqüência de topo do preenchimento clástico destes sistemas, descritos por Laureano (1998). Segundo este autor, a seqüência de topo é composta por sedimentos finos, argilo-siltosos, indicativos de um ambiente onde os condutos passaram por uma fase freática com fluxo lento, onde sofreram ampliação paragenética, resultando na morfologia atualmente observada em grande parte das cavernas.

Com o gradativo rebaixamento do nível d’água, após esta fase de ampliação paragenética, inicia-se a geração de grande parte dos depósitos de gipsita descritos no presente estudo.

A gipsita acicular (agulhas) é atribuída ao crescimento de cristais nos interstícios da zona superior dos sedimentos, onde, através da evaporação e gradativo rebaixamento do nível d'água, a solução rica em sulfato e cálcio atingem a saturação, 
precipitando gipsita (figura 6.1). Fato notável são agulhas de até $30 \mathrm{~cm}$, observadas na gruta Torrinha, que se encontram agrupadas de uma forma que lembra a margem de um lago. Interpreta-se que o crescimento destes cristais iniciou-se na porosidade do sedimento fino nas proximidades da linha do nível da água, onde o crescimento das agulhas foi alimentado lentamente pela solução do lago que migrou por capilaridade através do sedimento (figura 6.2)

O ambiente evaporítico que dominou grande parte do topo da seqüência sedimentar detrítica após o rebaixamento do nível d'água, é evidenciado pela distribuição generalizada de gretas de contração na camada síltico-argilosa do topo.

A ocorrência de crostas, descritas no item b (neste capítulo) estão também relacionadas ao rebaixamento lento do nivel d'água, onde a cristalização de gipsita ocorre acima deste. Evidenciou-se três condições de formação de crostas de gipsita:

- na interface sedimento-rocha: a deposição deste tipo de crosta ocorre durante o ressecamento e compactação dos sedimentos após o rebaixamento do nível d'água. A gipsita cristaliza-se sobre a rocha na interface com o sedimento, devido a presença de soluções ricas em sulfato nos interstícios do sedimento e condições evaporíticas instaladas com o processo de rebaixamento do nivel d'água. Neste tipo de ocorrência observou-se que os sedimentos não exibem entalhamento fluvial, como se observa em outros trechos das cavernas estudas. Por outro lado a superfície destes sedimentos encontra-se abaulada e às vezes, muito próxima ao teto do conduto. A presença de gretas de contração profundas (até $10 \mathrm{~cm}$ ) e testemunhos destes sedimentos nas paredes e tetos dos condutos, sugere que o espaço existente entre a rocha e o sedimento foi aberto em função da diminuição do volume do sedimento através de sua compactação (figura 6.3); Associa-se este mecanismo às crostas fibrosas.

- diretamente sobre a rocha a partir de exsudação: a formação desta crosta ocorre sobre a rocha a partir da exsudação de solução rica em sulfato, a qual infiltrou nas paredes do conduto durante a fase freática. Esta infiltração ocorre preferencialmente na zona alterada da rocha, a qual pode atingir cerca de $20 \mathrm{~mm}$ de espessura a partir da superficie da rocha, conforme observado nas cavernas estudadas. Com o rebaixamento do nível d'água, ocorre a exsudação da solução, por evaporação, cristalizando gipsita na forma de cristais tabulares achatados, conforme descrito no item $b$, neste capítulo. 
- sobre a rocha através de migração por capilaridade: a formação deste tipo de crosta ocorre durante o rebaixamento lento do nível d'água, em determinado momento onde o conduto esteve parcialmente preenchido por ar e água. $A$ solução que infiltra nos primeiros milímetros da parede do conduto migra por capilaridade no sentido ascendente, seguindo um gradiente de evaporação, cristalizando gipsita na parte aérea logo acima da lâmina d’água, gerando a morfologia de crosta descrita no item b, neste capítulo.

\section{FIGURA 6.1 - ESQUEMA DA FORMAÇÃO DE CRISTAIS DE GIPSITA ACICULAR POR EVAPORAÇÃO}

A

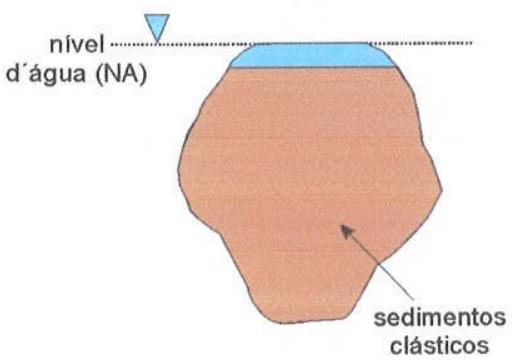

ampliação paragenética cessa quando o topo do conduto atinge o NA
B

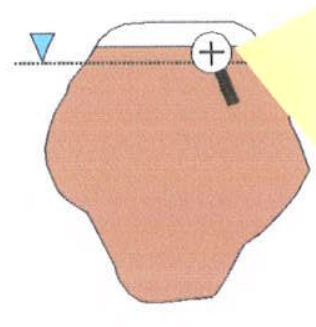

rebaixamento do NA e evaporação da água do lago

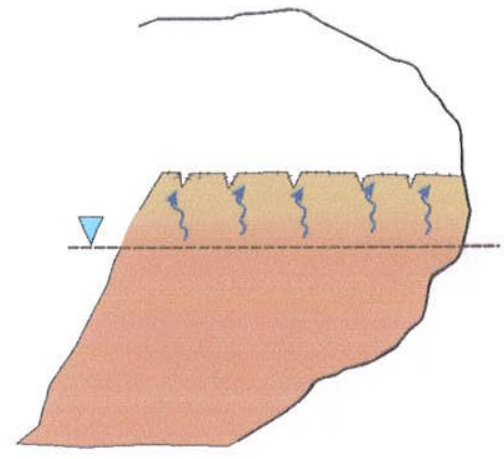

detalhe

cristalização de gipsita acicular

FIGURA 6.2 - ESQUEMA DE FORMAÇÃO DE MINERAIS DE GIPSITA POR CAPILARIDADE ATRAVÉS DO SEDIMENTO

A

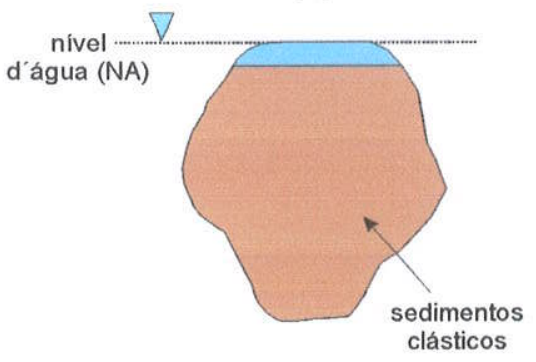

ampliação paragenética cessa quando o topo do conduto atinge o NA
B

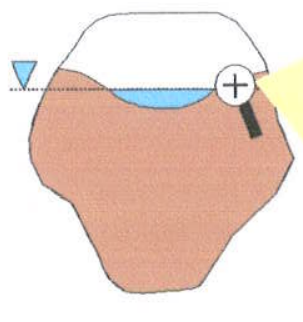

rebaixamento do NA e evaporação de solução na borda do reservatório

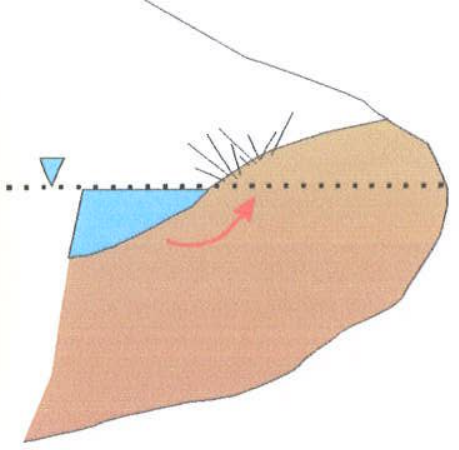

Detalhe cristalização de agulhas por evaporação na borda do reservatório 
FIGURA 6.3 - ESQUEMA DE DIMINUIÇÃO DO VOLUME DE SEDIMENTO POR COMPACTAÇÃO

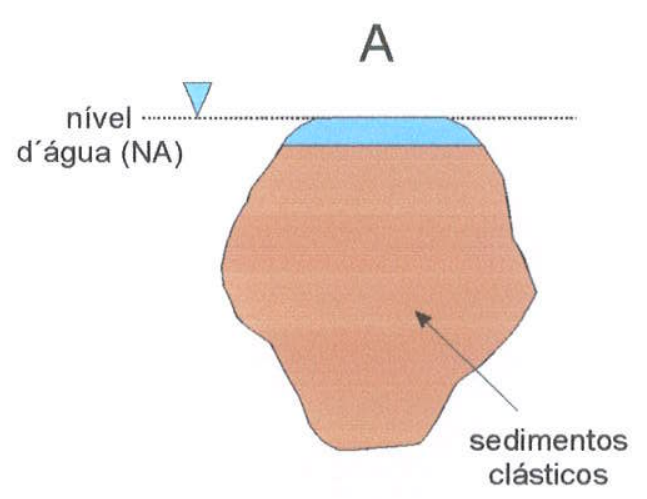

ampliação paragenética cessa quando o topo do conduto atinge o NA

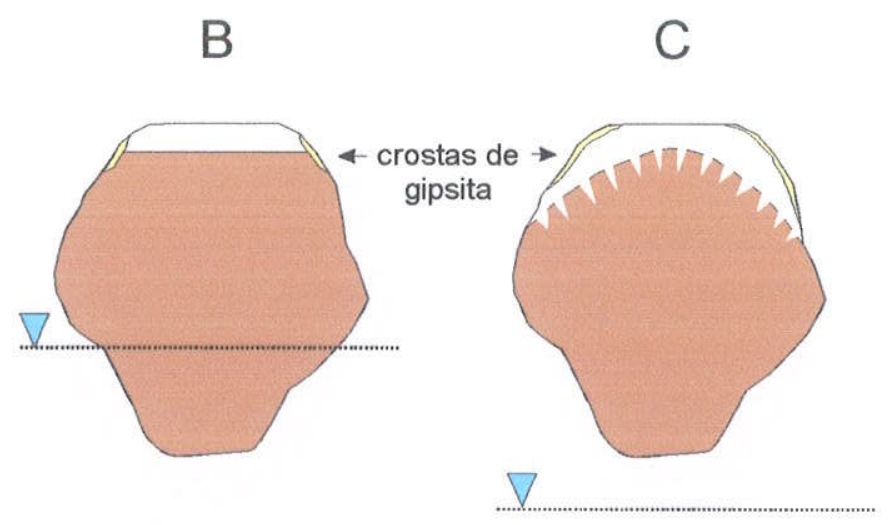

rebaixamento do NA e compactação dos sedimentos clásticos rebaixamento do NA e formação de gretas de contração

situação atual

A formação das ocorrências descritas como gipsita fibrosa, estalactites de $\mathrm{CaSO}_{4}$, filamentos e gipsita maciça granular, são interpretadas como produto da percolação vadosa de soluções ricas em sulfato ao longo do maciço carbonático.

Surge a questão sobre a origem do sulfato na percolação vadosa atual. Conforme dados estratigráficos e observações de campo, não há pirita na zona vadosa que poderia fornecer sulfato suficiente para os locais de ocorrência da gipsita associada à percolação vadosa. Atribui-se como fonte de sulfato para a percolação vadosa atual, a dissolução de gipsita depositada na porosidade secundária através do rebaixamento lento do nível d'água, análogo à formação das crostas.

A gipsita fibrosa ocorre nas condições acima descritas, sendo que o produto da dissolução da gipsita secundária percola o maciço e alcança a parede de um conduto através de um capilar onde, por exsudação, deposita gipsita na forma fibrosa.

As pontas de estalactites de $\mathrm{CaSO}_{4}$ ocorrem da mesma maneira que o descrito acima, com a diferença de que a solução percolante intercepta os canalículos responsáveis pela formação da estalactite. 


\section{CAPÍTULO 7 - GEOQUÍMICA DOS ISÓTOPOS ESTÁVEIS DE ENXOFRE E CARBONO}

\section{1 - Introdução}

No processo de carstificação, as rochas carbonáticas sofrem reações de dissolução, que são promovidas principalmente pelo ácido carbônico, devido à disponibilidade global de $\mathrm{CO}_{2}$ no solo, contudo, no presente estudo, observou-se que há também a participação do ácido sulfúrico como agente corrosivo. A isotopia do $\mathrm{S} e$ $\mathrm{C}$, através das razões isotópicas de ${ }^{34} \mathrm{~S} /{ }^{32} \mathrm{~S}$ e ${ }^{13} \mathrm{C} /{ }^{12} \mathrm{C}$, contribui no sentido de elucidar a origem do enxofre e carbono nos processos cársticos e os tipos de reações químicas envolvidas.

Yonge \& Krouse (1987), através de análise isotópica de $S$ em minerais de caverna, concluíram que pirita, disseminada na rocha matriz, é a possível fonte para a grande quantidade de gipsita encontrada. Krothe \& Libra (1983), concluíram que a atividade microbiana tem forte implicação no fracionamento dos isótopos de $S$ no ambiente freático de aqüíferos cársticos. Yoshimura et al (2001) concluíram que a fonte de $\mathrm{C}$ do íon $\mathrm{HCO}_{3}{ }^{-}$é oriunda da rocha carbonática e de $\mathrm{CO}_{2}$ de origem profunda, em detrimento do $\mathrm{CO}_{2}$ do solo.

$\mathrm{Na}$ presente pesquisa, investigou-se a composição isotópica do enxofre em sulfeto e sulfato, e de carbono em rocha e hidrogenocarbonato. $O$ enxofre foi analisado em pirita disseminada em rocha carbonática, sulfato de minerais secundários de caverna (espeleotemas) formados por gipsita e de sulfato obtido pela precipitação do ín em água subterrânea; já o carbono foi investigado a partir de rocha carbonática e de carbonato precipitado de água subterrânea.

O enxofre está distribuido nas três esferas terrestres. Ocorre na forma oxidada de sulfato, por exemplo, nas rochas evaporíticas, e na forma reduzida, como sulfeto, em minerais associados aos processos formadores de rochas. $O$ enxofre tem quatro isótopos, sendo: ${ }^{32} \mathrm{~S}-95,02 \% ;{ }^{33} \mathrm{~S}-0,75 \% ;{ }^{34} \mathrm{~S}-4,21 \%$ e ${ }^{36} \mathrm{~S}-0,02 \%$. A composição isotópica é expressa em termos de $\delta^{34} S$ (Faure,1986). Os valores de $\delta^{34} S$ são determinados a partir do uso do padrão CDT - Canyon Diablo Troilite, um meteorito ferroso, no qual a razão isotópica de $\delta^{34} \mathrm{~S} / \delta^{32} \mathrm{~S}$ é de 22,22 , valor muito similar à de rochas ígneas máficas, o que o torno um referencial eficaz (Hoefs, 1997). 
O carbono ocorre na Terra sob a forma de inúmeros compostos, orgânicos e inorgânicos, onde se destaca sua ocorrência sob a forma de dióxido de carbono e carbonato. Tem dois isótopos estáveis: ${ }^{12} \mathrm{C}-98,89 \%$ e ${ }^{13} \mathrm{C}-1,11 \%$, sendo a composição isotópica expressa em termos de $\delta^{13} \mathrm{C}$, através da relação:

$\delta^{13} \mathrm{C}=\left[\left({ }^{13} \mathrm{C} /{ }^{12} \mathrm{C}\right)_{\text {amostra }} /\left({ }^{13} \mathrm{C} /{ }^{12} \mathrm{C}\right)_{\text {referência }}-1\right] \times 1000$.

As variações de $\delta^{13} \mathrm{C}$ são expressas em valores por mil (\%o) em relação a um padrão denominado PDB-Viena (Pee Dee Belemnite) (Hoefs, op.cit).

Com o objetivo de completar e ampliar a base de dados isotópicos, além dos dados produzidos no presente estudo, foram também utilizados informações referentes aos trabalhos realizados por Misi \& Kyle (1994), Kyle \& Misi(1997), Misi \& Veizer (1998) e Auler (1999), cujos dados estão dispostos na tabela 7.1

\section{2 - Dados isotópicos do carste estudado}

\subsection{2 - Isótopos de enxofre}

A utilização da razão isotópica ${ }^{34} \mathrm{~S} /{ }^{32} \mathrm{~S}$, no presente estudo, tem o propósito de diagnosticar a assinatura isotópica do enxofre em diferentes compartimentos do carste. Diferente do carbono, o enxofre não fraciona em virtude de processos de precipitação e evaporação, mas sim, através de reações de redução e oxidação (Krouse, 1967). Na região de estudo a principal fonte de $S$ são os sulfetos, principalmente pirita. A pirita pode ser oxidada por processos abióticos e microbianos (Stumm \& Morgan, 1995).

A oxidação de sulfetos através de ação microbiana, resulta em sulfatos com empobrecimento de ${ }^{34} \mathrm{~S}$ entre $2 \%$ a $5 \%$ (Toran \& Harris, 1989). O fracionamento devido a ação de bactérias redutoras de sulfato (BRS) gera uma amplitude entre $4 \%_{0} \mathrm{e}$ $46 \%$ no $\delta^{34} S$ do sulfeto (Canfield \& Thamdrup,1994) e empobrecimento de ${ }^{34} \mathrm{~S}$ em $7 \%$ em relação ao $S$ da rocha (Yonge \& Krouse, 1987).

No presente estudo, utilizou-se como referencia de $\delta^{34} S$ de pirita dados obtidos em Misi \& Kyle (1994), Kyle \& Misi(1997) e Misi \& Veizer (1998), uma vez que os dados obtidos no presente estudo apresentaram problemas de ordem analítica. 
TABELA 7.1 - DADOS ISOTÓPICOS DE SULFATOS E SULFETOS - GRUPO UNA

\begin{tabular}{|c|c|c|c|c|}
\hline $\begin{array}{c}\text { dados isotópicos } \\
\delta^{34} \mathrm{~S} \% \text { (CDT) } \\
\text { ocorrência }\end{array}$ & & $\begin{array}{c}\text { Misi \& Kyle (1994) } \\
\text { Kyle \& Misi(1997) } \\
\text { Misi \& Veizer (1998) }\end{array}$ & Auler (1999) & este estudo \\
\hline pirita & $\begin{array}{c}\text { media } \\
\max \\
\min \\
\mathrm{n}\end{array}$ & $\begin{array}{c}21.3 \\
22.6 \\
19.1 \\
9 \\
\end{array}$ & & \\
\hline $\begin{array}{l}\text { outros sulfetos } \\
\qquad \mathrm{Pb}-\mathrm{Zn}\end{array}$ & $\begin{array}{c}\text { media } \\
\max \\
\min \\
\mathrm{n} \\
\end{array}$ & $\begin{array}{c}20.9 \\
25.1 \\
12.3 \\
9 \\
\end{array}$ & & \\
\hline $\begin{array}{c}\text { sulfeto } \\
\text { disseminado }\end{array}$ & $\begin{array}{c}\text { media } \\
\max \\
\min \\
\mathrm{n}\end{array}$ & & & $\begin{array}{c}19.9 \\
32.6 \\
9.6 \\
8 \\
\end{array}$ \\
\hline $\begin{array}{c}\text { gipsita } \\
\text { (espeleotema) }\end{array}$ & $\begin{array}{c}\text { media } \\
\max \\
\min \\
\mathrm{n} \\
\end{array}$ & & & $\begin{array}{c}21.6 \\
28.7 \\
15.0 \\
10 \\
\end{array}$ \\
\hline $\begin{array}{l}\text { água subterrânea } \\
\text { (ppt) }\end{array}$ & $\begin{array}{c}\text { media } \\
\max \\
\min \\
\mathrm{n}\end{array}$ & & $\begin{array}{c}15.7 \\
22.3 \\
11.9 \\
12\end{array}$ & $\begin{array}{c}17.7 \\
22.2 \\
14.6 \\
16\end{array}$ \\
\hline
\end{tabular}

O gráfico da figura 7.1 permite observar que $0 \delta^{34} S$ do sulfato da água subterrânea $\left(\delta^{34} \mathrm{~S}\right.$ médio de $17,7 \%$ ), obtido a partir de precipitação em laboratório, é empobrecido em relação a pirita $\left(\delta^{34} S\right.$ médio de $21,3 \%$ ), porém, com variação dentro da amplitude prevista para processos de oxidação com participação microbiana. Interpreta-se, desta forma, uma vez que o sulfato, oriundo da precipitação de amostras do aqüífero, exibe $\delta^{34} S$ similar, ou levemente empobrecido, em relação ao $\delta^{34} S$ do sulfeto na rocha carbonática, que deve ocorrer oxidação de pirita em ambiente freático, de forma semelhante ao que foi deduzido por Nakai \& Jansen (1964). A oxidação de pirita gera ácido sulfúrico a partir de catálise microbiana (Toran \& Harris, 1989; Ball \& Jones, 1990), o que permite confirmar a participação de ácido sulfúrico no sistema estudado. 
Os valores de $\delta^{34} \mathrm{~S}$ em gipsita (espeleotemas, tabela 7.1), incluem a faixa de variação do $\delta^{34} \mathrm{~S}$ de pirita, porém, exibem uma amplitude maior, com valores mais pesados, em relação à pirita e ao sulfato precipitado de água subterrânea. Interpreta-se este fato como sendo causado pela contribuição de $\mathrm{S}$ mais pesado, detectado na forma de sulfeto disseminado contido na rocha (tabela 7.1), que ao ser oxidado fornece sulfato para a gipsita com a mesma assinatura isotópica de $\delta^{34} S$ deste sulfeto disseminado. Ressalta-se que os sulfetos disseminados apresentam uma grande variação dos valores de $\delta^{34} S$ devido ao fato destes representarem uma mistura de variados tipos de sulfetos, além da pirita, como também incluírem $S$ de matéria orgânica, evidenciada pela coloração negra da rocha carbonática e pelo odor de $\mathrm{SO}_{2}$ quando partida.

FIGURA 7.1 - COMPOSIÇÃO ISOTÓPICA DO ENXOFRE EM DIFERENTES COMPARTIMENTOS NO CARSTE ESTUDADO. (*1) - MISI \& KYLE (1994), KYLE \& MISI (1997), MISI \& VEIZER (1998) ; (*2) ESTE ESTUDO ; (*3) AULER (1999)

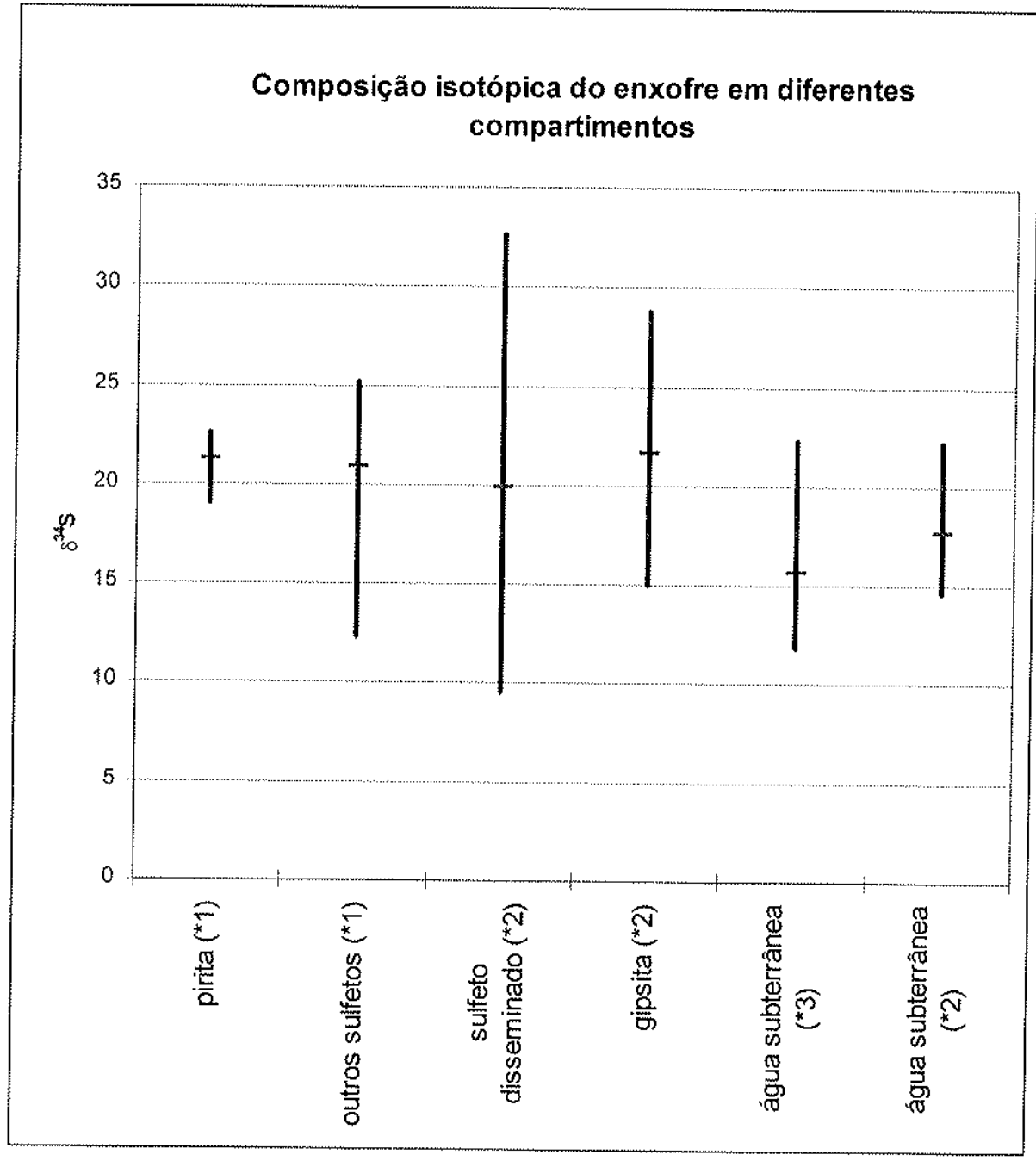




\subsection{2 - Isótopos de carbono}

Para aplicar o $\delta^{13} \mathrm{CHCO}_{3}$ no presente estudo, visando definir a participação das reações abaixo, no sistema cárstico estudado,

$$
\begin{gathered}
\left.\mathrm{CaCO}_{3}+\mathrm{H}_{2} \mathrm{CO}_{3}=\mathrm{Ca}^{2+}+2 \mathrm{HCO}_{3}{ }^{-} \quad \text { (r. } 7.1\right) \mathrm{e} \\
\left.2 \mathrm{CaCO}_{3}+\mathrm{H}_{2} \mathrm{SO}_{4}=2 \mathrm{Ca}^{2+}+2 \mathrm{HCO}_{3}{ }^{-}+\mathrm{SO}_{4}{ }^{2-} \quad \text { (r. } 7.2\right),
\end{gathered}
$$

foram consideradas as seguintes possibilidades:

1. reação (r. 7.1) dominante no sistema estudado

Nesta reação o fracionamento isotópico entre o $\mathrm{CO}_{2}$ (aq) do solo e o $\mathrm{HCO}_{3}^{-}$(aq), em condições de $\mathrm{pH}$ neutro e $25^{\circ} \mathrm{C}$, é de $7,9 \%$ (Clark \& Fritz, 1997). No presente estudo o $\delta^{13} \mathrm{C}_{\mathrm{CO}_{2}}$ não foi analisado, contudo, considerando que a região é coberta por vegetação de mata, arbustos e plantações, que correspondem ao tipo C3 (Clark \& Fritz, op.cit), com $\delta^{13} \mathrm{C}_{\mathrm{CO}_{2}}$ entre $-30 \%$ e $-20 \%$, o valor intermediário de $-25 \%$ foi adotado.

Considerando o enriquecimento em $7,9 \%$ sobre $-25 \%$, obtém-se o valor de $-17,1 \%$, que corresponderia ao $\delta^{13} \mathrm{CHCO}_{3}$ associado à reação (r. 7.1) para a área de estudo. Assim, os valores mais próximos de $-17,1 \%$, para $\delta^{13} \mathrm{C}_{\mathrm{HCO}_{3}}$, devem corresponder às amostras nas quais ${\mathrm{o} \mathrm{HCO}_{3}}^{-}$foi produzido através da reação (r. 7.1), enquanto que, os mais distantes, teriam influência maior do $\delta^{13} \mathrm{C}$ da rocha, ou seja, tenderiam a ser enriquecidos em ${ }^{13} \mathrm{C}$.

2. reação (r. 7.2) dominante no sistema estudado

Nesta reação o $\mathrm{C}$ do $\mathrm{HCO}_{3^{-}}$é oriundo do $\mathrm{CaCO}_{3}$ (rocha), não havendo intercâmbio isotópico com $\mathrm{C}$ de outra natureza. Portanto, o $\delta^{13} \mathrm{C}_{\mathrm{HCO}_{3}}$ desta reação deve acompanhar o valor de $\delta^{13} \mathrm{C}$ rocha, ou seja, entre $-4 \%$ e $0,1 \%$.

Observando os resultados analíticos (tabela 7.2), verificam-se valores de $\delta^{13} \mathrm{C}_{\mathrm{HCO}_{3}}$ nas águas subterrâneas de $-10,4 \%$, que, em comparação com o valor previsto para a reação (r.7.1) $(-17,1 \%$ ) , são muito enriquecidos. Neste caso, interpreta-se que há influência significativa de ${ }^{13} \mathrm{C}$ oriundo da rocha, produto da dissolução de $\mathrm{CaCO}_{3}$ 
não influenciada unicamente por $\mathrm{H}_{2} \mathrm{CO}_{3}$. Portanto, nestas condições, atribui-se a presença de $\mathrm{HCO}_{3}$ - mais pesado ao produto da reação entre $\mathrm{CaCO}_{3}$ e $\mathrm{H}_{2} \mathrm{SO}_{4}$.

Relacionando esta interpretação à localização da amostra no aqüifero e suas caracteristicas hidroquímicas, nota-se que trata-se de uma água de percolação freática profunda, rica em sulfato $(\bar{x}=746,07 \mathrm{mg} / \mathrm{L})$ e relativamente pobre em $\mathrm{HCO}_{3}{ }^{-}(\bar{x}=388,09$ $\mathrm{mg} / \mathrm{L})$. Esta interpretação isotópica do $\delta^{13} \mathrm{C}$ coincide com as conclusões hidroquímicas sobre ação de ácido sulfúrico no aqüifero profundo.

As águas com valores de $\delta^{13} \mathrm{CHCO}_{3}$ mais próximos de $17,1 \%$, são interpretadas como dominadas pela reação (r. 7.1), mas, em função das características hidroquímicas, considera-se a existência de um sistema misto de corrosão da rocha carbonática, com a ação simultânea de ácido sulfúrico e ácido carbônico.

\begin{tabular}{|c|c|c|c|c|c|}
\hline Amostra & Fácies & $\begin{array}{c}\delta^{13} \mathrm{C} \\
\mathrm{PDB}(\%)\end{array}$ & KAIVEA & & $\begin{array}{c}\delta^{13} \mathrm{C} \\
\operatorname{PDB}(\%)\end{array}$ \\
\hline ba-62 & 3 & -16.0 & & media & $-2,07$ \\
\hline ba-42 & 3 & -12.7 & Rochas carbonáticas & $\max$ & $-4,32$ \\
\hline ba-55 & 3 & -16.2 & & $\min$ & 0,163 \\
\hline ba-78 & 3 & -12.9 & & $n$ & 14 \\
\hline ba-26 & 3 & -12.9 & & media & $-14,61$ \\
\hline ba-44 & 3 & -10.4 & Águas subterrâneas (ppt) & $\max$ & $-17,47$ \\
\hline ba- 57 & 3 & -16.6 & & $\min$ & $-10,45$ \\
\hline ba-61 & 3 & -20.5 & & $n$ & 19 \\
\hline ba-73 & 3 & -14.4 & & & \\
\hline ba-56 & 3 & -16.9 & & & \\
\hline ba-77 & 3 & -14.7 & & & \\
\hline ba-64 & 4 & -17.5 & & & \\
\hline ba-54 & 5 & -15.1 & & & \\
\hline ba-79 & 5 & -15.3 & & & \\
\hline ba-60 & 5 & -12.4 & & & \\
\hline ba-71 & 5 & -12.3 & & & \\
\hline ba- -58 & 6 & -16.9 & & & \\
\hline ba-70 & 6 & -16.0 & & & \\
\hline
\end{tabular}


FIGURA 7.2 - COMPOSIÇÃO ISOTÓPICA DO CARBONO EM DIFERENTES COMPARTIMENTOS

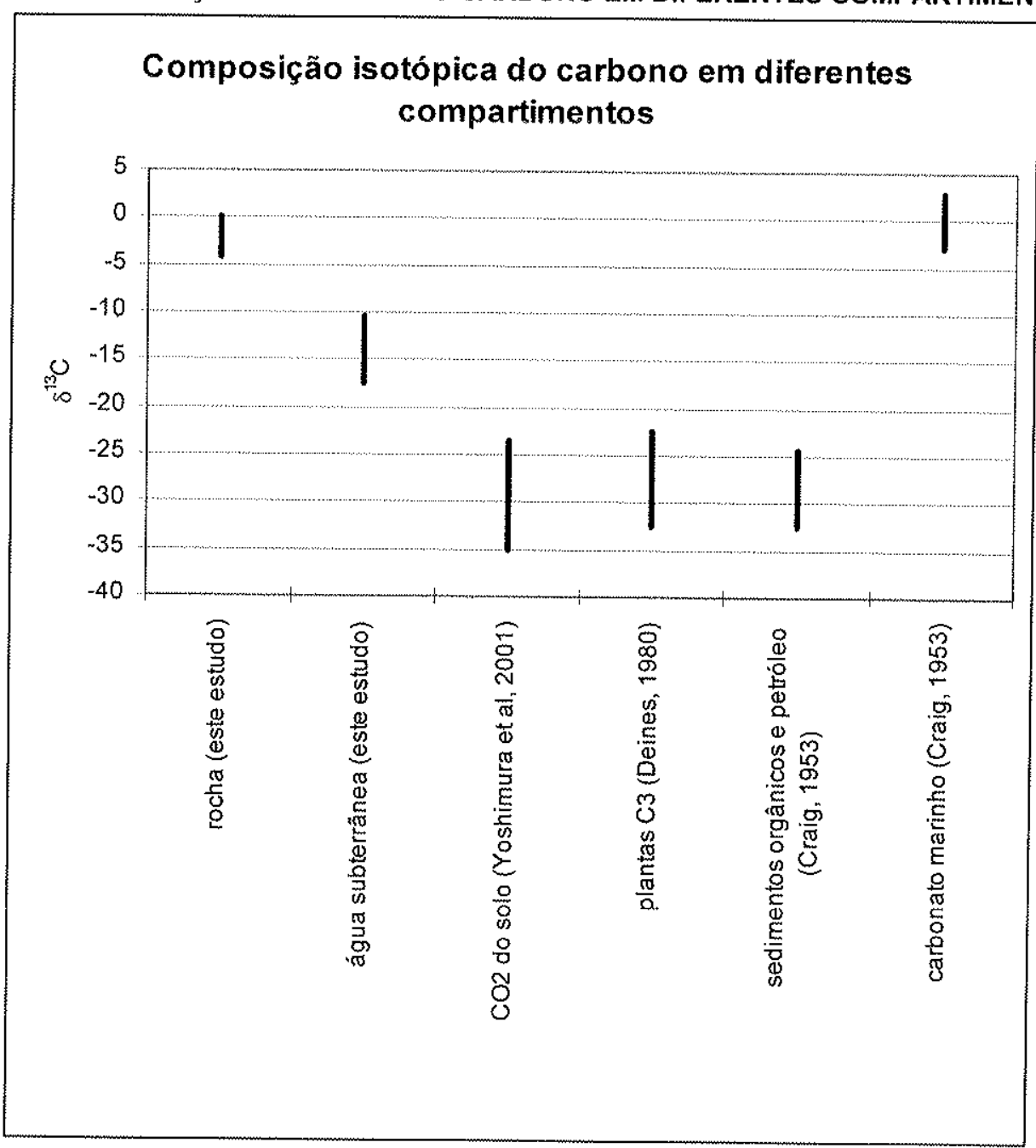




\section{CAPÍTULO 8 - ASPECTOS MICROBIOLÓGICOS DO CARSTE ESTUDADO}

\section{1 - Introdução}

Os processos espeleogenéticos associados à ação de ácido sulfúrico freqüentemente encontram associação com participação microbiana (Morehouse, 1968; Ball \& Jones, 1990; Hose et al, 2000), pois na natureza o ciclo biogeoquímico do enxofre é totalmente baseado em reações biológicas, controladas por bactérias e microorganismos específicos (Forti, 1988), e essenciais à continuidade desses ciclos (Hoefs 1997; Tortora et al 2000). Nesses ciclos, os microorganismos reciclam componentes químicos, decompondo matéria orgânica e transformando compostos carbonatados, nitrogenados, fosfatados e sulfurosos em formas utilizáveis por outros organismos vivos, através de reações de oxi-redução que fornecem suas necessidades metabólicas (Tortora et al, op cit).

Entre as bactérias enxofre-oxidantes encontram-se as do gênero Thiobacillus, que compreendem bacilos Gram-negativos, medindo aproximadamente 0,5 por 1,0 a $4,0 \mu \mathrm{m}$. A taxonomia deste gênero tem sido amplamente reorganizada. Muitas espécies autótrofas foram recentemente consideradas pertencentes ao novo gênero Thiomonas, outras espécies são atualmente classificadas como membros do gênero Thiomicrospira, incluindo as novas espécies de ecossistemas marinhos. A espécie $T$. novellus foi reclassificada como Starkeya novella, mas em geral devido a inúmeros estudos de reclassificação taxonômica neste estudo será empregado o gênero Thiobacillus quando referir a todo o grupo.

A energia para o metabolismo do Thiobacillus é obtida através da oxidação de um ou mais compostos reduzidos de enxofre, incluindo sulfetos, enxofre elementar, tiossulfato, politionatos e tiocianato. O sulfato geralmente é o produto final, mas podem formar-se transitoriamente enxofre, sulfitos e politionatos (Pankhurst, 1964; Parker \& Prist, 1953).

Entre as espécies de Thiobacillus, o T.ferrooxidans é a única espécie do gênero capaz de obter energia por oxidação da pirita e do íon ferroso conforme as reações apresentadas a seguir (Kuenen et al, 1992; Gragnolino \& Tuovinen, 1984; Vishniac \& Santer, 1957). 


$$
\begin{aligned}
& 2 \mathrm{FeS}_{2}+2 \mathrm{H}_{2} \mathrm{O}+7 \mathrm{O}_{2} \rightarrow 2 \mathrm{FeSO}_{4}+2 \mathrm{H}_{2} \mathrm{SO}_{4} \\
& 4 \mathrm{FeSO}_{4}+\mathrm{O}_{2}+2 \mathrm{H}_{2} \mathrm{SO}_{4} \rightarrow 2 \mathrm{Fe}_{2}\left(\mathrm{SO}_{4}\right)_{3}+2 \mathrm{H}_{2} \mathrm{O}
\end{aligned}
$$

A presença deste grupo na natureza é governada por uma complexa interação entre fatores químicos, físicos e microbiológicos. Um fator crucial é a presença simultânea de um aceptor (oxigênio ou óxido de nitrogênio) e de um doador (um composto de enxofre reduzido) de elétrons. O sulfeto é um dos substratos naturais mais importantes e muitas bactérias deste grupo podem ocorrer na estreita faixa de gradiente onde coexistem o oxigênio e o sulfeto. Estes gradientes podem ser encontrados, por exemplo, em lagos estratificados e na interface entre o sedimento anaeróbio e a coluna d'água. No entanto, é ainda mais freqüente em micronichos existentes em ambientes que contem bolsões anaeróbios. Níveis muito altos de transformação de sulfetos já foram relatados em ambientes com niveis muito baixos de sulfeto e oxigênio $\left(<10^{-6} \mathrm{mM}\right)$. Também já foi relatado que diferentes espécies de Thiobacillus respondem diferentemente frente a potenciais redox variados.

A ocorrência de bactéria acidofílica em ambientes aparentemente neutros indica a existência de gradientes de $\mathrm{pH}$ associados a micronichos ácidos. Os microrganismos oxidantes de enxofre têm sido isolados de locais onde existe a presença esperada de compostos inorgânicos de ferro e enxofre. Os Thiobacillus, especialmente aqueles quimiolitotróficos obrigatórios, tem sido relatados como um dos grupos de microrganismos que mais contribuem para a transformação do enxofre na natureza, apesar de poucos estudos sistemáticos de sua distribuição na natureza terem sido realizados. Entretanto, existem evidências de que, dependendo de condições particulares de cada ambiente, as bactérias oxidantes de enxofre heterotróficas ou mixotróficas (autotróficas facultativas) podem ser consideradas igualmente importantes na conversão de compostos reduzidos de enxofre.

Um fator que pode limitar o crescimento dos Thiobacillus é a disponibilidade de compostos inorgânicos reduzidos de enxofre, uma limitação especialmente importante para os autótrofos obrigatórios que dependem completamente deste composto para crescer.

Outro grupo importante de bactérias, associadas ao do ciclo do enxofre, são as bactérias redutoras de sulfato (BRS), estritamente anaeróbias, que compreendem os gêneros Desulfovibrio (não esporuladas) e Desulfomaculum (esporuladas). No 
processo de respiração dessas bactérias o ion sulfato atua como aceptor final de elétrons em lugar do oxigênio produzindo sulfeto de hidrogênio $\left(\mathrm{H}_{2} \mathrm{~S}\right)$. O sulfeto de hidrogênio pode ser oxidado por Thiobacillus, formando ácido sulfúrico (Hose et. al., 2000).

\section{2 - Pesquisa de Acithiobacillus ferooxidans}

Resultados negativos foram encontrados para a pesquisa de Acidithiobacillus thiooxidans, Acidithiobacillus ferrooxidans e Thiobacillus denitrificans nas amostras de água analisadas.

No entanto os resultados para a presença presuntiva de Thiobacillus thioparus obtido pela análise realizada pela técnica dos tubos múltiplos foi positivo para todos os locais de amostragem realizados (Tabela 8.1). Alguns locais não foram positivos em $100 \%$ das amostragens realizadas.

O T. thioparus é um bacilo quimiolitotrófico obrigatório, que depende da oxidação de formas inorgânicas e reduzidas de enxofre para obter energia. Esta espécie já foi isolada de ambientes diversos como águas superficiais, sedimentos estuarinos e marinhos e também foi identificado por métodos independentes de cultivo (genéticos) ou através de enriquecimentos de amostras de água de cavernas, como a Movile Cave, na Romênia.(Vlasceanu et al, 1997). Nesta caverna uma cepa de T. thioparus LV43 foi isolada e sua distribuição verificada em locais aeróbios e de $\mathrm{pH}$ neutros dentro da caverna e também no entorno da mesma, em águas superficiais e subterrâneas em aqüiferos comuns aos da Movile Cave. Na presente pesquisa, na Bacia do Irecê, $T$. thioparus também foram isolados no interior de cavernas, em águas superficiais e subterrâneas nos sistemas cársticos da região.

Muitas bactérias oxidantes do enxofre vivem em fontes, lagos e em biofilmes formados em paredes e outros ambientes de caverna. Muitas destas são acidofílicas e produzem ácido sulfúrico, podendo contribuir para a compreensão da espeleogênese (Engel et al, 2000 e 2001). Resultados de diferentes estudos já comprovaram a existência de uma grande diversidade de bactérias enxofre-oxidantes vivendo em sistemas cársticos, onde este metabolismo tem um impacto significativo na dissolução das rochas carbonáticas (Hose \& Piscarowicz 1999). A maioria dos estudos microbiológicos relatados em sistemas cársticos trata de ambientes de cavernas com alta produção de ácido sulfúrico e exibem grande formação de biofilmes ou mantas 
microbianas, visíveis a olho nu, presentes na forma de biomassa flutuante na água, filamentos e formas de diferentes cores acompanhando a direção dos fluxos de água ou mesmo nas paredes de diferentes cavernas. Exemplos destas cavernas são Movile Cave, Romênia; Grota Grande Del Vento-Grotta Del Fiume, Itália ; Ceespool Cave, Virgínia; Lower Kane Cave, Wyoming and Parker Cave, Kentucky (Hubbard et al, 1990; Engel, 2000). Nestes locais além de bactérias redutoras e oxidantes de enxofre, foram também relatados que nos biofilmes e filamentos microbianos existe a predominância de grupos de microrganismos pertencentes o gênero "Epsilonproteobactéria" (Engel et al, 2003). O significado ecológico destes grupos ainda não é bem conhecido mas possivelmente estão associados ao ciclo do carbono e enxofre em ambientes extremos.

Fontes sulfatadas mesofilicas são menos estudadas, no entanto Elshahed et al (2003) descreveram uma rica diversidade de bactérias presentes em uma fonte sulfatada mesofílica em Oklahoma, indicando a ocorrência do ciclo do enxofre em amostras de mantos microbianos na região da fonte. No presente estudo, formações de biofilmes ou de mantos microbianos não foram observadas nos ambientes das cavernas pesquisadas.

Apesar de não terem sido detectados nas amostras de água, Acidithiobacillus ferrooxidans foram isolados nas amostras de pirita presente em rochas da Lapa do Sumidouro e do sedimento da Gruta Azul, sendo que neste último também foram isolados T. thioparus (Tabela 8.1). A pirita pode ser oxidada por processos abióticos ou microbianos. Em condições aeróbias a oxidação microbiana da pirita é mais rápida do que em anaerobiose, mas os dois processos são possiveis. Dependendo das condições ambientais grupos diferentes envolvidos neste processo já foram relatados, mas o Acithiobaciilus ferooxidans é o mais estudado. Processos na biolixiviação da pirita ainda não estão totalmente elucidados, o próprio processo de adesão das células à pirita não tem sido diretamente relacionado à capacidade de lixiviação (Baldi et al 1992). Yu et al (2001) tentando descrever os processos que mediam a oxidação da pirita por $A$ ferrooxidans, indicaram a existência de competição entre diferentes oxidantes do sulfeto, e não do ferro, os quais podem também auxiliar na dissolução do ferro reduzido. 
TABELA 8.1. RESUltados FINAIS dA PRESENÇA (P) OU AusÊNCIA (A) DAS BACTÉRIAS OXIDANTES (THIOBACILLUS THIOPARUS E ACITHIOBACILLUS FEROOXIDANS) EM AMOSTRAS DE ROCHAS E SEDIMENTOS.

\begin{tabular}{cccc}
\hline Amostra & Pontos de coleta & $\begin{array}{c}\text { Acidithiobacillus } \\
\text { ferrooxidans }\end{array}$ & $\begin{array}{c}\text { Thiobacillus } \\
\text { thioparus }\end{array}$ \\
\hline BA 79 pirita & Lapa do Sumidouro & $\mathrm{P}$ & $\mathrm{A}$ \\
LS1 rocha - pirita & Gruta Azul & $\mathrm{P}$ & $\mathrm{nr}$ \\
sedimento & Toca da barriguda & $\mathrm{P}$ & $\mathrm{P}$ \\
Rocha & Torrinha cortinas & $\mathrm{nr}$ & $\mathrm{A}$ \\
Gt1 sedimento & Tra & $\mathrm{A}$ \\
\hline $\mathrm{nr}$ : não realizado & & &
\end{tabular}

\section{3 - Pesquisa de Bactérias Reduroras de Sulfato (BRS)}

Já a pesquisa de bactérias redutoras do sulfato, que realizam as reações (r. 8.3) e (r. 8.4), foram positivas para cinco das 15 amostras analisadas, sendo os resultados positivos encontrados em amostras coletadas de poços e não nos reservatórios, nascentes ou amostras de gotejamento de estalactites nas cavernas amostradas. Por serem amostras de poços profundos as amostras positivas podem apresentar melhores condições para as redutoras de sulfato, por serem anaeróbios estritos. Por terem hibridizado com a sonda empregada na técnica de $\mathrm{FISH}$, as bactérias redutoras de enxofre encontradas podem pertencer às famílias Desulfovibrionaceae e Desulfobacteriaceae.

$$
\begin{gathered}
2 \mathrm{CH}_{3} \mathrm{CHOHCOO}^{-}+3 \mathrm{SO}_{-4}^{-} \rightarrow 2 \mathrm{CH}_{3} \mathrm{COO}^{-}+2 \mathrm{HCO}_{3}^{-}+\mathrm{HS}^{-}+\mathrm{H}^{+} \quad \Delta \mathrm{G}^{\circ} \mathrm{kJ} / \mathrm{mol} \text { reação }=-160,1 \quad \text { (r. 3) } \\
2 \mathrm{CH}_{3} \mathrm{CHOHCOO}^{-}+3 \mathrm{SO}^{2-}{ }_{4} \rightarrow 6 \mathrm{HCO}_{3}+3 \mathrm{HS}^{-}+\mathrm{H}^{+} \Delta \mathrm{G}^{\circ} \mathrm{kJ} / \mathrm{mol} \text { reação }=-255,3 \quad \text { (r. 4) }
\end{gathered}
$$

As BRS para o ciclo do enxofre são importantes na geração do enxofre sob a forma de gás, de alguma forma deslocando-o dos compostos encontrados sob a forma não gasosa do enxofre. O gás sulfídrico pode se tornar tóxico aos ambientes em que se encontram, favorecendo reações de corrosão entre outras. As espécies Desulfovibrio sp. constituem um grupo comum das BRS, e são facilmente encontradas em ambientes anóxicos nos quais fontes como o hidrogênio e o ácido acético estejam naturalmente presentes. A presença desse grupo, como constatado pelo método $\mathrm{FISH}$, pode indicar disponibilidade desses substratos nas amostras positivas.

Os microrganismos envolvidos no processo de oxi-redução do enxofre encontrados em algumas das amostras podem estar ligados as transformações 
biogeoquímicas do ciclo do enxofre. Cavernas como Lower Cave, em Wyoming, relataram a ocorrência deste ciclo em mantos microbianos que formam nas fontes de água um complexo sistema microbiano apoiado pela produção primária dos enxofres oxidantes, porem sustentados pelas bactérias redutoras do sulfato e bactérias heterotróficas (Engel, 2000). Portanto, descrevem sistemas onde ocorre a ciclagem de nutrientes por fixação autotrófica de carbono pelos quimiorganotróficos e populações heterotróficas e também produzem sulfeto pelas BRS que são utilizados pelas enxofre oxidantes como os Thiobacillus. Estes processos foram ainda pouco estudados em ecossistemas subterrâneos.

O resultado presuntivo positivo para Thiobacillus thioparus é avaliado pela viragem do $\mathrm{pH}$ do meio de cultura de vermelho $(\mathrm{pH} \mathrm{7,4)}$ para amarelo (abaixo de 6.5). Para investigar a produção de ácido no meio contendo tiossulfato como fonte de energia foram realizadas medições de $\mathrm{pH}$ em diferentes períodos de incubação das amostras analisadas. Quatro entre 7 apresentaram teste presuntivo positivo para T.thioparus com elevada produção de ácido (Tabela 8.2). O pH final observado em duas amostras de 2,2 e 3,9, indica que existem microrganismos enxofre-oxidantes que podem estar envolvidos nos processos de oxidação de fontes inorgânicas de enxofre presentes no carste. A literatura evidencia que as reações redox do metabolismo microbiano estão diretamente associadas à gênese de cavernas. Espécies de Thiobacillus sp. são mencionadas como co-responsáveis da espeleogênese por ação do ácido sulfúrico liberado como produto final do metabolismo microbiano (Hose et. al., 2000).

TABELA 8.2 - PH DA AMOSTRA E DO MEIO DE CULTURA DE POSTGATE MODIFICADO PARA T.THIOPARUS.

\begin{tabular}{ccccccccc} 
Período de & \multicolumn{7}{c}{ amostras } \\
\cline { 2 - 9 } incubação (dias) & ba-06 & ba-07 & ba-08 & ba-09 & ba-11 & ba-14 & ba-15 \\
\hline 15 & 6,6 & 7,6 & 4,8 & 4,6 & 8,1 & 3,8 & 3,9 \\
21 & 6,9 & 7,1 & 3,9 & 3,4 & 7,3 & 2,2 & 3,7 \\
\hline
\end{tabular}

Comparando-se os resultados obtidos em condições de autotrofia observou-se para os mesmos pontos amostrados a confirmação da diminuição do valor do $\mathrm{pH}$ final do meio após 21 dias de incubação. As amostras do Cochó do Malheiro foram as que apresentaram menor $\mathrm{pH}$ do meio, diminuindo de 7,4 ( $\mathrm{pH}$ inicial do meio) para 2,2. A diminuição do $\mathrm{pH}$ do meio pode estar relacionada com a presença de bactérias 
enxofre-oxidantes capazes de utilizar a única fonte de energia disponivel no meio, o tiossulfato.

A pirita, para ser oxidada com eficiência, necessita de um agente catalizador, tendo em vista sua baixa reatividade em águas naturais (Moses et al, 1987). As bactérias oxidantes e as bactérias redutoras de sulfato, encontradas na área de estudo, por estabelecerem um ciclo (oxidação-redução), cumprem o papel de agentes aceleradoras do processo, condição esta que propicia a formação de ácido sulfúrico de forma contínua. 


\section{CAPÍTULO 9 - CONCLUSÕES E CONSIDERAÇÕES FINAIS}

O presente estudo teve por objetivo geral caracterizar a hidrogeoquímica associada ao sistema cárstico do Grupo Una, testando a hipótese da participação do ácido sulfúrico na circulação da água subterrânea. A caracterização hidroquímica das águas, indicou que os altos índices do ânion sulfato são anômalos quando comparados com outras áreas cársticas brasileiras. Foram assim estabelecidas fácies hidroquímicas e observou-se que em determinados ambientes de circulação da água subterrânea a concentração de sulfato é dominante em relação aos demais ions. Destacam-se neste quesito amostragens realizadas em águas subterrâneas profundas que percolam em rochas carbonáticas (fácies 3) e percolação vadosa (fácies 4), ambas com concentrações expressivas para o citado íon (até $747 \mathrm{mg} / \mathrm{L}$ ). Foi necessário responder: de onde vem o sulfato? Análises químicas das águas das chuvas indicam concentrações muito baixas de sais dissolvidos, inclusive sulfato, o mesmo ocorrendo com as águas de injeção alogência; os metarenitos do Grupo Chapada Diamantina, principal zona de recarga, e as rochas do Grupo Una não possuem minerais primários de sulfato predispostos à dissolução. Por outro lado, rochas do Grupo Una exibem significativo potencial metalogenético para sulfetos. Assim, mediante este quadro, a possibilidade para o fornecimento de enxofre, encontrado dissolvido em significativas concentrações nas águas das diferentes fácies, seria a partir da oxidação de sulfetos, principalmente pirita.

Os dados hidroquímicos foram tratados e os resultados da modelagem estequiométrica, baseada nas razões molares das principais reações químicas do carste, demonstram que a reação clássica de dissolução de rocha carbonática por ácido carbônico não é a única possível. Observou-se que a razão molar entre $\mathrm{Ca}^{2+}+\mathrm{Mg}^{2+} / \mathrm{HCO}_{3}{ }^{-}$, para as fácies hidroquímicas, não são compatíveis ao balanço estequiométrico para a reação de dissolução da rocha carbonático pelo ácido carbônico. A aplicação dos resultados hidroquímicos das fácies para a razões molares $\mathrm{Ca}^{2+}+\mathrm{Mg}^{2+} / \mathrm{HCO}_{3}{ }^{-}$e $\mathrm{Ca}^{2+}+\mathrm{Mg}^{2+} / \mathrm{SO}_{4}{ }^{2-}$ também não são compatíveis ao balanço estequiométrico para a reação entre rocha carbonática e ácido sulfúrico. Partindo destes resultados, observou-se que as citadas razões molares somente tornam-se compatíveis quando considera-se a reação entre rocha carbonática e uma ação simultânea entre os ácidos carbônico e sulfúrico. 
A associação entre os resultados hidroquímicos e o monitoramento hidrológico, durante um ano, demonstrou que o sistema cárstico estudado apresenta um fluxo de massa significativo, representado por 21274 t/ano de $S$ (sob a forma de sulfato) escoadas pelo sistema, na Bacia de Irecê, o que comprova tratar-se de um sistema ativo para a produção do íon sulfato.

A observação e identificação de depósitos secundários de gipsita ao longo do sistema evidenciaram que o a região estudada ressalta-se em relação a outras áreas do Brasil pela quantidade e variedade de ocorrências destes, predominando os espeleotemas na forma de crostas e agulhas de gipsita. A deposição destes minerais secundários de gipsita foi inserida no quadro evolutivo do sistema cárstico,durante o quaternário, onde o evento principal de deposição ocorreu associado ao rebaixamento gradativo do nível d'água após a fase de ampliação paragenética dos condutos.

Os valores de $\delta^{34} S$ de pirita disseminada na rocha carbonática estão incluídos na faixa de variação dos valores de $\delta^{34} S$ de sulfato precipitado da água subterrânea, condição que indica a oxidação de piritas como o processo responsável pela produção de sulfato em água.

Os valores de $\delta^{13} \mathrm{CHCO}_{3}$ - também sugerem que os processos de dissolução no sistema cárstico estudado correspondem a uma combinação entre ação dos ácidos sulfúrico e carbônico, pois os valores mais empobrecidos de $\delta^{13} \mathrm{CHCO}_{3}$ foram associados a reação da rocha com ácido carbônico enquanto que os relativamente mais enriquecidos foram vinculados à dissolução da rocha carbonática por ácido sulfúrico.

A presença de bactérias acidofílicas (Acidithiobacillus) e bactérias redutoras de sulfato na água subterrânea da área de estudo associada com os resultados hidroquímicos reforçam a tese da geração de ácido sulfúrico em ambiente freático profundo já que ambas têm o papel de catalizar as reações e proporcionar a manutenção da produção das soluções ácidas.

O presente estudo foi realizado na região centro-norte do estado da Bahia, pois apresenta características sui generis em relação às questões científicas do estudo de terrenos cársticos no Brasil. Por outro lado, esta escolha incorreu em dificuldades logísticas, tais como distância, freqüência de monitoramento, manutenção de equipamentos, entre outros, que não permitiram a obtenção de um grande conjunto de dados distribuídos ao longo do período de monitoramento. Mesmo assim, os resultados obtidos permitiram definir processos relacionados à dinâmica do sistema 
cárstico estudado, cumprindo os objetivos estabelecidos para esta pesquisa. Com base nos resultados é possível delinear necessidades de pesquisas futuras no sentido de ampliar o entendimento do sistema. A título de exemplo, no que diz respeito a hidrologia, pesquisas poderão ser concentradas para definir com precisão os fluxos da água subterrânea, bem como o delineamento do divisor de águas na Bacia de Irecê. Com relação à contribuição do ácido sulfúrico na dinâmica corrosiva do carste estudado, um detalhamento dos estudos isotópicos faz-se também necessário para tentar quantificar a participação dos diferentes ácidos envolvidos. 


\section{REFERÊNCIAS BIBLIOGRÁFICAS}

AGÊNCIA NACIONAL DE ÁGUAS -ANA (2003) disponivel em www.ana.gov.br

APPELO,C.A.J \& POSTMA,D (1993) - Geochenistry, Groundwater and Pollution. Ed Balkema, Rotterdam, Netherlands, 536p.

AULER, A.S. (1996) Evidências de Dissolução por Ácido Sulfúrico na Espeleogênese do Grupo Una - Bahia. In : SIMPÓSIO DE GEOLOGIA DE MINAS GERAIS,8 ,Belo Horizonte, 1996. Anais-Boletim 13. SBG/NMG. p93-94.

AULER,A.S.(1999) Karst Evolution and Paleoclimate of Eastern Brazil. Bristol, UK. (PhD thesis, Dept of Geography/ University of Bristol)

BACK, W. (1960) Origin of hydrochemical facies of ground water in the Atlantic Coastal Plain. In: INTERNATIONAL GEOLOGICAL CONGRESS, 21., Copenhagen, 1960; Proceedings. Copenhagen, Det Berlingske. p. 87-95.

BALDI, F.; CLARK, T; POLLACK S.S.; OLSON; G.J. (1992) Leaching of pyrites of various recativities by Thiobacillus ferrooxidans. Appl. Environm. Microbiol. 58, 1853-56.

BALL,T.K \& JONES, J.C. (1990) Speleogenesis in the Limestone Outcrop North of the South Wales Coalfield : The Role of Micro-organisms in the Oxidation of sulphides and Hydrocarbons. Cave Science, 17(1): p3-9.

BASTOS, L.R. \& PEIXOTO, H. (coord) (2004) Projeto: Modelização da dinâmica hidrológica e instrumentos para a gestão do sistema aqüifero-rio das bacias hidrográficas dos rios Verde e Jacaré - região semi-árida do Estado da Bahia. Relatório Técnico Final do Convênio SRH / UFBA / FAPEX / NEHMA / POSGEMA / DEA.

BERTOLANI, M.;GARUTI, G.; ROSSI, A.; BERTOLANI, M. D., (1976), Motivi di interesse mineralógico-petrografico nel complesso carsico Grotta Grande Del Vento-Grotta del Fiume (Genga, Ancona): Grotte d'ttalia, ser. 4, v. 6, p. 109-144.

BISCHOFF, J.L.; JULIÁ, R. ; SHANKS, W.C ; ROSENBAUER, R.J. (1994) Karstification Without Carbonic Acid : Bedrock Dissolution by gypsum-driven dedolomitization. Geology, 22: p995-998.

BÖGLI, A. (1980) Karst Hidrology and Physical Speleology. Berlin. Springer Verlag. 292p.

CABRAL, F.C.F. (1978) O Uso dos Isótopos Naturais de Carbono no Estudo das Águas Subterrâneas do Calcário Bambuí - Região Central da Bahia. Salvador (dissertação de mestrado - Instituto de Geociências / UFBA) 
CALANDRI, G. ( 1979), I cristalli di gesso in grotte calcaree: Soc. Espeleol. Ital., v.2, p. 45-97.

CALANDRI, G. (1980) The deposition of gypsum in caves: Caving Int., no. 9, p. 44-46.

CANFIELD, D.E \& THAMDRUP, B (1994) The production of 34S-depleted sulfide during bacterial disproportionation of elemental sulfur. Science 266.

CBPM - Companhia Baiana de Pesquisa Mineral (1998) Projeto Fosfato de Irecê. Salvador-BA. Relatório Interno.

CERB - Companhia de Engenharia Rural da Bahia (2002) - Base de Dados de poços da bacia de Irecê. Salvador-BA, 1 disquete.

CETESB (COMPANHIA DE TECNOLOGIA DE SANEAMENTO AMBIENTAL). (1991) Thiobacillus- Determinação do número mais provável pela técnica dos túbos múltiplos. São Paulo (L5.217).

CETESB (Companhia de Tecnologia e Saneamento Ambiental). (1988) Guia de Orientação e preservação de amostras de água. São Paulo.

CLARK, I.D. \& FRITZ, P. (1997) Environmental isotopes in hydrogeology. CRC Press / Lewis Publishersd. Boca Raton, FL. 328p.

COSTA, L. A . M. \& INDA, H.A. V. (1982) O aulacógeno do Espinhaço. Ciências da Terra, 2: 13-18.

CRAIG, H. (1953) The Geochemistry of the stable carbon isotopes. Geochimica Cosmochimica Acta 3: 53-92

CRUZ JR, F.W. (1998) Aspectos Geomorfológicos e Geoespeleologia do Carste da Região de Iraquara, Centro Norte da Chapada Diamantina, Estado da Bahia. São Paulo-SP.(Dissertação de mestrado - Instituto de Geociências/USP)

DANDEFER-FILHO, A. (1990) Análise Estrutural Descritiva e Cinemática do Supergrupo Espinhaço na Região da Chapada Diamantina, Ba. Ouro PretoMG(dissertação de mestrado - Universidade Federal de Ouro Preto)

DARDENNE,M.A. (1978) Síntese Sobre a Estratigrafia do Grupo Bambuí no Brasil Central. In : CONGRESSO BRASILEIRO DE GEOLOGIA, 3O, Recife, 1978. Anais. SBG. 2:p597-610.

DOMENICO,P.A. \& SCHWARTZ, F.W. (1990) Physical and Chemical Hydrogeology. John Wiley \& Sons. New York,USA.824p.

DOMINGUEZ, J.M.L (1993) As coberturas do Cráton do São Francisco: uma abordagem do ponto de vista da análise de bacias. In: DOMINGUEZ, J.M.L; MISI, A. eds. O Cráton do São Francisco, SBG BA-SE/SGM/CNPq. Salvador, BA, Brazil, p.137-159. 
DRAKE, J.J. \& HARMOM, R.S. (1973) Hydrochemical environments of carbonate terrains. Water Resources Research, 9(4):949-957.

EATON,A.D.; FRANSON,M.A.H.; CLESCEN,L.S.; GREENBERG,A.E. (eds) (1995) Standard Methods for Examination of Water and Waste water. $19^{\text {th }}$ ed. Washington,D.C.,USA. American Public Health Association. 1268p.

EGEMEIER, S.J. (1981) Cavern Development by thermal Water. NSS Bulletin. 43: p3151.

ELSHAHED, M.S.; SENKO, J.M.; NAJAR, F.Z.; KENTON, S.M.; ROE, B.A.; DEWERS, T.A.; SPEAR, J.R.; KRUMHOLZ, L.R. (2003) Bacterial diversity and sulfur cycling in a mesophilic sulfide-rich spring. Applied and Environmental Microbiology 69 (9), 5609-5621.

ENGEL, A. S. (2000) Microbially-enhanced weathering in subsarface habitats: súlfuroxidizing bacteria and the cave environment.-. from Proceedings of the Friends of Karst Meeting. Cluj. Romenia - B. Onac and. Tamas (ed). Karst Studies and Problemas: 2000 and Beyond, p130-134.

ENGEL, A.S.; LEE, N.; PORTER, M.L.; STERN, L.A.; BENNETT, P.C.; WAGNER, M.(2003) Filamentous "Epsilonproteobacteria" dominate microbial mats from sulfidic cave springs. Appl. Environm. Microbiol. 69 (9), 5503-5511.

ENGEL, A.S.; POTTER, M.L.; KINKLE, B.K.; KANE, T.C. (2001)Ecological assessment and geological significance of microbial communities from Cesspool Cave, Virginia. Geomicrobiol. J. 18, $259-274$.

FAURE,G. (1986) Principles of Isotope Geology. 2rd Ed. John Wiley \& Sons. New York. 589p.

FERRARI,J.A. (1990) Interpretação de Feições Cársticas na Região de Iraquara-Bahia. Salvador.(Dissertação de mestrado - Depto de Geografia /UFBA)

FORD,D.C. \& WILLIAMS, P.W. (1989) Karst Geomorphology and Hidrology. London . Chapman \& Hall. 601p.

FORTI, P. (1988) The Role of Sulfide-sulfate Reaction in Speleogenesis. Instituto Italiano di Speleologia - Bologna-Italy. Tech.Report.11p.

GARCEZ, L.N. (1967) Hidrologia. Ed. Edgarg Blücher / EDUSP. São Paulo-SP. 249p.

GARRELS, R.M. \& CHRIST, C.L (1965) Solutions, minerals and equilibria. London, Harper \& Row. 450p.

GOMES, F.V.M. (1978) Aplicação de Isótopos de Urânio como Traçadores de Água Subetrrânea do Bambuí - Bahia. Salvador. (dissertação de mestrado - Instituto de Geociências / UFBA) 
GRAGNOLINO, G. \& TUOVINEN, O. H. (1984) The role of sulphate-reducing and shulphur-oxidizing bacteria in the localized corrosion of iron-base alloys $-a$ review. Inst. Biodeterior., 20 (1): 9-26.

GUERRA, A.M. (1986) Processos de Carstificação e Hidrogeologia do Grupo Bambuí na Região de Irecê , Bahia. São Paulo.(Tese de Doutoramento - Instituto de Geociências/USP)

HARGREAVES, G.H. (1994) Defining and Using reference evapotranspiration. Journal of Irrigation and drainage Engineering. New York, 120:6:p1132-1133.

HILL,C \& FORTI, P. (1997) Cave Minerals of the World. 2nd Ed. National Speleological Society, Inc. Alabama-USA.439p.

HILL,C. (1987) Geology of Carlsbad Cavern and other Caves in the Guadalupe Mountains, New Mexico and Texas. New Mexico Institute of Mining and Tech. Bulletin, 117.

HILL,C. (1990) Sulfuric Acid Speleogenesis of Carlsbad Cavern and Its Relationship to Hydrocarbons, Delaware Basin, New Mexico and Texas. The American Association of Petroleum Geologist Bulletin. 74(11):p1685-1694.

HILL,C. (1995) Sulfur Redox reactions: Hydrocarbons, Native Sulfur, Mississippi Valey - Type Deposits, and Sulfuric acid Karst in the Delaware Basin, New Mexico and Texas. Environmental Geology. 25(1): p16-23.

HOEFS, J. (1997) Stable Isotope Geochemistry. $4^{\text {th }}$ ed. Berlin, Germany. Springer Verlag. 201p.

HOSE, L.D. \& PISAROWICZ, J.A. (1999) Cueva de Villa Luz, Tabasco, México: reconnaissance study of an active sulphur spring cave and ecosystem. Journal of Cave and Karst Studies. 61(1): 13-21.

HOSE, L. D., PALMER, A. N , PALMER, M. V., NORTHUP, D. E., BOSTON, P. J. , DUCHENE, H. R. (2000) Microbiology and geochemistry in a hydrogen-sulphiderich karst environment. Chemical Geology 169: 399-423.

HUBBARD, D.; HERMAM, J.; BELL, P. (1990) Speleogenesis in a travertine scarp: Observations of sulfide oxidization in the subsurface, in Herman, J., and Hubbard, D., (eds.), Travertine-marl: Stream Deposits in Virginia. Virginia Division of Mineral Resources, Pub. 101. Charlottesville, VA: Dept. of mines, Minerals, and Energy, Division of Mineral Resources: p. 177-184.

IBGE - Instituto Brasileiro de Geografia e Estatística (1975) Folha Brejão da Caatinga SC.24-N-I, escala 1:100.000

IBGE - Instituto Brasileiro de Geografia e Estatística (1975) Folha Seabra - SD.24-V-AI, escala 1:100.000. 
IBGE - Instituto Brasileiro de Geografia e Estatística (1975) Folha Canarana - SC.24Y-C-IV, escala 1:100.000

INDA,H.A.V \& BARBOSA,J.F. (1978) Mapa Geológico do Estado da Bahia 1 : 1000000. Projeto Radam Brasil. Texto Explicativo: p137. DNPM/MME.

INPE - INSTITUTO NACIONAL DE PESQUISAS ESPACIAIS - (2003) Centro de Previsão de Tempo e Estudos Climáticos CPTEC. disponível em www.cptec.inpe.br

JUDE, L. (1972) Les anthodites des monts de Rodna: Trav. Inst. Espél. "É . Racovita," v. 11, p. 343-347.

KARMANN, I. \& SANCHEZ, L.E. (1979) Disribuição das rochas carbonáticas e províncias espeleológicas do Brasil. Espeleo-Tema. 13:105-167.

KARMANN, I. (1994) Evolução e Dinâmica Atual do Sistema Cárstico do Alto Vale do Rio Ribeira de Iguape, Sudeste do Estado de São Paulo. São Paulo. (Tese de Doutoramento, Instituto de Geociências/USP)

KROTHE,N.C \& LIBRA,R.D. (1983) Sulfur Isotopes and Hidrochemical Variations in Spring Waters of Souther Indiana, USA. Journal of Hydrology. 61: p261-283.

KROUSE, H.R. (1980) Sulfur isotopes in our environment. In: Fritz,P. \& Fontes, J.Ch (eds) (1980) Handbook of Environmental Isotope Geochemistry. Elsevier, Amsterdã. Volume 1. p435-471.

KUENEN, L. G., L. A. ROBERTSON, and O. H. TUOVINEN. (1992). The genera Thiobacillus, Thiomicrospira and Thiosphaera, p. 2638-2657. In A. Ballows, H. G. Truper, M. Dworkin, W. Harder, and K. H. Schwifer (ed.), The Prokaryotes, vol. 3. Springer Verlag, New York, N. Y.

KYLE, J.R. \& MISI, A. (1997) . Origin of Zn-Pb-Ag sulfide mineralization within Upper Proterozoic phosphate-rich carbonate strata, Irecê Basin, Bahia, Brazil, International Geology Review 39: 383-399.

LANGMUIR,D. (1971) The Geochemistry of Some Carbonate Groundwaters in Central Pennsylvania. Geochimica Cosmochimica Acta,35(10):p1023-1045.

LAUREANO,F.V. (1998) O Registro Sedimentar Clástico Associado aos Sistemas de Cavernas Lapa Doce e Torrinha, Município de Iraquara, Chapada Diamantina, Estado da Bahia. São Paulo-SP(Dissertação de mestrado - Instituto de Geociências/USP)

MASCARENHAS, J.C.; PEDREIRA, A.J.; MISI, A.; MOTTA, A.C.; SÁ, J.H.S. (1984) Província São Francisco. In : ALMEIDA,F.F.M. ; HASUI,Y. ed. (1984) O Pré Cambriano do Brasil. São Paulo, Ed. Edgard Blücher, São Paulo.p46-122 
MILANOVIC,P.T. (1981) Karst Hidrogeology. Littleton Water Resources Publication. $434 \mathrm{p}$.

MISI, A (1978) Ciclos de sedimentação e mineralizações de Pb-Zn nas seqüências Bambuí (Supergrupo São Francisco). Estado da Bahia. In: Congresso Bras. de Geologia, 30, Soc. Brasileira de Geologia, Recife, Anais, v.4 p.2548-2561.

MISI, A. \& VEIZER,J. (1998) Neoproterozoic Carbonate Sequences of the Una Group, Irecê Basin, Brazil: Chemostratigraphy, age and correlations. Precambrian Research 89: 87-100.

MISI, A. (1979) O Grupo Bambuí no estado da Bahia. In: Geologia e Recursos Minerais da Estado da Bahia ( H. A.V. Inda ed.) SME, CPM, Salvador, pp. 120-154.

MISI,A \& SILVA,M.G. (1996) Chapada Diamantina Oriental - Bahia - Geologia e Depósitos Minerais. Série Roteiros Geológicos. Editado por Secretaria da Indústria, Comércio e Mineração / Superintendência de Geologia e Recursos Minerais-SGM. Salvador, Bahia.194p.

MISI,A. \& KYLE, J.R. (1994) Upper Proterozoic Carbonate Stratigraphy, Diagenesis, Stromatolitic Phosphorite Formation, Irecê Basin-Bahia-Brazil. Journal of Sedimentary Research. A64(2):p299-310.

MISI,A. \& SOUTO,P. (1975) Controle Estratigráfico das Mineralizações de Chumbo, Zinco, Flúor e Bário do Grupo Bambui- Parte Leste da Chapada de Irecê(Bahia). Revista Brasileira de Geociências. 5(1):p30-45.

MOREHOUSE, D.A. (1968) Cave development via the sulfuric acid reaction. National Speleological Society Bulletin. 30:1-10

MOSES, C.O.; NORDSTROM, D.K.; HERMAM, J.S.; MILS, A.L. (1987) Aqueous pyrite oxidation by dissolved oxygen and by ferric iron. Geochimica et Cosmochimica Acta. 51:1561-1571.

NAKAI,N. \& JANSEN,M.L. (1964) Kinetic isotope effect in the oxidation and reduction of sulfur. Geochimica et Cosmochimica Acta. 28:1893-1912.

NEGRÃO, F.I. (1987) Caracterização Hidrogeoquímica e Vulnerabilidade do Sistema Hidrogeológico Cárstico da Região de Irecê, Bahia. São Paulo.(Dissertação de mestrado - Instituto de Geociências/USP).

ONAC, P. B. (1991) New data on some gypsum speleothems in the Vîntului (Padurea Craiului Mountains) and Rastoce (Somesan Plateau) caves: Trav. Inst. Spéol. "É. Racovita," v.30 p. 189-193.

PALMER, A.N. (1991) Origin and Morphology of Limestone Caves. Geological Society Of America Bulletin. 103:p1-21. 
PANKHURST, E. S..(1964) Polarografic evidence of the production of polythionates during the bacterial oxidation of thiossulfate. J. Gen Microbiol., 34:427-439.

PARKER, C. D. \& PRIST, J. (1953)The oxidation of inorganic compounds of sulphur by various sulphur bacteria. J. Gen Microbiol.8:344-364.

PEDREIRA-DA-SILVA, A .J. (1994) O Supergrupo Espinhaço na Chapada Diamantina Centro Oriental, Bahia: Sedimentologia, estratigrafia e tectônica. São Paulo-SP (Tese de Doutorado. Instituto de Geociências/USP).

PERNA , G \& POZZI, R. (1959), Osservazioni su Alcuni Fenomeni concrezionari della Grotta Del Fiume (Ancona):Rass. Speleol. Ital.,v.11, no 1,p. 13-17

POHL, E. R \& WHITE, W.B., (1965) Sulfate minerals: their origin in the Central Kentucky Karst : Am. Mineralogist. v. 50, p. 1462-1465.

POSTGATE, J.R. (1979) The Sulphate-Reducing Bacteria. Cambridge University Press. $145 p$.

SAKAMOTO, I.K. (1996) Comportamento do Consórcio Microbiano Existente Em Um Lodo Granulado Anaeróbio Metanogênico Submetido A Adições Crescentes de Sulfato. Dissertação de Mestrado. Escola de Engenharia de São Carlos, 157p.

SHIRAKAWA, M.A. (1994) Estudo da biodeterioração do concreto por Thiobacillus. São Paulo, . 121 p. (Dissertação de mestrado- Universidade de São Paulo)

SIQUEIRA, A.F. (1978) O Uso dos Dados Isotópicos e Químicos como Indicadores de Origem das Águas e Sais Dissolvidos no Aqüifero Calcário Bambuí, Irecê, Bahia, Brasil. Salvador (dissertação de mestrado - Instituto de Geociências / UFBA)

SOUZA, S.L.; BRITO, P.C.R.; SILVA, R.W.S.(1993) Estratigrafia, sedimentologia e recursos minerais da Formação Salitre na Bacia do Irecê, Bahia. Série Arquivos Abertos, 2. 34p. Companhia Baiana de Pesquisa Mineral, Salvador.

STUMM,W \& MORGAN, J.J. (1995) Aquatic Chemistry : An Introdution Emphasizing Chemical Equilibria in Natural Waters. Wiley, New York,NY.780p.

SULTANOV, Z.S. (1975) Genesis of Karst caverns of southern Fergana (Kirgizstan): USSR Geogr. Soc., Moscow, p. 123-126.

TAVARES, G. A. (1983) Estudos Isotópicos e Hidroquímicos em Águas da bacia do Rio Verde. Salvador-BA (dissertação de mestrado - Instituto de Geociências/UFBA)

TORAN, L. \& HARRIS, R.F. (1989) Interpretation of sulfur and oxygen isotopes in biological and abioogical sulfide oxidation. Geochimica et Cosmochimica Acta. 53: p2341-2348. 
TORTORA G J, FUNKE B R, CASE C L. Microbiologia. $6^{\text {a. }}$ ed. Rio de Janeiro: Artmed Editora, 2000.

TUOVINEN O.H.; KELLY, D.P. (1973) Studies on the growth of thiobacillus ferooxidans. Arch. Mikrobiol. 88, 285-298.

VAN EVERDINGEN R.O. ; SHAKUR,M.A. ; KROUSE, H.R. (1987) Role of Corrosion by $\mathrm{H}_{2} \mathrm{SO}_{4}$ Fallout in Cave Development in a Travertine Deposit - evidence from sulfur and oxigen isotopes. Chemical Geology. 49:p205-211.

VIANNA JR, O. (2003) Hidroquímica, Hidrologia e Geoquímica Isotópica (O e H) da Fácies de Percolação Vadosa Autogênica, Caverna Santana, Município de Iporanga, Estado de São Paulo. São Paulo-SP (dissertação de mestrado Instituto de Geociências/USP)

VISHNIAC, W. \& SANTER, M. (1957) The Thiobacilli. Bacteriol. Rev., 21:195-213,.

VLASCEANU, L.; POPA, R.; KINKLE, B.K. (1997) Characterization of Thiobacillus thioparus LV43 and its distribution in a chemoautotrophically based groundwater ecosystem. Applied Environmental Microbiology. (63):3123-3127

VOGEL, A.I. (1992) Análise Quimica Quantitativa. (Horácio Macedo, trad). Livros Técnicos e Científicos Editora. São Paulo. 712p.

WHITE, W.B. (1988) Geomorphology and Hydrology of Karst Terrains. New York. Oxford University Press. 464p.

WORTHINGTON, S.R.H \& FORD, D.C. (1995) High Sulfate Concentrations in Limestone Springs : An Important Factor in Conduit Initiation. Environmental Geology. 25(1) p9-15.

WORTHINGTON, S.R.H. (1991) Karst Hidrogeology of the Canadian Rock Mountains. Hamilton, Canada. ( PhD thesis, Dept of Geograph/Mac Master University)

YONGE, C.J. \& KROUSE,H.R. ( 1987) The Origin of Sulphates in Castheguard Cave, Columbia, Icefields-Canada. Chemical Geology (Isotope Geosciences Series ) 65: $\mathrm{p} 427-433$.

YOSHIMURA, K ; NAKAO,S. ; NOTO,M. ; INOKURA,Y. ; URATA,K. CHEN,M. \& LIN, P.W (2001) Geochemical and stable isotopes studies on natural water in the Taroko Gorge área, Taiwan - chemical weathering of carbonate rocks by deep source $\mathrm{CO}_{2}$ and sulfuric acid. Chemical Geology 177: p415-430.

YU, J.Y.; McGENTY, T.J.; COLEMAN, M.L. (2001) Solution chemistry during the lag phase and exponential phase of pyrite oxidation by Thiobacillus ferrooxidans.

Chemical Geology 175, 307-317. 